\title{
SCIENCE FROM AN EASY CHAIR
}

SIR RAY LANKESTER 


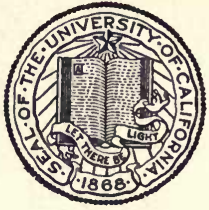

THE LIBRARY

OF

THE UNIVERSITY

OF CALIFORNIA RIVERSIDE 


$\because$ 


\section{SCIENCE FROM AN EASY CHAIR}


BY THE SAME AUTHOR

Extinct Animals

The Kingdom of Man

From an Easy Chair 

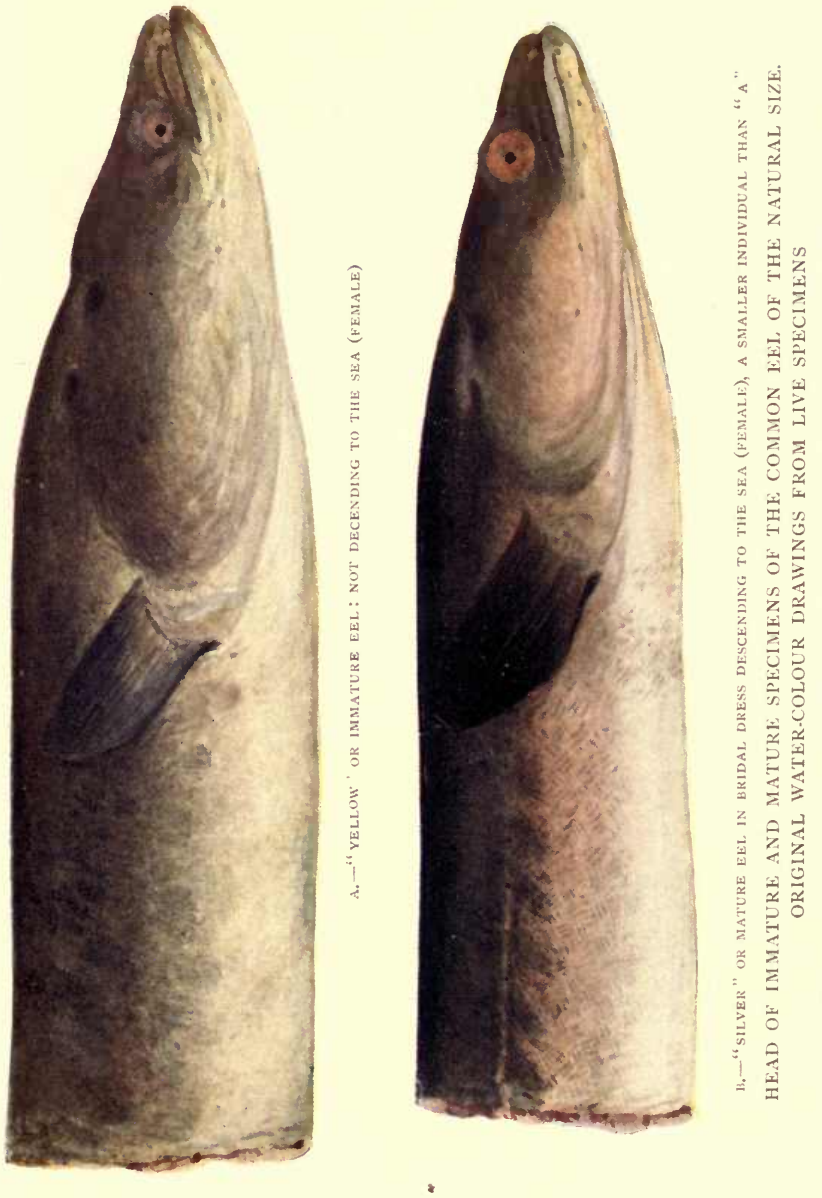


\title{
SCIENCE FROM AN
}

\section{EASY CHAIR}

\author{
BY \\ SIR RAY LANKESTER \\ K.C.B., F.R.S.
}

WITH EIGHTY-FOUR ILLUSTRATIONS

SEVENTH EDITION

METHUEN \& CO. LTD.

36 ESSEX STREET W.C.

LONDON 


\section{PREF A CE}

THIS volume is a collection of some of the papers 1 which I have contributed to the Daily Telegraph during the years 1908-1909, under the title "Science from an Easy Chair." I have revised and corrected the letterpress, and have added some illustrations. A smaller volume containing earlier papers was published by Messrs. Constable in 1908, with the title From an Easy Chair. It is my intention now to produce additional volumes (under the title "Easy Chair Series") as their constituent articles accumulate, and I hope to be able to publish a second and a third instalment at no distant date.

I should like to draw the special attention of the reader to the Frontispiece (Plate I.), which is very beautifully executed, and is, I believe, the first coloured drawing yet published showing the difference between the adult "silver" eel and the more abundant immature "yellow" eel-sometimes called the "frogmouthed eel." The original drawings were prepared for me through the kindness of Dr. Petersen, of Copenhagen, who is the discoverer of many interesting facts about the 
common eel, and is director of the Danish Biological Laboratory.

I also wish to draw the attention of any one who is kind enough to look at this preface to one or two more of my illustrations, because they are, I think, of exceptional interest, and should be looked at, at once, before a decision not to read the book is made. These are the prehistoric engraving of a horse's head, with rope-bridle in place, on page $8 \mathrm{I}$; the drawings of the leaves of the American Poison-vine and of the Virginian Creeper on page 95 ; of the nettle-sting on page 113 ; of the Dragon of the Hesperides on page 122 ; of the big tadpoles on page 217 ; of the jumping bean on page 298 , and its moth on page $30 \mathrm{r}$; of the ant milking a greenfly for its honey-dew on page 324 ; and lastly, the accurate drawing on page 370 of the most ancient human skull yet discovered, and the other drawings of skulls (all to the scale of one-third the actual length), and those of prehistoric weapons and carvings which follow it. These drawings have been made from original scientific memoirs, or in some cases from actual specimens, for the present volume.

E. RAY LANKESTER

February 1910 


\section{GONTENTS}

I. Science and Practice . . . . I

II. University Training . . . 6

III. DARWIN'S THEORY • $\quad$ - $\quad$ - 12

IV. DARWIN'S DISCOVERIES • • . 18

V. Darwin's Theory Unshaken . . 27

VI. Metchnikoff and Tolstoi . • • 38

ViI. The Land of Azure Blue • • • . 46

VIII. Fresh-WATER Jelly-Fishes . - . 58

IX. The Story of the Common Eel . • • 65

X. Modern Horses and their Ancestors . • 77

XI. A Rival of the Fabled Upas Tree • • 9I

XII. Poisons and Stings of Plants and Animals . 100

XIII. The Dragon: A Fancy or a FaCt . . II4

XIV. OVSTERS .

XV. Maternal Care and Molluscs . . . 143

XVI. The Heart's Beat . . . . . 147

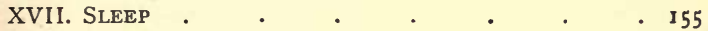

XVIII. The Universal Structure of Living Things • 170

XIX. Protoplasm, Life and Death . . . 180

XX. Chemistry aNd Protoplasm . $\quad$. 187

XXI. The Simplest Living Things • • . 193

XXII. TADPOlES AND FrogS . • • 209

XXIII. About the Stars . • . • 220

XXIV. COMETS . . . . . . . . 227

XXV. About Cholera $\quad$ - $\quad$ - $\quad$ - 237

XXVI. Sea-Breezes, Mountain Air, AND Ozone 251

XXVII. OXYgen Gas for Athletes AND Others . 258 
XXVIII. Sparrows, Trout, and Selective Breeding . 266 XXIX. The FEeble-MiNded XXX. Death-Rates XXXI. GOSSAMER .

XXXII. The Jumping Bean XXXIII. Protective Colouring in Animals XXXIV. HOP-BLIGHT . XXXV. Green-Flies, Plant-Lice, and Partheno-

XXXVI. The Deadly Phylloxera - . 334 XXXVII. Clothes Moths . $\quad$. $\quad$ • 339 XXXVIII. STONE AND WOOD BORERS . • 346 XXXIX. Christmas Fare - • • • • 356 XL. The ORIGIN OF OPIUM . $\quad$ • $\quad$ • 363 XLi. The Most Ancient Men . . . . $37 \mathrm{I}$ Xlil. The Cave-Men's Skulls . • • . 39 I XLiII. More About the Neander MeN • • 402 INDEX 


\section{LIST OF ILLUSTRATIONS}

\section{DIAGRAMS IN THE TEXT}

YIG.

I. The Little Green Tree-Frog or "Rainette" of THE RIVIERA (HYLA ARBOREA) • • $5 \mathrm{I}$

2. The Common Jelly-Fish (AURELIA AURITA) • 59

3. THE FRESH-WATER JELLY-FiSH (LIMNOCODIUM) - 60

4. FOUR JELLY-Fish-PRODUCING POLYPS ADHERING TO A

ROOT-FIBRE OF A WATER-PLANT • • • 6I

5. The AFrican Fresh-WATER JELLY-Fish (IIMNOCNIDA) 62

6. Young Stages of the Common Eel . . 72

7. DRAWING OF AN IVORY Carving OF a Female

HEAD . . . . . . . 80

8. Drawing of a Fully Rounded Carving in ReiNDEER'S ANtler of the Head OF a Neighing

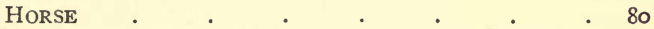

9. Drawing of a Flat Carving in Shoulder-Bone of a Horse's Head, SHOWING Twisted ROPE-BRIDLE AND TRAPPINGS • . $\quad$. $\quad$. $\quad$. 81

10. Fore-Foot of the Horse-Ancestor, Hipparion - 84 I1. SKulls OF Horses AND OF DEER - • 86

12. FORE AND HIND LEgS OF HORSE AND ASS • 88

13. Diagram of the Under Surface of the Foot in THE DOG, TAPIR, AND HORSE • • • • $\quad$ • 89

14. DRAWINGS OF THE LEAVES OF THE COMMON QUINQUEFOLIATE VIRGINIAN CREEPER, OF THE ADHERENT "AMPElopsis Veitchil," AND OF the POISON-Vine (RHUS TOXICODENDRON). 
FIG.

15. DRAWING FROM LIFE OF THE DESERT SCORPION (BUTHUS AUSTRALIS, LIN.), FROM BISKRA, NORTH AFRICA

I5 Bis. Highly Magnified DRawing of a Stinging Hair OF THE COMMON NETTLE

16. The Heraldic Dragon

17. The HERALDic GRIFFin

18. Hercules destroying the Hydra

19. The Heraldic WYvern .

20. The Heraldic Basilisk, also called the AmPHYSIAN COCKATRICE $\quad$. . . . 117

21. The Chinese Imperial Dragon . . . . I2I

22. A Flying SNake with Two Pairs of Wings . - I2I 23. The "Dragon" Guarding the Tree in the Garden

OF THE HESPERIDES • . • • . . 122

24. A Votive Tablet • . . . . . . 124

25. Ancient Roman Painting of a so-Called Marine

SERPENT . . . . . . . . 124

26. Egyptian Four-Winged SERPENT • • 125

27. Two-Winged Serpent $\quad$. $\quad$. $\quad$. 125

28. An Oyster with the Right-Side Shell Removed - izo

29. Part of a Row of the Lashing Hairs or "Cilia"

WHICH COVER THE GILLS OF THE OYSTER . . I3I

30. The ANIMAL OF AN OYSTER REMOVED FROM THE

SHELl . . . . . . . 132

31. The EgGS OF THE Oyster

32. The Sperms or Spermatozoa of a Ripe Oyster • 134

33. Development of the EgG OF the Common Oyster. I 35

34. Free-SWIMming Young OYSTER OR OYSTER-LARVA • 136

35. YOUNG OF THE POND-MUSSEL AFTER ESCAPING FROM

the Maternal Gill-Pouch • . . . 145

36. Simple "Cells," consisting of Naked Protoplasm,

Changing Shape and taking in Solid Food PaRTICLES

37. Cells forming Tissues 


\section{LIST OF ILLUSTRATIONS}

FIG.

38. Copy of Part of Robert Hook's Drawing of a Magnified Piece of CORK . . . . 173 39. A Piece of Cartillage . . . . . 174 40. Three Kinds of Cells • • • • • 175 41. Two Specimens of a Bell-Animalcule (Vorticella) 196 42. Six Successive Stages in the Division of A "Celll" 20 I 43. Stages in the Growth From the EgG of the COMMON FROG . 44. Outline Drawings of Three European Tadpoles 217 45. The Comet shown in the Bayeux Tapestry. 232 46. The Cholera Spirillum, or Comma-Bacillus of КOCH . . . . . . . . 241

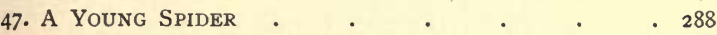
48. View of the Lower Surface of the Head and Body of a Large Burmese SPIDER . • . 290 49. Section through the Body of a Spider to show The Spinning Organs . . . . . 29I

50. One of the Two Middle Spinnerets of the ComMON GARDEN SPIDER (EPEIRA DIADEMA) • . 292 51. The Common Garden Spider, correctly Calied THE White-Cross SPIDER (EPEIRA DIADEMA) • 293 52. ON THE Right Two Jumping Beans: ON THE Left THE CATERPIllar Removed FROM THE JUMPING BEAN

53. The Caterpillar of the Moth (CARpocapsa salTITANS) REMOVED FROM THE JUMPING BEAN • 300 54. THE MOTH (CARPOCAPSA SALTITANS) • • • 301 55. Early Winged Female Hop-Louse • • • 316 56. Male Hop-Louse . . . • . 317 57. Ordinary Wingless Female Hop-Louse • • 318 58. FOUNDRESS OR STOCK-MOTHER OF THE Hop-Louse • 323 59. Side View of Winged Viviparous Female of the

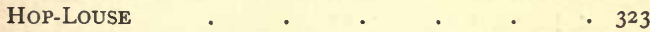
60. An Ant "Milking" a "Plant-Louse" or "GreenFLY" FOR HONEY-DEW . 
FIG.

6i. Single EgG-Tube or Ovarian Tube of an Insect - 329

62. The Death-Watch Beetle (Xestobium tessel-

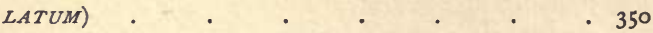

63. The Silver-FiSh INSECT (LEPISMA SACCHARINA) • 353

64. The Book-Louse, or Atropos diVINATORIA • . 354

65. The Human Skull from the Chapelle-aux-Saints 370

66. An Unpolished but Beautifully Chipped Flint KNIFe of The Neolithic Age . . . 374

67. A Polished Flint Axe-head of the Neolithic Age 375

68. Harpoons of the Paleolithic Period • . 379

69. A Piece of Mammoth Ivory Carved with Spirals AND SCROLLS

70. Carving on an Antler of a Group of Three Red DEer AND Four Fishes . . . . $38 \mathrm{I}$

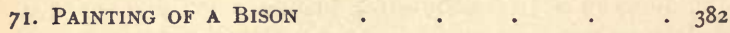

72. BACK AND FRONT View of a Flint IMPLEMENT OF THE MOUSTIER TYPE

73. Flint Pick from the Lower Pleistocene of the Thames Valley . • • . • • 387

74. A Rough TyPe OF Flint IMPLEMENT FROM THE Lower Pleistocene of the Somme Valley • 388

75. A Profile and a Front View of the Skull and LOWer Jaw of a Man OF the Cromagnard Race OR REINDEER MEN

76. THREe Views OF THE SKULL-TOP FROM NEAR DUSSELDORF ON THE RHINE, KNOWN AS THE NEANDERTHAL SKULL

77. The Gibraltar Skull from a Cave in Gibraltar . 392 78. The Skull-Top of the Primitive Kind of MaN from Pleistocene Sands in Java, called PithecANTHROPUS

79. DRAwing OF THE Left Side OF The LOWER JAW OF A Modern European.

80. Outline of the Skull of the Neander Man From the Chapelle-AUX-Saints 


\section{LIST OF ILLUSTRATIONS}

81. The Skull of a Male Chimpanzee

PAGR

82. The Heidelberg JaW

\section{PLATES}

I. ImMature and Mature Specimens of the Common Eel of the Natural Size. . Frontispiece II. Real Dragons. The Extinct Flying Reptiles KNown as Pterodactyles . . Facing $p$. 118 



\section{SCIENCE FROM AN EASY CHAIR}

\section{I \\ SCIENCE AND PRACTICE}

THE delight which is experienced by those who discover new things in the various branches of science is, no doubt, very great. To reveal to other men processes, properties, existences in the natural world hitherto unsuspected, or, if suspected, yet eluding the grasp of man, is to do something which gives to him who does it a sense that he is of value in the worlda sense which will uphold him and enable him to endure adversity, and even persecution, with equanimity. But there is, perhaps, a greater and more vivid satisfaction for those who do or make great and splendid things which all men can see, and for which all men are grateful. The great artist-poet, painter, builder, or musician-has this satisfaction, and so also has the man who, by a combination of personal energy and clearness of intellectual vision, applies scientific knowledge to the accomplishment of great public works, and to the acquirement of that control by mankind of the natural conditions hostile to human progress which we may call, as did Lord Bacon, "the establishing of the kingdom of man."

The men who have expelled yellow fever from Cuba 
and Panama have not merely done a piece of sanitary cleaning up; they have first imagined and then created, by the force of human will, directed and maintained by conviction of the reality of science, a new thing - the tropics without deadly fever, the tropics as a healthy and welcome home for the white man. That is comparable to the work of a great artist in the directness of its appeal; it is in its actual detail the result of the combination of the skill of the engineer with the foresight and absolute domination of his human agents of a military genius.

For this magnificent work the highest credit is due to the United States chief sanitary officer, Colonel Gorgas. It is well known how the American Medical Commission in Cuba proved six years ago that yellow fever is conveyed from man to man solely and entirely by a gnat common in Central America, known as Stegomyia, and further, how by carrying out measures for preventing the entrance of these gnats into dwelling-houses, and especially by keeping them away from yellow fever patients so that they fail to obtain and carry the yellow fever germ, even if they do bite healthy men, Colonel Gorgas and his associates practically eradicated yellow fever in Cuba The bite of the Stegomyia gnat is the only way in which a man can acquire yellow fever, and the gnat which bites him must have taken up the germs of yellow fever from another man-twelve days (no less) previously.

The application of this knowledge and the methods devised to give it effect is what has now rendered the construction of the Panama Canal by the United States Government possible. The French Canal Company employed an army of labourers, numbering from I 5,000 to I 8,000 men. They lost, almost entirely by death from yellow fever and malaria, so many of their workmen that others refused to undertake the deadly job, and there was a general panic. The death-rate was in I 884 over 60 per 
I000. In I 885 it was over 70 per 1000. The work was abandoned. In May 1904 Colonel Gorgas and his forces took possession of the canal zone. This is a zone of territory running fifty miles north and south, with a goodsized town - Colon - at one end of it and another Panama - at the other end of it. Many hundreds of men were at once organised and set to work to destroy in both the towns the Stegomyia gnat. This was effected by doing away with all the breeding-places of the gnat, that is, screening and covering every water receptacle in the town, so that the gnats or mosquitoes cannot breed. Then a fumigating process was carried out in all houses and buildings, great and small, to destroy such gnats as were still alive. No less than $200,000 \mathrm{lb}$. of pyrethrum and $400,000 \mathrm{lb}$. of sulphur were used in this fumigation. In December 1905 the last case of yellow fever occurred. It took sixteen months of the work just described to effect this.

In a different way the Anopheles gnat or mosquito, which carries the germ of malaria from man to man, was got rid of. This gnat breeds in clean water, where grass and weeds grow; it belongs chiefly to country districts. As it rarely flies more than 200 yards it was sufficient to destroy the breeding pools within that distance of the workmen's houses, camps, and villages. All the windows and doors of all houses were fitted with wire-gauze screens, which prevent the entrance of the gnats, and the population was furnished with quinin, a dose of 3 grs. a day being ordered to bring the men into such condition that the malaria parasite would not thrive in the blood even if introduced.

The object with which Colonel Gorgas and his associates started was accomplished in less than two years. The control of yellow fever and malaria has become even more complete in the two years which have followed. It 
is two years since yellow fever disappeared from the entire zone, including the two towns. Malaria has not been so completely destroyed. The employés of the Canal Commission and Panama Railway now number 45,000. The death-rate of this entire force, including both black $(33,000)$ and white $(12,000)$ employés, was, in the month of December 1907 only I 8 per 1000 per annum-less than that of the city of Liverpool, which was 20 , or that of Salford, which was over 19. Of all the white employés the death-rate was only 13 per 1000 per annum. In the year 1906 (whole year), among the 6000 white employés who had come from the United States, including some 1200 women and children, their families, the death-rate from disease was only 4 per rooo. Pneumonia has been a chief cause of death among the negro labourers, but seldom affects the whites. Malaria caused, in the whole army of labourers, only six deaths in December 1907, as against thirteen in the smaller army at work in the same month in 1906. There were 800 cases of malaria in the whole army of 45,000 employés in December 1907.

It is thus apparent that Colonel Gorgas has converted this deadly zone from which negroes and white men hurried in a panic of fear twenty years ago into a region as healthy-that is to say, with as low a death-rate-as an ordinary North American or English city. No doubt allowance must be made in the comparison for the special nature of the population brought together on the canal zone. This is favourable to a low death-rate, in so far as it consists of strong adults, excluding old people and very young children, but unfavourable in so far as it consists of negroes and mean whites, who are even less amenable to sanitary regulations and precautions than the population of an English city. Colonel Gorgas writes that now that it is shown that any population coming into the tropics can protect itself against yellow fever and malaria by 
measures which are both simple and inexpensive, the Anglo-Saxon will find life in the tropics more healthful than in the temperate zones, and tropical countries which offer a much greater return for man's labour than do those of the chilly temperate zone, will be in the course of the next two or three centuries occupied and populated by the white races. Such an unpleasantly cold spring as that which all Europe endured last year makes one wish that the tropics generally were already arranged by Colonel Gorgas for our reception, and provided with a sanitated white-faced population. We could go and live there, warm and comfortable, all the year round, enjoying the rich luxuriance of tropical nature without fear of either chill or fever. 


\section{II}

\section{UNIVERSITY TRAINING}

A $\mathrm{T}$ Manchester last year, when they installed Lord A Morley, the Secretary of State for India, as Chancellor of the University, the Right Hon. Arthur Balfour delivered a very interesting address, in which he declared himself a believer in the gospel of "Science the Master." Mr. Balfour's speech did not imply any disregard for the pursuit of historical knowledge and a training in literature and the use of language, but it was a clear recognition of the fact that when the great purpose for which universities exist is considered it must be asserted in no hesitating terms that the discovery of new knowledge is the most important activity which a university can foster. To train men (and women, too) to use their faculties not merely to acquire knowledge of what has been discovered by others in the past, but to discover new things and to gain further control over the conditions in which we live, and to secure further understanding not only of nature but of man-that is the great business of the university.

It was fortunate that Mr. Balfour was present and able to strike this note, for Lord Morley, the new Chancellor, had not expressed any such conception of the aims of a university. He declared that, so long as the Greeks have anything to teach us we should not 
cease to study the Greeks. But, whilst we may agree to this, it is well to remember that, though pleasure can still be obtained from Greek poetry and prose by those who have thoroughly mastered the Greek language, yet almost all, if not quite all, that the Greeks have to teach us has been by this time translated and dealt with by our own writers. Consequently, although we may cordially approve of the study of ancient civilisations and ancient literatures and languages, both Greek and barbarian, as part of the enterprise of a university, it is somewhat excessive, not to say belated, to set up the study of Greek or of any other historic language and civilisation as the chief and distinctive boon which universities can offer to their scholars. The matter has, indeed, been thrashed out, and Greek, together with what is called the "study of literature" (but is usually an ineffective dabbling in it), has been put into its proper subordinate place in all the universities of Europe and in most of those of Great Britain. The illusion that flowers of speech and mastery of phrase (though all very well if honestly used) are an indication of any knowledge or capacity which can be of service to the community, has been, in late years, to a very large extent, dispelled.

The concluding words of Mr. Balfour's speech were: "The great advancement of mankind is to be looked for in our ever-increasing knowledge of the secrets of nature -secrets, however, which are not to be unlocked by the men who pursue them for purely material ends, but secrets which are open in their fulness only to men who pursue them in a disinterested spirit. The motive power which is really going to change the external surface of civilisation, which is going to add to the well-being of mankind, which is going to stimulate the imagination of all those who are interested in the universe in which 
our lot is cast-that lies after all with science. I would rather be known as having added to the sum of our knowledge of the truth of nature than anything else I can imagine. Unfortunately for me, my opportunities have lain in different directions."

That is a splendid confession of faith. I do not remember that any German statesman of like authority and standing has ever given expression to so full and ample a belief in the value of science. Yet German statesmen have acted, though they have not spoken. They have arranged for, and continually are arranging for, a far larger expenditure of public money upon scientific training and investigation than is assigned to such purposes in this country. Every department of government in Germany has its thoroughly trained, welltaught, well-paid body of scientific experts and investigators, and, moreover, the whole official world, from the Emperor downwards, has a real understanding of what science is, of the folly of attempting to proceed without it, or allowing persons who are ignorant of it to act as administrators. The need for science is not merely recognised in words, but steps are taken, and have been taken now for many years, actually to secure in German public offices and public administration the predominance of that scientific knowledge which the German statesmen, as well as Mr. Balfour, consider so necessary. Is it too much to hope that in this country those who recognise the value and importance of scientific knowledge will also take steps to re-arrange our Government departments so as to give them the advantage of guidance by men trained in the knowledge of nature, rather than by men ignorant of the very existence of such knowledge?

The universities hold the central position in this matter, and it is their influence and wealth which the State should 
insist on directing towards the extension and diffusion of science. Those who address the public on this subject not infrequently take what seems to me to be a disastrous line at the start. They speak of the new universities as the universities of the people, and hand over Oxford and Cambridge, with their enormous endowments, their history and tradition, to the wealthy class. Such usurpation cannot be tolerated. It is monstrous that the endowments of the colleges of Oxford and Cambridge, which were thoroughly popular and democratic in their foundation, should be, even for a moment, regarded as the peculiar property of the wealthy. It is also monstrous to suppose that it is anything less than disastrous to consign the well-to-do classes in any community to an empty sham of ancient "culture" rather than to imbue them with the real and inspiring culture of the modern renaissance. It is because this notion is allowed to gain ground that the enormous funds of the colleges and universities of Oxford and Cambridge, amounting to more than three-quarters of a million pounds annually, are to a large extent, though not exclusively, employed in keeping up a couple of huge boarding-schools, which are shut for six months in the year.

It is owing to this that it is the rarest thing to find in Oxford or in Cambridge a great teacher who lectures or demonstrates to an eager following of disciples. An overwhelming majority of the young men who go as students to these universities have no intention of studying anything. They are sent there in order to be submitted to college discipline and to have, subject to that safeguard, a good time. A large number are handsomely paid by scholarships in order to induce them to go thereand would not go there at all unless they were so paid. They do not find such teachers there and such an effective occupation of their student years as would induce them, 
if unpaid, to seek the university, or to pay fees out of their own pockets for the opportunities of seriously pursuing any branch of learning or science within its walls.

The inefficiency of the old universities is to a large extent the cause of the neglect and ignorance of science in the well-to-do class, who furnish the men who become Government officials of all kinds and members of professions which influence public opinion. But this inefficiency of the old universities is not due to their devotion to literary studies and to abstract science, nor to their objection to the pursuit of practical and commercial studies. That excuse is sometimes put forward for them, though at this moment they are, in fact, setting up laboratories and lecture-rooms for engineering, agriculture, forestry, mining, and such applications of science. Nor is it money which is really wanting at either Oxford or Cambridge, although they are both begging for it from the public. What Oxford and Cambridge want is not money but men; men as teachers-"professors" is the usual title given to them in a university - who must be the ablest, each in his own line, in the whole world. If such professors existed in either Oxford or Cambridge, and were allowed to teach, the town (if not the colleges!) would be full to overflowing of students-eager to pay their fees and to spend, not three short terms of seven weeks in each year, but the whole year, and many years, in the laboratories and lecture-rooms of those commanding men.

To obtain such men-to set the machinery at workyou must pay them handsomely, and give them authority and the means of work. Once they were at work, the mere fees of the students would furnish a splendid revenue. There is plenty of money at Oxford and at Cambridgea superabundance, in fact-which could and should be applied to this purpose, namely, that of securing and 
establishing there the greatest teachers in the world. The money is at present administered by the colleges according to the directions given in recent Acts of Parliament, and by no means in any blind obedience to the original intentions of the founders of the colleges. It is to a large extent wasted. That portion of it paid out as "scholarships" is for the most part wasted in bringing students to a place where they cannot get the best opportunities of study, and the rest is unwisely applied (not so much by the tenants for life or administrators of college funds as by rigid Act of Parliament) to providing an excessive number of totally inadequate salaries by which a corresponding number of young men are induced to enter upon the career of teachers as underpaid college Fellows. 


\section{III}

\section{DARWIN'S THEORY}

N Wednesday, the Ist of July 1908, half a century had passed since Darwin's Theory of the Origin of Species was made known to the world. Fifty years have now been completed since that immortal book, The Origin of Species, was published, and a hundred years since Charles Darwin was born.

It is not every one who is in a position to understand how great and momentous was the occasion when Sir Charles Lyell and Dr. Joseph Hooker communicated to the Linnean Society of London, on the Ist of July 1858, two papers, one by Charles Darwin, the other by Alfred Russel Wallace, under the common title, "On the Tendency of Species to form Varieties: and on the Perpetuation of Varieties and Species by Natural means of Selection." The reason for this conjoint communication to the Linnean Society was that Darwin, who had been working for years at the subject, and had already, in 1842 , drawn up a statement of his theory, not for publication, but for the consideration and criticism of his friend Hooker-unexpectedly received from Alfred Russel Wallace, who was, and had been for some years, away in the Malay Archipelago-a manuscript of an essay on the origin of species, containing views identical with his own, and even phrases similar to those he had himself found it necessary 
to invent. Thus Wallace speaks of the "struggle for existence," whilst Darwin had used the term "struggle for life." Darwin had been urged by his friends before this to publish an abstract or statement of his conclusions, but now that he had received Wallace's manuscript, he declared in a letter to Hooker, "I would far rather burn my whole book than that he or any other man should think that I had behaved in a paltry spirit." And so Lyell and Hooker took the matter in hand, and communicated to the Linnean Society, accompanied by an explanatory statement, the two independent papers, setting forth, as they say, "the results of the investigations of the indefatigable naturalists, Mr. Charles Darwin and $\mathrm{Mr}$. Alfred Wallace." Such loyalty and regard to each other as Darwin and Wallace showed then and ever after form a delightful feature in the history of this great discovery. A wonderful thing is that Hooker, now Sir Joseph Hooker, the greatest botanist of the past century, the constant friend and comrade of Darwin, is still alive, and that Alfred Russel Wallace, too, is still with us. They both were present when the Linnean Society celebrated the meeting of fifty years ago.

The views of Darwin and Wallace have now become the established doctrine of science. They have led to the universal recognition of "the origin of species by descent with modification." That is a statement, in other words, to the effect that all the various kinds of living things have been gradually produced by natural birth from predecessors which differ from them only slightly in the later stages of time, but become simpler and less like their descendants as we go further back, until we reach the simplest living things. It has led to the conviction that there has been no exceptional or " miraculous" suspension of the order of Nature in this process, but that all has come about in due and regular course, in virtue of the 
properties of natural things, which we know as the laws of physics and chemistry. Most important and dominating of all these results is the inevitable one that man himself has come from animal ancestors, in the same way, and(this is the greatest and most far-reaching conclusion of all) - that he is still subject to those natural processes of change and development by which he has reached his present phase; that he must completely understand them and control them (so far as such control is possible) in order to maintain a healthy, happy, and improving race of men on the face of the globe. This great possession-the earth and all that lives on it-is, as Lord Bacon phrased it three hundred years ago-the Kingdom of Man. Man has but to use his intelligence in order to take control of it. The knowledge of his own relation to it, and of the ways in which the human race is affected for good and for ill, through the operation of the self-same processes which affect the breeding, the improvement, the health, the disease, the destruction, and the perfecting of other living things, has once and for all been placed within man's reach by the discoveries of Darwin and Wallace.

Before Darwin-that is, before Ist July I 858 -the origin of the different species of animals and plants was called by great thinkers like Sir John Herschel, the astronomer, "the mystery of mysteries." The word "species" was defined as "an animal or plant which in a state of nature is distinguished by certain peculiarities of form, size, colour, or other circumstance from any other animal or plant, and propagates after its kind individuals perfectly resembling the parent, its peculiarities being therefore permanent." So wrote a great naturalist in the days before Darwin. This definition may be illustrated by two common English birds-the rook and the crow. They differ from each other in slight peculiarities of form, structure, and habits, and, moreover, rooks always 
produce rooks, and crows always produce crows, and they do not interbreed. Therefore it was held that all the rooks in the world had descended from a single pair of rooks, and all the crows in like manner from a single pair of crows, while it was considered impossible that crows could have descended from rooks, or rooks from crows. The "origin" of the first pair of each kind was a mystery, and by many persons was held to have been due to a miraculous and sudden act of "creation." But besides our crow and rook, there are about thirty other birds in various parts of the world so much like our crow and rook that they are commonly called crows, and are all regarded as "species" of the genus crow (or Corvus). It was held before Darwin that all the individuals of each of these "species" were descended from an ancestral pair of crows of that species. There would have been thirty different original kinds, the "origin" of which was unknown, and by naturalists was regarded as a mystery. Now, on the contrary, it is held that all the thirty living species are descended from one, not from thirty, ancestral species, and have been gradually modified to their present character in different parts of the world; and, further, that this ancestral species was itself derived by slow process of change and natural birth from preceding crowlike birds no longer existing.

As Mr. Alfred Russel Wallace has said in his most readable and delightful book, Darwinism-where he gives all the credit and glory to his great fellow-worker: "Darwin wrote for a generation which had not accepted evolution-a generation which poured contempt on those who upheld the derivation of species from species by any natural law of descent. He did his work so well that 'descent with modification' is now universally accepted as the order of nature in the organic world, and the rising generation of naturalists can hardly realise the novelty of 
this idea, or that their fathers considered it a scientific heresy to be condemned rather than seriously discussed."

For those who are not naturalists or men of science it is an object-lesson of the highest importance, that the speculations and observations which have led to the general acceptance of a new view as to the origin of the species of birds, butterflies, and flowers-in itself apparently a matter of no consequence to human life and progress - should have necessarily led to a new epoch in philosophy, and in the higher state-craft; in fact, to the establishment of the scientific knowledge of life as the one sure guide and determining factor of civilisation. How to breed a healthy, capable race of men, how to preserve such a race, how to educate and to train it, so that its best qualities of mind and body may be brought to activity and perfection-this is what Darwinism can teach us, and will teach us when the great subjects of inheritance and of variation are more fully investigated by the aid of public funds, and when the human mind has been as carefully examined and its laws as well ascertained, as are those of the human body. There is no reason for delay; no excuse for it. For two thousand years the learned men of Europe debated as to whether this or that place was the site of ancient Troy, or whether there ever was such a place at all. At last (only twentyfive years ago) a retired man of business, named Schliemann, had a "happy thought" - it was not the thought of a learned pedant, but of a scientific investigator. He said, "Let us go and see." And at the expense of a few thousand pounds he went and found Troy and Mycenæ, and revealed-"dis-covered"-the whole matter. That was the most tremendous and picturesque triumph of the scientific method over mere talk and pretended historical learning which has ever been seen since human record has existed. It ought to be told to every boy and girl, 
for it is the greatest and most obvious proof of the overwhelming power of the investigation of tangible things and the futility of chatter, which has ever been seen. It is enough to inspire hope and belief in experiment even in the breast of a Member of Parliament, or of a Minister of the Crown. 


\section{IV}

\section{DARWIN'S DISCOVERIES}

A LARGE proportion of the public are not aware of A the amount of experiment and observation carried out by the great naturalist whose memory was honoured by a splendid ceremony at the University of Cambridge in the summer of 1909. There are, I am sure, not a few who are under the impression that Darwin, sitting in his study or walking round his garden, had "a happy thought," namely, that man is only a modified and improved monkey, and proceeded to write an argumentative essay, setting forth the conclusion that mankind are the descendants of some remote ancestral apes. Of course there is an increasing number of more careful and inquiring men and women who take advantage of the small price at which Mr. Darwin's wonderful book, The Origin of Species, is now to be bought, and have read that and some of his other writings, and accordingly know how far he was from being the hasty and fanciful theorist they previously imagined him to be. It is the great distinction of Darwin that he spent more than twenty years of his life in accumulating the records of an enormous series of facts and observations tending to show that the species or "kinds" of animals and plants in nature can and do change slowly, and that there is, owing to the fact that every pair produces a great number of offspring (sometimes many thousand), of which only 
a single pair, on the average, survive, a necessary selection of those which are to survive and breed, accompanied by a rejection and destruction of the rest. This "natural selection" or survival of favoured varieties, he was able to show, must operate like the selection made by breeders, fanciers, and horticulturists, and has in all probability (for in a history extending over hundreds of thousands of years we must necessarily deal with "probabilities," and not with direct demonstration) produced new forms, new kinds, better adapted to their surroundings than the parental forms from which they are derived.

It was necessary, in order that Darwin should persuade other naturalists that his views were correct, that he should show by putting examples "on the table" that variations occur naturally and in great diversity; further, that there is great pressure in the conditions of life, and a consequent survival of the best-suited varieties ; further, that there is in reproduction a transmission of the peculiar favouring character or quality which enables a variety to survive, and thus a tendency to perpetuate the new quality. It was not enough for Darwin to "imagine" that these things might be so, or to make the notion that they are so plausible by arguments drawn from existing knowledge. He had to do that: but also he had to make new inquiries and discover new things about animals and plants which fitted in with his theory and would not fit in either with the notion that all plants and animals were created-as the poet Milton supposed - out of lumps of earth and muddy water, suddenly, in the likeness of their present-day descendants, nor with some other notions, such as that of the able and gifted French naturalist Lamarck. And he spent the later twenty years of his life in doing so, just as he had spent the previous twenty years in collecting a first series 
of facts and observations justifying his theory before he announced it to the world.

A great difference between Lamarck and Darwin exists, not only in their two theories as to the mode of origin of the vast diversified series of kinds or species of plants and animals, but in their way of stating and dealing with the theory which each thought out and gave to the world. Lamarck had a great knowledge of the species of plants and animals, partly through having collected specimens himself when he was an officer in the French Republican army which was employed on the Mediterranean shores of France and Italy more than a hundred years ago, and partly through his later official position in the great natural history museum at Paris, where large collections passed through his hands. He was a man of very keen insight and excellent method, and did more to plan out a natural and satisfactory "classification" of animals than any one between his own day and that of Linnæus. His theory of the origin of species was essentially an opposition to the then popular view that the species of living things have been made by the Creator so as to fit the conditions in which they live. Lamarck contradicted this view, and said in so many words that the real fact is that the peculiar specific characters of animals or of plants have not been created for their conditions, but, on the contrary, that the conditions in which they live have created the peculiarities of living things. In so far his conception was the same as Darwin's. But Lamarck then said to himself: How do the conditions create the peculiarities of different living things? And he answered this question by an ingenious guess, which he published to the world in a book called Philosophical Zoology, without taking any steps to test the truth of his guess.

That is where Lamarck's method and attitude as a 
scientific man is so greatly inferior to that of Darwin. Lamarck, sitting in his study, said animals (and plants too) must be affected by the conditions around them, so that an individual as it lives and grows becomes to a certain degree slightly changed by and adapted to those conditions. This, he said, we all see in human beings and familiar animals and plants. Now, he said, we have only to admit that the changes so acquired are (especially when both parents have been similarly changed) transmitted to the young in the process of generation, and to some degree "intensified," in order to recognise that of necessity there is in nature a constant change and progression of living forms, consisting in a more and more elaborate "adaptation" to the conditions of life, which will be varied and lead to new adaptations as the living things spread over the earth or as geological changes occur. He cited the long neck of the giraffe as an example of what he meant. In regions where there was frequent and extensive drought, a deer-like creature would eat the lower leaves of trees when the grass was dried up and dead. It would strain and stretch its neck in reaching after the higher leaves, and the individuals thus straining and stretching would become an inch or two longer in the neck in consequence. These individuals would, said Lamarck, transmit their increased length of neck to their offspring, who again would strain and stretch after higher leaves, and get a further increase of neck-length, and so it would go on, little by little, over many thousand generations, until the neck-stretchers had become well marked and distinguished by their long necks from such of their ancestral stock as survived in other regions where, the grass being good, there was no inducement to straining and stretching the neck.

Now the great difference between Lamarck and Darwin is that Lamarck was quite content to state 
the ingenious supposition illustrated by the imaginary history of the giraffe, and to declare that this was the law of Nature and is actually going on every day, without, so to speak, getting out of his chair. He never attempted to show by observation or experiment that such a change of form as the stretching of the neck by straining after food could and did occur, or that if it did that it could be transmitted by a parent or couple of parents to their offspring. And consequently for many years no one attached much value to Lamarck's notions on the subject. When, fifty years later, Darwin's very different theory became widely received, based on the demonstrable fact that congenital variations (not stretchings and warpings acquired in the lifetime of a parent, but variations which are inborn, and occur in some but not other individuals living under one and the same set of conditions) are transmitted to offspring, and that those among these variations which are favourable to success in life will enable their possessor to survive and to produce young inheriting those favourable variations-then it occurred to those naturalists who were inclined to believe in Lamarck's suggestion to inquire into the solid facts in regard to that also, and to see whether his bare statement was true. From that day to this, it has never been shown that it is true. It is, indeed, to begin with, a rare thing to find instances of either wild animals or wild plants which, growing up in unusual conditions, have their structure altered and "adapted" so as to be more serviceable in those unusual conditions than their usual structure would be; and in those cases where such adaptive alterations have been produced, every experimenter is agreed in stating that he has found that when (even after several generations in the changed conditions) the young are restored to their original conditions, they simply grow up into the original forms: no permanent change in the stock or race has 
been effected. Every attempt to show by experiment that a new character can be acquired by the stock in this way, and show itself by heredity alone-when the modifying adapting conditions are removed-has completely failed.

On the other hand, Darwin himself and his followers have made almost endless experiments and observations on plants and animals, establishing facts as to structure and the relation of special kinds of living things to their surroundings which can only be explained on the supposition that Darwin's theory is true in detail ; that is to say, not merely that the kinds of animals and plants have arisen from previous kinds by natural descent-that supposition is much older than either Darwin or Lamarck -but that the method by which the transformation has been brought about is $(a)$ the occurrence in every generation of every animal and plant of minute variations in every, or nearly every, part, and (b) the continual selection in the severe struggle for existence of those individuals to grow to maturity and reproduce, which happen to present favourable variations, which variations are accordingly transmitted to the next generation, and may be intensified, so far as intensification is of value, in each succeeding generation.

A book full of observations and reflections about the structure, habits, and mode of occurrence and geography of a great number of plants and animals is Darwin's Journal of Researches, published in 1845, and now republished as $A$ Naturalist's Voyage. In order to know very minutely the differences and resemblances between all the kinds or species of one group of living things Darwin studied for eight years the "cirrhipedes," the name given to the sea-acorns and ships' barnacles which occur in all parts of the world, some living on rocks, some on the backs of turtles, others on whales, on the feet of birds, 
on bits of floating wood or of pumice-stone, and some on one another! They are all hermaphrodites, but Darwin found in several a most singular thing, namely, the existence of minute males, complemental to and parasitic on the hermaphrodites. His discovery was doubted and denied, but he had the pleasure of seeing it at last fully confirmed thirty years after his book on cirrhipedes was published.

Darwin discovered that the presence of the same species of plants and of some few animals on distant mountain summits and in the Arctic region is due to the former extension of ice between these situations during the last glacial period. He was, before everything else and by necessity for the examination of his theory, a geologist, and wrote many valuable geological memoirs. The history of the origin of the species of living things consists largely in tracing them to extinct creatures, and in showing what were the possible migrations and what the conditions of land and water, temperature and vegetation, in past periods, and in regard to given areas of the globe. The book on the Fertilisation of Orchids was the first published by Darwin after the Origin of Species. In it he showed how the marvellous shapes and colours and mechanisms of the flowers of orchids are adapted to ensure cross-fertilisation by insects, and how they can be explained as originating by the natural selection of variations-if the value of crossfertilisation is once recognised. The explanation of the reason for the existence of two kinds of primrose flowers -the short-styled and the long-styled-clearly arrived at by him as being a mechanism to secure crossfertilisation, delighted him in 1862, and led him to discover the same sort of modification in other flowers. Then, in 1864, he published his researches on Climbing Plants, and later a book on the Movements of Plants, in 
which he discovered the mechanism and the wonderful variety of movements of plants, and showed their value to the plant, and consequent origin, by natural selection.

$\mathrm{He}$ especially loved to discover evidence that plants can do many things which had been thought to be only within the powers of the other section of living thingsthe animals; and finding during one summer holiday that the beautiful little sun-dew moves its red-knobbed tentacles so as to entrap minute insects, he discovered the whole history of Insectivorous Plants, and showed that there are many plants of various groups which catch insects and digest them in a sort of stomach, as an animal might do. Thus the water-holding pitchers of the pitcherplants of tropical forests were explained as being foodcatchers and digesters of great value to the nutrition of the plant, and their gradual formation by variation and natural selection rendered comprehensible.

His greatest book next to the Origin-containing an immense quantity of original notes and observations and valuable information from all kinds of breeders and fanciers -is the Variation of Animals and Plants under Domestication (1868). The facts recorded are discussed in the light of the great theory, and honest, fair-minded consideration is given to those which present difficulties as well as to those which clearly favour it. In 187 I came the Descent of Man, followed in 1872 by the Expression of the Emotions in Men and Animals-in which, again, it was shown that the facts as to the likeness between man and apes can be explained on the theory that natural selection and survival of favourable variations have been at work, and that the facts are hopelessly without meaning or explanation on any other hypothesis. His last published book was on The Formation of Vegetable Mould through the Action of Worms, in which he not only showed what an important part earthworms play in burying stones and 
rocks, and in fitting the ground for the growth of plants, but recorded some discoveries as to the senses of worms and as to their treatment of leaves by a digestive fluid exuded from the mouth so as to soften a leaf before swallowing it.

Every one of Darwin's books abounds with new facts and new points of view disclosed by the application to first one thing and then another of his vivifying discoverycausing theory of natural selection. The subsidiary theory of the selection of brilliantly coloured males by females in pairing, as a cause of the brilliant colours and patterns of many birds and insects, is developed in his Descent of Man. It led him to many important discoveries and observations as to the colouring and ornamentation of animals, and when considered, together with Wallace's and Bates's theory of mimicry and of the warning and protective colourings of insects, goes far to explain all the specific colouring of animals and plants as due to natural selection and survival. A theory which has produced such prodigious results in the way of "explaining" all forms, colours, habits, and occurrences of living things -as has that of Charles Darwin-simply holds the field against all comers. When Lamarck's theory has been shown to be consistent with the most elementary facts as to heredity, and further to afford a rational explanation of any group of biological facts, it will be time to consider how far it may be entertained in conjunction with Darwin's theory-but not until then. 


\section{V \\ DARWIN'S THEORY UNSHAKEN}

T $T$ seems ill-mannered, if not ill-natured, that the year of the centenary of Charles Darwin's birth should have been chosen by owners of anonymous pens in order to alarm the public mind with the preposterous statement that his celebrated and universally accepted theory of the origin of the species or kinds of plants and animals by natural selection, or "the survival of favoured races in the struggle for life," is undermined and discredited. Such a statement once coolly made in the public Press is necessarily believed by a large number of uninformed readers, and, like all calumny, is none the less relished by the foolish, and, for the moment, none the less harmful, because it is baseless.

Those who seek to belittle Darwin's theory show, whenever they venture to enter into particulars, that they do not know what Darwin's theory is. They confuse it with other theories, and even imagine that some enthusiastic Darwinians who have tried to add a chapter here or there to Darwin's doctrine, are opponents of the great theory. Let me briefly state what that theory is :

It rests on three groups of facts-matters of observation, which are not theory or guess-work at all-but admitted by every one and demonstrated every day. These are-(I) Living things, each in its kind, produce 
a far larger number of young than can possibly grow up to maturity, since the kind of food and the situation necessary to each kind are limited and already occupied. Only one oyster embryo out of every five million produced (the reader may refer to p. I37 on this subject) grows up through all the successive stages of youth to the adult state. The total number of a species of animal or plant on the whole area where it is found does not increase. Even in those which produce a small number of young, there is great destruction, and taking all the individuals into consideration, only a single pair of young arrive at maturity to replace their parents. There is no exception to the rule that every organic being naturally multiplies at so high a rate that, if not destroyed, the progeny of a single pair would soon cover the earth. The elephant is reckoned the slowest breeder of known animals; it commences to breed at 30 years of age, dies at 100 , and has six young in the interval. After 750 years, supposing all the offspring of a single pair fulfilled the rule and were not destroyed in an untimely way, there would be nearly nineteen million elephants alive descended from the first pair. There is then no doubt as to the enormous excess in the production of young living things, nor as to their necessary competition with one another of the most severe and inexorable kind; nor again as to the necessary death, in many species, of hundreds and thousands, for every one which survives to maturity and in its turn breeds.

(2) The second great fact is that among all the young born to a pair of parents, no two are exactly alike, nor are any exactly like their parents; nor are any two taken from all produced by all parents of that species exactly alike. They all resemble their parents at the corresponding age, in a general way and even very closely; but the resemblance is far from amounting to identity. 
This is called "variation." It is familiar to us all in the case of the organism which we know best, and observe most closely, namely, man. It is also a matter of common observation in the case of dogs, cats, horses, and other domesticated animals. Many of these "variations" are exhibited in points of size, proportion, and colour, which are easily noted at once by the eye. But "variation" is really a deep-seated thing, and depends on causes which lie below the surface. We know that the offspring of men and of animals and of plants, give evidence of variations in what we call constitution, tendency, temperament, aptitude, strength, and that the colour, and even size of this or that part, are really only indications of a deep-seated difference in the living chemistry, the forces of nutrition and growth which reside in the living substance. The fact that many thousands of a species may be born and only a few survive, means therefore that many thousand varieties, often varieties not readily measured by the eye, are produced in each generation, from which a few individuals are in some way "selected" for survival.

(3) The third great fact is that though there is variation, amongst all the offspring in each generation, there is also a continual and definite inheritance by offspring of the qualities and structure of their parents to a degree which altogether preponderates over the variations. To put it in another way, we all know that every parental organism transmits to its young not only the qualities and structure of the species, or of the race, or of the family, but also transmits its own peculiarities or variations in which it departed from its parents, and from its brothers and sisters. This is best illustrated by our daily experience of human families.

These facts being admitted, and abundantly illustrated and traced in detail by years of observation and experi- 
mental breeding in all kinds of living things by hundreds of careful observers who have published the records of their studies, we come to the step where Darwin makes use of supposition or hypothesis. The question is, "Does the one which, out of the thousands of slightly different varieties, survives-do so by haphazard ? or is there a necessarily acting state of things which selects that one special variety for survival ?" Gardeners and breeders of pigeons, dogs, and cattle deliberately select the variations which they desire, breed from them, and so carry on by inheritance the special variation-whilst they ruthlessly destroy or restrain from breeding the numerous other variations in their "stock" which they do not desire. "If," said Darwin, "there is any necessarily selective mechanism in Nature which could act as the breeder does, new varieties might be 'naturally' selected, and changes of form and appearance naturally established, which in the course of long ages would amount to such marked differences as separate what we call one species from another." $\mathrm{He}$ showed that there is a natural mechanism of the required kind. "Since," he says, "the competition among the members of any one kind or species for a place in life is so very severe, and the hostile circumstances so varied, and since all the competing offspring differ by 'variation' ever so little from one another, those varieties which are better suited in even the smallest degree to hold their own not merely in fighting with the others, but in withstanding injurious influences, in escaping enemies, and in procuring food, will be the ones which will survive, when a large number of cases, many thousands, extending over a large area and many years, are considered. Those which are 'best fitted' to get through the exceedingly numerous dangers and difficulties of life will be the survivors." Hence we get the survival of the fit-the fit variationsby natural selection in the struggle for life. This, it 
will be observed, is an inference, and not a direct observation.

So long as the conditions remain practically or effectively unchanged, the animal or plant already "fitted" to them will be succeeded by those of its offspring which most resemble it in the essential points of "fitness." But we know that in the course of ages, more or less rapidly, climates change, land emerges from the sea, islands join continents, continents become scattered islands, animals and plants migrate into regions previously uninhabited by them. As such changes gradually come on, the natural selection of favoured varieties will necessarily lead to the survival of others than those previously favoured, other variations better suited to the new conditions will survive.

The natural selection of favoured variations would not amount to much, were the variations not perpetuated by transmission to the young which they produce. This, it is common knowledge [see (3)], does take place. It is known also that a variation so established is as a result of the regular process of variation presented in larger volume or emphasised in character in some individuals of subsequent generations, and by continued "natural selection" it may become more and more a prominent or dominant feature of the race.

So far, the only assumption made by Mr. Darwin is that any or some of the endless variations which occur in all the offspring of wild plants and animals, in various combinations and degree in each individual, can be sufficiently important to determine the survival or nonsurvival of the organisms possessing them. That is a matter which has been largely studied and discussed. The verdict of those who have studied on the spot (as Darwin himself did) the teeming life of the tropics, the insects, birds, and plants of those regions, is that we are justified in considering that small variations are sufficiently 
important to turn the scale in favour of survival or nonsurvival. It is not easy for a man who is not a determined naturalist, constantly observing the ways of wild living things, to appreciate the evidence as to the efficacy of small variations, even were I able here to submit it to him. It is to be found in the published works of an army of investigators. In any case it is granted that effective variations-whether small or great-occur in nature, and that natural selection favours and perpetuates the new and fitter variety to the exclusion of the less fit.

The real difficulty to most people comes in the supposition next made by Mr. Darwin-namely, that this slow process of change by natural selection of favoured variations and their transmission and perpetuation by inheritance is sufficient to effect by its continued operation through enormous ages of time the conversion of a race of ancestral three-toed zebras into the one-toed horse of to-day; before that, of five-toed beasts into three-toed; at an earlier stage of fishlike creatures into four-footed land animals, and so on. You have to picture the whole series of animals and of plants which are now or ever have been, as two gigantic family trees or pedigrees, meeting in common ancestors of the simplest grade of microscopic life. All the diverging branches and twigs of these great "family trees" have been determined by the adaptation of living form to the endlessly varied conditions of life on this planet, by the natural selection or survival of variations and the transmission and accumulation of those variations from parent to offspring. This is a tremendous demand on the imagination. It is, however, not a difficult one to concede, when one is acquainted with the facts and conclusions of geology. The history of the crust of the earth was explained twenty years before the date of Darwin's theory by Charles Lyell as due to the continued action through immense periods of time of the 
same natural forces which are now at work. And, moreover, the examination of the successive stratified deposits of the earth's crust has yielded the remains of whole series of animals and of plants (simpler in character the older and deeper the rock in which they occur), which can be satisfactorily explained and interpreted as the ancestral forms from which present organisms have been developed.

The theory of the natural selection of variations as the moving spring in the gradual development of living forms from simplest living matter is Darwin's theory. It is not possible to find any naturalist of consideration who does not accept it. There are various views held and discussed as to the cause of variation, as to the importance of small and of big variations, as to the non-transmissibility of some kinds of variation, and as to various peculiarities in regard to inheritance. They do not for the most part touch the main features of Mr. Darwin's theory. No doubt we are learning and shall learn more about the facts of variation and the details of the process of hereditary transmission, but such increase of knowledge has not tended to undermine Mr. Darwin's theory, and does not seem at all likely to do so.

On the occasion of the celebration at Cambridge in I909 of the centenary of Darwin's birth, I was invited by the Vice-Chancellor, on behalf of the University, to deliver in the Senate-house an address, others being given by representatives of the United States (Prof. Osborne), of Germany (Prof. Hertwig), and of Russia (Prof. Metchnikoff). The following is the text of that address:-

"I feel it a great honour to be called upon to speak here to-day, and to stand, on behalf of the naturalists of the British Empire, by the side of the distinguished men whose orations you have just heard.

"I think that the one thing about Charles Darwin 
which the large majority of British naturalists would wish to be to-day proclaimed, in the first place-with no doubtful or qualifying phrase-is that, in their judgment, after these fifty years of examination and testing, his 'theory of the origin of species by means of natural selection or the preservation of favoured races in the struggle for life' remains whole and sound and convincing, in spite of every attempt to upset it.

"I am not stating more than the simple truth when I say that, in the judgment of those who are best acquainted with living things in their actual living surroundings, 'natural selection' retains the position which Mr. Darwin claimed for it of being the main means of the modification of organic forms.

"Our admiration for the vast series of beautiful observations and interesting inquiries carried out by Darwin during his long life must not lead us to forget that they were devised by him in order to test the truth of his theory and to meet objections to it, and that they were triumphantly successful. They, together with the work of Alfred Russel Wallace and many of their followers, have more and more firmly established Darwin's theory. On the other hand, no attempt to amend that theory in any essential particular has been successful.

"The nature of organic variation and of the character of the variations upon which natural selection can and does act was not, as we are sometimes asked to believe, neglected or misapprehended by Darwin. The notion that these variations are large and sudden was considered by him, and for reasons set forth by him at considerable length rejected. That notion has in recent years been resuscitated, but its truth has not been rendered probable by evidence either of such an accurate character or of such pertinence as would justify the rejection of Darwin's 
fundamental conception of the importance of minute and ubiquitous variations.

"Further, in regard to the important facts of heredity connected with the cross-breeding of cultivated varieties, especially in regard to the blending or non-blending of their characters in their offspring and as to prepotency, it seems to me important that we should now and here call to mind the full and careful consideration given to this subject by Darwin. We cannot doubt that he would have been deeply interested in the numerical and statistical results associated with the name of Mendel. Those results tend to throw light on the mechanisms concerned in hereditary transmission, but it cannot be shown that they are opposed in any way to the truth of Darwin's great theoretical structure-his doctrine of the origin of species.

"It has often been urged against Darwin that he did not explain the origin of variation, and especially that he has not shown how variations of sufficient moment to be selected for preservation in the struggle for existence have in the first place originated. The brief reply to the first objection is that variation is a common attribute of many natural substances of which living matter is only one. In regard to the second point, I desire to remind this assembly that Darwin described with special emphasis instances of what he calls 'correlated variability.' In my opinion he has thus furnished the key to the explanation of what are called useless specific characters and of incipient organs. That key consists in the fact that a general physiological property or character of utility is often selected and perpetuated, which carries with it distinct, even remote, correlated growths and peculiarities obvious to our eyes, yet having no functional value. At a later stage in the history of such a form these correlated growths may acquire value and become the subject of selection. 
"It is thus, as it seems to me, and as, I believe, to the great body of my brother naturalists, that Darwin's theory stands after fifty years of trial and application.

"The greatness of Charles Darwin's work is, and will be for ever, one of the glories of the University of Cambridge. It is fitting on the present occasion that one who speaks on behalf of English men of science should cail to mind the nature of his connection with this great University and the peculiarly English features of his life-story and of that fine character which endears his memory to all of us as much as his genius excites our admiration and reverence. Darwin was not, like so many a distinguished son of Cambridge, a scholar or a fellow of his college, nor a professor of the University. His connection with the University and the influence which it had upon his life belong to a tradition and a system which have survived longer in our old English universities than in those of other lands. Darwin entered the University, not seeking a special course of study with the view of professional training, nor aiming at success in competitive examinations for honours and emolument. He came to Cambridge intending to become a clergyman, but blessed with sufficient means and leisure to enable him to pursue his own devices, to collect beetles, to explore the fen country, and to cultivate his love of nature. It was thus that he became acquainted with that rare spirit Henslow, the Cambridge professor of botany, and it is through Henslow and the influence of his splendid abilities and high personal character upon Darwin that Cambridge acquired the right to claim the author of the 'Origin of Species' as a product of her beneficence and activity as a seat of learning.

"As an Oxford man and a member of Exeter College I may remind this assembly that in precisely the same way Darwin's dearest friend and elder brother in science, 
Charles Lyell, had a few years earlier entered at Exeter College, and by happy chance fallen under the influence of the enthusiastic Buckland, the University reader in geology and a Canon of Christ Church. The wise freedom of study permitted and provided for in those long-passed days by Oxford and Cambridge is what has given the right to claim the discovery, if not the making, of Lyell to the one and of Darwin to the other.

"Darwin's love of living nature and of the country life are especially English characteristics; so, too, I venture to think, are the unflinching determination and simple courage-I may even say the audacity-with which he acquired, after he had left the University, the wide range of detailed knowledge in various branches of science which he found necessary in order to deal with the problem of the origin of the species of plants and animals, the investigation of which became his passion.

"The unselfish generosity and delicacy of feeling which marked Darwin's relations with a younger naturalist, Alfred Russel Wallace, are known to all. I cannot let this occasion pass without citing those words of his which tell us most clearly what manner of man he was and add to his splendid achievements as an intellectual force-a light and a beauty of which every Englishman must be proud. When in old age he surveyed his life's work he wrote:- ' I believe that I have acted rightly in steadily following and devoting my life to science.'

"To have desired to act 'rightly,' and to be able to think of success in life as measured by the fulfilment of that desire, is the indication and warrant of true greatness of character. We Englishmen have ever loved to recognise this noble kind of devotion in our national heroes." 


\section{VI}

\section{METCHNIKOFF AND TOLSTOI}

THE Darwin celebration at Cambridge, in June 1909,

1 brought a wonderful assemblage of celebrated biologists from all parts of the world to this country. There never has been seen such a company of great discoverers of all nationalities in the field of natural history and the science of living things, as were present in the University of Cambridge during that week. Even philosophers, moralists, and jurists were present to join with the one great political leader of our own country who really knows and appreciates the importance of the scientific study of Nature-the Right Hon. Arthur J. Balfour-in his fervent and heartfelt tribute to the influence of Darwin's work and theory in all departments of human knowledge, thought, and activity. One of the most remarkable men present was Elie Metchnikoff. He represented both Russia, the country of his birth and earlier scientific work, and his adopted country, France, where, as sub-director of the Institut Pasteur, his later and most important researches have been carried on. Russia was also represented by Salensky, late director of the Museum of St. Petersburg, well known to us all as a discoverer in the embryology (growth from the egg) of marine animals, and by Timiriazeff, the botanist, renowned for his work on the mode in which leaf-green 
or "chlorophyll" enables green plants to obtain their food from the gases of the atmosphere. France had other representatives in Edmond Perrier, director of the Paris Museum, and Prince Roland Bonaparte.

Metchnikoff was one of the four representatives selected by the University to deliver orations in the Senate House in honour of Darwin. He especially drew attention to the influence of Darwin's theory on the study of disease. The recognition of the derivation of man from animal ancestors, and of the complete community of the structure and the chemical activity of the organs of man with those of the organs of animals, had made (he said) the study of the diseases of animals a necessary feature in the understanding of the diseases of man. The farreaching principle of Darwin that the mechanisms and processes observed in the bodies of plants and of animals (including man) must have been selected in the struggle for existence and perpetuated, because of their utility, led Metchnikoff to inquire what is the value or use of the process called inflammation and of the "eating corpuscles," or "phagocytes" (so named by him), which wander from the blood into inflamed tissues. This question had led him to the discovery that the phagocytes engulf and destroy disease-germs, and are the great protectors of the animal and human body against bacteria and other germs which enter cut and wounded surfaces, and would start disease were there not "inflammation," which is nothing more nor less than a nerve-regulated stagnation of the circulation of the blood at the wounded spot, and the consequent arrival at this spot of thousands of "phagocytes," which pass out of the stagnant blood through the walls of the fine blood-vessels. These armies of phagocytes proceed to eat up and destroy all the germs which fall on to the wound-from the air, from dirty surfaces, and from the skin. The utility of inflammation and 
its gradual development, according to Darwinian principles, in the animal series, was shown twenty years ago by Metchnikoff. His important work on "immunity" and on infection and on protection against germ-caused disease is thus seen to be one of the many flourishing and valuable branches of knowledge which have originated from Darwin's great conception and his example in experiment and inquiry.

Metchnikoff is now devoting all his attention to the possibility of prolonging human life. The facts seem to show that if we ate and drank only what is best for us, and led lives regulated by reason and knowledge, we should, nearly all, attain to 80 or even Ioo years of age, having healthy minds and healthy bodies. We should die quietly and comfortably at the end, with much the same feeling of contentment in well-earned final repose as that which we now experience in going to sleep at the end of a long and happy day of healthy exercise and activity. Metchnikoff thinks that the causes of too early death may be ascertained, and when ascertained avoided or removed. In 1870, in a little book on Comparative Longevity, I distinguished what we may call the "possible life," or "potential longevity," of any given human being from his or her "expectation" of life. Potential longevity has been well called our "lease" of life. It is probably not very different in different races of men or individuals and is probably higher than King David thought, being 100 to 120 years, and not merely 70 years. We all, or nearly all, fail to last out our "lease" owing to accidents, violence, and avoidable, as well as unavoidable, disease; so that 70 years is named as our tenure when the injury done to us by unhealthy modes of life and by actual disease are considered as inevitable. Metchnikoff proposes to discover and to avoid those conditions which "wear down" most of us and produce "senility" and 
"death" before we have really run out our lease of life.

Human beings die most abundantly in the earliest years of life. Statistics show that at birth the chance or expectation of life is only 45 years, whilst at 10 years old you may expect to live to be 6r. At 30 you have not a much better chance-you will probably, if you are what is called a "healthy" life, die when you are 65. But if you survive to be 50 you may expect, if you have not any obvious disease or signs of "break up," another twenty years, and will probably die at 70 ; surviving to 60 , you may expect, if you are what passes for "healthy," to live to 73. Now, it is especially with regard to life after 40 or 50 years of age that Metchnikoff is interested. Those who have survived the special dangers and difficulties of youth, and have arrived at this mature age, ought to be able to realise much more frequently than thcy do something like the full "lease of life." There seems to be no reason why they should not avoid the usual rapid "senile changes" or weakness of old age, and survive, as a few actually do, to something like Ioo. The causes of "senile change" and the way to defeat their operation are what Metchnikoff is studying. Hardening of the walls of the arteries set up by certain avoidable diseases contracted in earlier life, and by the use of alcohol (not only to the degree which we call "drunkenness," but to such a degree as to make one depend on it as a "pick-me-up "), is an undoubted cause of that weakness and liability to succumb to other diseases which is so general after 50 years of age. The causes which produce hardened arteries can be avoided. Another cause of senile changes is declared by Metchnikoff, to arise from the continual absorption of poisonous substances produced by the decomposition of partially digested food in the lower bowel or large intestine. This is at present the chief subject of his study. It is to 
prevent the formation of these poisons that he has introduced the use of sour milk, prepared with the lactic ferment. Since the Cambridge celebration he has been in London in order to examine the condition of certain patients from whom a distinguished English surgeon has found it necessary to remove the "large intestine." Metchnikoff wishes to ascertain what bacteria, poisonproducing or other, are present in these patients, and what is their general chemical condition now that this poisonproducing part of the digestive canal has been taken from them.

In Paris, Metchnikoff has some very interesting experiments in progress with bats. He uses the large tropical fruit-eating bats, or "flying foxes." They have a very short intestine, and very few bacteria and of very few kinds are to be found in its contents. On the other hand, there are as many as thirty distinct kinds of bacteria producing putrefaction or other chemical change in the digestive canal of man-and their quantity is gigantic. They pervade the whole contents of the human digestive canal by millions. By properly feeding the flying foxes in his laboratory in Paris Metchnikoff has actually succeeded in getting rid of all bacteria from their digestive canal, so that he now has adult mammalian animals, not very remote from man in their structure, food, and internal chemistry, which are absolutely free from the intestinal parasitic bacteria which he supposes to cause poisoning and senile changes in man. It is obvious, without pursuing the matter into further detail here, that Metchnikoff is now in a position to test his views as to the action of particular kinds of bacteria-he has animals which are free from them. He can make an experiment, keeping some of his bats still free from bacteria and causing some to be largely infected by this or that kind, and he can compare the result in regard to the health and chemical 
condition of the animals. So, too, the patients from whom the lower intestine has been removed may very probably furnish him (through his assistant who remains in London) with important facts for comparison with the condition of persons who have not been deprived of this part of the digestive apparatus.

I have given this sketch of what my friend is doing in order to furnish some notion of the kind of investigation which he pursues. He does not expect to extend the "lease" of human life, but by ascertaining in a definite scientific way the true rules of internal and external "hygiene" he does hope to give mankind an increased "expectation" of life; in fact, to enable a vastly larger number of men and women to enjoy that lease to the full, and to die without disappointment and regret, even with contentment and pleasure, at the end of it.

Metchnikoff was in Russia in the spring of 1909 , and spent a day with Tolstoi. They were "fêted " and photographed together, the greatest artist and the greatest scientist of Russia. Tolstoi is $8 \mathrm{r}$ years of age. He took Metchnikoff out alone for a drive in his pony-cart so as to talk with him without interruption. "What do you think of life?" was the first question he asked, and one which it took my friend some time to answer. In regard to vegetarianism the two great men did not agree. When Metchnikoff declared that there was less cruelty on man's part in killing wild animals to eat them than in leaving them to die by the tooth and claw of predaceous animals or from starvation, Tolstoi observed that that was argument and reason, and that he paid no attention to them; he only guided himself (he said) by sentiment, which he felt sure told him what was good and right! He was, however, deeply interested in an account of the cannibalism of savage races of men, concerning which he seemed to be quite uninformed. $\mathrm{He}$ also was profoundly interested in 
Metchnikoff's view that Goethe, in the second part of Faust, is chiefly bent upon depicting the persistence of the amorous passion in old age-of which Goethe himself was an example-and Tolstoi declared that this gave a new meaning to the poem, which he had always hitherto found dull and unintelligible. But when Metchnikoff described in glowing words the joy and even rapture with which man will hereafter welcome the repose and mystery of death, having completed a long and healthy life of some hundred years, Tolstoi declared that this was indeed a fine conception, although it was entirely subversive of his own notions as to the significance of life and death. Tolstoi also stated that he had written his stories rapidly and without effort, but that his essays on morality and religion had cost him great labour; and, further, that he could not now remember the former, though the latter still were developing and incessantly occupied his thought.

It was admitted with regret by Darwin that he ceased in middle age to care for poetry and art, though there seems to be no doubt that he mistook fatigue and preoccupation of mind for a real change in taste and power of appreciation. It is interesting to place beside this the case of the great literary artist, Tolstoi, who not only frankly confesses that he refuses to be guided by reason and follows sentiment, but is also profoundly ignorant upon all the most ordinary topics of human life outside his own village, and of all Nature and her workings. Would Tolstoi have been a greater or a smaller artist if he had had a larger knowledge of the things that are? Was Darwin's great scientific achievement really related to an innate indifference to what is called "poetry"? I will not now discuss the matter, but I am convinced that so far as natural gift is concerned, the keenest scientific capacity is not only compatible with the fullest sensibility to art and with the power of poetical vision and expression, 
but is often accompanied by them; and, further, that the work of an artist, if he is a great artist, cannot be hampered by knowledge. It is only the small talent or the feeble genius that can be paralysed rather than developed by the fullest experience and the widest knowledge. Necessary incompatibility of mental qualities has no place in this matter; what has led to the erroneous assumption that it has, is the excessive exercise by exceptional individuals of certain powers-a specialism necessary for effort and success, but deliberately chosen, and not due to an inborn one-sidedness. 


\section{VII}

\section{THE LAND OF AZURE BLUE}

THE Côte d'Azur whither many of my readers will

1 be travelling-in thought, if not in reality-about Easter time, is well named the Land of Azure Blue, for it is the blueness of the sea, of the sky, and of the distant rocks and mountains, as well as much of the vegetation, which is when the sun shines, its special charm. And although one has some wet and some cloudy days, yet the sun does shine there with a strength and brilliancy not to be enjoyed in the early part of the year on the Atlantic and North Sea coast. This tract of country, more commonly known to English people as the Riviera, has very special meteorological conditions owing to its position as the narrow strip of shore-line existing between the vast mass of the Western Alps and the Mediterranean Sea. It is warmed by the sea, and lies too close under the mountains to be caught by any winds from the north, and at many points is also effectively protected from both east and west winds by rocky spurs of the great mountain chain.

The Riviera is a constant source of delight to those who love flowers and beautiful vegetation of all kinds. But few of its visitors appreciate the fact that it is really from end to end one big garden, cultivated for ages by its inhabitants, and full of plants introduced by man 
which at present seem at first sight to be characteristic natives of it, but are, in reality, quite distinct from its primitive vegetation. This primitive vegetation is now represented only in what is locally called the "maquis"what we should, perhaps, term the "scrub" or "bush" in English. It comprises some pines, the juniper, the lovely rock roses, balsams, rosemary, the giant heath (bruyère), from which our briar-root pipes are made, the larger thyme, the myrtle, the rose of Provence, two kinds of lavender, and many aromatic plants with grey hairy leaves, and often provided with sharp thorns as additional defences against browsing goats. The delicious perfumes of these hardy inhabitants of the dry, rocky grounds, where little or no grass can flourish, are developed by them as a protection against browsing animals, who cannot tolerate much of these pungent volatile oils, although mankind extracts them and uses them in the manufacture of such scents as eau-de-Cologne and also in cookery.

Many a visitor to the Riviera never strays from the cultivated fields and roadways into this scrub-land. The olive tree, which forms so prominent and beautiful a feature in the panorama of gardens which unrolls itself as we steam or drive along the coast from Toulon to Mentone and from Mentone to Genoa and Spezzia, is not a native plant; it was introduced in prehistoric times, and has been again and again re-established by emigrants from Italy; but it was brought to Italy from the East. It is astonishing how many of the cultivated trees of the Riviera have the same kind of history-the vine came from India in prehistoric times, the fig tree more recently from Persia, the lemon from India, the orange and the peach tree from China. All of them were introduced in very ancient times to the eastern parts of the Mediterranean basin, and so gradually were carried to the shores of the Ligurian sea, 
and would die out here were they not to a certain extent under the care of ownership.

The so-called "mimosa," so abundant here, with its pretty, sweet-scented, yellow blossom, is an Australian acacia, only introduced some sixty years ago; whilst the eucalyptus-a most picturesque and effective addition to the landscape-is a still later introduction from Australia. The cypress, that darkest and most shapely of conifers, long lines of which proclaim to the traveller as he passes Avignon his arrival in the true "South," is not a native of these parts, although it flourishes in suitable situations. It was introduced in mediæval times from the East. So, too, the palms, though some have been cultivated for centuries, have been largely imported from extra European localities in the last century. There is a native European palm. It is a kind of fan-palm, and grows here. I have gathered it in Sicily. It does not " rear its stately head" more than a foot from the ground, and is known to botanists as Chamorops humilis. The gigantic Mexican agave and the prickly-pear cactus were introduced in the seventeenth century from the New World, though, according to Sir Herbert Tree's scenery, they were growing at Cape Miseno in the time of Antony and Cleopatra! Bamboos of many kinds have been introduced here from the Far East, and flourish exceedingly.

The orange tree was brought from India (whither it was carried from China) and established in Southern Europe in mediæval times, though known to the ancient Greeks and Romans. There are as many as 120 different varieties of the orange tree now cultivated on the shores of the Mediterranean, including, besides those which are valued for their sweet juicy pulp, those which furnish bergamot oil and similar aromatic products. The "issue pea" of old apothecaries, which was bound into a cut made in a patient's flesh for the purpose of producing 
inflammation and suppuration, with the notion that such treatment was beneficial, was a minute unripe orange dried, and, no doubt, to some extent, antiseptic.

Besides the introduced trees, we find, in ground which has been more or less under cultivation, and not, therefore, of the nature of the "maquis," or scrub-land, some beautiful plants, such as the narcissus, iris, and various lilies. One very small and graceful tulip is, I believe, regarded as native to the soil, but a magnificent crimson tulip, as large as the varieties cultivated in English gardens, which I have found abundantly in open park-like land under olive trees at Antibes, is said to have been introduced from Persia in the Middle Ages, and to have taken kindly to the Riviera. It is the Tulipa oculus solis. In the same locality were growing many brilliantly coloured "stellate" anemones.

There is, of course, a third group or "lot" of plants on the Riviera, which consists of those brought from all parts of the world during the past century, and regularly cultivated and cared for in gardens. The climate of the Riviera enables the gardener to grow all sorts of subtropical plants in the open air, and a long list of them could be given. The wonderfully brilliant crimson creeper, Bougainvillia, covers walls by the roadways, and even the railway stations, with its rich colour at this season. A delightful book by the distinguished botanist, Professor Strasburger, describing and picturing in colours many of the cultivated as well as the wild plants of the Riviera, has lately been published (in English) at a small price.

The animals which come under the notice of those who go in search of spring sunshine to the Riviera are far less numerous than the plants. But there is one which is dear to all, although it makes such a noise for an hour or so about sunset that some people are irritated or even 
alarmed by it. This is the little green tree-frog, Fig. I, which now comes forth from its winter sleep, and assembles in thousands-guided by the "croak" or "call" which is produced by the males. The females have a very small voice comparatively. I kept two-a male and femalethrough a winter in London, and when the spring came the male terrified the household one night by unexpectedly uttering his cry-loud and sharp-to which the female replied. "Wharr! biz" is the nearest expression I can give in letters to the two sounds. After a great many evenings spent in these rhythmical declamations, the little frogs collect round pools and tanks, and at last drop from the trees into the water, and there deposit their spawn. When producing his cry the male distends the skin of his throat like a balloon. The air is driven alternately from it into the lungs and back again over the vocal chords, which vibrate with no uncertain sound. These little frogs are easy to keep in an inverted bell-jar or in a fern-case, but must be fed regularly with flies and spiders, which they catch by a sudden dab of the tongue at the moment of alighting from a long leap on to the glass where the insect is crawling. They can hold on to smooth glass or leaves by means of their sucker-like toes (Fig. I).

The colour of the upper surface of the South European tree-frog is a most vivid and smoothly laid-on grass-green. Occasionally the colour becomes altered to a brownish purple, but returns after a day or two to its usual bright green tint. A great rarity is the blue variety of this frog - the enchanted Prince of the Côte d'Azur-blue as the sky and the sea around him-the true genius loci. I obtained one a few years ago at Mentone, and kept it alive for three years in London. Its blue was the blue of the forget-me-not or the finest turquoise. When it died (I believe of old age, and not from discomfort or disease) I examined its skin very carefully with the microscope 


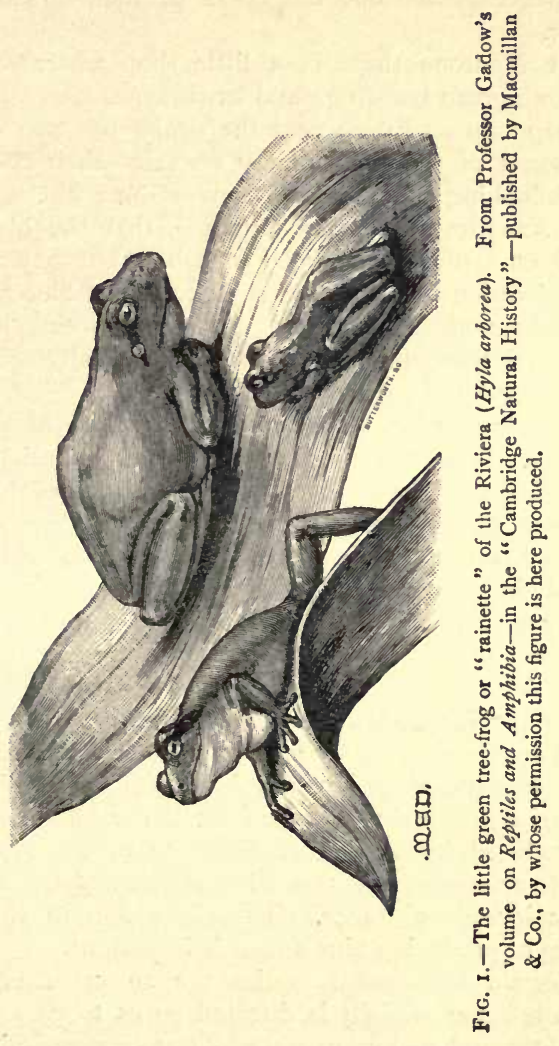


and compared it with that of the ordinary green tree-frog in order to make out the cause of their difference in colour.

At Mentone there is a little shop where one may purchase green tree-frogs and ornamental cages in which to keep them. Every year the dealer has two or three specimens of the blue variety on sale-their backs and heads looking like bits of turquoise-blue kid. Visitors have sometimes wrongly supposed that the blue frogs had been artificially changed in colour, but they are real, natural varieties. A similar substitution of blue for green has been noticed as a rare variation in other kinds of frogs and toads in other countries. It really consists in a suppression of yellow pigment.

The interesting thing about the colour of the little tree-frogs is that we find, on careful examination of the skin of a dead specimen with the microscope, that there is no green nor yet any blue "pigment" present in it. I found, on examining the blue specimen which died after living three years with me, that there is only black pigment overlaid by a colourless, semi-transparent layer of skin. In this outer skin in the ordinary green specimens there is scattered a quantity of excessively minute yellow particles, which, mixed with the blue, produce the green appearance. The fact is, that the wonderful "dead" turquoise-blue of the blue frog is a colour-effect similar to that of the blue sky and the blue of the human eye. It is produced by a peculiar reflection of the light from minute colourless particles, without the assistance of any blue-coloured substance. The distinction of these two modes of producing blue colour is important.

Certain transparent bodies are so constituted that when a beam of light is directed so as to pass through them, the red, yellow, green, and purple rays which exist in colourless sunlight are stopped, and only the blue 
rays come through. Such a body is blue copperas, or sulphate of copper; another is methyl blue, one of the aniline dyes; another is pure water, which gives only a slight advantage to the blue rays, so that the light must pass through a thickness of 30 feet or more before the blue tint is obvious. Thus, part of the blueness of the Côte d'Azur is accounted for-namely, the blueness of the sea when the sunlight is strong and is reflected from the white rocks and sand lying 30 feet to 100 feet below the surface of the water.

There are, of course, other self-coloured transparent bodies which allow only rays of one colour to pass. Thus, blood-red, or hæmoglobin, the pigment of the blood, allows chiefly red rays to pass through it. Yellow rays only pass through a solution of saffron or of chromic acid; green only or chiefly through green copperas (sulphate of iron) or through leaf-green or chlorophyll. Colour is very generally due in natural objects to such transparent bodies which absorb or stop all the coloured rays of light as it passes through them, excepting those of one tintor, to be more correct, nearly all except those of one tint.

But the blue of the blue frog and a great deal of the blue in nature is due to another cause. If you are a smoker, or the friend of a smoker, watch the fine curling lines of smoke ascending from a cigar when it is being consumed in bright sunshine. You will see that it has a blue, even an azure blue, tint as the sunlight falls upon it. But if you let the smoke get between the sun and your eyes you will notice that the little curling clouds are no longer blue, but reddish-brown, in appearance. The smoke is not a transparent blue; looked at as a transparent body, it is brown! Further, when the smoke has passed into the smoker's mouth and is ejected after remaining there for a few seconds, the cloud no longer looks blue, even when the sunlight falls on it and is 
reflected from it to your eye. It is now opaque white or colourless, with, perhaps, a faint tinge of blue. This change is due-as was shown by the experiments of the late Professor Tyndall upon a variety of clouds and vapours - to the cooling of the smoke and the increased size of the floating particles which coalesce as the temperature falls. The larger particles reflect white light, and the cloud is no longer blue. A cloud formed by the finest particles gives the strongest blue to the light reflected from it, and it is to this property of the finest particles of water-cloud floating in our atmosphere that the blue colour of the sky is due.

No doubt the question arises, "Why do clouds of the finest particles reflect a predominant amount of blue light rather than yellow or green or red?" That question is answered by mathematicians in accordance with what is ascertained as to the nature and properties of light, but it would require a long treatise to put those matters even in outline before the reader. We may in the meanwhile accept the conclusions of the physicists, and interest ourselves in seeing how they apply to some of the concrete facts about colour in Nature.

There are other instances of "blueness" due to the reflection of light from a cloud of excessively minute particles besides that of the azure sky and the blue, curling smoke of a wood fire. A familiar instance is the blueness of translucent bodies, such as the "white" of a boiled plover's egg, especially when a bit of it is placed on a dead-black ground. The bluish appearance of watered London milk is another instance. These bodies look blue owing to the fine, colourless particles suspended in them, which act on light in the same way as do the fine particles of newly-produced smoke. Another very interesting case is the blue colour of the iris of the eye of man and other animals. It is not due to any blue pigment, but to a 
reflection from fine particles in the translucent, but turbid, tissue of the iris overlying the dark, black chamber of the eye. White geese and white cats frequently have blue eyes, the blue being thus produced. The only pigment which occurs in the human eye is a brown one, which gives a colour varying from amber yellow to very dark brown, almost black, according to the quantity present. When a very little of it is present it gives, in combination with the blue appearance of the unpigmented iris, a green tint, so that green eyes owe their colour to the same combination of causes as does the green skin of the little tree-frogs, or "rainettes."

No solvent will extract any pigment from the skin of the blue frog-nor by the finest trituration can one obtain any coloured particles from it; only fine black granules can be separated. Alcohol removes the yellow pigment from the skin of a green tree-frog (killed, of course, for the experiment), and for a minute or two the skin becomes blue when its yellow pigment is thus removed by immersion in spirit; but it rapidly becomes a dull greyish-brown in colour, and so remains; the green cannot be preserved in spirit-specimens. It is not fully explained how such a uniform "dead" blue is produced by the reflection of light from fine particles, as that observed in the blue frog's skin.

It appears that the blue and the green colour in the feathers of birds is in most, if not all, cases produced in the same way as the blue and green of the tree-frog's skin. It would be interesting were it found possible to produce a full dead-blue colour by experimentally placing a coat of a translucent but turbid colourless medium on a deadblack plate. This, however, has not been done as a deliberate experiment. It is, however, recorded that Goethe was delighted to find what he considered to be a confirmation of his theory of colour when a friend showed 
him an oil-painting of a gentleman in a black coat which when wetted with a sponge turned bright blue. The picture had been recently "restored," and the varnish on the black coat was not "dry." It was precipitated by the water from the sponge, mixing with the spirit which held it in solution. A fine colourless cloud was thus produced overlying the black paint of the coat, and, as in the case of the cerulean frog, a dead-blue colour, due to reflection of the light by the fine particles, was the result. Some friendly physicist might repeat this experiment and study the matter in detail. The red, orange, and yellow colours of birds' feathers are produced by pigments which are either insoluble or only soluble with great difficulty in fluids of the nature of ether. There is, however, an exception in the case of the African birds called Turacous, or Plantain-eaters. These birds have some large quillfeathers in the wing of a rich crimson colour. This splendid red pigment can be washed out of the feathers by water which is slightly alkaline, and a fine blood-red solution is obtained. Why this curious exception exists we do not know. The extracted colour is found to contain the element copper as one of its chemical components. Plantain-eaters kept in cages have sometimes washed all the colour out of their feathers owing to the water supplied to them for bathing and drinking having become foul and ammoniacal, and thus capable of dissolving the red pigment.

The cultivation on the Riviera of flowers for sale as "cut flowers" in Paris, London, and Berlin, in the colder months of the year, is now an enormous business, bringing many thousands of pounds yearly to the small gardeners around Hyères, St. Raphael, Nice, and Mentone. Roses, violets, carnations, "mimosa" of various kinds, anemones, lilies, and narcissus are sent literally in tons by quick trains several times a week from these realms of sunshine 
to the dreary North. The commencement of this trade was due to the suggestion made some fifty years ago by Alphonse Karr, the French poet and journalist, who had a beautiful garden of his own at St. Raphael, and found that he could produce flowers in profusion through the winter. Two years ago I visited this garden (which now belongs to a French painter) at the beginning of April, and found it full of interesting flowers and shrubs, enormous bamboos, palm trees, some twenty different "mimosas," eucalyptus of several species, camellia trees, and rose-bushes in quantity.

The influence of man on the vegetation of a favoured locality like the Riviera is more striking than in the North. But it is worth remembering that the most familiar tree in England-the common elm-is not a native, but introduced from South Europe. Our native elm is the wych-elm, or mountain elm-a much handsomer tree, in the opinion of many, than the so-called "common elm." There are doubts as to whether both the spruce and the larch were not introduced by man at a very remote time, so that the Scotch fir would be our only aboriginal pine. The oak, beech, birch, ash, hawthorn, poplar, and alder are undoubted native English trees. The holly-oak or evergreen oak, the sycamore, plane-tree, sweet chestnut, horse chestnut, walnut, and probably the lime or linden tree have been introduced by migrating men at various periods into our islands. With the exception of rye and oats none of the plants which we cultivate for food are derived from our own wild plants, and none of our domesticated animals have been produced from native wild kinds. 


\section{VIII}

\section{FRESH-WA'TER JELLY-FISHES}

V OST people nowadays know a jelly-fish when they product of the sea-one sees them washed up on the seashore, soft discs of transparent jelly of the size of cheeseplates (Fig. 2). They have a mouth in the centre of the disc, often at the end of a depending trunk, like the clapper of a bell. Some have tentacles, sometimes yards long, which sting like nettles. They also have eye-spots, an internal system of canals and muscles which enable them to swim by causing the edge of the disc or bell to contract and expand in alternate strokes. There are hundreds of kinds of marine jelly-fish varying in size from a sixpence to that of a dinner table, and until twenty-five years ago none were known to live in ponds, lakes, or rivers. Although they often are carried up estuaries, and may stay for a time in brackish water, or even in fresh water, none were known which really lived and bred in fresh water. They were regarded, as are star-fishes and seaurchins, as distinctively marine, and debarred by the delicacy of their watery jelly-like substance from tolerating the change from sea water to fresh water as a permanent thing. All fresh-water animals-fishes, shell-fish, cray-fish, worms, and polyps-are derived from closely similar marine animals, are in fact sea-things which have suffered a change, and been able to stand it 
These being our preconceptions about jelly-fish, great was the excitement when, in 1880 , hundreds of beautiful little jelly-fish were suddenly discovered briskly expanding and contracting, rising and sinking in the water of a

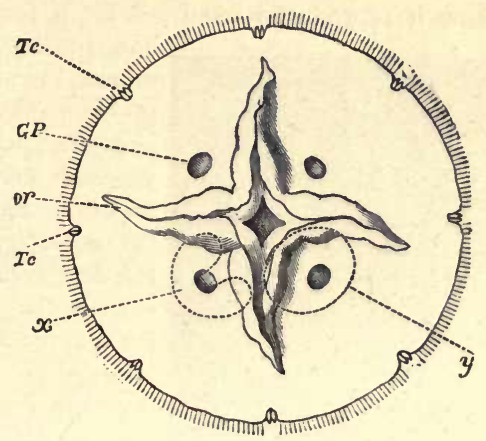

FIG. 2. - The common jelly-fish (Aurelia aurita) one-third the natural size; or, one of the four arms or fleshy tentacles surrounding the diamond-shaped mouth; $T c$, one of the eight eye-bearing tentacles at the edge of the disc; $G P$, opening of one of the four sub-genital pouches, which bring sea-water close to the ovaries and spermaries, which, however, do not open into these pouches ; $x$ and $y$, outline of the sub-genital pouches seen through the jelly.

large fresh-water tank in the middle of London (Fig. 3). You never know who or what may turn up in London. A badger, a green parakeet, a whale, an African pigmy, an Indian scorpion, and a voice worth ten thousand a year, have all, to my knowledge, been stumbled upon unexpectedly at different times in the highways of London. A new jelly-fish was perhaps one of the least expected "casual visitors." It was found in the large tank four feet deep in which the great tropical water-lily - the Victoria regia-and other tropical water plants are grown 
in the Botanic Gardens, Regent's Park. It came up by hundreds every year for some ten years after its first appearance, dying down in six weeks or so each season.

All the specimens were males, and the puzzle was to find out how it reproduced itself. After a few seasons

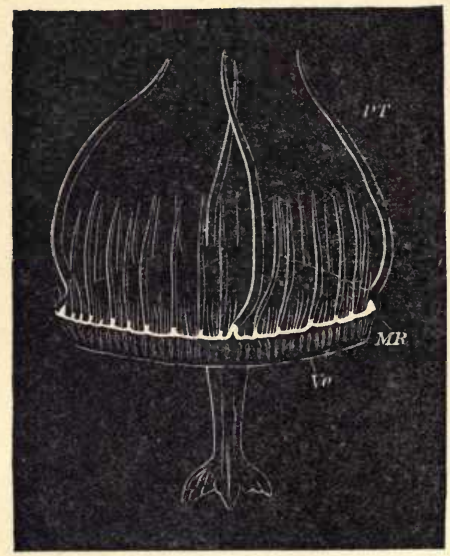
dium) enlarged four times linear measurement, as it is seen dropping through the water in a glass jar. $P T$, one of the four principal tentacles. $M R$, the margin of the disc. $V e$, the delicate muscular frill or velum.
FIG. 3.-The fresh.water jelly-fish (Limnocohad passed I determined to solve this problem. I made the guess that perhaps the jelly-fish were budded off from a fixed weedlike polyp growing in the depths of the tank - as is the case with many of the marine jelly-fishes. I remember that one leading member of the council, which still presides over the destinies of the Botanic Gardens, confided to me in a hushed whisper his belief that Providence created this new jellyfish year by year in the tank in honour of the august patronness of the Botanic Society-Her Royal Highness the Duchess of Teck. I was obliged to make an end of this flattering theory when I discovered, after long searching with my assistant-attached to the rootlets of floating water weeds a minute three-branched polyp (Fig. 4), from which, as we subsequently were able to observe, the jelly-fish 
were pinched off as tiny spheres about one-sixteenth of an inch in diameter. No females of this jelly-fish were ever discovered. The polyps lived on from year to year, and budded off each season a swarm of pretty but futile male jelly-fish. They ripened and died on attaining a diameter somewhat less than that of a shilling. There were many most interesting points made out as to their structure, mode of feeding, and growth. You could keep them in a tall glass jar supported over a small gas-jet (they lived best at a temperature of $80^{\circ} \mathrm{Fahr}$.), and they would swim up by a series of strokes to the top of the water, and then drop like little parachutes through the eighteen inches of depth to the bottom-taking in water-fleas and such food on the way - and immediately would start upwards again. I used to take them alive in my pocket corked up in a test-tube to show to friends.

After they had disappeared from the tank in Regent's Park (owing to some unhappy cleaning of the tank) they suddenly, in 1903, appeared - it seems incredible - at Sheffield! Then they briefly showed up in 1905 at

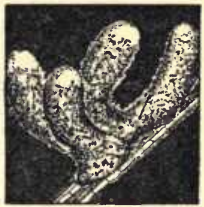

FIG. 4.- Four of the minute club-shaped polyps adhering to a root-fibre of a water-plant. The rounded end becomes nipped off and swims away, free, as a young elly-fish. Munich, and at Lyons had been captured in 190Ialways in a tepid water-lily tank! We never could make out where they came from originally. Of course, the polyp must have been brought into the tank with some bundle of water plants from a tropical lake or river, but we never had any indication as to when or which.

Since the days of the fresh-water jelly-fish of Regent's Park, which was called (a name, but why should it not have a name?) Limnocodium Sowerbii-a jelly-fish of 
about the same size (Fig. 5) but very different in shape and tentacles-was discovered in the great African freshwater lake Tanganyika-in enormous numbers, and was named Limnocnida Tanganyika. Only five years ago the same jelly-fish was discovered in the Victoria Nyanza, and a little earlier in backwaters of the Niger. It is a

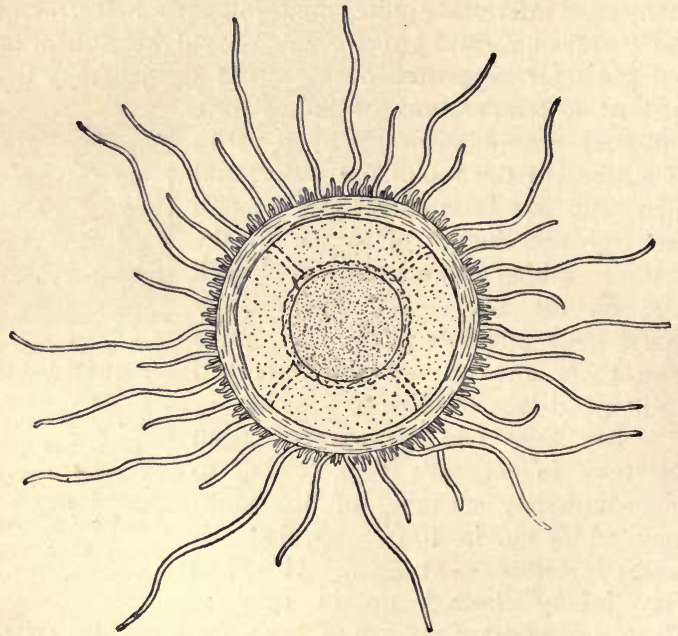

FIG. 5.-The African fresh-water jelly-fish (Limnocnida) found in Tanganyika, Victoria Nyanza, and the Niger.

curious and significant fact bearing upon the history of these three areas of fresh water connected with the three greatest African rivers-the Congo, the Nile, and the Niger-thatthe same little jelly-fish is found in all of them.

And now we have just been reminded of Limnocodium, the Regent's Park jelly-fish, from a remote and unexpected 
source. A thousand miles up the Yang-tse-Kiang River, in China, in the province of Hupi, the Japanese captain of a river steamer, plying there and belonging to a Japanese company, captured ten jelly-fish in the muddy waters of the river. He brought them home, preserved, I suppose, in alcohol or formalin, and they have been described by Dr. Oka, a Japanese zoologist of Tokio, in a publication bearing the Latin title Annotationes Zoologica niponenses, issued in December 1907. European sea captains have not rarely been ardent naturalists, but I think the Japanese is the first captain of a river steamboat who has discovered a new animal on his beat. I have not heard of Mississippi steamboat captains amusing themselves in this way-other rivers, other tastes.

Dr. Oka describes the jelly-fish thus brought to him as a Limnocodium, differing in a few details from that of Regent's Park, so that he distinguishes this Chinese species as Limnocodium Kawaii, naming it after the naturalist captain, who must have a rare taste for picking up strange and new things, and a rare goodwill in bringing them home with him. So here is another fresh-water jelly-fish, for it is not the same as the Regent's Park one, though closely like it. Possibly Limnocodium is an Asiatic genus, and the original Sowerby's Limnocodium will be found in another Chinese river. But it may prove to be South American, as is the water-lily Victoria regia.

A very small fresh-water jelly-fish was found some twelve years ago-in 1897-in the Delaware River at Philadelphia, United States, and was lately described by the well-known naturalist, Mr. Potts. It was budded off from a very minute polyp resembling that found in the Regent's Park, but the jelly-fish was totally different from Limnocodium. Only four or five specimens of this jelly-fish have ever been seen, and the Philadelphian naturalists ought certainly to look it up again. 


\section{SCIENCE FROM AN EASY CHAIR}

An account of the Philadelphian jelly-fish and of other fresh-water jelly-fishes, with illustrative plates, will be found in the Quarterly Journal of Microscopical Science, 1906. Mr. Charles Boulenger has, in the same Journal, 1908, described yet another fresh-water jelly-fish from the Fayoum Lake in Egypt. 


\section{IX}

\section{THE STORY OF THE COMMON EEL}

THOUGH the Scotch Highlanders are said to have a

1 profound objection to eating eels on account of the resemblance of these fish to snakes (not a very good reason, since the quality and not the shape of what one eats is the important thing), yet eels have been a very popular delicacy in England in past days. Eel-pie Island, at Richmond, is known to most Londoners, and eel-pie shops were familiar in London less than a century ago. A good Thames eel is still appreciated by the few people who nowadays take some small amount of intelligent interest in what they eat. Abroad, eels are still popular. Eel-traps are still worked in the rivers. In such districts as the flat country, on the shores of the Adriatic, near Venice, millions of young eels are annually "shepherded " in lagoons and reservoirs, and reared to marketable size. The inland eel-fisheries of Denmark and Germany are carefully regulated and encouraged by the Government in those States.

The fact is that railways, ice-storage, and steamtrawling have, in conjunction, revolutionised our habits in regard to the use of fish as a daily article of diet. Fresh-water fish are now almost unknown as a regular source of food in the British Islands. The splendid fish of the North Sea, the Channel, and the Atlantic coast 
have pushed them out of the market. Thirty-eight years ago, when I was a student in Leipzig and Vienna, "baked carp "was the only fish to be had in the dining-rooms we frequented. Once a week there were fresh haddock, for those who fancied them, in the celebrated Auerbach's Keller. Now the railway and packing in ice have brought North Sea fish to the centre of Europe, and created a taste for that excellent food. Even on the Mediterranean at Nice, I lately saw North Sea turbot, soles, and haddock lying on the marble-slabs in the fish market side by side with the handsome but small bass, mullet, gurnards, and sea-bream of the local fishery, and the carp, pike, trout, and eels of the fresh waters of the South of France.

Nevertheless the eel-the common fresh-water eelis still valued on the Continent, as is proved by the fact that the German Imperial Government has recently sent an important official of the Fisheries Department to Gloucester in order to make extensive purchases of the "elvers," or young eels which come up the river Severn in millions at this season. The purpose of the German fisheries officials is to place many hundred thousands of these young eels in German rivers which are not so well supplied by natural immigration as is the Severn, and by so doing to increase the supply of well-grown eels hereafter in the river fisheries of North Germany.

This interesting practical attempt to increase the supply of eels in Germany will be further appreciated when I relate what has been discovered within the last twenty years as to the reproduction, migrations, and habits of the common fresh-water eel. It has been known, time out of mind, that in the early months of every year millions of young eels a little over two inches in length, called "elvers" in English and "civelles" in French, come up the estuaries of the rivers of Europe 
in a dense body. They are so closely packed together as the narrower parts of the stream are reached, that thousands may be taken out of the water by merely dipping a bucket into the ranks of the procession. I obtained a few thousand of these "elvers" lately from the Severn and placed them on exhibition in the central court of the Natural History Museum in London. The Anglo-Saxon name "eel-fare" is given to this annual march or "swim" of the young eels from the sea to the fresh waters.

Though riverside folk have never doubted that the elvers are young eels which have been hatched from spawn deposited by parent eels in the sea, and are "running up" to feed and grow to maturity in the rivers and streams inland, yet country folk away from the big rivers have queer notions as to the origin and breeding of eels. They catch large, plump eels a couple of feet long in stagnant ponds hundreds of miles from the sea, far from rivers, and more than a thousand feet above the sea-level. They have no notion that those eels originally "ran up" as little eels from the sea, nor that many of them make their way across wet grass and by rain-filled ditches back to the rivers and to the sea when they are seven years old. But that is now known to be the fact. Just as there are fish, like the salmon, which "run down" to the sea to feed and grow big and "run up" to breed in the small pools and rivulets far from the river's mouth, so there are other fishes, of which the eel is one, which run up to feed and grow and run down to breed-that is to say, to deposit and fertilise their eggs in the depths of the ocean.

Fishermen who work river-fisheries for eels (far more valued abroad than in England) distinguish "yellow eels" and "silver eels" (see Plate I. opposite title page). We used to distinguish also snigs and grigs, or narrow-nosed 
and broad-nosed eels (probably males and females). The remarkable fact, admitted by both fishermen and anatomists, was that you could not really tell male from female, nor, indeed, ever find an eel (that is, a common eel, as distinguished from the much larger and well-known conger eel) which was ripe, or, indeed, showed any signs of having either roe or milt within it. A popular legend exists that eels are produced by the "vivification" of horse-hair. Occasionally in summer a long, black, and very thin threadworm (called Gordius by naturalists) suddenly appears in great numbers in rivers, and these are declared by the country-folk to be horse-hairs on their way to become eels! I remember a sudden swarm of them one summer in the upper river at Oxford. Really, they are parasitic worms which live inside insects for a part of their lives, and leave them in summer, passing into the water. Fanciful beliefs about aquatic creatures are common, because it is not very easy to get at the truth when it is not merely at the bottom of a well but at the bottom of a river or of the deep sea! The fishermen of the east coast of Scotland, who think very highly of their own knowledge and intelligence, believe that the little white sea-acorns or rockbarnacles are the young of the limpets which live side by side with them, and are scornful of those who deny the correctness of what they consider an obvious conclusion!

A few years ago the Scandinavian naturalist, Petersen, showed that the "silver" eels are a later stage of growth of the "yellow" eels; that they acquire a silvery coat, and that the eye increases in size-as a sort of "wedding dress," just before they go down to the sea to breed. I owe to Petersen's kindness the coloured drawings of the heads of the yellow and the silver eel reproduced in Plate I. These silver eels are caught in some numbers about the Danish coast and river mouths, moving downwards; and Petersen has been able to distinguish the 
males from the females by finding the still incompletely formed milt and roe within the silver eels. Not only that, but one of Petersen's assistants at the Danish Biological Station has found that you can tell the age of an eel by the zones or rings shown by its scales, when examined with a microscope, just as the age of trees can be told by the annual rings of growth in the wood. Most people, even if familiar with eels, even cooks who have skinned an eel, do not know that they have scales; but they have, -very small ones. The age of other fishes has been similarly ascertained by annual zones of growth marked on the scales; and lately the age of plaice has been found to be conveniently given by zones of growth formed annually on the little ear-stones which we find in the liquid-holding sac of the internal ear. I am afraid many of my readers will be surprised to learn that fishes have an internal hearing apparatus similar to our own, also that they have olfactory organs, and, in some cases, a wellgrown tongue!

The power thus obtained of telling the age of an eel has led to the following knowledge about them, namely, that female eels do not becorne "silver" eels and "run down" before they are seven years old, and often not till eight and a half years of age, or even sometimes eleven or twelve years, when they are nearly 3 feet long. The male eel becomes "silver" (instead of "yellow") at an earlier age-four and a half years,-and rarely defers his nuptial outburst until he is seven or eight years old. The females of the same age are larger than the males; a usual size for silver females of seven years old is a little over 2 feet, and of a silver male of the same age 20 inches.

The further facts which I am about to relate as to the migration and reproduction of the common eel are of great interest. The common "yellow" eels of our ponds and rivers, as we have seen, when they are from five to 
seven years old and over, put on, as it were, a wedding dress. They become "silver" eels, and descend the rivers to the sea. There they produce their spawn. The young eels thus produced, when only 2 inches long, leave the sea. Every year they ascend the estuaries and rivers of Europe as "elvers" in enormous numbers, their procession up the rivers being known as "the eel-fare."

Some eels, shut up in moats and ponds, never escape -they become more or less "silver" and restless, but fail to get away. Others crawl up the banks in wet, warm weather, when the ponds are full to the brim, and over the meadows. They are found sometimes on their journey when they

$$
\text { "... have to pass }
$$

Through the dewy grass,"

and so to the river, and on to the marriage feast in the deep sea. The fact is, that usually eels inhabit in large numbers the rivers and streams, and have no difficulty in getting down to the sea when they are adult. Those who, as young elvers, have wandered far off into sunken ponds and reservoirs, are eccentric spirits who have lost the normal way of life; like fellows of colleges in the old days, they have cut themselves off from the matrimonial "running down," but they have compensations in quietude, abundant food, and a long life.

We now know where the silver eels go when they run down the rivers. They go into the sea, of course ; but we know more than that. It has now been discovered that they make their way for many miles along the sea-bottom -in some cases hundreds of miles - to no less a depth than 500 fathoms. In the Mediterranean they don't have very far to go, for there is very deep water near the land, and Professor Grassi found evidence of their presence in the depths of the Straits of Messina. But the eels of the rivers which empty into the North Sea and English 
Channel have much farther to go ; they have to go right out to the deep water of the Atlantic, off the west coast of Ireland. That is the nearest point where 500 fathoms can be touched; there is no such depth in the North Sea nor in the Channel. They never come back, and no one has ever yet tracked them on their journey to the deep water. Yet we know that they go there, and lay their eggs there, and that from these remote fastnesses a new generation of eels, born in " the dark unfathomed depths of ocean," return every year in their millions as little "elvers" to the rivers from which their parents swam forth in silver wedding dress. Soon, we have reason to hope, by the use of suitable deep-sinking nets, we shall intercept, in the English Channel, some of the silver eels on their way to the Atlantic deeps. They must go in vast numbers, and yet no one has yet come across them. How, then, do we know that the silver eels ever go to this 500-fathom abysm?

The answer is as follows: A very curious, colourless, transparent, absolutely glass-like, little fish, $2 \frac{1}{2}$ inches long, oblong and leaf-like in shape, has been known for many years as a rarity, to be caught now and then, one at a time, floating near the top in summer seas (Fig. 6). I used to get it at Naples occasionally many years ago, and it has sometimes been taken in the English Channel. It is known by the name "Leptocephalus." Placed in a glass jar full of sea-water it is nearly invisible on account of its transparency and freedom from colour. Even its blood is colourless. The eyes alone are coloured, and one sees these as two isolated black globes moving mysteriously to the right and the left as the invisible ghostly fish swims around. Twenty years ago one of these kept in an aquarium at Roscoff, in Brittany, gradually shrunk in breadth, became cylindrical, coloured and opaque, and assumed the complete characters of a young eel! To 
cut a long story short, these Leptocephali were found twelve years ago in large numbers in the deep water (400 fathoms) of the Straits of Messina by the. Italian

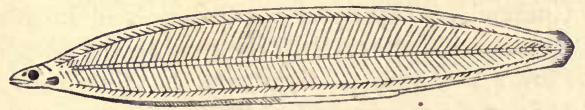

A.

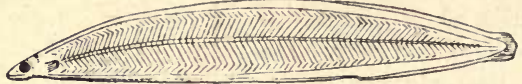

B

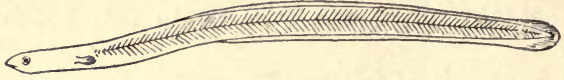

C

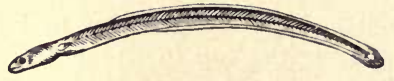

D.

Fig. 6.-Young stages of the common eel, drawn of the natural size by Professor Grassi. A, The Leftocephalus, transparent stage. D, the elver, or young eel, which is coloured, and of much smaller size than the transparent, colourless creature by the change of which it is produced. It is the elver which swims in millions up our rivers. B and C are intermediate stages, showing the gradual change of $\mathrm{A}$ into D.

naturalists Grassi and Calandruccio, and they conclusively showed that they were the young phase-the tadpole, as it were-of eels. They showed that different kinds of eels-conger eels, the Muræna, and the common eel-have 
each their own kind of transparent "Leptocephalus-youngphase," living in but also above the very deep water, in which they are hatched from the eggs of the parent eels. The Leptocephalus-young when hatched, grow rapidly, and ascend to near the surface immediately above the deep water, and are caught at depths of ten to a hundred fathoms. To become "elvers," or young eels, they have to undergo great change of shape and colour, and actually shrink in bulk-a process which has now been completely observed and described. It is not surprising that their true nature was not at first recognised. The proof that the silver eels of North and West Europe go down to the 500-fathom line off the Irish coast, in order to lay their eggs, is that the Danish naturalist Schmidt and his companions discovered there two years ago, above these great depths (and nowhere else), by employing a special kind of fine-meshed trawling net, many thousands of the flat, glass-like "Leptocephalus-young-stage," or tadpole of the common eel, and traced them from there to their entrance into the various rivers. They showed that the Leptocephali gradually change on the way landward into eel-like " elvers."

The rivers nearest the deep water, such as those opening on the west coast of Ireland and on the Spanish and French shores of the Bay of Biscay, get their elvers "running up" as early as November, December, and January. The farther off the river the farther the elvers have to travel from the deep-sea nursery, so that in Denmark they don't appear until May. Not the least curious part of the migration of the eel is the passage of the young elvers into the higher parts of rivers and remote streams. They are sometimes seen a hundred miles from the sea, actually wriggling in numbers up the face of a damp rock or wall ten or fifteen feet high, pushing one another from below upwards, so as to scale the obstacle 
and reach higher waters, like Japanese soldiers at a fort. I found them (so long ago that I hesitate to name the date -it was a year of cholera in London, followed by a great war) in a little rivulet which comes down the cliff at Ecclesbourne, near Hastings, close to a cottage frequented at that time by Douglas Jerrold. They were wriggling up in the damp grass and overflow of the driblet 150 feet above the shore, a stone's throw below. They must have come out of the sea, attracted by the tiny thread of fresh water entering it at this spot.

The Danube and its tributary streams contain no eels, although the rivers which open into the Mediterranean are well stocked with them. This is supposed to be due to the fact that the Black Sea does not afford a suitable breeding-ground, and that the way through the Dardanelles is closed to eels by some natural law, as it has been to warships by treaty. Probably, however, it will be found that the geological changes in the area of sea and land are intimately connected with the migrations of the eel, and that the eel is originally a marine fish which did not in remote ages travel far from the deep waters. Its gradually acquired habit of running up fresh waters to feed has led it step by step into a frequentation of certain rivers which have become (by changes of land and sea) inconveniently remote from its ancestral haunts. An interesting question is whether at the not very distant period when there was continuous land joining England to France and the Thames and the Rhine had a common mouth opening into the North Sea, eels existed in the area drained by those two rivers; and, if so, by what route did they pass as silver eels to the deep sea, and by what route did the new generations of young eels hatched in the deep sea travel to the Thames and Rhine. It seems most probable that in those days there were no eels in the Thames and other North Sea rivers. 
Our present knowledge of the romantic history of the common eel of our own rivers we owe in large part to the work done by the International Committee for the Investigation of the North Sea. Who would ever have imagined when he caught a wriggling eel, with a hook and worm thrown into a stagnant pool in the Midlands, that the muddy creature was some five or six years ago living as a glass-like leaf-shaped prodigy in the Atlantic depths, a hundred miles from Ireland? Who would have dreamed that it had come all that long journey by its own efforts, and would probably, if it had not been hooked, have wriggled one summer's night out of the pond, across wet meadows, into a ditch, and so to the river, and back to the sea, and to the far-away orgy in the dark salt waters of the ocean-floor, to the consummation of its life and its strange, mysterious ending ?

There are two points of interest to be mentioned in regard to the rivers Danube and Thames in connection with eels. I have trustworthy reports of the very rare occurrence of eels in streams connected with the Danube. Since the young elvers do not ascend the Danube, where do these rare specimens come from? There can be no doubt that they have made their way individually into the Danube "system" by migration through canals or ditches from tributaries of the Rhine or the Elbe. A similar explanation has to be offered of the eels which at present inhabit the Thames. I cannot find any evidence of the existence to-day of an "eel-fare"-that is, "a running up of elvers" in the river Thames. Probably about the same time as the foul poisoning of the Thames water by London sewage and chemical works put an end to the ascent of the salmon (about the year 1830), the entrance of the myriad swarm of young eels in their annual procession from the sea also ceased. The elvers were caught and made into fish-cakes in 
London before the nineteenth century, just as they are to-day at Gloucester. It would be interesting to know exactly when they ceased to appear in the Thames. A curious fact, however, is that young eels-not so small as "elvers," but from three inches in length upwardsare taken close above London even to-day. Four years ago I obtained a number of this small size from Teddington. The question arises as to whether these specimens represent just a small number of elvers which have managed to swim through the foul water of London and emerge into the cleaner part of the river above. This is improbable. It is more likely that they have come into the Thames by travelling up other rivers such as the Avon-which are connected by cuttings with the Thames tributaries. But it certainly is remarkable that eels of only three inches in length-and therefore very young-should have managed to get not merely "into" the Thames (to the upper parts of which no doubt many thus travel and remain during growth), but actually "down" the Thames so far in the direction of its tidal water as is Teddington lock. The specimens from Teddington were placed by me in the Natural History Museum. 


\section{$\mathrm{x}$}

\section{MODERN HORSES AND THEIR ANCESTORS}

THE ever-increasing development of motor traffic leads to speculation as to what is to be in the immediate future the fate of the horse. What is its history in the past?

It is in nearly all cases a matter of great difficulty to trace the animals and plants which mankind has domesticated or cultivated to the original wild stock from which they have been derived. Lately we have gained new knowledge on the origin of the domesticated breeds of the horse. It is generally agreed that the Mongolian wild horse represents the chief stock from which the horses of Europe and those conveyed by Europeans to America were derived. This wild horse was formerly known as inhabiting the Kirghiz steppes, and was called the Tarpan. It became extinct there some seventy years ago. The natives of that district asserted that the pure breed was only to be met with farther East in the Gobi Desert of Central Asia, The Tarpan itself showed signs of mixed blood in having a mouse-coloured coat, which is a sure indication amongst horses of cross-breeding. Prevalsky, a Russian traveller, was the first to obtain specimens of the pure-bred wild horse of the Gobi Desert, which still exists. Live specimens have been brought to Europe, and some are in the possession of the Duke of 
Bedford. A female is mounted and exhibited in the Natural History Museum, and also a skeleton and skulls. Prevalsky's horse, or the Mongolian wild horse, is of small stature, standing about twelve hands at the shoulder. The root of the tail is short-haired, the mane short and upright, without forelock. The body colour is yellow dun, the mane and tail black, as well as the lower part of the legs, and there is a dark stripe down the back. The muzzle in pure-bred specimens is white. The head is relatively large and the muzzle thick and relatively short. A very decided character is shown by the great size and relative length of the row of cheek-teeth, it being onethird larger than the same row of teeth in a Dartmoor pony of the same stature.

A very interesting fact, which goes a long way to establish the view that the European domesticated horse is derived from the Mongolian wild horse, comes to us in a most striking way from some of the most ancient records of the human race. In the South of France the contents of caves formerly inhabited by men have been dug out and examined with increasing care and accuracy of late years, though first investigated fifty years ago. Similar caves, though not so prolific of evidences of human occupation, have been explored in England (Kent's Cavern at Torquay, and others). The astounding fact has now become quite clear that these caves were inhabited by men of no mean capacity from 50,000 to 250,000 years ago, when bone harpoons, flint knives, flint scrapers, and bone javelin-throwers were the chief weapons in use, when these islands were solidly joined to the European continent, when a sheet of glacial ice, alternately retreating and extending, covered the whole of Northern Europe, and when the mammoth, rhinoceros, hyena, lion, bear, bison, great ox, horse, and later the reindeer, inhabited the land and were hunted, eaten, and utilised for their 


\section{MODERN HORSES AND THEIR ANCESTORS 79}

bone, tusks, and skin by these ancient men. I revert to this subject in a later article (page $37 \mathrm{r}$ ), but would merely say now that it is all as certain and well-established a chapter in man's history as that of the ancient Egyptians, who are really quite modern (dating from 8000 years at most) as compared with these cave-men of 50,000 years ago, and the even earlier races which preceded them in Europe.

The bones of the animals killed and eaten by the cave-men are found in some cases in enormous quantities. In one locality in France the bones of as many as 80,000 horses (which had been cooked and eaten) have been dug up and counted! The most wonderful and extraordinary thing about these cave-men is that they carved complete rounded sculptures, high reliefs, low reliefs, and lineengravings on mammoth's ivory, on reindeer horn, on bones, and on stones - the line-engravings being the latest in date, as shown by their position in the deposits on the floor of the caves, which are often as much as twenty feet or thirty feet in thickness! Not only that, but these carvings are often real works of art, extremely well drawn, and showing not mere childish effort but work which was done with the intention and control of an artist's mind.

An immense number of these carvings are now known. I have before me one of the most recent publications on the subject-a series of plates showing the carvings collected from caves in the Pyrenees, the Dordogne, and the Landes by M. Piette, who recently died. I have examined his collection and others of the same kind in the great Museum of St. Germain, near Paris. We have in London some of the earlier collections, and especially that of the Vicomte de Lastic, to purchase which my old friend Sir Richard Owen journeyed to the Dordogne in the winter of I 864. Many animals, as well as some human beings (Fig. 7), are represented in these carvings - the 
mammoth itself, carved on a piece of its own ivory, is among them, and a good many represent the horse (Fig. 8). Now it is a fact that the carvings of the horses of that period undoubtedly represent a horse which is identical in proportions, shape of head, mane, and tail,

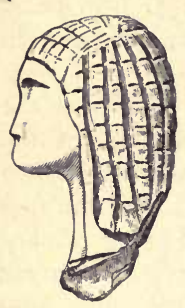

with the wild Mongolian horse, and is unlike in those points to modern European horses, or to the Arabian horse.

It was, until the discoveries of $M$. Piette, held that though the cave-men killed, ate, and made pictures of the

FIG. 7.-Drawing (of the actual size of the original) or an ivory carving (fully rounded) of a female head. The specimen was found in the cavern of Brassempouy, in the Landes. It is of the earliest reindeer period, and the arrangement of the hair or cap is remarkable.

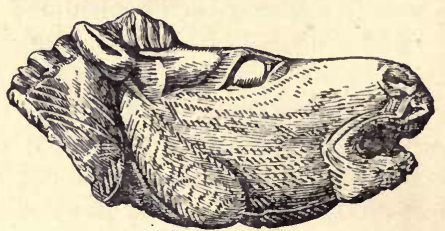

FIG. 8.-Drawing (of the actual size of the original) of a fully rounded carving in reindeer's antler of the head of a neighing horse. The head resembles that of the Mongolian horse. This is one of the most artistic of the cave-men's carvings yet discovered. It is of the Palæolithic age (early reindeer period), probably not less than fifty thousand years old. It was found in the cavern of Mas d'Azil, Ariège, France, and is now in the museum of St. Germain.

horse of those remote days, yet that they did not tame it, put a halter or a bridle on it, and make use of it. Some of the carvings figured by M. Piette leave, however, no room for doubt that the cave-men fitted a bridle to the head and muzzle of the horse. These carvings (Fig. 9) show a twisted thong placed round the nose and passing near the angle of the mouth where it is possible, 
though not certain, that a "bit" was inserted. Connected to this main encircling thong are four twisted cords (on each side of the head), which run horizontally backwards, and the two lower of these are joined by a flat, plate-like piece, which is ornamented. The whole apparatus is further connected to a twisted cord on each side, which runs towards the back of the head, but it is not shown in the carving what becomes of it. Thus it seems clear not only that the cave-men of these remote ages were wonderful artists, but that they mastered and muzzled the horse.

Some of the engravings of horses' heads seem to indicate the existence of a horse alongside the commoner form with a narrower, more tapering face, and may possibly be due to the introduction, even at that remote period, of another race distinct from the Northern or Mongolian wild horse.

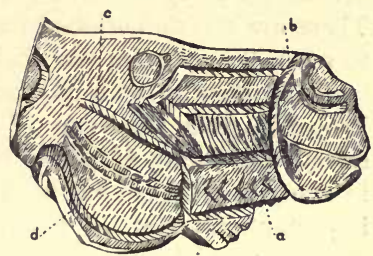

FIG. 9. - Drawing (of the actual size of the original) of a flat carving in shoulderbone, of a horse's head, showing twisted rope-bridle and trappings. $a$ appears to represent a flat ornamented band of wood or skin connecting the muzzling rope $b$ with other pieces $c$ and d. This specimen is from the cave of St. Michel d'Arudy, and is of the reindeer period. This, and others like it, are in the museum of St. Germain.

That this admixture of a distinct and more slender horse with the Northern horse has taken place over and over again in historical times is a matter of knowledge. The question is, when did it first take place, and where did the more slender horse come from? In later days we know this more shapely breed as the Arab and the Barb, and the introduction of its blood at various times into the more Northern stock is well ascertained. The latest great historical case of such admixture is the production 
of the English thoroughbred in the eighteenth century by such sires as the Darley Arabian, the Godolphin Barb, and the Brierley Turk, whose blood is transmitted to modern racehorses through the great historic sires, Herod, Matchem, and Eclipse, the ancestors of practically all modern racehorses.

The horse of more Southern origin thus recognised as distinct from the prehistoric European horse, it is now convenient to speak of as the Southern or Arabian horse. There are certain curious structural features which seem to mark these horses and their offspring, even when their strain is blended with that of the more Northern horse. Probably from the time of the cave-men onward the selective breeding of horses has been carried on, so that in many breeds size has been vastly increased. It is an important fact that the English racehorse has never been selected and bred for "points" (as cattle and sheep are), but always by performance on the racecourse. Thus it becomes an extremely interesting matter to see what are the changes which the breeder of thoroughbred stock has unconsciously produced-what are the differences between the racehorse of to-day and that of 50 , 100, and I 50 years ago. This was pointed out to me by the late Duke of Devonshire as a reason for supporting my proposal to secure and place in the Natural History Museum the skulls, limb-bones, hoofs, and other indestructible parts of great racehorses (and of other breeds), and also for having very accurately measured reduced models made of such horses, in order that we may after some years compare the proportions and structure at present arrived at with the later developments which the continual selection of winner's blood in breeding must unconsciously produce. Such a collection was started by me in the museum, but it needs the assistance of owners of horses-both as to placing record 
specimens in the museum and in paying for the preparation of accurately reduced models by competent artists. It already comprises the skulls of Stockwell, Bend Or, and Ormonde, and several carefully made reduced models of celebrated horses. There is no doubt that the English racehorse has increased in size. $\mathrm{He}$ is a bigger animal to-day than he was 200 years ago, and the opinion of the best authorities is that he has increased on the average an inch in height at the withers in every twenty-five years. The racehorse has a much longer thigh-bone and upper-arm bone (in proportion to the rest of the leg) than has the cart-horse, and it is probable that this length has been continually increased by the selection of winners for breeding.

There are other points of scientific interest as to modern horses and their forefathers which are illustrated by valuable specimens and preparations placed by me in the Natural History Museum.

All those hairy warm-blooded quadrupeds which suckle their young, and are hence called mammals, are the descendants of small five-toed ancestors about the size of a spaniel. This is equally true of the elephant, the gorilla, the horse, and the ox. In the sands and clays deposited since the time of the chalk-sea, the remains (bones and teeth) of the ancestors of living mammals are found in great abundance. These sands and clays are called "the Tertiaries," and are divided into lower, middle, and upper-whilst we recognise as "Post-Tertiaries" (or Quaternary) the later formed gravel and cave deposits in which the remains and weapons of the cave-men have been found. The Tertiaries consist of a series of deposits amounting to about 3000 feet in thickness, and they have taken several million years in depositing - no one can say how many. 
In the upper Tertiary we find the remains of a kind of horse (the Hipparion), with well-developed "petti-toes" (like those of a pig) on each side of the big central toe (Fig. IO). In the middle Tertiary we

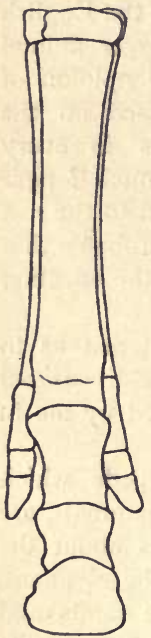

\section{HIPPARION} find smaller ancestral horses, with three toes of nearly equal size, and in the lower Tertiary

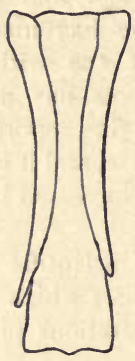
a horse-ancestor as small as a fox-hound (the Hyracotherium), with four toes on its front foot and three on its hind foot. Coming very close to this in general character is another small extinct animal of the same age, with five toes on each foot. As the toes have dwindled in number and size, leaving at last only the big central toe (as we pass upward from the small ancestors to the big modern horse), so the cheek-teeth, too, have changed. At first they had shallow crowns and divided

HORSE FIG. 10.-To the left, the fore-foot of the horse-ancestor, Hipparion, showing three toes: to the right, the back view of a long bone of a modern horse's foot, with rudiments of outer toes, called splintbones. took to eating coarse tooth-
wearing grass, his teeth became deeper, and continued to grow for a long time, whilst the crown was rubbed down by the hard food, and a curiously compiex pattern was brought into view by the exposure of the irregular bosses of the crown in cross section. And, meanwhile, the size 
and proportions of the horse-ancestors changed until, after being pig-like, then tapir-like, they acquired the perfect form and size for fleet and prolonged movement over firm, grass-grown plains. Horses and other large animals have to run, not only to escape pursuit by carnivorous enemies, but in order to travel, before they die from thirst, from a region suddenly dried up by drought to a region where water can be had. Many thousands of wild animals perish every year from local droughts in Africa. No small animals can exist in regions liable to be affected by sudden drought.

Three-toed horses, like the upper Tertiary Hipparion, are occasionally born as "monstrosities" from ordinary horses at the present day. All horses have the remnant of a toe on each side of the big central toe-in the form of splint-bones-concealed beneath the skin. In some breeds, for instance, in the "Shire" horses, which have enormous hairy feet in proportion to their huge strength and weight, these splint-bones tend to develop three little toe-joints, which are immovable, but obviously are "petti-toes." It is related by Suetonius that Julius Cæsar used to ride a favourite horse which. had several toes on each foot with claws like a lion. This was one of the "monstrosities" alluded to above, a throw-back to the ancestral many-toed condition. Specimens illustrating these, and all else which I am here relating concerning horses, and much more which I have not space to tell, may be seen in the North Hall of the Natural History Museum.

The three-toed ancestral horse, Hipparion, attained a fair size (that of a big donkey), and was shaped like the recent fleet one-toed horses. In the skull in front of the orbit, the Hipparion has a strongly marked depression in the bone, as long and broad as a hen's egg, and in shape 
like one-half of an egg cut through longwise (see Fig. I I $p f)$. These pre-orbital cavities are known in deer, sheep, and antelopes; they lodge a gland resembling the teargland, which has, itself, a separate existence. Similar "glands" are found in the feet and ankle-joints of sheep and deer. The fluid which they secrete probably has an odour (not readily noticed by man) which helps to keep the herd together, or, on certain tracks when the fluid is smeared
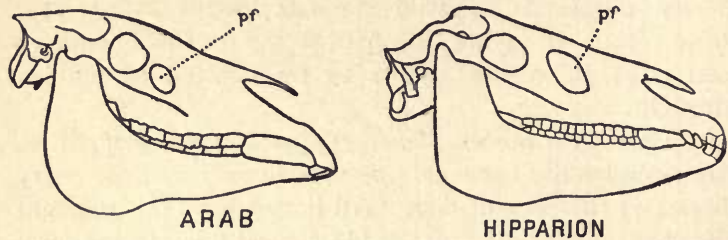

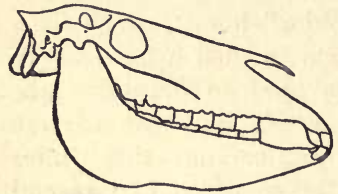

PREVALSKY'S HORSE

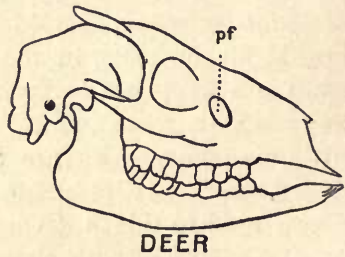

FIG. II. -Skulls of horses and of deer to show the pre-orbital pit or cups $p f$, and its absence in the Mongolian (Prevalsky's) horse.

on to herbage. It is a remarkable fact that the skulls of the wild Mongolian horse and of the fossil horse of the cave-men, as also those of the commoner European breeds, have no trace of this pre-orbital cup or of the gland which Hipparion, their three-toed ancestor, possessed. Nor, indeed, have the asses and zebras. But the Southern horse, the Arab, and all the breeds into which his blood has prominently entered-as, for instance, the English racer (so-called "thoroughbred") and the 


\section{MODERN HORSES AND THEIR ANCESTORS 87}

"Shire" horse (which is derived from the old English warhorse, in the making of which certainly four hundred years ago Arab blood and heavy Northern stock were mingled), do show, as a rule, a well-marked if shallow, cup-like depression in front of the orbit! In fact, as Mr. Lydekker has pointed out, the presence of this "preorbital cup" is evidence of the descent of its possessor from Arab ancestry. Many specimens of horses' skulls showing this "cup" are exhibited in the Natural History Museum. We have not been able to find any trace of a gland like the "larmier" of deer and the "crumen " of antelopes on examining the soft tissues which overlie this cavity in horses of Arab descent, but it is not improbable that occasional instances of such survival will some day come to light. A very interesting fact in connection with this concavity and its indication of a distinction between the Northern (Mongolian) and the Southern (Arabian) horse is that in India a fossil horse of very late Tertiary date has been found, a true onetoed horse, not a Hipparion, which has the pre-orbital cup well marked, and is possibly the ancestor of the Arab.

There is no very great difference between the wild horse and wild asses and zebras. They are distinct "species," but will breed together and produce "mules," which in rare cases appear to be themselves fertile, although this is doubtful. The inner causes of the infertility of mules are not really known or understood. Nor, in fact, do we know really and experimentally what are the causes of fecundity and of infecundity in normally paired animals, including mankind. It is of the utmost importance to modern Statecraft that this subject should be studied, and there is a great field for experimental inquiry.

A clear mark of difference between the horse and the other species of the genus Equus (namely, the Asiatic 
and African asses and the zebras) is found in the curious wart-like knobs $^{1}$ on the legs, which are called "chestnuts." These warty knobs appear to be the remains in a "dried up" condition of glands, such as are found in the legs of deer in a similar position, and secrete a glairy fluid. In new-born colts they sometimes exude a fluid, and also more rarely in adult horses. The fluid attracts other horses (probably by its smell), and also causes dogs to keep quiet. The horse has one of these wart-like

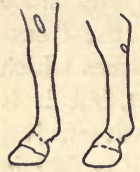

HORSE

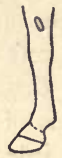

A S S

Fig. 12.-Fore and hind legs of horse and ass, to show the " chestnuts," and the absence of that structure from the hindleg of the ass.

"chestnuts" above the wrist joint (so-called knee) on the inner side of the fore-leg. And so have all the asses and zebras. But the horse (Fig. I2) has also a similar "chestnut" on the inner side of each of its hind-legs, below the heelbone, or "hock." This hindleg chestnut is absent in all asses and zebras. This difference between the horse and ass can be tested by my readers on any roadside by their own observation. The hind-leg chestnut is also absent in certain breeds of ponies from Iceland and the Hebrides. Its presence and absence are interesting in connection with the disappearance of the face-gland or pre-orbital gland in all recent horses, asses, and zebras.

The "chestnuts" of the horse have sometimes been compared erroneously to the "pads" on the feet of other animals, and supposed to be survivals of a"pad " in

1 The names "malander" and "salander" have been recently applied by zoological writers, apparently by misconception, to these "callosities" or "chestnuts." Those names are used by veterinary surgeons to describe a diseased condition of this part of the horse's leg (Italian "mal andare"), and do not apply to the "chestnut" itself, which is sometimes called "castor." 


\section{MODERN HORSES AND THEIR ANCESTORS 89}

each foot corresponding to the inner of the three toes of the Hipparion. The real representative, in the horse, of the chief pad of the foot of animals which do not (as the horse does) walk on the very tip of the toe, is a little knob called the "ergot." The diagram, Fig. I 3, shows how this ergot corresponds to the chief pad of the three-toed tapir's foot, and so to that of the dog also.

The absence of living horses, or of any kind of ass or zebra, from the American Continent, when first colonised by Europeans in the sixteenth century, is a very singular fact. For we find a great number and variety of fossil remains of extinct horses in both North and South America. It seems possible that some epidemic disease swept them from the whole Continent not very many centuries before
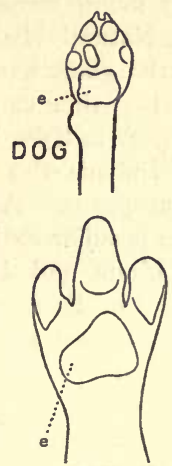

TAPIR

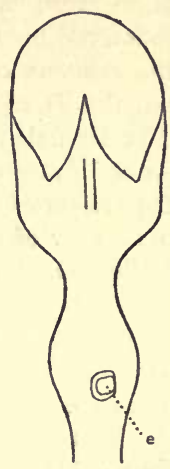

HORSE

Fig. 13.-Diagram of the under surface of the foot in the dog, tapir, and horse, to show that the horny knob of the horse's foot, called the "ergot," corresponds to the central "pad" of the other two.

Europeans arrived - for

there is evidence in South America of the co-existence there of peculiar kinds of horse with the "Indian" natives. It is even alleged that Cabot, in 1530 , saw horses in Argentina, which were the last survivors of the native South American species. And it is also said that the Araucanian Indians of Patagonia have a peculiar breed of ponies, which may be derived in part from a native South American stock. I have never been able to procure a skull of this breed, or any detailed description 
of it. What is quite certain is that in the great cave of Ultima Speranza, in Patagonia - from which the hairy skin, dried flesh and blood, and unaltered dung as well as the bones, of the giant sloth Mylodon were obtained-a great number of the horny hoofs, and the teeth of a peculiar horse were also found some eight years ago, and are preserved in the Natural History Museum, together with the remains of the giant sloth. The condition of these remains is such that they cannot be many centuries old. The animals appear to have been contemporaneous with an early race of Indians who made use of the cave before the arrival of Europeans. A skull of one and a skeleton of another of the peculiar extinct South American horses (called Onohippidium and Hippidium), which survived until a late period in Patagonia and may possibly have been seen by Cabot, are shown in the Natural History Museum. Their bones are found in the superficial gravel and sand of the pampas.

To revert for a moment to the history of the English thoroughbred. It appears that in England in the middle of the eighteenth century a happy new infusion of the Arab race with that of existing stock (which already contained some Arab blood mixed with that of the Northern race) produced once and for all a very perfect and successful breed. That breed did not derive speed from the Arab, but "stamina,"- probably a powerful heart. It did not derive its size from the Arab, but the cross proved to be a large horse. It has never been improved since by any further admixture of Arab or Southern blood. Hence the (at first sight) misleading name "thoroughbred." This name is not intended to imply that the breed is not originally a "blend," but that those horses so called are pure-bred from the happy and wonderful mixture which a hundred and fifty years ago was embodied in the great sires Matchem, Herod, and Eclipse. 


\section{$\mathrm{XI}$}

\section{A RIVAL OF THE FABLED UPAS TREE}

\} { } ^ { \mathrm { E } } \text { are so accustomed nowadays to danger to life } and health from minute, invisible germs, and to exerting all our skill in order to destroy them, that the knowledge of the existence of large and beautiful trees in our midst which can, and do, cause terrible disease and suffering by their mere presence, comes as a shock, and produces a peculiar sense of insecurity greater even than that excited by unseen micro-organisms. For the trees of which I am about to speak are cultivated in our gardens, trained up against the walls of our houses with loving care, and admired for the beautiful autumn tints of their leaves. Yet it is now certain that they are the cause in many persons of most terrible suffering and illness. I am glad to be able to warn my readers in regard to these plants, and I shall be very much interested to hear whether the information which I am about to give proves to be of value in any particular case.

A married couple, friends of my own, went to live, about fourteen years ago, in a newly built, detached house, standing in its own garden, in the neighbourhood of an English city. After they had been there two years the lady developed a very painful eruption or eczema on the face, which, in the course of a few weeks, caused the eyes, nose, and lips to swell to an extraordinary 
degree, accompanied by the formation of blisters and breaking of the skin. The affection spread to the body, and caused constant pain and corresponding prostration. Her medical attendants were unable either to cure or to account for her condition. After some months she left home, and entirely recovered. But every year the same distressing and disfiguring illness attacked her (commencing in the month of June), and disappeared as soon as she left her house, only to return when she came back to it. The doctors spoke of her affliction as a mysterious form of erysipelas, and even suggested blood-poisoning as the cause. For long periods she was so ill and in so much pain that she was unable to see her friends, and her life was at times in danger.

Two years ago a weekly newspaper published an account, written by a correspondent, of an illness from which he had suffered-exactly agreeing with that which had for so many years tortured my friend's wife. This writer stated that he had ascertained that the disease was due to the action of a poison given off by a creeper which grew on the walls of his house. He had supposed this plant to be a Virginian creeper; but he had discovered that it was in reality the Californian poison-vine called by botanists Rhus toxicodendron. The terribly poisonous nature of this plant is well-known to the people of the United States. It is one of the sumach trees, of which other poisonous kinds are known, whilst more than one species is used (especially in Japan) for preparing a resinous varnish which is used in the manufacture of "lacquered" articles. The writer in the weekly paper stated that he had cut down and burnt the poisonvine which grew on the walls of his house, and that his sufferings had ceased. My friend happened to read this account, and immediately examined his own house. $\mathrm{He}$ found a creeper resembling a Virginian creeper, but 
having three leaflets or divisions of the leaf instead of five, growing around his drawing-room window, and actually spreading its branches and leaves over the window of his wife's bedroom. He sent specimens of the creeper to Kew, where it was at once identified as the Rhus toxicodendron or American poison-vine or poison-ivy. He caused the plant to be removed and burnt, and, except for a slight attack in July, due no doubt to fragments of the leaves still carried about in the form of dust, his wife has recovered her health.

I have looked into this matter with care, and I find that (presumably in ignorance) nurserymen in England have sold specimens of the poison-vine for planting as creepers, under the name Ampelopsis Hoggii. The smaller-leaved Virginian creeper, with self-attaching tendrils, is known as Ampelopsis Veitchii, and is, like the larger Virginian creeper (A. quinquefoliata), quite harmless. The poison-vine is not an Ampelopsis at all, not even one of the Vitaceæ or vine family, as that genus is. It is a Sumach or Rhus, and belongs to a distinct family, the Terebinthaceæ. It has a three-split leaf, not five leaflets, as has the large Virginian creeper, nor a small three-pointed leaf, as has the Ampelopsis Veitchii. The Veitchii frequently has the leaf also split into three leaflets, but the stalk of the middle leaflet is not relatively so long as it is in the poison-vine. The differences and resemblances in the leaves of these plants are shown in the accompanying illustration (Fig. 14), which has been prepared from actual specimens for this book.

The people of the United States are on their guard against this plant, knowing its terrible properties. Sir William Thiselton Dyer, formerly director of Kew Gardens, tells me that specimens of the "American poison-vine" are grown in the garden at Kew, and that he has been present when American visitors (ladies) literally screamed with horror on seeing it, and ran from it as from a mad 
dog. Several cases are on record of the mysterious poisoning produced by this plant in England; but it is strangely unfamiliar to medical practitioners - indeed, practically unknown to them, although I have ascertained that many English people, especially ladies, have been victims for some years to its unsuspected influence.

At the University of Harvard, in Cambridge, Massachusetts, they have made quite recently a thorough examination of the poison-vine in the laboratory, with the following results: The poison is an oil-a fixed oil, not a volatile one, as we might have imagined from its mysterious action at a distance. The oil exists in all parts of the plant, even in the fine hairs and cuticle of the leaf. It can be extracted by means of ether, and is one of the most virulent irritants known, having a very curious penetrating and persistent action, and producing violent pain and destruction of tissue when placed on the skin in quantity so minute (one-thousandth of a milligram in two drops of olive oil) as to be beyond the terms of everyday language. It seems to be usually brought to the eyes, nose, lips, and skin of the face and body by the fingers which have touched a leaf or fragments of a leaf in powder. The dead leaf in winter still retains the oil, and minute dust-like particles can carry it. The treatment for it is washing with soap, oil, and ether at an early stage of the attack-especial care being taken to free the fingers from any minute traces of the oil adhering to them.

The poison of the poison-vine only acts upon a limited number of individuals, many people being perfectly immune. At the same time, the effect upon susceptible people appears to be enhanced with every fresh attack; even after the total removal of the poison-vine and its dust from proximity to a susceptible person, he or she is apt for some time-owing to the retention of some trace 


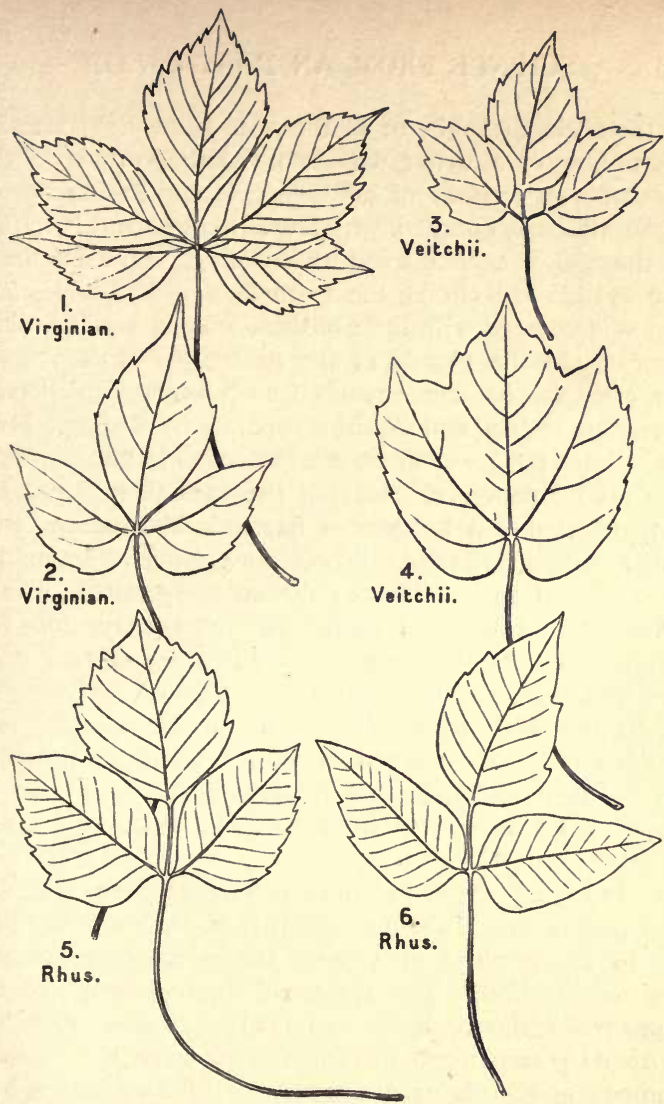

FIG. 14.-Drawings, about half the natural size, of the leaves of the common quinquefoliate Virginian creeper ( 1 and 2), of the adherent "Ampelopsis Veitchii" (3 and 4), and of the poison-vine, Rhus toxicodendron (5 and 6). From specimens in the Botanical Department of the Natural History Museum. Note especially the greater length of the stalk of the central leaflet in the poison-vine. Note also that the common Virginian creeper has sometimes only three leaflets (2) instead of five, and that "Veitchii" has either three leaflets, as in 3 , or has the leaflets united into one threepointed leaf, as in 4 . 
of the oil in the skin or clothes-to have slight attacks. According to a writer who two years ago gave in the Spectator an account of his own case, the first symptom of an attack is almost invariably a redness and irritation of the eyelids, accompanied by shivering. In a few hours the eyelids are closed, the features unrecognisable, and the skin covered with little blisters. Then the lips swell enormously, the glands of the neck also. In four days the arms and hands are reached, each finger appearing as if terribly scalded and requiring separate bandaging. Then sometimes the lower limbs are involved. After ten days the attack passes off, leaving the patient in a pitiable state of weakness to grow a new skin and recover from other painful results of the poisoning. But no immunity is conferred by an attack; the unhappy victim (who is ignorant of the cause of his sufferings) may, and frequently does, get a new dose of the poison as soon as he has recovered, and the whole course of the illness has again to be passed through. If this account should fall into the hands of any one who is being unwittingly poisoned by the American poison-vine, and may therefore be saved by what I have written from further suffering, I shall be greatly pleased.

There are very few plants which have a power of diffusing poison around them; usually it is necessary to touch or to eat portions of a plant before it can exert any poisonous effect. The eighteenth-century story of the upas-tree of Java, which was fabled to fill a whole valley with its poisonous emanation, and to cause the death of animals and birds at a distance of fifteen miles, is now known to be a romantic invention. The tree in question is merely one having a poisonous juice which was extracted and used by the wilder races of Java as an arrow poison. It is stated that one of the stinging-nettles of tropical India has such virulent poison and such an 
abundance of it in the hairs on its surface, that explorers have been injured by merely approaching it, the detached hairs probably floating in the air and getting into the eyes, nose, and throat of any one coming near it. The poison of the poisonous stings of both plants and of animals has been to some extent examined of late years. It is a curious fact that there are proportionately few plants which sting as compared with the number and variety of animals which do so. On the other hand, there are an enormous number of plants which are poisonous to man when eaten by him, but there are very few animals which are so.

It will be of interest to my readers to know that I received, in consequence of the publication of the foregoing account of the "Poison-vine" or "Poison-ivy," more than fifty letters and boxes containing leaves. At Kew Gardens nearly a hundred applications were made with a request for the identification of leaves. The proportion of cases in which leaves of true poison-ivy (Rhus toxicodendron) were sent to me seems to be the same as that which they observed at Kew-only two samples of the leaves sent to me were those of the true poison-ivy. Hence we may conclude that the plant has not been very largely introduced in this country, and probably there are not many hundred cases existing in England of the painful malady which it can, in certain people, produce. I have, however, received information of several instances of this poisoning from different parts of the country, which are either now under treatment or have been cured, and in some cases the poison-ivy has been discovered as the cause, owing to the description which I published. It is certainly true that the illness caused by this plant only attacks a small proportion of those who handle it, and it is possible that the plant is more virulent at some seasons and in some 
soils than in others. In the United States, even in the neighbourhood of New York, it is a real danger, and is recognised as such, but as appears from a letter which I quote below, the reason of the dread which the "poison-ivy" excites in the States depends on the fact that it is not there a mere garden plant, but grows wild in great abundance in the woodlands frequented by holiday-makers and lovers of natural forest and lakeside wilderness. The poisonous nature of the allied species of Rhus used for the manufacture of "lacquer" or varnish is recognised by the Japanese and others who prepare this product and have to handle the plant-they wear gloves to protect the hands.

As showing what kind of trouble the "poison-ivy" and "poison-oak" (another kind of Rhus or Sumach) give in the United States, I will quote a letter I have received from an American lady well known in London society. She says: "I have known, suffered, and struggled against the poison-ivy in America from my earliest years, when my poor mother lay for days with blinded and swollen eyes, having gathered it inadvertently. The 'poison-ivy,' as we call it, is a curse to country life, outside the purely artificial and cultivated gardens, and even there it creeps in insidiously." She describes a beautiful farm property on Lake Champlain, on the Canadian border, where she and her family would spend many weeks in summer in order to enjoy the delights of complete seclusion in wild, unspoilt country: "The one and only drawback to the place was," she writes, "the inexhaustible quantity of poison-ivy. Our first duty had been to teach my two daughters and their governess how to distinguish and avoid contact with it. The one and only rule was that the poison-ivy has the clusters of three leaflets (the middle leaflet with a longer stalk, E.R.L.), whereas the woodbine (not the English wood- 
bine, which is a convolvulus, E.R.L.), or, as you call it, 'Virginian creeper,' has five leaflets in a cluster. Every path which we used frequently and necessarily, such as the path to the boat-house, and to the cove where the bathing-house stood, we kept cleared of the Rhus for a sufficient width, but in the woods eternal vigilance was the price of safety. To uproot and burn is the only way to destroy it, but, of course, that involves danger to the one who does the work, because contact with the spade used, and with the garments which touched the ivy, might communicate the poison. The farmer and the countryfolk about declared that the fumes from the burning plant could and did poison those who breathed them. We used to turn a flock of sheep into the most used parts. They prefer the poison-ivy to grass, and greedily eat down every leaf within reach in hedge or path. But that, of course, was a mere temporary safety, as the plant is most tenacious of life. I personally had a most grievous, experience one summer. I can only suppose that my dress, though very short for wood and hill walking, brushed over the poisonous plant, and then, when I undressed, came into contact with my skin. Both legs became covered with the eruption, eventually developing pustules, and the agony of itching, burning, and smarting was indescribable. The first remedy applied is usually a frequent use of baths of some alkali, generally common soda. With me it was altogether inadequate, and the doctor carefully covered the affected parts with a thick layer of bismuth, and bandaged them, so as to exclude all air. But it took weeks to cure me. A very serious result in many cases is that there is a recurrence of the itching for several years." 


\section{XII}

\section{POISONS AND STINGS OF PLANTS AND ANIMALS}

TO give an account of poisonous plants would require a whole volume. Among plants of every degree and kind are many which produce special chemical substances which are more or less poisonous, and yet often of the greatest value to man when used in appropriate doses, though injurious and even deadly if swallowed in large quantity. Plants are laboratories which build up in a thousand varieties wonderful chemical bodies, some crystalline, some oils, some volatile (as perfumes and aromatic substances), some brilliantly coloured (used as dyes), some pungent, some antiseptic, some of the greatest value as food, and some even digestive, similar to or identical with those formed in the stomach of an animal.

Man, the chemist, every year is learning how to produce in his own laboratories, from coal and wood refuse, many of these bodies, so as to become to an everincreasing extent independent of the somewhat capricious and costly services of the chemists supplied by naturethe plants. In a recent exhibition there was a case showing on one side the various essential oils used to make up a flask of eau-de-Cologne, and specimens of the plants, flowers, leaves, and fruits from which they are 
distilled. On the other side of the case was a series of bottles showing the steps in the process by which the modern chemist manufactures from coal-tar and cokerbutter the same bodies which give value to the vegetable extracts, and there was finally a bottle of what is called "synthetic eau-de-Cologne" - that is, eau-de-Cologne put together from the products manufactured by the human, instead of the vegetable, chemist.

Whilst man has learnt to avoid swallowing poisonous plants, although occasionally blundering over prettylooking berries and deceptive mushrooms, he has had little to fear in that way from animals. To a small degree this is due to the fact that only parts of animals are eaten by man, and those very generally are cooked before being eaten, the heating often sufficing to destroy substances present in flesh, fish, and fowl which would be poisonous if taken raw. But, as a matter of fact, animals do not generally protect themselves from being eaten, as plants largely do, by developing nasty or poisonous substances in their flesh, though some do. They fight rather by claws, teeth, and poison glands therewith connected, or else escape by extra quick locomotion, a method not possible to plants. Many insects (butterflies, beetles, and bugs), however, produce nasty aromatic substances which cause animals like birds and lizards to reject them as food. The toad and the salamander both procuce a very deadly poison in their damp, soft skins, which causes any animal to drop them form its mouth, and to regret "bitterly" the attempt to swallow them. The frog has no such poison in its skin, but can jump out of harm's way. The strong yellow and black marking of the European salamander is what is called a "warning" coloration, just as is the yellow and black outfit of the poisonous wasp. Animals learn to leave the yellow and black livery untouched, and 
the creatures so marked escape the injury which would be caused them by tentative bites.

There is a curious variation as to susceptibility on the part of man to poison in the flesh of fishes and shell-fishes when taken by him as food. The word "idiosyncrasy" is applied to such individual susceptibility, and is, of course, applicable to the susceptibility shown by some persons to the poison of the American poison-vine, described in the last article, and of others to acute inflammation from the dust of hayfields. Some persons cannot eat lobster, crab, or oysters or mussels without being poisoned in a varying degree by certain substances present in those "shell-fish" even when cooked. Often a "rash" is caused on the skin, and colic. Others, again, cannot eat any fish of any kind without being poisoned in a similar way, or possibly are only liable to be poisoned by grey mullet or by mackerel. The most curious cases of this individual variability are found in the rash and fever caused by the vegetable drug quinine in rare instances, and the violent excitement produced in some persons by the usually soporific laudanum. All such cases have very great interest as showing us what a small difference separates an agreeable flavour or a valuable medicine from a rank poison, and how readily the chemical susceptibility of a complex organism like man may vary between toleration and deathly response, without any concomitant indication of such difference being apparent (in our present state of knowledge), in two individuals, to one of whom that is poison which to the other is meat. They also furnish a parallel to that marvellous conversion of "toxin " into "anti-toxin," in consequence of which the blood of an animal injected with small, increasing doses of deadly snake poison or diphtheria poison becomes an antidote to the same poison taken into the blood of an unprepared animal. 
There is, over and above these special cases of fish foods which are tolerated by some and are poison to others, a whole series of fishes which cannot be eaten by any one without serious poisoning being the result, even when the fish are carefully cooked. Happily, these fishes are rarely, if ever, caught on our own coasts. They produce, when even small bits are eaten, violent irritation of the intestine, and death, the symptoms resembling in many respects those of cholera. The curious bright-coloured, beaked fish of tropical seas and coral reefs, with two or four large front teeth and spherical spine-covered bodies, and the trigger fish of the same regions, are the chief of these poisonous fish. But there is a true anchovy on the coast of Japan, and a small herring in the West Indies, and a goby on the Indian coast (Pondicherry), all of which are deadly poison even when cooked; and there are many others. So one has to be careful about fish-eating in the remoter parts of the world. The poisons of these fish with poisonous flesh have not been carefully studied, but they seem to resemble chemically the poisons produced by certain putrefactive microbes.

Let us now revert to the more special subject of poisonous stings. Every one knows that although it is unpleasant to be pricked by the little spines on the leaf of a thistle, it is not the same unpleasantness as being "stung" by a nettle. There is no poison in the thistle. The hairs which beset the leaves of the common nettle are firm, but brittle and hollow; they break off in the skin, and a poison exudes from their interior. Under the microscope-and it is quite easy to examine it with a high power-the hollow nettle hair is seen to be partly occupied by living protoplasm-a transparent, viscid substance which shows an active streaming movement, and has embedded in it a dense kernel or nucleus (see 
Fig. I 5 bis). It is, in fact, a living "cell," or life unit The space in the cell not occupied by protoplasm is filled with clear liquid, which contains the poison. This has been examined chemically by using a large quantity of nettle hairs, and is found to contain formic acid-the same irritating acid which is secreted by ants when they sting, whence its name. But later observations show that the juice of the nettle hair contains also a special poison in minute quantities, an albuminous substance, which resembles that contained in the poison-sacs at the base of the teeth of snakes.

In tropical regions there are nettles far more powerful than that of our own country. The one called Urtica stimulans, which is found in Java, and that called Laportea crenulata, found in Hindostan, when bruised emit an effluvium which poisonously affects the eyes and mouth, and if handled produce convulsions and serious swelling and pain in the arms, which may last for three or four weeks, and in some cases cause death. They are not unknown in the hothouses of our botanical gardens, and young gardeners are sometimes badly stung by them. There are other plants provided with poisonous stinging hairs besides the true nettles or Urticacea, though they are not numerous. The American plants called Loasa sting badly, so do some of the Spurges (Euphorbiacee), and some Hydrophyllece.

The Chinese primrose (Primula obconica), lately introduced into greenhouses, has been found to be almost as injurious as the poison-vine. Its effects, of course, are limited to a much smaller group of sufferers. And it is worth while, in connection with poisoning by primula and the poisoning by Rhus toxicodendron of only certain individuals predisposed to its influence, to point out that the malady known as hay fever seems to be similar in its character to these vegetable poisonings. It is, of course, 
well known that only certain individuals are liable to the more violent and serious form of hay fever. It is not at all improbable that this irritation of the air passages, often attributed to the mechanical action of the pollen of grass and other plants-really is due to minute quantities of a poison like that of the poison-vine, present in the pollen of some hay plant yet to be suspected, tried, and convicted. ${ }^{1}$

With regard to a poisonous action at a distance being possibly exerted by plants, we must not overlook the effects of some perfumes discharged into the air by flowers. Primarily such perfumes appear to serve the flowers by attracting to them special insects, by whose movements and search for honey in the flowers the pollen of one is conveyed to another and fertilisation effected. Human beings are sometimes injuriously affected by the heavy perfume given out by lilies and other flowers, headache and even fainting being the result. No instance is known of serious injury or death resulting in the regions where they grow from the overpowering perfume of such flowers. But that admirable story-teller, Mr. H. G. Wells, has made a legitimate use of scientific possibilities in imagining the existence of a rare tropical orchid which attracts large animals to it by its wonderful odour. The effects of the perfume are narcotising; the animal, having sniffed at the orchid, drops insensible at the foot of the tree trunk on which the orchid grows. Then the orchid rapidly, with animal-like celerity, sends forth those smooth green fingers or "suckers," which you may see clinging to the pots and shelves on which an orchid is growing

${ }^{1}$ Since the above was written, I have seen the account by an American physician -in a recently issued volume of Osler's Treatise on Medicine- of his recent discovery of the grass which produces in its pollen the poison of hay fever, and of the preparation by him of an anti-toxin which appears to give relief to those who suffer from hay fever. 
As they slowly creep, in their growth, over the poisoned animal, they absorb its life's blood painlessly and without disturbing the death-slumber of the victim. Mr. Wells supposes a retired civil-servant, with feeble health and a passion for orchids, to have purchased an unknown specimen, which, after some months of nursing, is about to blossom in the little hothouse of his suburban home. He goes quietly and alone one afternoon, when his housekeeper is preparing his tea, to enjoy the first sight and smell of the unknown flower, and is found, some three hours later, lying insensible before the orchid, which is giving out an intoxicating odour, and is looking very vigorous and wicked. A blood-red tint pervades its leaves and stalks, and it has already pushed some of its finger-like shoots round the orchid-lover's neck and beneath his shirt front. When they are pulled away a few drops of blood flow from the skin where the absorbent shoots had applied themselves. The victim recovers.

When we take a survey of the "stings" and poisonfangs and spurs of animals, we find a much greater abundance and variety of these weapons than in plants. They serve animals not only as a means of defence, but very often for the purpose of attacking and paralysing their prey. We have to distinguish broadly between (a) gut-poisons and (b) wound-poisons. The slimy surface of the skin and the juices of animals are often poisonous if introduced into wounds, but harmless if swallowed, though in the toad and salamander the skin contains a poison which acts on the mouth and stomach. Thus the blood of the eel is poisonous to higher animals if injected beneath the skin, though not poisonous when swallowed. Pasteur found that the saliva of a healthy human baby a few weeks old produced convulsions when injected beneath the skin of a rabbit. The fluid of the mouth in fishes (Murcena), in some lizards (Heloderma), 
and some warm-blooded quadrupeds, like the skunk, is often poisonous, and is introduced into the wound inflicted by a bite. The elaboration of a sac of the mouthsurface secreting a special quantity of poison to be injected by aid of a grooved tooth, such as we find in poisonous snakes, is only a mechanical improvement of this more general condition. The same general poisonous quality is found in the slime of the skins of fishes which have spines by means of which poisonous wounds are inflicted (sting-rays). And here, too, an elaboration is effected in some fishes in which a sac is provided for the accumulation of the poison, and a specially grooved spine, to convey the poison into the wound inflicted by it. A common fish on our coasts, the weever (probably the same word as viper), is provided with grooved, stinging spines, but no special poison-sac. Some of the poison-carrying spines support the front portion of the dorsal fin, which is of a deep black colour, a striking instance of the warning coloration which poisonous animals often possess.

The poison introduced into wounds by the spines or fangs of animals is essentially similar to that of nettle hairs; it has the effect of paralysing and of producing convulsions. It is a remarkable fact that formic acid often in insects accompanies the paralysing poisonas it does in the nettle-and produces intense pain and irritation, which the more dangerous nerve-poison does not. Immunity to a given wound-poison may be produced by the injection of doses of it, at first excessively minute, but gradually increased in quantity. A remedial "anti-toxin" is thus prepared from the blood of immunised animals, which is used as a cure or as a protection by injecting it into other animals exposed to bites or wounds conveying the particular poison by the use of which the anti-toxin was produced. Bee-keepers who have 
often been stung become in many cases immune, and do not suffer from bee-sting. Men who in France pursue a business as viper-catchers, are said to become immune to viper's poison in the same way Snakes and scorpions are but little, if at all, affected by their own poison when it is injected into them. This appears to be due to the fact that the poison-producing animal is always absorbing into its blood very minute doses of the poison which it has elaborated and stored up in its poison-sac connected with the poison-gland. This small quantity of poison continually absorbed is continually converted into an anti-toxin-just as happens when a horse is treated with doses of snake-poison to prepare the remedial antitoxin for use in cases of snake-bite, or with diphtheriapoison in order to prepare the diphtheria anti-toxin now so largely used. The anti-toxin is a substance very closely similar in chemical constitution to the toxin by the conversion of which it is formed in the blood. Its action on the toxin (or essential poisonous substance of the venom) appears to be a very delicate and slight chemical disturbance of the constitution of that chemical body. Yet it is enough to cause the injurious quality of the toxin to be suddenly and completely abrogated, although from the point of view of chemical composition it is only, as it were, shaken or given a twist! Such great practical differences in the action on living creatures of chemical bodies having themselves so subtle a difference of chemical structure as to almost defy our powers of detection, are now well known.

I made some experiments a few years ago on the poison of scorpions, which were published by the Linnæan Society. I obtained live scorpions-a beautiful citroncoloured kind, of large size-from Biskra, in Algeria (Fig. I 5). The poison-gland and sac are double, and contained in the last joint of the tail, which is swollen, 
and ends in a splendid curved spine or sting. The scorpion carries its tail raised in a graceful curve over its back, and strikes with the sting by a powerful forward stroke. One can seize the tail by the last joint but one, and thus safely hold the animal, and see the poison exude in drops from the perforated sting. I found that if I pressed the sting thus held into the scorpion's own body, or into that of another scorpion, no harm resulted

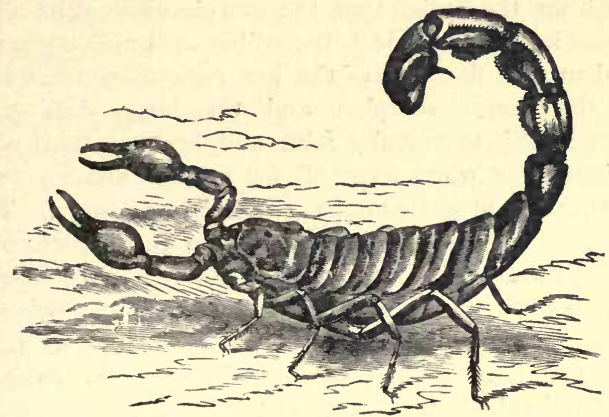

FIG. I5.-Drawing from life of the desert scorpion (Buthus australis, Lin.), from Biskra, N. Africa, of the natural size. (From Lankester, Journ. Linn. Soc. Zool., vol. xvi. 1881.)

to the wounded animal, although plenty of the poison entered the little wound made by the sting. A large cockroach or a mouse similarly wounded by the sting was paralysed, and died in a few minutes. It is a custom in countries where scorpions abound, and are troublesome, and even dangerous to human life, for the natives to make a circle of red-hot charcoal, and to place a large scorpion in the centre of the enclosed area. The scorpion, it is stated, runs round inside the circle, and, finding that escape is impossible, deliberately drives its sting into its back, and so commits suicide. My experi- 
ments showed that the scorpion could not kill itself in this way, as its poison does not act on itself. Moreover, it has been shown by Professor Bourne, of Madras, that although scorpions constantly fight with one another, they never attempt to use their stings in these battles, but only their powerful, lobster-like claws. The stings would be useless, and are reserved for their attacks on animals susceptible to the poison. I also found the ground for the belief that the scorpion kills itself when enclosed in a fiery circle. Incredible as it may appear in regard to such denizens of the hot regions of the earth, both the desert scorpion and the large dark-green Indian scorpions actually faint and become motionless and insensible when exposed for a few minutes to a temperature a little above that of the human body. This was carefully ascertained by using an incubator and a thermometer. The scorpion in the fiery circle lashes about with its sting, and then suddenly faints owing to the heat. If removed from the heat it recovers completely; but, of course, when it is supposed to have committed suicide, no one takes the trouble to remove it. I made, several times, the actual experiment of placing a large active scorpion within a ring-like wall, a foot in diameter, formed by live coals. The scorpion never stung itself. On one occasion it walked out over the coals, and on other occasions, after lashing its tail and running about, fainted, and became motionless.

Jelly-fishes are often called "sea-nettles," because of the microscopic poison-bearing threads which they discharge from their skin. These are used to paralyse their prey, and, in a few kinds only, are sufficiently powerful to cause a "stinging" effect when they come into contact with a bather's skin. Sea-anemones are also armed with these minute threads, and their poison has been extracted and studied. The spines of star- 
fishes and sea-urchins have a very deadly poison associated with them, which has recently been examined. Among insects we have the bees, wasps, and ants, with their terminal stings; caterpillars, with poisonous hairs; gnats, with poisonous mouth glands. Residents in mosquito-infested countries become "immune" to the poison of gnat-bite, but not to the deadly germs of malaria and yellow fever carried by the gnats. The centipedes have powerful jaws, provided with poisonsacs; the spiders have stabbing claws, fitted with poisonglands. Shell-fish, such as crabs and lobsters, do not possess stings or poison-sacs, but some of the whelk-like sea-snails have poison-glands, which secrete a fluid deadly to other shell-fish. We have already spoken of the poisonspines of fishes; among reptiles it is only some of the snakes which are poisonous, and are known to have poisonglands connected with grooved fangs. Only one kind of lizard-the Heloderm of North America, already mentioned-has poison-glands in its mouth, but it has no special poison-fangs, only small teeth. There is a most persistent and curious popular error to the effect that the rapidly moving bifid tongue of snakes and lizards is a "sting." It is really quite innocuous. No sting is known among birds, although some have fighting "spurs" on the leg, and "claws" on the wing.

Only the lowest of the mammals or warm-blooded hairy quadrupeds - namely, the Australian duck-mole (Ornithorhynchus) and the spiny ant-eater (Echidna)have poison-glands and related "spurs," or stings. They have on the hind-leg a "spur" of great size and strength, which is perforated and connected with a gland which produces a poisonous milky fluid. Recent observations, however, as to the poisonous character of this fluid are wanting. Many mammals have large sac-like glands, which open by definite apertures, in some cases between 
the toes, in others upon the legs, at the side or back of the head (the elephant), in the middle of the back or about the tail. The fluid secreted by these glands is not poisonous nor acrid, but odoriferous, and seems to serve to attract the individuals of a species to one another. They resemble in structure and often in position the poison-glands of the spurs of the duck-mole and spiny ant-eater.

Many insects produce a good deal of irritation, and even dangerous sores, by biting and burrowing in the human skin, without secreting any active poison. Often they introduce microscopic germs of disease in this way from one animal to another, as, for instance, do gnats, tsetze-flies, and horse-flies, and as do some small kinds of tics. The bites of the flea, of midges, gnats, and bugs are comparatively harmless unless germs of disease are introduced by them, an occurrence which, though exceptional, is yet a great and terrible danger. We now know that it is in this way, and this way only, that malaria or ague, yellow fever, plague, sleeping-sickness, and some other diseases are carried from infected to healthy men. Various diseases of horses and cattle are propagated in the same way. The mere bites of insects may be treated with an application of carbolic acid dissolved in camphor. The pain caused by the acid stings of bees, wasps, ants, and nettles can be alleviated by dabbing the wound with weak ammonia (hartshorn). Insects which bury themselves in the skin, such as the jigger-flea of the West Indies and tropical Africa, should be dug out with a needle or fine blade. The minute creature, like a cheese-mite, which burrows and breeds in the skin of man and causes the affliction known as the itch must be poisoned by sulphurous acid - $a$ result achieved by rubbing the skin freely with sulphur ointment on two or three successive days. A serious pest in the summer in many parts of England 
is a little animal known as the harvest-man. These are the young of a small red spider-like creature, called Trombidium. They get on to the feet of persons walking in the grass, and crawl up the legs and burrow into the tender skin. Benzine will keep them away if applied to the ankles or stockings when they are about, and will also destroy them once they have effected a lodgment.

FIG. 15 bis.-A. Highly magnified drawing of a stinging hair of the common nettle. The hair is seen to be a single cell or capsule of large size, tapering to its extremity, but ending in a little knob. The hard case $e$ is filled with liquid $a$, and is lined with slimy granular "protoplasm" b, which extends in threads across the cavity to the "nucleus" $c$. The ordinary small cells of the nettle leaf are marked $d$. B shows the knobbed end of the stinging hair, and the way in which, owing to the thinness of its walls, it breaks off along the line $x y$ when pressed, leaving a sharp projecting edge, which penetrates the skin of an animal, whilst the protoplasm $p$, distended with poisonous liquid, is shown in $\mathrm{C}$, issuing from the broken end. It would escape in this way when the sharp, freshly broken end had penetrated some animal's skin.

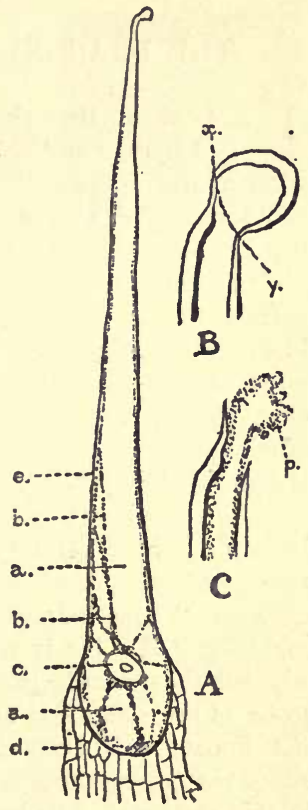




\section{XIII}

\section{THE DRAGON: A FANCY OR A FACT}

T AM about to write of loathly dragons, "gorgons 1 and hydras and chimæras dire." Every one knows what a dragon looks like, though probably most people could not give a minute description of the beast. A number of quite distinct creatures, some living on land, some in sea, are spoken of in the Bible by a word which is translated as "dragon." The ancient Welsh chieftains, like many fighting princes of old days, bore a "dragon" on their banners, and were themselves called "dragons" (Pen-dragon), and when a knight slew such a chieftain fabulous stories grew up as to his combat with and slaughter of a "dragon."

The complete, legitimate dragon of the present day is the dragon of heraldry, which is maintained in proper form and with authorised attributes by the Heralds' College. I have a drawing of this "official " beast before me (Fig. 16). $\mathrm{He}$ is represented as of large size, but whether theoretically the heralds of to-day consider him to be as large as a lion or ten times as long and tall I do not know. His body is lizard-like, and covered with scales resembling those of some lizards (unlike a crocodile in this respect). His head is not unlike that of a crocodile, excepting that he has a short, sharp horn on his nose, and a beard on his chin, and also a pair of large 
pointed ears which no living reptile possesses. His mouth is open, showing teeth like those of a crocodile, and from it issues a remarkable tongue, terminating in an arrow-head-shaped weapon (presumably a "sting") unlike anything known in any living animal. His tail is very long and snake-like (an important fact when we come to consider his ancestry), and is thrown into coils.

It terminates in an arrow-headshaped structure like that of the tongue, quite unlike anything known in any real animal. $\mathrm{He}$ has four powerful limbs, which are not like those of a lizard or a crocodile. They resemble those of an eagle, and have grasping toes and claws, three directed forward and one back-

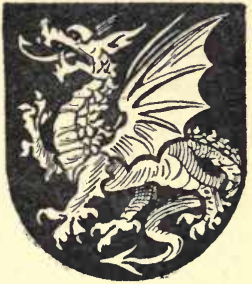
ward. In addition, he has a pair FIG. 16. - The heraldic of wings, which are leathery, and supported by several parallel bars, a structure which gives the wings a remote resemblance to those of a bat. The wing is quite unlike that of a pterodactyle (the great extinct flying lizard), and has no resemblance dragon : observe the batlike wings, the ears, the horned nose, the beard, the arrow-like tongue and tail-piece, the scaly body, the dorsal crest, the snake-like tail with its unnatural arrow-like termination. whatever to that of a bird, which is, of course, formed by separate quill feathers set in a row on the bones of the fore-arm and hand. The wings are always represented (even in illegitimate and Oriental dragons) as much too small to carry the dragon in flight. The dragon has, further, a crest of separate triangular plates set in a row along the mid-line of his back, extending from his head to the end of his tail. Some lizards (but not crocodiles) have such a crest. The most like it is that of the New Zealand lizard, called the Sphenodon.

Such is the creature called "the" dragon. But 
heraldry recognises some other terrible beasts allied to the dragon; in fact, what zoologists would call "allied species." The griffin, for instance (Fig. I 7), is

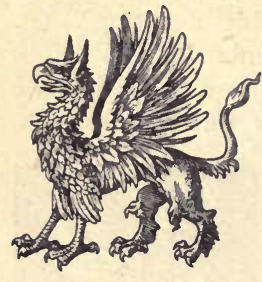

FIG. 17.-The heraldic griffin. It alone of the dragon-like monsters has feathery wings.

a four-legged beast like the dragon, but has the beak and wings and forefeet of an eagle, and the hind-legs and tail of a lion. The heraldic hydra is a dragon, such as I have above described, but with seven heads and necks. The ancient Greek representation of the hydra destroyed by Hercules (as painted on vases) was, on the contrary, based upon the octopus, or eight-armed cuttle-fish, each arm carrying a snake-like head (Fig. 1 8). The wyvern is an important variety of the dragon tribe, well known to heralds, but not to be seen every day. It so far conforms to natural laws that it has only two legs, the fore-limbs being the wings (Fig. 19). The true dragon and the griffin, like the angel of ecclesiastical art, have actually six limbs-namely, a pair of forelegs or arms, a pair of hindlegs, and, in addition, a pair of wings. Occasionally an artist (even in ancient Egyptian works of art) has attempted to avoid this redundance of limbs by representing an angel as having the arms themselves provided with an expanse of quill feathers. This

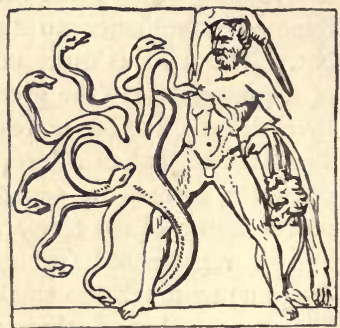

FIG. 18.- Hercules destroying the hydra (copied from an ancient Greek vase).

is certainly a less extraordinary arrangement than the outgrowth of wings (which in birds bats, and pterodactyles 
actually are the modified arms or fore-limbs), as an extra pair of limbs rooted in the back. The wyvern and the cockatrice and the basilisk (Fig. 20) (which, like the Gorgon Medusa, can strike a man dead by the mere glance of the eye) are remarkable for conforming to the invariable vertebrate standard of no more than two pairs of limbs, whether legs, wings, or fins. The name "lind-worm" is given to a wyvern without wings (hence the Linton Worm and the

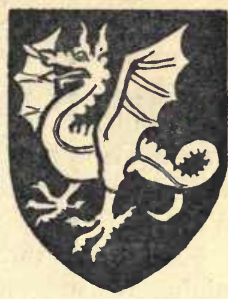

FIG. 19.-The heraldic wyvern.

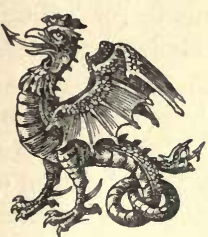

FIG. 20.-The heraldic basilisk, also called the Amphysian Cockatrice. Observe the second head at the end of its tail-a feature due to perversion of the observation that there are some snake-like creatures (Amphisbena) with so simple a head that it is at first sight difficult to say which end of the creature is the head and which is the tail.

Laidley Worm of Lambton), and appears in various heraldic devices and in legendary art; whilst in the arms of the Visconti of Milan we climb down to a quite simple serpent-like creature without legs or wings, known as the "guivre."

Without looking further into the strange and fantastic catalogue of imaginary monsters, one must recognise that it is a matter of great interest to trace the origin of these marvellous creations of human fancy, and the way in which they have first of all been brought into pictorial existence, and then variously modified and finally stereotyped and maintained by tradition and art. It has not infrequently been suggested, since geologists made us acquainted with the bones of huge and strange-looking fossil reptiles dug from ancient rocks, that the tradi- 
tion of "the dragon" is really a survival of the actual knowledge and experience of these extinct monsters on the part of "long-ago races of men." It is a curious fact, mentioned by a well-known writer, Mrs. Jameson, that the bones of a great fossil reptile were preserved and exhibited at Aix in France as the bones of the dragon slain by St. Michael, just as the bones of a whale are shown as those of the mythical Dun-cow of Warwick in that city.

There are three very good reasons for not entertaining the suggestion that the tradition of the dragon and similar beasts is due to human co-existence with the great reptiles of the past. The first is that the age of the rocks known as cretaceous and jurassic (or oölitic), in which are found the more or less complete skeletons of the great saurians-many bigger in the body than elephants, and with huge tails in addition, iguanodon, megalosaurus, diplodocus, as well as the winged pterodactyles (see Plate II., where a representation is given of what we know as to the form and bearing of two species of pterodactyle) and a vast series of such creatures-is so enormously remote that not only man but all the hairy warm-blooded animals like him, did not come into existence until many millions of years after these rocks had been deposited by water and the great reptiles buried in them had become extinct. The cave-men of the Pleistocene period are modern, even close to us, as compared with the age when the great saurians flourished. That was just before the time when our chalk-cliffs were being formed as a slowly growing sediment on the floor of a deep sea. No accurate measure of the time which has elapsed since then is possible, but we find that about $200 \mathrm{ft}$. thickness of deposit has been accumulated since the date of the earliest human remains known to us-whilst over $5000 \mathrm{ft}$. have accumulated since the 

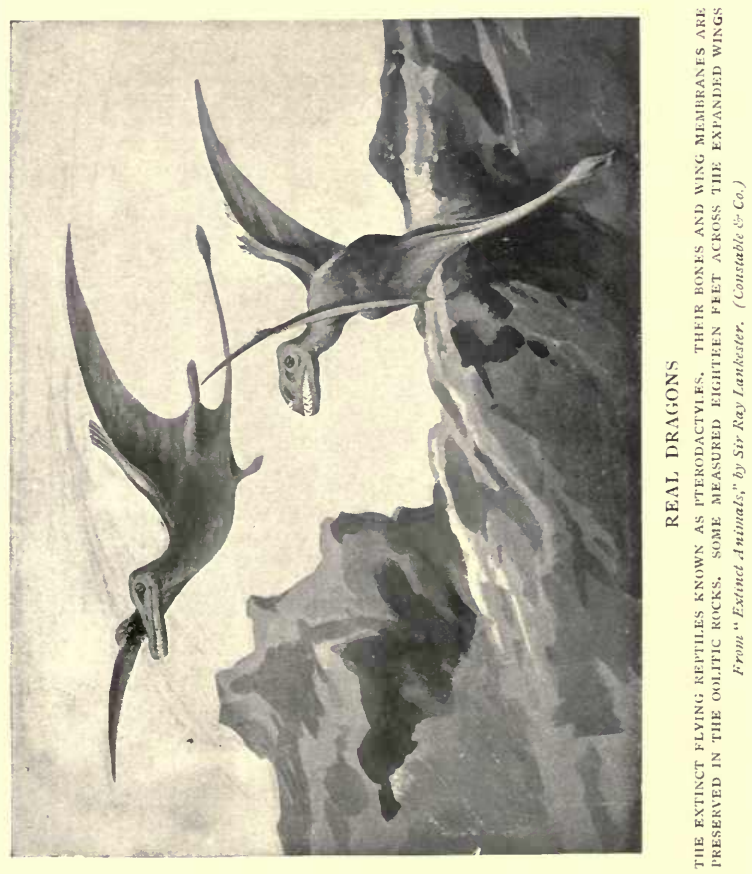

chalk began to be deposited, and the great saurians ceased to exist. If we reckon, in accordance with the most moderate estimate, a quarter of a million years for the upper $200 \mathrm{ft}$. of deposit or human period (Pleistocene), we must suppose that twenty or thirty times as long a period has elapsed to allow time for the deposit of the $5000 \mathrm{ft}$. of sand and rock since the great saurians ceased to exist. This would be some six or seven million years - a long while for tradition to run, even supposing man existed all that time, which he did not. And the probability is that this estimate of the time is far too small: a hundred million years is nearer the truth.

Suppose that man came into existence as an intelligent creature, capable of handing on a tradition, as much as half a million or even a million years before the date of the remains of the earliest cave-men discovered in Europe, we yet get no long way down the avenue of past time. Man would still be separated by millions of years and long ages of change and development of the forms of animal life on the earth's surface, from the period of the great reptiles or saurians who flourished before the chalk was deposited. And there is good evidence that none of those great saurians survived the date of the chalk. They died out and their place was taken by the earliest ancestors of elephants, rhinoceroses, horses, cattle, lions, and monkeys, from which in the course of ages the animals we know by those names were developed, whilst very late in the history man was produced. The reptiles continued as small, furtive creatures-the lizards and a few biggish snakes and crocodiles-but no descendants of "the great Dinosaurs" survived.

Another reason against the supposed survival of a real tradition of dragons is that, even in regard to much later-immensely later-creatures, such as the mammoth 
or hairy elephant, which we know was contemporary with man, there is no real tradition. The natives of the subarctic regions in which the skeletons and whole carcases of the mammoth are found in a frozen state, and from whence many hundreds of tusks of the mammoth have been since the earliest times yearly exported and used in Europe as ivory, have no "tradition" of these creatures. They have fanciful stories about the ghosts of the mammoths, but they call their tusks "horns," and have no legends of the monster as a living thing. The use of mammoth's ivory in Northern Europe dates back for a thousand years historically, and probably has never ceased since the days of the cave-men. Three years ago I examined the richly carved drinking horn of a Scandinavian hero, dating from the tenth century, and preserved amongst the treasures of York Minster, and I have little doubt that it is fashioned from the tusk of a mammoth.

A third reason for rejecting any connection of the dragon with a real reminiscence of the great extinct saurians is that its origin and its gradual building up in human fancy can be traced in the same way as that of many other fanciful and legendary creatures by reference to the regular operation of the imagination in successive ages of mankind. All races of men have imagined monsters by combining into one several parts of different animals. The centaur of the Greeks is a blend of man and horse, the great "divine" chimera of the Greeks was a two-headed blend of lion and goat, and any such mixed creature is technically called nowadays " a chimera". The dragon is classed by heralds as a chimera. Sometimes one of these imaginary beasts has its origin in a terrible or weird animal, which really exists in some distant land, and is celebrated or even worshipped by the inhabitants of that distant land, whose descriptions of it 
are carried in a distorted and exaggerated form to regions where it does not exist.

The dragon appears to be nothing more nor less in its origin than one of the great snakes (pythons), often $25 \mathrm{ft}$. in length, which inhabit tropical India and Africa. Its dangerous character and terrible appearance and movement impressed primitive mankind, and tradi-

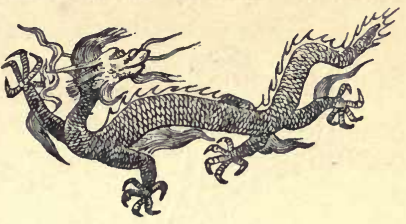

Fig. 21.-The Chinese Imperial Dragon, from a drawing on a tile of the old Imperial Palace of Nankin. It has five claws. No one outside the Imperial service may use it, under penalty of death. Ordinary people have to be content with a fourclawed dragon. Compare this with the European heraldic dragon, Fig. 16. tions of it have passed with migrating races both to the East and to the West, so that we find the mythical dragon in ancient China and in Japan, no less than in Egypt and in Greece. It retains its snake-like body and tail, especially in the

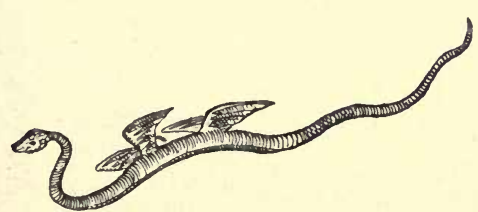

FIG. 22.-A flying snake with two pairs of wingsa "fabulous" creature thus drawn in an ancient Chinese work, the "Shan Hai King." This book dates from about 350 A.D., but probably is based on records of a thousand years' earlier date.

of its direful qualities. Chinese traditions indicate the mountains of Central Asia as the home of the dragon, whilst the ancient Greeks considered it to have come 
from the East. As a matter of fact, the Greek word "drakon" actually meant plainly and simply a large

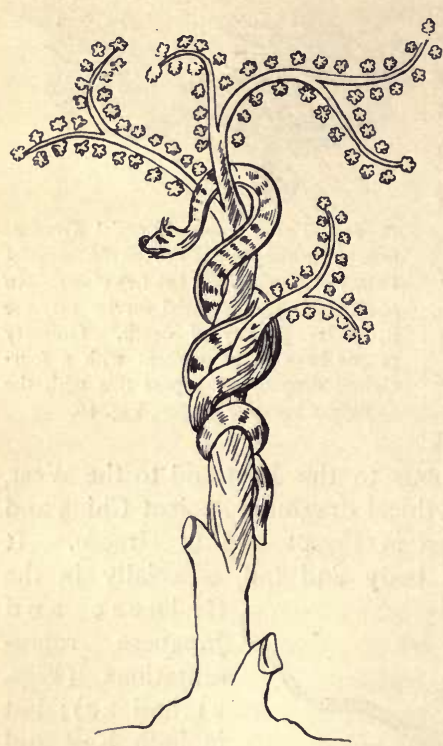

FIG. 23.-The dragon guarding the tree in the garden of the Hesperides on which grew the golden apples, in quest of which, according to Greek legend, the hero Hercules went. The drawing is copied from an ancient Greek vase, and the original includes figures of the Hesperides and of Hercules, not reproduced here.

exists, or has existed, in both the old world and the new. The Egyptians revered a great serpent-god called "Ha-her," or "great Lord of fear and terror"; to him 
the wicked were handed over after death to be bitten and tortured. The evil spirit in the Scandinavian mythology was a huge snake-and the connection, not to say confusion, of the terrible snake with the dragon on the part of the early Christians is shown by the words in Revelation xx. I, 2, "the dragon, that old serpent, which is the Devil, and Satan." The mediæval devil with goat's feet retained the dragon's tail with its curious triangular termination.

To the Greeks and Romans snakes were not such very terrible creatures, since the kinds found in South Europe are small and harmless-only the viper being poisonous - and they regarded the serpent as a beneficent creature, the familiar of Esculapius the god of medicine, companion of the household gods (the Lares), and guardian of sacred places, tombs, and concealed treasure (Fig. 27). The snake was the special earth-god, subterranean in habit, cunning, subtle, and gifted with powers of divination. The conception of the serpent as an avenging monster kept continually thrusting itself from the East into the popular mythology of the Greeks, and finally led to the building up of the dragon as a winged and clawed creature distinct from the harmless but cunning snake familiar to them. Even in India there arose a sort of double attitude towards the snake (as is not uncommon in regard to deities). On the one hand he was regarded as all that was terrible, destructive, and evil, and on the other as amiable, kindly, and wise. The services of the beautiful rat-snake in destroying house rats rendered him and his kind welcome and valued guests. In Egypt we find representations of small winged snakes without legs, and the ancient traveller, Herodotus, believed that they represented real creatures, as did the Roman naturalist, Pliny. Very probably the belief in winged snakes is due to the 
similarity of the snake and the eel in general form, since the paired fins of the eel close to the head (see Figs. 24 and 25 ) correspond in position with the wings shown in the Egyptian drawings of winged serpents. The particular form of winged snake pictured on Egyptian monuments (see Figs. 26, 27) appears to me to be a realisation of stories and fancies based on real experience of the locust. It was the terrible and destructive locust of which Herodotus tells_calling it "a winged serpent." The Egyptian

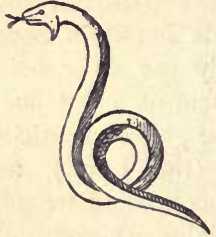

Fig. 24.-A votive

tablet (ancient Rome) showing what is meant for a snake, but has been "improved" by the addition of fins like those of the eel.

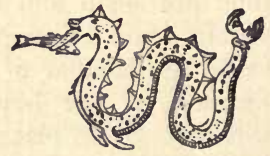

Fig. 25.-Ancient Roman painting of a so-called marine serpent-really an eel-like fish-inaccurately represented. The fins show how, from such pictures, the belief in winged serpents might take its origin.

pictures of winged serpents have wings resembling those of an insect (see Figs. 26 and 27), and sometimes they are represented with one and sometimes with two pairs.

Aristotle says that, as a matter of common report in his time, there were winged serpents in Africa. Herodotus, on the contrary, says there were none except in Arabia, and he went across the Red Sea from the city of Bats in order to see them. He did not, however, succeed in doing so, though he says he saw their dead bodies and bones. He says that they hang about the trees in vast numbers, are of small size and varied colour, and that 
they are kept in check by the bird known as the Ibis, which on that account is held sacred, since they increase so rapidly that unless devoured they would render it impossible for man to maintain himself on the earth. They invade Egypt in swarms, flying across the Red Sea. All this agrees with my suggestion that the winged "serpents" heard of by Herodotus were really locusts; and the creature drawn in Fig. 27 may well be a locust transformed by fancy into a winged snake.

It would be a very interesting but a lengthy task to trace out the origin and history of the various traditional

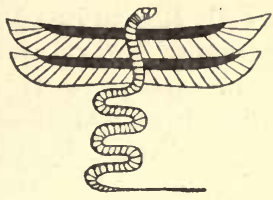

Fig.26.-Egyptian four-winged serpent-as drawn on ancient Egyptian temples.

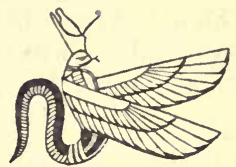

Fig. 27.-Two-winged serpent, symbolic of the goddess Eileithya, from a drawing on an Egyptian temple.

monsters, such as the basilisk, the gorgon, the cockatrice, the salamander, and the epimacus, which have come into European legend and belief, and to give some account of the special deadly qualities of each. St. Michael and St. George slaughtering each his dragon and rescuing a lovely maiden from its clutches are only appropriations by the new religion of the similar deeds ascribed to Greek heroes, such as Hercules, Bellerophon, and Perseus. Often a belief in the existence of a monster has arisen by a misunderstanding, on the part of a credulous people, of a drawing or carving showing a strange mixture of the leading characteristics of different animals, which was meant by the man who 
made it to be only symbolic of a combination of qualities. Just as the Latins and mediæval people credulously accepted Greek symbolic monsters as real, and transmuted Greek heroes into Christian saints, so were the Greeks themselves deluded by strange carvings and blood-curdling legends which reached them at various dates from mysterious Asia into a belief in the actual existence of a variety of fantastic monsters. "The Greeks," says M. E. Pottier, a distinguished French writer on Greek mythology, "often copied Oriental representations without understanding them." The conventional dragon probably came from Indian sources through Persia to China, on the one hand, spreading eastwards, and to the Latins of the early Roman Empire, on the other hand, spreading westwards; but at what date exactly it is difficult to make out.

In mediæval, as well as in earlier times, marvellous beasts were brought into imaginary existence by the somewhat unscrupulous enterprise of an artist in giving pictorial expression to the actual words by which some traveller described a strange beast seen by him in a foreign land. Thus the "unicorn," which was really the rhinoceros, was seen by travellers in the earliest times, and was described as an animal like a horse, but with a single horn growing from its forehead. The heraldic draughtsman accordingly takes the spirally twisted narwhal's tusk, brought from the northern seas by adventurous mariners (the narwhal being called "the unicorn fish ") as his unicorn's horn, and plants it on the forehead of a horse, and says, "Behold! the unicorn." Meanwhile the real "unicorn," the rhinoceros, became properly known as navigation and Eastern travel extended, and true unicorns' horns, the horns of the rhinoceros, richly carved and made into drinking cups, not at all like the narwhal's tusk, were brought to 
Europe from India. One was sent to Charles II. by "the Great Sophy," and handed over to the Royal Society by the King for experiment. These horns were asserted to be the most powerful antidote or destroyer of poison, and a test for the presence of poison in drink. There was no truth whatever in the assertion, as the Royal Society at once showed. Yet they were valued at enormous prices, and pieces were sold for their weight in gold. A German traveller in the time of Queen Elizabeth saw one which was kept among the Queen's jewels at Windsor, and was valued, according to this writer, at $£$ I 0,000 .

Credulity, fancy, and hasty judgment are accountable for the belief in mythical and legendary monsters. Yet they have great interest for the scientific study of the growth of human thought and of the relationships of the races of mankind. They are often presented to us in beautiful stories, carvings, or pictures, having a childlike sincerity and a concealed symbolism which give to the wondrous creatures charm and human value. 


\section{XIV}

\section{OYSTERS}

YSTERS are delicate morsels - still appreciated by that class of the population which nevertheless shudders at the thought of eating the high-flavoured "whilk" or the gristly "periwinkle," and neglects the admirable mussel, so rightly valued by our French friends. There are a number of interesting facts about the nature and life-history of oysters, and the different kinds of them-a knowledge of which does not diminish, but, on the contrary, rather adds to the pleasure with which one swallows the shell-fish. I remember the time when "natives" were sold in London at sixpence the score. When I was a schoolboy at St. Paul's they were no more than sixpence a dozen at the best shops in Cheapside. That inevitable form of British enterprise which is known as "monopoly," many years since laid hold of the oyster business, and rapidly raised the price of the best natives to eight times what it had been, while the typhoid "scare" came subsequently as a sort of poetical justice, and threatened to ruin the oyster monopolists. As a matter of fact, there is no difficulty in freeing oysters from any possible contamination by the typhoid germ. They have only to be kept for ten days or a fortnight in large tanks of sea-water of unquestionable purity-after removal from the fattening grounds (tanks 
or waterways), and they rid themselves of any possible infection. It is the interest of the oyster merchant to make sure that this treatment is strictly enforced. It is a noteworthy fact that the anciently established habit of drenching an oyster with vinegar before eating it is precisely the best treatment, except cooking them, which could have been adopted in order to destroy the vitality of typhoid germs-although the existence of such germs was unknown when the practice arose, and vinegar or lemon-juice was taken with uncooked oysters as a matter of taste, not as a safeguard.

The oyster is sometimes grandiloquently styled "the succulent mollusc" - and it is classed together with other bivalve shells and true "shell-bearing" shell-fish, such as whelks and snails (not lobsters and crabs, which are Crustacea), in a great division of animals known to naturalists as the Mollusca. This word is only a Latin form of the name Malakia, which was given to the cuttle-fishes by that wonderful man Aristotle, the Greekand means "soft creatures." A bivalve, or two-shelled mollusc, like the oyster, may be compared to an oblong notebook. The hard covers correspond to the two shells and the back to a horny piece by which the two shells are united, forming the hinge. If you place a piece of indiarubber (a thickish bit) between the covers of the notebook so that it lies near the back, and then try to shut the book, you find that it requires some pressure to do so; when you leave off pressing them the covers gape. The horny hinge-piece or ligament of the shells of the oyster and other bivalves acts in this way. The shells are only kept closed by a strong muscle, which runs across from shell to shell (Figs. 28 and $30 \mathrm{~m}$ ). When the oyster is at rest or when it is dead the muscle does not act, and the elastic hinge-piece or ligament causes the shells to gape. The animal within the shells 
may be compared to the leaves of the notebook. Suppose there are twenty-six leaves, then the outermost leaf on each side corresponds to the two soft living membrane-

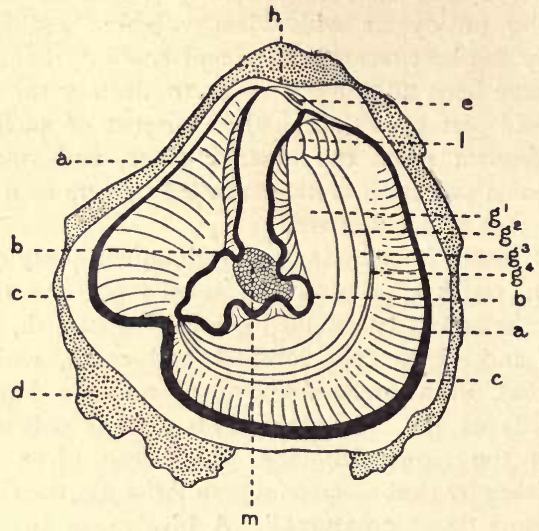

FIG. 28.-An oyster with the right-side shell removed; $c$, the pearly inner surface of the left-side shell ; $d$, the horny outer layer projecting beyond $c$; $a$, the thick edge of the "mantle"-flap of the left side; $b$, the thick edge of the mantle-flap of the right side thrown back towards the centre, so as to show what underlies it ; $e$, notch in the surface (pulled a little upwards and forwards) where the ligament is formed; $h$, the hinge urface, where the removed shell rested on the left-side shell; $g^{1}$ to $g^{4}$, the four gill-plates or flaps, two right two left-the so-called beard; $l$, the four corresponding lip lobes: the mouth lies deeply between the second and third - that is between the right pair and the left pair ; $m$, the central shell-muscle, which runs from one shell to the other.

ous flaps which secrete the two shells or covers of the oyster and lie closely on them ( $a, b$, Figs. 28 and 30 ); the next two on each side (rather shortened leaves, folded 
in from below) are the flat gills or "gill-plates" of the mollusc ( $g^{1}$ to $g^{4}$ in Fig. 28 ); whilst we must suppose the twenty middle leaves to be "pulped" and fused together to represent the body of the shell-fish.

The oyster's gill-plates, commonly called "the beard," are covered on the surface by microscopic hairs of a very remarkable kind (Fig. 29). They are soft, living protoplasm, and are continually "lashing," bending forwards and straightening again at the rate of some three or four hundred strokes to the minute. They all work rhythmically together, and produce a strong current in the water, which

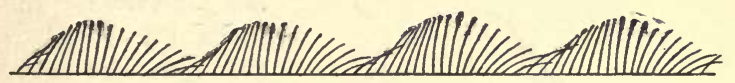

FIG. 29.-Part of a row of the lashing hairs or " cilia" which cover the gills of the oyster. This represents part of a single row, only the $\frac{1}{4} \frac{1}{0}$ th of an inch long from one end to the other. The whole surface of the gill and other parts is beset with these hairs, not in single rows, but closely, as the hairs of fur are set. The drawing is intended to show the way in which the hairs actively bend downwards (or "lash"), and then rise up again in regular waves, the movement or wave passing along in the same way as a wave of bending and returning to the upright passes over a ripe cornfield when a light breeze blows across it (see also Fig. 40).

bathes the surface of the oyster when the shells are open. Such microscopic vibrating hairs are very common in aquatic animals, and are called "cilia." The current which they produce causes oxygen-holding water to flow from without over the gills, and so aerate the blood of the oyster, and also carries into the chamber protected by the shells excessively minute particles, chiefly microscopic plants, which are driven on to the small, open mouth of the oyster, placed far up on its body. These microscopic food-particles are wafted down the oyster's throat by similar vibrating hairs into the stomach and intestine. An oyster has no other means of taking food, and almost without cessation, as the oyster lies on the sea bottom 
with its muscle relaxed and its shell "gaping," the nourishing stream is kept going. If poisonous matter, bad water, or some violent disturbance make themselves apparent, the shell-muscle acts, and the oyster tightly closes his shell. Such things make themselves " apparent" to the oyster, for it has a nervous system, and though it has no eyes (the nearly allied "scallop" has a number of eyes) it has a delicate sense of smell and touch, and also what is usually considered to be an organ of hearing.

The oyster has also a heart and blood-vessels (Fig. 30)

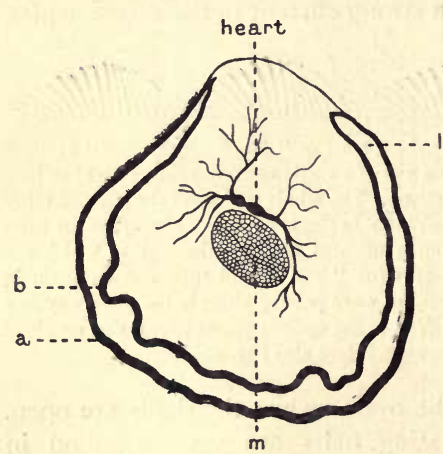

FIG. 30.-The animal of an oyster removed from the shell : $a$, the thick edge of the left side mantle-flap or skirt; $b$, same of the right side; $l$, position of the mouth; $m$, shell-muscle or adductor-muscle, bringing the two shells tightly together when it contracts.

itself in the summer. Our north European oyster produces in the same individual both egg-cells, and the male fertilising sperm-cells or spermatozoa. The eggs are just visible to the unaided eye (Fig. $3 \mathrm{I}$ ), and as many as a million are produced in the warm breeding season by a

and blood; in some few bivalves and snails the blood is red like our own. The beating of the heart may be seen by careful examination of a freshly opened specimen. The oyster has also a "liver," or digestive gland, and a kidney and a soft, branched, tubular structure embedded in the body, within which the egg-cells and sperm-cells grow by means of which the oyster propagates 
single ripe oyster, About a fortnight after the eggs have been shed, the same tubular chambers in the oyster's body which produced the eggs by growth from their inner walls, produce the spermatozoa, so that they are too late to fertilise the eggs of the same oyster. They pass out of the oyster into the sea water, and are carried within the

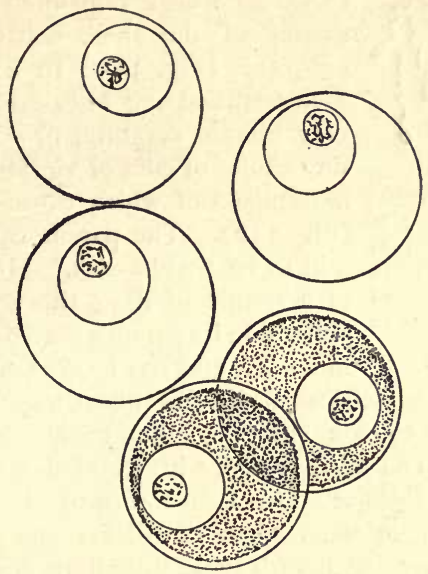

FIG. 31. -The eggs of the oyster-taken from a ripe individual-magnified 500 times linear.

shelter of the shells, and so on to the surface of the protected bodies of other neighbouring oysters by the currents created by the "ciliated" gill-plates of these neighbours.

The sperm particles or spermatozoa (Fig. 32) are produced by millions, and form a cloud finer than dust in the sea water. They are carried within the shells of both egg-producing and sperm-producing oysters, and are 
driven along into the openings of the tubular reproductive sacs, and into those sacs in the case of those oysters

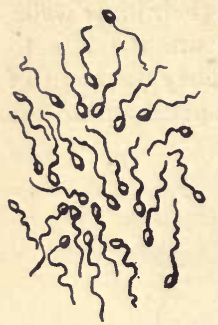

FIG. 32.-The sperms or spermatozoa of a ripe oyster, as seen swimming in a drop of sea water : magnified 2000 times linear.

which are at the time producing eggs. There they fertilise the eggs. The minute eggs begin to develop whilst still within the parent's body, and continue to do so whilst remaining within the shelter of the shell, adhering to the gill-plates (Fig. 33). In a day or two each fertilised egg has developed into a very minute creature, provided with a tiny circlet of cilia or vibratile hairs, the movements of which cause it to swim (Fig. $33 \mathrm{~F}$ ). The parent oyster is now said to be "white-sick." In the course of a couple of days the young oyster still within its parent's shell becomes dark in colour, and has formed on its surface a pair of symmetrical shells, not like those of an adult oyster, but convex (Fig. 34) like those of a clam or a cockle. The head region, with its circlet of vibrating cilia, can be projected between the open shells or withdrawn between them when the shells are shut: The mother oyster, laden with these little dark specks, is now said to be "black-sick."

In the course of a week or so the brood of dark young oysters escapes by thousands from the parent's shell into the surrounding water. They swim by their circlet of vibrating hairs, or "velum," as it is called, towards the surface, and are carried far and wide by the tides. They are active, transparent little "dots," very unlike their parent (Fig. 34). The next thing that happens to them-after a few days, perhaps weeks-is that owing to the increasing weight of their shells, they sink to the bottom. More than half perish by dropping 
A
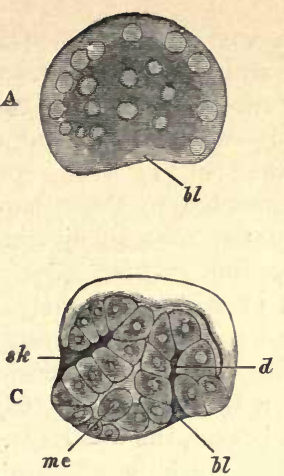

B
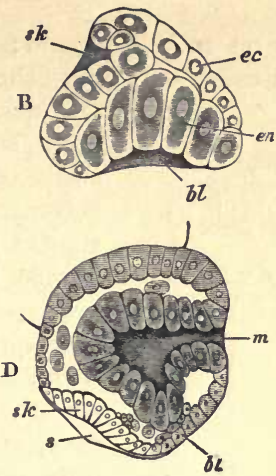

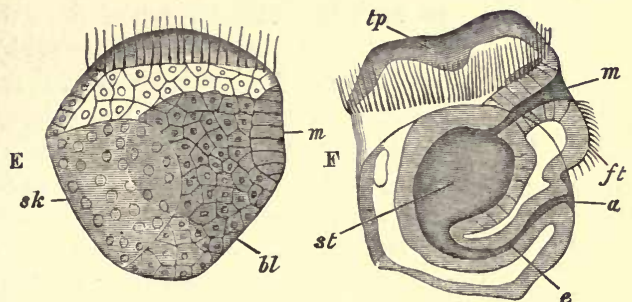

FIG. 33.-Development of the egg of the common oyster, after fertilisation within the tubular passage of the reproductive sacs. A, surface view. B, section through a very early stage-the separate cells or protoplasmic corpuscles which have resulted from the dividing up of the fertilised single egg-cell are seen; $b l$, in-pushing to form the gut; $s k$, in-pushing to form the rudiment of the double shell. C and D, the same a few hours later. The mouth, $m$, is now seen. $\mathrm{E}$, still later stage surface view : a ring of cilia has appeared. $F$, the young free-swimming oyster nearly ready to leave its mother's protection, who is now laden with such young, and is said to be "white-sick." The top of the head, $t p$, is now well marked and surrounded by a ring of lashing cilia. The outline of the right-side shell is seen, and the foot, $f t$, between the mouth, $m$, and the arius, $a$. The stomach, st, and the intestine, $e$, show by transparency. 
thus on to bad ground; a vast number have already been eaten by young fishes and shrimps. Those which

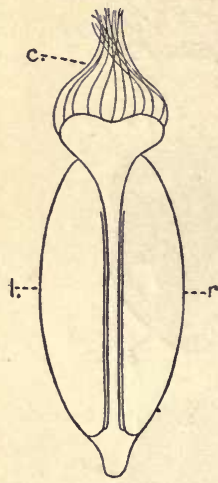

F I G. 34. - F r e eswimming young oyster or oyster. larva, showing the head, with its tuft of cilia projecting from between the two shells, $l$ and $r$. are lucky enough to fall on to something hard-stones, rocks, old oystershells, or the shells of living oystersbecome cemented to those hard substances by the new shelly substance formed by the growing edge of the lowermost of their little shells, which now spread out, lose their cockle-like shape as they grow, and become, the one (the left by which it is fixed) large, deep, and bossed, the other flat. The little oysters are only one-fortieth of an inch in diameter when first they become fixed, but they grow rapidly, feeding in the same way as their parents. Vast numbers are eaten by other animals. In some localities in two years, in others in three years, they have grown to a couple of inches in length, and now produce in the summer breeding season a certain quantity of eggs and sperm to start new generations. The oyster continues to grow, and at five to seven years of age is in full vigour and maturity; at ten years of age it produces few eggs, or sperm-cells; and in the course of another year or so, under natural conditions, dies.

Enormous as is the output of young by a single oyster-amounting to something like a million a year in probably four or five successive years-yet it must be remembered that on the whole, taking all the various oyster-beds into account, some of which increase whilst others dwindle or actually die out altogether, there is no 
increase in the oyster population of the seas. Taking them all round, five million young oysters start life in order that one may finally come to maturity, so many and varied and incessant are the dangers, the predatory enemies, the destructive effects of cold currents, bad ground, and other chances of life and death on to which the swarming swimming young are launched.

The above brief history applies to the North Sea or Channel oyster, which is also found (with other species) in the Mediterranean. The American and the Portuguese oyster differ from it in being of distinct sexes, and in the fact that the eggs are discharged into the sea by the females, and are there fertilised by the sperm discharged by the male oysters, instead of in the parent's body.

Other "molluscs," such as snails and whelks, enclose their fertilised eggs, when they lay them, in egg-shells. Some snails enclose a single egg in a shell which is filled up with clear liquid_corresponding to the "white" of a bird's egg-in which the egg floats and develops. The eggs of the common snail are not bigger than a hempseed, but some Indian snails lay eggs as big as those of a robin, with a hard, calcareous shell, and the young snail has quite a large coiled shell of its own before it escapes from the egg-shell. So that it looks, when one of the big snail's eggs is broken, as though a snail had managed to get inside a bird's egg without making a hole in it! The whelks and their kind lay many eggs in one shell or capsule, and the sea-slugs produce a sort of firm jelly, in cords like vermicelli, the jelly enclosing hundreds of little sacs filled with liquid, in which the true germs or fertilised egg-cells float. These are all methods for protecting the young in their earliest condition. One of our pond-snails - the Paludina - keeps her eggs, whilst they develop, inside the dilated end of the tube which leads from the egg-producing organ or ovary to the exterior, 
The young snails nearest the opening to the exterior are the furthest advanced in development, and are as big as a dried pea. All stages, from the minute germ just fertilised to well-formed young, may be found in these snails, and the whole course of their development and gradual change and growth can be minutely studied with the microscope in one specimen.

Similar devices for protecting the young in their earliest helpless stages of growth from the egg-shell are found in all classes of animals. What is very curious is the fact that, of two closely allied animals, one species will recklessly lay its eggs and leave them, whilst another has special arrangements for retaining in the parent's body the eggs as they develop, and so preserving them from danger. Such parents are called "viviparous." Of course, in all viviparous animals, as well as in those which lay their eggs in hard shells, the fertilisation of the egg must be effected within the maternal body. Amongst our common fishes there is the viviparous blenny, often found in pools at low tide on the seashore. All the other British fresh-water and marine fishes lay their eggs and abandon them, excepting some sharks, dog-fish, and skates, which are viviparous; others of the shark and skate tribe lay eggs of large size encased in hard, horny shells. Every one knows that frogs and toads lay their eggs, but there are some kinds in which the eggs remain inside the mother's body during the development of the young, which only escape into the world as well-formed little frogs. All the hairy, warm-blooded quadrupeds known as "the mammals" are viviparous, except the duck-mole and the spiny ant-eater of Australia. These extraordinary little " beasts" lay eggs like those of a bird.

The most ingenious devices for the protection of the young are (as perhaps those who believe in the superior 
intelligence of the male would expect) put into practice by the male parent. Thus, there is a large fish in tropical rivers which takes the eggs laid by the female into his capacious mouth, and swims about with them for three or four weeks, giving them the advantage of a current of water which runs through his mouth to his gills. When the young hatch they swim out of their fond father's mouth. The male of pipe-fishes and of the little "sea-horse" receives the eggs laid by the female into a pouch excavated along his ventral surface. There the young hatch, and are guarded by the nursing father. On the other hand, some fathers impartially eat their own young, as well as those of other parents, and the mother has a hard job to protect her offspring. A female octopus (the poulp or eight-armed cuttle-fish) sits over her eggs in a nest built of pebbles at the bottom of the sea (or of an aquarium tank in the instance studied by me many years ago at Naples), and squirts a stream of pure sea-water over them. She resents the approach of a fish or a crab or a landing-net with splendid fury and recklessness of attack. Often the males of fishes, frogs, and birds guard the eggs, or guard the nest where the female is occupied in caring for the eggs or the young.

There are various species of oysters common in all parts of the world which are eaten as delicacies. Primeval (Neolithic) man ate oysters (the common sort) in Denmark in enormous quantity-great heaps of the discarded oyster-shells are found, buried among which are discovered stone axe-heads and bits of rude pottery. In the West Indies travellers relate that the oysters "climb" the trees which overhang the water of quiet creeks and inlets of the sea. The fact is that the branches of the mangrove trees dip into the water, and the young oyster "spat" attaches itself to the immersed twigs. After a year or two, the tree grows vigorously, 
and raises its branches up in its growth, so that the oysters are carried far up above the sea waves. Of course they die under these conditions, but their position suggests the explanation that the oysters have climbed up the trees. Ship barnacles fix themselves, similarly, to the twigs of willow trees in the quiet sea lochs of the West of Scotland, and this led 500 years ago to the belief that the catkins of the willow tree ripen into barnacles. Since it was also held that the little animal of the barnacle hatches out of its shell as a young goose -the so-called "barnacle goose"-the marvellous story was believed that these geese are actually budded from willow trees. I believe that the supposed relationship of the goose and the ship's barnacle arose solely from the accidental similarity of the names of the two animalsthe "bernack" goose and the sea "barnacle" being names of independent origin. The names were different originally in sound and signification, but were corrupted by fisher-folk into one and the same word. Hence a fantastic fable took its growth.

In Paris you may test and compare several local varieties of the common oyster in a celebrated oystershop. There are Courseilles, Cancales, Marennes, Ostend, Zeeland, Arcachon, English natives, Côtes Rouges (red banks), and Black Rocks. And you can eat sea-urchins there, too, if you wish. They have not, however, got the celebrated oysters from the Lake Fusaro, near Naples. This was the ancient Acherusia palus, and in the neighbouring Lake Avernus and the Lucrine lake oysters were cultivated by the ancient Romans, the young oysters being made to affix themselves at "the fall of the spat" to wooden "stands" or frames, which were then placed in the lake (a salt-water lake), where they had abundant minute vegetable food and grew large and fat. The same cultivation, with the same shape of "stands," 
is carried on at the present day in the Lake Fusaro. My friend, Mr. Günther, of Magdalen College, Oxford, has published pictures of Roman tiles from this neighbourhood showing the oysters adhering in rows to the wooden frames. These tiles were apparently sold to holiday visitors in the time of the Roman emperors as a memento of a happy day spent at the Lucrine lake, just as a sugar basin or a mug is now sold at our seaside resorts with the inscription, "A present from Margate," or Southport, or Blackpool, and the picture of a shrimp above it.

The care of the breeding oyster and the plans adopted by the owners of oyster-beds for catching the "spat," or young oysters, when they fall to the bottom, by placing movable tiles or frames for them to fix themselves to, form an important part of the craft of the oyster-man. It is a difficult business, and is variously carried out in England, France, Holland, and America. The young oysters, when they have fixed themselves, are carried on the movable tiles or frames from one region to another for the purpose of encouraging their growth and avoiding a variety of dangers to their life and health (sometimes from the Bay of Biscay to the mouth of the Thames!). They are often-but not always-finally fed up in sea-ponds or inlets, which are peculiar in containing an enormous number of those very minute microscopic plants, with beautifully shaped siliceous shells, which are known as diatoms. These are so abundant in such ponds as to form a sort of powder or cloud near the bottom, and the oysters draw them, day and night, by their gill-currents into their mouths, digest them, and grow fine and fat. The district of Marennes, on the west coast of France, is celebrated for having seaponds or tanks in which a wonderful diatom of a bright blue colour abounds; so abundant are they that the 
cloud produced by them in the pools is of a deep cobaltblue. When oysters are placed in these tanks to fatten, their gills or beards become rich blue-green in colour. They lose the colour after ten days, when removed to ordinary tanks. These are the celebrated green oysters or "Marennes vertes" of French restaurants. The colouring matter of the little diatoms-swallowed by the million and digested-is taken up by the blood of the oyster from its stomach, and is excreted by certain corpuscles on the surface of the gills-as I showed some twenty-five years ago-just as red madder is deposited in the bones of a pig fed upon madder, and as the feathers of the canary take up the colour of cayenne pepper when it is mixed with the canary's food. It used to be thought that the green colour of the green oyster is due to copper-and that opinion was supported by the curious fact that the blood of all oysters and other molluscs, and also of lobsters, scorpions, and king-crabs, does really contain a minute quantity of copper, just as our blood contains iron! It was also supported by the fact that occasionally a fraudulent fishmonger, when asked to supply green oysters, has been convicted of colouring the beards of ordinary oysters with green copper salt, so as to imitate the real article! The real history of the green-bearded oysters is now quite certain, and any one interested in the matter should look at the coloured pictures of the beautiful little blue-coloured Navicula ostrearia - the diatom on which this oyster feeds, published by me in the Quarterly Journal of Microscopical Science in 1885 . 


\section{XV}

\section{MATERNAL CARE AND MOILUSCS}

THE American and Portuguese species of oysters, which are called respectively Ostrea virginiana and Ostrea angulata, as opposed to the common oyster, which is known as Ostrea edulis, are not hermaphrodite like the latter, but have distinct males and females. Moreover, the young are not fertilised within the parent's body, nor do they pass their earliest stages of growth within the parent's shell adhering to the "beard," or gills, as in the common oyster. The eggs (Fig. 3I) are, on the contrary, discharged by the females into the sea, and at the same time the males discharge a cloud of microscopic sperm filaments, or spermatozoa (Fig. 32), which dart about in the water and fertilise the eggs. That is a more prodigal and less certain process than that pursued by the common oyster. The American and Portuguese oyster have to pay for it. The female produces in one season not a million eggs, as does the common oyster, but nine millions. And out of every fifty million so produced (in some five or six years) only a single male and a single female individual, taking the whole oyster population of these species into consideration, survive to maturity.

This enormous excess of egg-production in order to ensure the survival of a single pair to replace their 
parents is a very frequent thing in aquatic animals. But there are many devices by which the necessity for such lavish scattering of a new brood is avoided. The common oyster is already a step in advance of the American in this matter, since it protects its young in the very earliest stages within the shelter of its shell. A further advance in this direction is found in the fresh-water mussels (not to be confused with the very different sea-mussels, since they are bitter and tough, and quite inedible, though used as bait in sea-fishing) The pond-mussel (Anodon) and the river-mussel (Unio) are of distinct sexes, and the gills of the female become swollen up at the breeding season so as to form two large bags, into which the eggs are laid by her, as many as 500,000 in number. They are fertilised by the sperm filaments discharged by the males, which are carried into the female's shell by currents produced by the vibrating hairs on the gills, as in the common oyster. But the young remain much longer in the mussel's gills than do the young oysters in those of their parent's. Late in the season you find the bag-like gills of the female pondand river-mussels full of extraordinary little creatures one-thirtieth of an inch long, each provided with a pair of triangular shells. They are discharged into the water, and swim very actively by rapidly opening and shutting the little shells (Fig. 35). The common scallop (Pecten, or Pilgrim's shell) swims every now and then in the same way as do these young mussels, and so do some other bivalves. The young fresh-water mussels produce a long, sticky thread, which trails from the shell (Fig. 35 by). Very few have the good chance to get further on in life than this stage, for all depends on their stumbling across fish-a stickleback, or a perch, or a pike-as they blindly snap their shells and wobble through the water. The lucky triangular mite whose sticky thread happens 
to touch a fish's body becomes immediately fastened by it to the fish and then grips the skin with its snapping shells, the edges of which are provided with a few long, sharp teeth. The fish probably is quite unaware of the lodgment of the young mussel on its skin, but there it remains, and gets buried for a time in the soft tissues of the fish, becoming thus actually a parasite for some two or three months during the winter season. It nourishes itself on the juices of the fish, and grows to
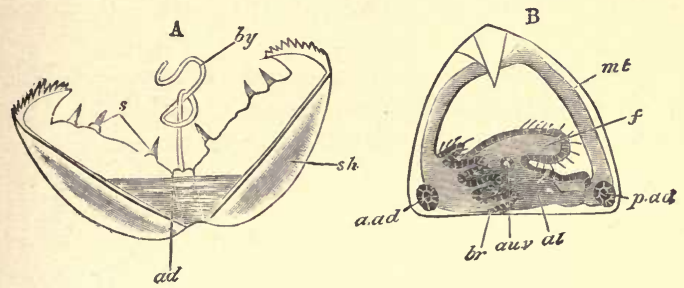

FIG. 35.-Young of the pond-mussel after escaping from the maternal gill-pouch : A, as it escapes, swimming by opening and shutting the shells ; sh, shell of one side ; $a$, shell-muscle ; $t$, teeth of the shell's edge ; $b y$, adhesive filament. $\mathrm{B}$, after it has fixed to a fish ; $m t$, mantle ; $f$, muscular foot ; $b r$, gill processes ; pad, aad, al, muscles ; $a u v$, heart. (From drawings by the late Frank Balfour.)

the size of a pin's head, whilst it is carried away from its birthplace by the peregrinations of its host, the fish. Its shell now ceases to be triangular, and becomes like that of its parents. Eventually the young mussel drops off the fish and rests on the muddy bottom of pond or river, where it remains for many years, growing vastly in size, and barely moving during its long life from the spot where it fell.

A beautiful little bivalve common in weedy streams in England is known as Cyclas (it has no English name); it has a pair of shells shaped like those of a cockle, but 


\section{SCIENCE FROM AN EASY CHAIR}

smooth, and only half as big as one's little finger-nail. The nursing of the young in the gill-sacs is carried to a much further point by Cyclas than by the pond-or river-mussel. Before they are ejected by the parent they are quite large-like their parent in appearance, and half as big as a hemp-seed. Necessarily there are not many produced in a season-there is not room for more than twenty or thirty young in the gill-sacs. 


\section{XVI}

\section{THE HEART'S BEAT}

THE beat of the heart is one of those great and elemental features of man's life which, in spite of our familiarity with it and its momentary recurrence, never loses its quality of mystery and isolation. The ceaseless accompaniment to our lives which the heart is always beating, like the inexorable stroke of an unseen pendulum, fills even the stoutest and bravest at times with a sense of awe. It seems now and then as though an independent living thing were in our breasts, and when it quickens and struggles, as it were, with its work, or languishes and hesitates in its efforts we have a sense of helpless domination by an existence-a living thingover whose vagaries we have no control.

The heart of man is no special endowment of the human race, nor even of the higher animals. As I mentioned a few pages back, the oyster and other shell-fish have a heart which keeps time and beats the seconds for their uneventful lives, as does that of man for his more varied career. Not only the molluscs, but the insects, the spiders, the crabs, lobsters, and shrimps, and even the worms, have each a rhythmically beating heart. In all of them the significance of this heart and its beat are the same-it is driving the nourishing, oxygen-carrying blood through the great vessels (arteries), which 
branch from it like a tree into the living tissues of the body, whence it returns by other vessels (the veins) back to the heart.

In man and the warm-blooded quadrupeds, in birds, reptiles, and fishes, the blood is of a splendid red colour, and the transparent vessels can be easily traced in their graceful ramifications and intricate networks, in consequence of the red blood showing through their walls. The red colour is due to a peculiar body, which can be easily separated from the blood as crystals. It has the special duty of carrying oxygen gas dissolved and attached to it; and of giving up that essential element to cause slow burning or oxydation in all parts of the body whilst taking up fresh supplies of oxygen on its passage through the lungs or the gills. In many of the lower animals (for instance, the oyster) the blood is devoid of this red crystalline substance (which, by the bye, is called hæmoglobin), and accordingly we cannot easily catch sight either of the heart or the blood-vessels (see, however, Fig. 30). But in shell-fish the blood has a very pale blue tint, and this colour is due to a substance like hæmoglobin, which also can be crystallised, and is the oxygen-carrier. Some sea-worms have a green substance of a similar nature dissolved in their blood, and one can trace their blood-vessels as a beautiful green network. A good many worms, for instance the common earth-worm and the leeches (a discovery made by Cuvier, and referred to by him on his deathbed), and many seaworms have deep-red-coloured blood, due to the presence of the same crystalline substance which we find in man's blood. And even a snail, common in the ponds at Hampstead and such places-the flat coiled snail known as Planorbis - has blood of a fine crimson colour, due to the presence of the same red oxygen-carrier, as an exception to the colourless or pale-blue blood found in most 
shell-fish. Perhaps if oysters, too, had red blood, there would be a prejudice against eating them in the uncooked condition.

The heart is essentially an enlargement of the great stem or main blood-vessel which, like the trunk of a tree, has branching roots at one end of it and ordinary branches at the other. The trunk branches, and roots of the "heart-tree" are, of course, hollow blood-holding tubes, not solid fibrous structures, as are the woody branches and trunk of a vegetable tree. Further, the finest rootlets and the finest terminal branches in the case of the heart-tree are connected to one another by the network of very fine branches or by great bloodholding cavities, which occupy all parts of the body of an animal. The enlarged part of the trunk of the tree-like system of blood-vessels - the heart-has powerful muscles forming its walls, the fibres disposed so as to surround the contained chamber. When these muscular fibres contract, they squeeze the walls of the chamber together and drive the blood out of it into the forward branches, called "arteries." It is prevented from going backwards into the hinder branches called "veins" (which we compare to the roots of a tree) by flaps which are so set on the inside of the great vessel at the entrance to those branches that the flaps are made to move out across the space by the backward current, and thus prevent any backward flow, whilst a forward current merely presses them flat against the wall of the vessel, and thus no obstruction to a forward flow is presented. These flaps are called the valves of the heart. The consequence of this arrangement is that whilst blood flows freely into the heart from the veins or hinder (root-like) set of vessels, it is driven by the muscular contraction of the heart-only in one direction-namely, forwards into the arteries. This movement in one 
direction is helped in some elongated hearts by the contraction of the wall of the heart beginning behind and spreading quickly forward like a wave. The heart of the common earth-worm and of small transparent worms with red blood like it, which are common in the mud of ponds and rivers and can be easily watched with the microscope so that one can see through their glasslike skin what is going on inside them, shows very beautifully this wave of contraction. The heart in these worms is a long contractile vessel which runs the whole length of the body along the back. You can watch the red blood flowing into it through the veins in each ring or segment of the worm's body-slowly swelling it out -so that it looks like a long red cord. Then, suddenly, there is a movement like a flash in its rapidity, passing from behind forwards! The walls of the red cord-like heart contract so as to drive the blood forward into the arteries, which also are present in every ring of the worm's body. At the same time you can see the . valves, which hang at the entrance of the veins to the heart, swing with a sudden "chuck" and close those vessels against the driven blood. The red cord becomes colourless progressively from behind forwards, owing to the squeezing out of the blood, and by the time the movement has reached the head of the worm, the hinder part of the cord-like heart is beginning slowly to dilate again with the influx of red blood from the veins.

What causes the muscles of the heart to contract at regular intervals? There is no doubt that the "stimulus" which excites the heart muscles to contraction is in these simpler animals merely the tension or strain produced by the presence of a sufficient quantity of blood which has flowed into the heart from the veins. The heart muscle, after its rapid contraction, rests; it has no other rest, no sleep, as have all the other parts of the body. It must 
rest and take refreshment after each effort. Whilst it rests the blood quietly flows in and dilates the heart's cavity; then the rested muscular wall of the heart, gently stretched by the recovery after compression of its elastic components, nourished and oxygenated by the blood, is ready for another "stroke," and again it contracts tightly, emptying its cavity of blood, which is driven into the arteries. So it goes on-effort and rest, effort and rest alternating without cease. Whilst it is the stroke of the heart which causes the blood to flow through the arteries into the finest neiwork of hair-like vessels, what is it that causes the blood to flow on through the collecting veins, to reach the heart, and actually to distend that collapsed cavity after its stroke? It must be remembered that a very low pressure is enough to effect this. In the simplest arrangements of worms and such-like animals, there is probably some pressure transmitted to the blood in the veins by the heart-stroke ; but the elasticity of the heartwall and its necessary tendency to resume its dilated condition after its squeezing by its rings of muscle, is what is chiefly effective in drawing on the blood in the veins into the heart.

In man and the higher animals the whole mechanism of the heart is greatly complicated by the action of the nervous system upon it and upon the contraction or expansion of the blood vessels. In this way the rate of the beat of the heart is affected and brought into relation with the needs of the blood circulation in remote parts of the body. The beat of the heart in the human species is more rapid in children than in adults, and more rapid in women than in men, and it differs in all individuals under differing conditions. Before birth it is 140 per minute, in the first month after birth 130 , and gradually diminishes to 90 at nine years of age, and at twenty-one to 70 in man and to 80 in woman. But these figures only repre- 
sent a general average; there are hcalthy men whose pulse usually is less than 45 per minute, and there are individuals who, without being invalids, yet have the movement of the heart so liable to increase in rapidity through mental or other excitement, acting by nerves directly on the heart muscle, that the pulse often goes up to I 2O. In the horse and the ox the pulse or heart beat is 36 to 40 a minute; in the sheep 60 to 80 ; in the dog 100 to 120 ; in the rabbit I5O; and in small creatures, like mice and moles, 200 , and even more! I do not know what is the record for the elephant, but as it seems that the larger the mammal the slower the pulse, one would not expect more than 20 to 25 beats a minute in his case.

It is easy to watch the beating of the heart of a flea or other small insects-under the microscope-since the skin is sufficiently transparent. It is not usually much more rapid than in man, but in the very transparent little fresh-water shrimps which are called water-fleas (Entomostraca) I have seen the heart beating so rapidly that I could not count its rate. The heart in insects and shrimps and their like is remarkable for the fact that whilst it pumps out blood through arteries both in front and behind, it has no actual veins opening into it. All the veins, which in their ancestors entered the heart in a row on each side of it, have united, and their walls broken down, so that the heart lies in a sac full of venous blood from which it draws its fill, when it dilates, through a series of valvebearing openings on its surface, openings which, in an earlier stage of development, were connected with individual veins.

The heart of the Ascidians or sea-squirts, common sac-like marine creatures of most varied form, size, and colour, is perhaps the most extraordinary in the whole animal series. I have often watched it in transparent 
individuals of this group. It is an oblong sac with branching vessels at either end. It beats for some thirty or forty strokes so as to drive the blood forwards; it then pauses, and the onlooker is astounded to see the wave of movement changed, and the heart steadily beating the same number of strokes in the reversed direction. What were arteries become veins, and the veins become arteries. Then again there is a pause-which seems like a moment of hesitation and doubt-and the original direction of movement is resumed; then again there is a pause and a reversal, and so on, with absolute regularity. It is still a matter for investigation as to why and how this altogether exceptional alternating reversal of the heart's action is brought about.

It is a curious fact in illustration of the essential character of the heart and its beat that "hearts" are produced in some animals by dilatation of the lymph-vessels -a system of delicate vessels, difficult to see, which take up the colourless fluid which the blood-vessels exude into the tissues and return it to the heart. The eel has a pair of these "lymph-hearts" in its tail, and the common frog has a pair near the shoulder-blades and another pair at the hips. These sacs have muscular walls, and pulsate rhythmically like the blood-heart, driving on the lymph fluid through the lymph vessels to join the blood-stream.

The simplest thing in the animal world which can claim the name of a heart-or, at any rate, be compared with that organ-is found in those microscopic animalcules which consist of only a single "cell" or corpuscle of living protoplasm. These animalcules may be compared to a single brick or unit of structure, whereas all other animals consist of thousands, or even millions, of such corpuscles or units aggregated and fitted together as are the bricks and planks of a house. In most of these uni-cellular animalcules you may observe with a 
high-power microscope a little spherical liquid-holding cavity, which slowly enlarges, then bursts at the surface and collapses. After a brief interval it forms again, and again bursts to the exterior. In the "bell-animalcule" -a beautiful active little creature only one-thousandth of an inch in diameter-it may be seen to form, swell, collapse, and re-form as often as twenty times in a minute (see Fig. 4I). Soluble colouring matter taken in by the animalcule with food is excreted by the liquid accumulated in and ejected to the exterior by this spherical chamber. It is called the "pulsating" or "contractile" vacuole, and by its rhythmical pulsating movement of dilatation and collapse presents definite points of similarity to the alternately dilating and contracting hearts of higher animals. The entering flow of liquid here, as in the veins and heart of higher animals, is continuous. The rhythm is due, as is the rhythm of the heart, to the alternation of a brief period of activity or contraction, and a brief period of consequent exhaustion, rest, and repair on the part of living contractile substance. 


\section{XVII}

\section{SLEEP}

$A \mathrm{~N}$ enterprising journalist has recently published A the replies of a number of well-known men to an inquiry as to how many hours' sleep they are in the habit of taking, and what they find to be the best remedy for sleeplessness. Such an inquiry naturally leads on to further thoughts about "Sleep." What a mysterious, yet sweet and lovable thing it is! How strange it is that we all regularly and gladly abandon ourselves to it! How terrible is the state of those who cannot do so! And then one is led to ask, what is it? and why is it? Do all living things sleep for some part of the twenty-four hours? How does it differ from mere resting, and in what does its virtue consist?

Shakespeare has said the most beautiful words that have ever been uttered about sleep, and that because he knew what it was to seek for it in vain-

"Methought I heard a voice cry, 'Sleep no more! Macbeth does murder sleep,' the innocent sleep; Sleep, that knits up the ravell'd sleave of care, The death of each day's life, sore labour's bath, Balm of hurt minds, great Nature's second course, Chief nourisher in life's feast."

And again, when the strenuous life of the great Bolingbroke has at last overtaxed his brain, and he can 
no more find rest and unconsciousness at night, Shakespeare makes him say-

"How many thousand of my poorest subjects Are at this hour asleep! O sleep, O gentle sleep, Nature's soft nurse, how have I frighted thee, That thou no more wilt weigh my eyelids down, And steep my senses in forgetfulness? Why rather, sleep, liest thou in smoky cribs, Upon uneasy pallets stretching thee, And hush'd with buzzing night-flies to thy slumber, Than in the perfum'd chambers of the great, Under the canopies of costly state, And lull'd with sound of sweetest melody?"

Poets have as a rule been too ready to make much of the likeness of sleep and death, whereas there is an absolute difference in their mere appearance. Sleep makes even those who are ill-favoured and coarse look beautiful, imparts to its subjects a graciousness of expression and of colour, and a gentle rhythmic movement, whilst suffusing them as it were with an "aura" of contented trustfulness. These things are far from the cold stillness of pallid death. And this depends upon the fact that in sleep, though many of the activities of the body and mind are checked, and even arrested, there are yet still present the never-ceasing pulse of the heart, the flow of the blood, the intake and output of the breath, and a certain subdued but still active tension of muscles, so that though the body and limbs are relaxed they never assume the aspect of complete mechanical collapse which we see in death. The pupils of the eyes are strongly contracted during sleep, not relaxed and expanded as are those of wide-awake people in the dark. There are some well-known works of art-both painting and sculpture-in which the dead are not truly represented, but are made to retain the 
resistfulness and pose of living men and women; others show true observation in presenting the startling and distinctive flaccidity of the newly dead, which is followed after a few hours by the equally characteristic rigor mortis, or stiffness of the dead. There are many fine studies of sleep by sculptors, but none which to my thinking so delicately and truthfully present its most beautiful and peculiar effects on the muscular "tone" as a work in the Luxembourg Gallery in Paris, called "Le Nid" - a baby of a year old and a little girl of three or four years, asleep side by side on the cushion of a capacious arm-chair. The pose and the details of muscular relaxation differ greatly and characteristically in the two children. One would like to see sleep at different ages and under various conditions of fatigue similarly portrayed, for there is a range and variety of expression in those who sleep, not perhaps as extensive, but as beautiful as that to be found in those who are awake.

All things on the earth may be said (if we use the term in a wide sense) to sleep, for all are affected by the stimulation to activity caused by sunlight and by its cessation during night. It is only of late years that we have come to know of fishes, crabs, worms, and starfishes (many of them without eyes) which live in the depths of the ocean, where no light penetrates and it is always night. The ultimate source of their food is in the upper sunlit layers of water, to which they never penetrate, and from which particles of dead but nutritious matter (the bodies of those who have lived up there) rain down upon them incessantly, like manna on the Israelites. All things accessible to the sun's rays are not equally, nor even similarly, affected by the alternation of day and night, and some not directly at all, but only by the sleeping and waking of 
other things. The food of all living things comes ultimately from plants which, in the presence of sunlight, and only in that presence, and in virtue of its action upon their green leaves, manufacture starch and sugar from the carbonic acid which exists in the air and water around them, whilst they are also thus enabled to take up nitrogen, and so to form their living substance or protoplasm. At night those particles or cells of the living protoplasm of plants which are furnished with transparent green granules, so as to entangle the sunlight, and by its aid feed on carbonic acid, cease this work. They necessarily repose from their labour because the light has gone. This is the simplest example of the sleep of living things. And that here, too, as in higher creatures, sleep is not a merely negative thing - a mere cessation-is shown by the fact that it is at night that other changes go on in the plant. The manufactured food takes effect on the cells or particles nourished by it ; in the night the well-fed, enlarged "cells" in the growing parts of many plants slowly divide each one into two, and each of these again into two, and so on, so as to increase their total number and produce growth and development of the plant. This alternation of activities in day and night occurs even in the invisible microscopic vegetation of pools and streams. Animals-even the most minute, only visible with a strong microscopemove about in search of "bits" of food-in fact, bits of other animals or of plants-and they, too, are, with special exceptions, checked in their search for food by the darkness, for even extremely minute and simple animals are guided in their search by light - that is to say, by a more or less efficient sense of sight. Thus we see that in a general way the sun is truly the ruler of life, and that when he is hidden from us we all become quiescent, a condition which may be rightly considered 
as the elementary form-the simplest equivalent of the sleep of man. The quiescence which falls on the earth with the setting of the sun has, however, become the opportunity of two different classes of living things to seize an advantage. Beasts of prey, many of them, sleep during the day, and steal forth at night on velvet foot to pounce on the slumbering animals which are their necessary food. Another group of timid animals, moths and small beasts like mice, hedgehogs, and lemurs, find their safety in the dark, and only then venture forth. Even so, the moths are met by special nocturnal enemies, the bats. So that the primitive arrangement is complicated by a wakefulness, exchanging day for night.

It is natural to apply the word "sleep" to the state of profound repose which other living things appear to enter upon at night, so far as we can judge by changes of activity and attitude_-although it must be remembered that the sleep of man is what we really indicate by that word, and that it is difficult to trace anything beyond a superficial similarity between man's sleep and the repose or quiescence following upon activity in other living things-excepting those which by their structure and the working of their mechanism are obviously comparable to man, such as beasts, birds, reptiles, and fishes. The "sleep of plants" is the term applied to the closing of the flower, the drooping of the flower-head and of the leaves of many of the common flowering plants, which occurs at sunset or during the later hours of sunlight. But it seems that this is not really comparable to man's sleep. The closing of the flower appears to be a protection of its perfume from useless evaporation during the darkness, and the drooping a device to avoid the settlement of dew and the injurious action of cold. Living things always furnish us with examples of adaptations resisting the general law-and as there are 
moths which fly by night, so also there are flowers which remain closed by day and open at night to attract these moths, by whom their pollen is carried and their fertilisation effected. The tobacco-plants of our gardens are examples of these night-opening flowers, which attract the nocturnal moths by their heavy perfume, and there are many others.

The movements of plants are much more definite and varied than one is apt to suppose. Leaves and flowers turn to or away from the sun, or to or from the position which will favour a deposit of moisture; or, again, their tendrils will explore and seize upon supports, enabling them to secure a hold, and so to climb. The sensitive plant exhibits rapid drooping movements of its leaflets and leaf-stalks when touched or subjected to vibration.

An allied plant which shows slower but definite movement of its leaflets has been supposed to furnish thereby prophetic indications of the weather, and even to foretell earthquakes. This plant is the Abrus precatorius, the seeds of which are called crab's-eyes, and are used in India by jewellers and druggists as weights - averaging a little less than two grains. They are harmless when eaten, but contain a poison called abrine, which causes them rapidly to produce fatal results when introduced beneath the skin. Under the name "jequerity" they were introduced into this country in I 882 for the treatment of ophthalmia. This is the plant which was celebrated, about twenty years ago, as the earthquake plant or weather plant, owing to the statements of an Austrian naturalist as to its marvellous powers of prophecy by the movement of its leaflets-statements which were carefully examined by botanists at Kew Gardens at the time and shown to be devoid of justification. Earth tremors, like other vibrations, cause the leaflets to move and 
change their pose as they may cause animals to utter cries of alarm, but the movements of the leaflets have no more prophetic character than have those of the delicate pendulums, called seismographs, by which it is now usual to register the constantly occurring slight vibrations of the earth's crust.

That beasts and birds enjoy a nocturnal sleep similar to that of man, which is occasionally - like his sleeptransferred from night to daytime, is a matter of common knowledge. These animals, like man, lower the eyelids and adopt a position of ease when sleeping, even though they often remain poised on their legs. The question has been raised as to whether fishes sleep, since they have no eyelids and remain when at rest poised in the water. We made some inquiries on this subject in the laboratory of the Marine Biological Association at Plymouth some years ago, and came to the conclusion, from the observation of various marine fishes in the aquarium there, that fishes do sleep at night. They come to rest on the bottom of the tanks, and are not so quickly responsive to a touch or intrusion of any kind as they are in the daytime. It is probable that this condition of repose is more definitely marked in some kinds of fishes than in others, but in all shallow-water marine organisms the absence of light produces a corresponding period of quiescence. That there is a good deal more than this involved in the sleep of the higher animals and of man will be apparent when we come to study it more closely.

The sleep of man, and of animals which have, like man, a large and well-developed nervous system-has for its salient feature the cessation or extreme lowering of the "psychical" activity of the brain. When sleep is at its height external agents (such as a touch, a sound, a flash of light) which in the waking state set up through 
the nerves of the organs of the senses complex changes in the brain, no longer do so. They not only fail to excite consciousness and to leave their mark on the memory, but they do not produce even a simple unconscious response. Yet if they are of a sufficient degree of violence (varying according to the depth of the sleep), they do reach the brain, and thus "awake" the sleeper. Corresponding to the absence of receptive activity of the brain in sleep is the absence of outgoing impulses from that organ; there is no such control of the muscles as in the waking state, the head nods, the eyelids droop, and the muscular action by which the erect posture is maintained is in abeyance, although in a greatly lessened degree some amount of muscular tone is unconsciously retained.

The passage from the waking state to that of deep sleep is not sudden but graduated, and so is the process of awakening. In the intermediate condition, either before or after deep sleep (often only a minute or two in duration) the brain can still receive, more or less confusedly, impressions from the exterior through the organs of sense, and it is in this way that "dreams" are set going, and may be afterwards either forgotten or remembered. In full sleep the mind is a blank. As a rule healthy sleep becomes gradually more complete in the first hour, and then very slowly less profound. But there are not any sufficient observations on the "quality" of sleep after short or long duration. In sleep it is not only the brain which is at rest: the whole body shares in the condition. The pulse and breathing are slower, the digestive organs and the bladder are more or less at rest. Both the intake of oxygen into the lungs and the expiration of carbonic acid are lessened. The chemical changes within the body are lessened though still proceeding, and as a consequence the temperature is lowered. 
It is curious how incomplete at present is the physiologist's knowledge of both the actual condition of the brain in sleep and of the immediate causes which produce that condition. It is probably true (though it is disputed) that the brain becomes pale during sleep, owing to a contraction of the blood vessels, and that the inactivity of the brain arises from this condition. But it is not obvious what determines the contraction of these vessels at the definitely recurring period of sleep. It is probable that the nervous tissue of the brain is, as are the muscles of the body, poisoned or choked (as it were) by the chemical products of the day's activity, and so readily cease to be active until the injurious products have had time to be carried away by the blood stream. Muscular substance undoubtedly is affected in this way, and that great muscle the heart, though never resting for a lengthened period, rests after each pulse or contraction, and recovers itself in the brief interval.

It is also probable that the exhaustion by the day's activity of the oxygen stored up in the various tissues of the body produces a condition of quiescence whilst the store is replenished. Stimulation of the nerves through the sense-organs of sight, hearing, and touch will prevent or retard this natural quiescence, and the cessation of that stimulation is favoured first of all by the darkness of night and by the closing of the eyelid, as well as by the removal of clothes which more or less irritate the skin; also by the would-be sleeper taking up a position of perfect rest, and by the exercise of his will, withdrawing his brain as much as possible from all external influences. The would-be sleeper also controls, when possible, that internal stimulation of the brain which we call attention. It is the failure (owing to unhealthy conditions) to control the latter which leads to the most serious kind of sleeplessness, when the brain gets for hours out of re- 
straint and works incessantly like an independent existence. The disturbance of the nervous system set up by irritation of the digestive organs, whether accompanied by pain or not, is an independent cause of sleeplessness which often co-operates with the first, and is (through the mechanism of the nerves) often set going (though it may arise independently) by an unhealthy excess in the excitement of the brain's activity. There is no panacea for sleeplessness; the only thing to do is to consult a first-rate physician, and strictly follow his advice.

There are many irregularities and abnormal manifestations of sleep. There is the sleep which is induced by drugs such as opium, chloral, and alcohol, and that induced by chloroform, ether, and nitric gas. There is the heavy sleep accompanied by stertorous breathing, and there is the unconscious condition called "coma." Then there is the prolonged sleeping called "trance," of which that of the Sleeping Beauty, only to be broken by a kiss, is an example. It is not possible, in the present state of knowledge, to give an adequate account and explanation of the condition of the brain in these different forms of sleep, nor of the causes which induce that condition. One of the most interesting forms of sleep is the condition called "somnambulism," or sleep-walking, in which part only of the brain is asleep, and other parts connected with various degrees of mental activity are in waking order. Sleep-walking is a condition which occurs spontaneously. On the other hand, "hypnotism" is the name for a peculiar kind of sleep produced intentionally by an operator on a patient by certain treatment and direction. In one of the stages of artificially induced hypnotic or " mesmeric" sleep-called the somnambulic stage -only so much of the brain is asleep as is concerned with conscious memory. The brain receives stimulation through the sense-organs, and the patient has the eyes 
open and appears to be awake. In this state he is peculiarly open to suggestion by words, which can be made to set up the most extraordinary illusions and consequent behaviour. On "waking" the patient has no memory of what has occurred, though a suggestion received in the somnambulic stage may persist in the unconscious memory, and cause conduct on the part of the patient (many hours after the brief hypnotic sleep has passed) which is entirely inexplicable by the patient himself or by those who are not aware of the fact that he had received a "suggestion" or "direction" when in the hypnotised state. The senses of smell, hearing, and touch are often abnormally acute in a hypnotised patient, but there is no evidence to show that the brain of such a person can be influenced or "communicated with" excepting through the ordinary channels of the sense-organs. "Daydreaming" and "reverie" are conditions resembling the hypnotic sleep. The brain of each of us is constantly doing much of its work in a state of partial hypnotism, and the term "unconscious cerebration" has been used to describe it. A most interesting and difficult chapter of the study of mental disease belongs here.

The prolonged sleep of some animals in the winter, called "hibernation," seems to be closely similar to ordinary sleep, but is set up by the depressing action of continuous cold instead of by the daily recurring quiescence of night and by the exhaustion due to the day's activity. Many animals - such as the marmot and dormouse, the frog and the snail-exhibit this winter sleep. It has been found by experiment that even in midsummer the dormouse can be made to "hibernate," by exposing it artificially to a low temperature, and hibernating animals can be roused from their long sleep by bringing them into warmth. During the winter sleep hibernating animals take no food, the pulse is 
slowed down, and the body temperature falls. The scattered fat of the body, and fatty matter and other material stored in special structures called "hibernating glands," are oxidised and slowly consumed during this period, which may last for three or even four months. The animal on waking is often in a very emaciated condition.

It is undoubtedly the case that the human natives of high latitudes (such as the Norwegians), where there is no night in full summer, and where there is prolonged darkness in winter, have acquired the habit of keeping awake for many days in succession in summer, whilst making up for the loss of sleep by excessive indulgence in it during the winter. It is by no means clear how far man is capable of resisting the demand for recurrent daily sleep without injury to health. Undoubtedly many men are compelled by their avocations to sleep by day and wake by night. The length and duration of "spells of sleep" and the power to sleep little or not at all at one season, and almost uninterruptedly at another, without injury to health, are matters of habit, occupation, and circumstance. We have no ground for saying that every man "ought" to sleep eight hours or more per diem, or, on the contrary, for insisting that he should only sleep five or less. All depends on what he is doing when he is awake, and what other people are doing (so as to disburb him) when he is asleep; and we do not even know whether ten or twelve hours' sleep would injure a man, were he able to take it, nor can we suggest how it would injure him supposing it did not interfere with his feeding and exercise.

As to quantities of sleep, there is the curious fact that the amount habitually taken in the civilised communities of this part of the world differs at different ages. Babies sleep a good part of the twenty-four hours, and prob- 
ably schoolboys and schoolgirls (under our present conditions of life and work) ought to be given ten hours or more. Whilst adult men sleep from six to eight or nine hours, it is a curious fact that old people-not very old people, but those of sixty-five or thereabouts-often find themselves unable to sleep more than four hours at night, and take an hour or two in the daytime to make up for the deficiency. I remember hearing Mr. Darwin state this as to himself to his physician, Sir Andrew Clarke, who said it was very usual at his age, and difficult to explain, since at a greater age, when a man is called "very old," a more or less continuous somnolent condition sets in. The father of a great judicial dignitary of these days, himself a barrister in large practice, when he was sixty years old would snatch fifteen or twenty minutes' sleep at any and every opportunity throughout the day, even at the midday meal sometimes, so as altogether to disconcert those who were with him, and he told me that he never slept more than four hours at night, but got up and commenced work at four in the morning. The cessation in early old age of the desire for more than half the amount of sleep taken by younger men suggests that the regulating cause of the number of hours which are needed for sleep may be simply and directly the actual amount of work done by body and mind. This imperceptibly becomes less as men grow older, and so less recuperative sleep is necessary, though what work they do may be more effective and better adjusted to its purpose when they have arrived at the condition which is called "old age."

We have seen that sleep in its widest sense comprises the simple condition of quiescence brought about in even the minutest living things by the recurring night, as well as the strangely elaborated varieties of cessation of activity in the whole or parts of the brain of man 
and of his body. Some of these cessations of activity naturally and spontaneously occur in unsophisticated mankind, when darkness falls on the earth at each succeeding evening. And it is hardly possible to doubt that a tendency to periodic sleep has become fixed in the substance of living things by the alternation of night and day -as well as in some cases by the change of the seasons.

I must conclude these notes about sleep by relating a very curious case of sleep, resembling the winter-sleep of higher animals, on the part of a snail. This was the case of a desert snail from Egypt, which was withdrawn into its shell, the mouth of the shell being closed with a glistening film secreted by the snail, as is usual with snails in this country in winter when they sleep. The desert snail in question was affixed to a tablet of wood in a glass case in the natural history department of the British Museum on March 25, I 846. On March 7, I 850 , that is four years afterwards, it was noticed by a visitor looking at the case that the snail had emerged from his shell and discoloured the paper around, but had again retired. So the officials unlocked the case and removed the snail from the tablet and placed him in tepid water. He rapidly and completely recovered, crawled about as a wide-awake snail should, and sat for his portrait. This may be regarded as an instance of unusually long sleep, natural to this species of snail, and related probably to the frequently prolonged dryness of the snail's surroundings.

We are led by such a case as this on to what are called examples of "suspended animation." Wheelanimalcules, and some other minute creatures which are found living in tiny pools of water, on the bark of trees, and in the hollows of leaves, naturally dry up when the water evaporates. You may dry them yourself in a watchglass; they appear as nothing more than shapeless 
dust particles mixed with the dried mud of a drop of dirty water. They may be kept in this state for months - even years. I do not know that any limit has been ascertained. But when you add pure rain-water to the dust in the watchglass, it softens, and in less than an hour the little wheel-animalcules have softened too, and expanded into life, swimming about whilst the delicate spikes on their "wheels" vibrate regularly as though they had never ceased to do so, and as though the animalcules had not for years been dried-up little mummies.

Of course, the term "suspended animation" has been applied in earlier times to the often exaggerated stories of "trance" and deathlike sleep in human beings. But it is now with more justice applied to these instances of dried animalcules which return to life when wetted, and to similar cases of prolonged retention of vitality by seeds, since it would appear that in these dried animalcules life really is actually and totally suspended, although the mechanism is there which resumes its life when the necessary moisture is supplied. In cases of trance in man and hibernation in animals, the heart is still very slowly and feebly beating, and the breathing is still-almost imperceptibly - at work. The chemical changes are still very slowly and gently proceeding. The buried Indian wizard, and the snail, and the Sleeping Beauty are moist, and chemically active, though feebly so; life is not absolutely suspended. But in the dried animalcule (though complete chemical desiccation is not effected), the removal of the water from the body actually arrests the changes which we call life, just as a needle may arrest the balance-wheel of a watch. Supply the water, or remove the needle, and life ceases to be suspended; it goes on once more (as one of the rules of Bridge ambiguously enacts) "as though no mistake had been made." 


\section{XVIII}

\section{THE UNIVERSAL STRUCTURE OF LIVING THINGS}

WITHOUT doubt, the greatest and most important statement which can be made about living things is that they are either separate minute particles of living matter or (more commonly) are built up by thousands of such minute particles which have in each individual animal and plant originated from a single such particle (the fertilised germ), by its division into two, and the subsequent division of these two each into two, and of the four so produced each into two-and so on, until by repeated division into two, millions of corpuscles, hanging together as one mass, are the result.

The particles of living matter are spoken of as "cells" for a very curious reason, to which I will revert. The living matter is called "protoplasm" (primitive or fundamental slime). A "cell" in the language of microscopists means a corpuscle or more or less rounded or irregularly shaped particle of protoplasm. Cells commonly vary in size from $\frac{1}{3000}$ th to $\frac{1}{200}$ th of an inch in breadth, and may be much larger. Protoplasm - the living substance of "cells" - is a slimy body, almost liquid, but yet tenacious. It is transparent, but clouded by fine granules, and can often be seen with a very high power of the microscope to consist of more and of less 
liquid matter, intermixed like an emulsion. It often has within it large cavities filled with liquid, and also often
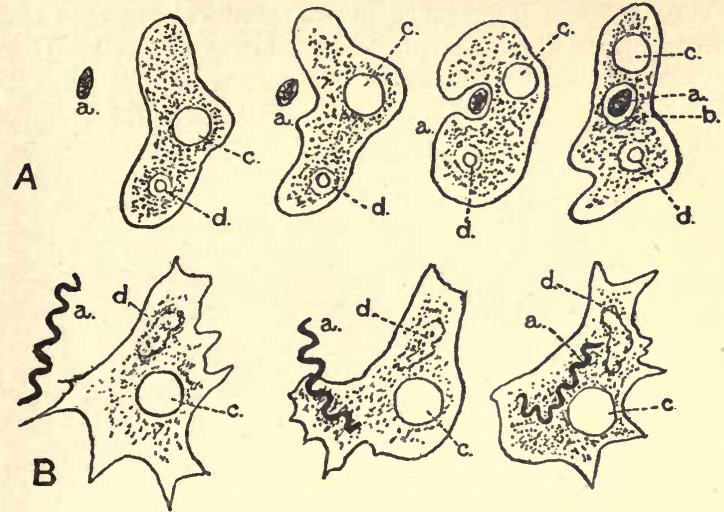

FIG. 36.-Simple "cells," consisting of naked protoplasm, changing shape and taking in solid food particles. A, is a series of four successive changes of shape of a fresh-water animalcule, the proteus or amœba; $\mathrm{B}$, is a similar series of three views of a separate creeping kind of corpuscle found in the blood and lymph-spaces of animals, and called a "phagocyte." It is also said to be "amœboid," from its resemblance to the amœba or proteus-animalcule. B, is from the blood of the guinea-pig. It is not a parasite, but one of the various kinds of cells which build up the animal body, and are derived from the single original egg-cell (see Fig. 31) by continued division. The three drawings show three changes of shape occurring in the same "phagocyte" in a few minutes. It is engulphing a fever-producing blood-parasite, a spirillum, marked $a$, into its soft, slimy protoplasm, to be there digested and destroyed. In the same way the amœba, $A$, is seen in four stages of engulphing the vegetable particle, $a$. In the fourth figure the letter $b$ points to water taken into the amœba's protoplasm with the food-particle $a$. In all the figures, c points to the "vacuole" or liquid-holding cavity, which bursts and re-forms in $\mathrm{A}$; the letter $d$ points to the cell-nucleus.

oil drops; in other cases hard concretions or coarse granules. But apart from other things, the protoplasm 
of a "cell" always contains within it a special, firmer, and denser part, enclosed in an enveloping coat or skin. This dense body is the "nucleus," or kernel, and is of the very greatest importance in the chemical changes and movements which constitute the life of the cell. It is usually spherical, and in the living state often looks clear and bright. All cells, whether they are found building

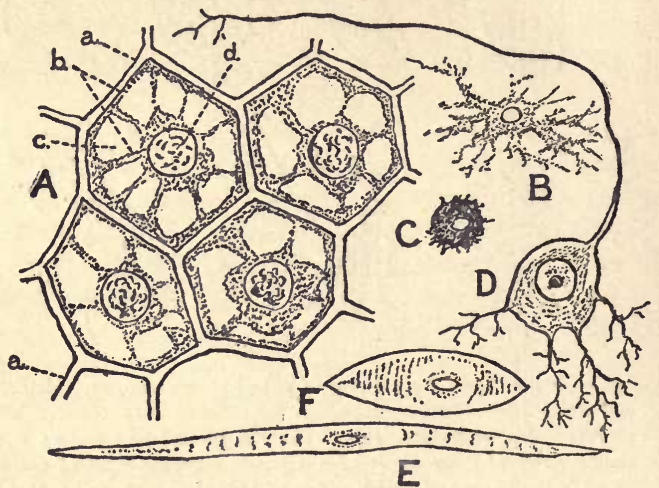

FIG. 37.-A, cells forming soft vegetable tissue ; $a$, cell-wall ; $b$, protoplasm ; $c$, liquid-holding cavity in the protoplasm ; $d$, the nucleus. $\mathrm{B}$, a pigment-cell from the frog's skin, expanded. C, the same cell contracted. D, a nerve-cell : observe the nucleus. E, a musclecell stretched. F, the same contracted : observe the nucleus.

up the bodies of plants and animals like so many living bricks, or living freely and singly as animalcules, have the essential structure just described-a semi-liquid yet tenacious material enclosing a globular firmer body, the nucleus.

How did these viscous nucleated corpuscles come to be called "cells"? It was in this wise. At the end of the seventeenth century Dr. Robert Hook, secretary of 
the Royal Society, published a beautiful book of folio size, entitled Micrographia. In this he pictured various minute insects and various natural products as seen under his microscope. Among the objects figured and described was a piece of cork (Fig. 38). Hook showed that it was built up of a number of empty, air-holding, box-like chambers, less than the hundredth of an inch in length, and these he called "cells," comparing them to the "cells" of the bee's honeycomb. Later observers

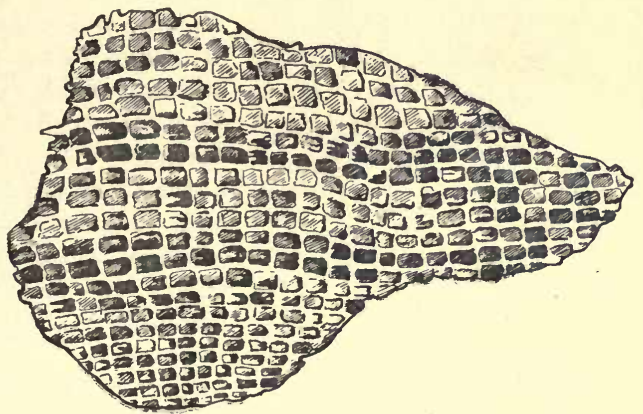

Frg. 38. - Copy of part of Robert Hook's drawing of a magnified piece of cork, showing the "cells" so named by him in 1665 .

found that this "cellular" structure was very common in plants-but it was not until more than a hundred years later that it was observed that the "cells" which build up the soft stems and leaves of plants are not empty or merely air-holding, but contain a liquid or viscid matter. Robert Browne, a great botanist, who lived within the memory of some of our older naturalists, first observed and described the " nucleus," or kernel, within the cells of some lily-like plants, and gave it that name (Fig $37 \mathrm{~A}, d$ ). About the thirties of last century, by aid of improved 
microscopes, a structure like that of the vegetable "cell" and its " nucleus" was discovered in some animal materials, or "tissues," as they are termed-for instance, in cartilage (Fig. 39). The word "tissue" is applied to each of the various layers and masses, such as epiderm, fibrous tissue, muscle, nerve, cartilage, bone, which can be distinguished in an animal body and separated from one another, just as we may separate the "tissues" of a man's clothes - the leathern, woollen, silken, cotton,

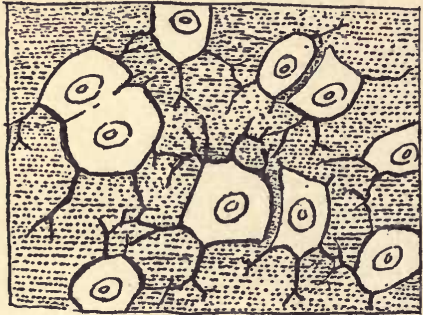

FIG. 39.-A piece of cartilage, showing the cells which have formed it embedded in the (shaded) firm substance, and connected to one another by branching processes of protoplasm.

linen : the cords, laces, threads, and pads or stuffing. The full meaning of this existence of "cells" or "cellular" structure in the tissue of plants and animals only gradually became evident. A very remarkable discoverer, Professor Schwann, of Liège (with whom when he was an old man I spent an afternoon a great many years ago), was the first to grasp the great facts and to put forward what has been ever since called "the cell theory" of animal and vegetable structure and life.

Schwann, in 1836 , showed that the important thing about a "cell" is not the box or cell-wall so much as the viscid contents and the nucleus. But the name "cell" was (strangely enough) retained for the contents, even when the box-like chamber was absent-much as we speak ot "a bottle of wine," meaning the contents of the bottle, and not the glass vessel holding it. It was 
shown that the box-like case or cell-wall (the original "cell" of Hook) is actually formed by the living nucleated plasm or viscid matter within it, just as a snail forms its shell, by the separation or "secretion" of a dead, firm, chemical deposit on its living surface. Schwann showed that all-not merely special exceptional instances, but allthe tissues of plants and of animals are built up by nucleated cells, the cell-wall being often not hard and box-like, but soft, gelatinous, irregular in shape, and sometimes very thin, sometimes very thick. Every living cell is thus surrounded by the chemical products of its own activity, or may deposit those products within itself as in the goblet-cell and the fat cell seen
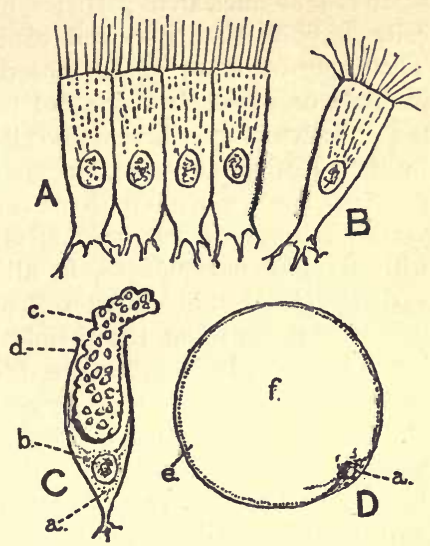

FIG. 40.-Three kinds of cells, magnified a thousand times linear. A, a row of ciliabearing cells. B, a single detached ciliated cell : observe the nucleus in each cell. C, a goblet-cell, from a mucous surface, producing $c$, a slimy secretion ; $d$, the wall of the cell ; $b$, the nucleus; $a$, the protoplasm in which the secretion $c$ was accumulated until it burst out at the free end of the cell. D, a fat-cell ; $a$, the nucleus surrounded by protoplasm ; $\ell$, the thin layer of protoplasm enveloping the great oil drop $f$, which has formed within it. in Fig. 40, C and D, and these products differ in different tissues. The cells of a tissue, using the word to mean the soft nucleated particles or corpuscles of protoplasm or "cell-substance," must be regarded as the microscopic living "weavers" 
or makers of the tissue. The cells in one tissue may form a honeycomb of boxes; in another a jelly-like mass or a fibrous network, with the cell-substance scattered as nucleated particles in it (Fig. 39). Or the cells may be elongated and contractile (Fig. 37, E, F). They may be more or less fused with one another, as in flesh or muscular fibre; but we can always recognise the presence of the individual cells under the microscope by their distinct and separate "nuclei."

Schwann's most important conclusion from this universal presence of soft corpuscles of cell-substance, each with its globular nucleus, in all the tissues and most varied parts of animals as well as plants, was that the life of a living thing, the chemical and physical changes which go on in it from birth to death, consist in chemical and physical changes in each of these microscopic, nucleated bodies, and that the life of the whole animal or plant is the sum of the lives of these microscopic units. If we wish to know more about the real nature of the growth and activities of living things, said Schwann, we must thoroughly study and ascertain the chemical and physical changes, and the properties of the cell-substance in all the different varieties of tissue. That is the celebrated "cell-theory" of Schwann. And this examination of, and experiment with, the cells of all kinds of tissues of plants and animals has been going on ever since Schwann made his historic statement more than seventy years ago. The branch of science called "histology" is the outcome of that study.

Microscopes have been immensely improved since Schwann wrote, first in England by the father of the present Lord Lister, then later in Germany by Abbé and Zeiss, of Jena. A variety of methods have been devised for making the "cells" in thick, solid tissues visible. Very thin sections-thin enough to be trans- 
parent-were at first cut from the fresh tissues, and examined by transmitted light. This did very well in a rough way, but better results were obtained by hardening the tissues in alcohol or chromic acid, when wonderfully fine sections could be cut and rendered translucent by soaking in varnish, in which they were preserved for study with the microscope, between two plates of glass. The sections were stained with various dyes, such as carmine, log-wood, the aniline dyes, etc., and it was found that the nuclei of the cells and the granules and fibres both in the minute cells and in the surrounding substance manufactured by them, could be distinguished more clearly by means of their differing affinity for the dyes. And whilst endless section-cutting and staining and careful drawing and record of the structure discovered, was proceeding in hundreds of laboratories-other observers especially devoted themselves to the difficult task of seeing the cell-substance or protoplasm and its nucleus under the highest power of the microscope, whilst still alive! It would seem a hopeless task to examine with a high-power microscope the cells (less than a thousandth of an inch broad) inside the solid stem or leaves of a plant or of an animal's body without killing the plant or animal and the cells of which they consist. As most of my readers know, the front lens (or "glass") of a high-power microscope has to be brought very close indeed to any object in order to bring it into focus-as near as the one twenty-fifth of an inch. Then the object examined must be very small and transparent, in order that the light may pass through it, as through the slide-picture in a magic lantern, and so form a clear, well-defined picture in the focus of the microscope, where the eye receives it.

Fortunately, there are some facts about living cells or corpuscles of protoplasm which enable us to examine 
living cells, in spite of these difficulties. In the first place, there are a whole host of minute animals and plants_-of many different kinds-which consist of only one cell or nucleated corpuscle of protoplasm (Fig. $36 \mathrm{~A})$; they are transparent, abound in fresh water and sea water, and can be searched for with the microscope in a drop of water placed on a flat glass plate and covered with a specially thin glass slip. Many of these have been studied for hours and even days-continuously, and the remarkable internal currents and movements of their viscid "protoplasm," its changes of shape, its feeding and growth, and the details of the process of division into two - by which it multiplies - have been ascertained, as well as the action upon it of light, heat, electricity, and mechanical shock, and of all sorts of chemical substances, carefully introduced beneath the cover-glass. A second fact of great importance is that the "cells" or protoplasmic corpuscles, which build up a complex plant or animal, do not die at once when the plant or animal "dies," that is to say, the animal or plant may be "killed" and fine bits of transparent tissue removed from it and placed beneath the microscope, where, with proper care, the cells may be kept alive for some time. The hairs of many plants are strings of transparent "cells," or boxes, containing living, streaming, active protoplasm. These hairs can be cut off, and the cells will remain alive for a long time whilst they are under the microscope (see Fig. 15 bis). The transparent wall of the eye-called the cornea-can be removed from a frog after it has been killed, and the still-living cells in the delicate glasslike tissue can be studied with the highest powers of the microscope, and give evidence of their life by their movements and other changes. Most convenient and important for this study is the blood-for there the cells are loose, floating in the liquid. The cells in a 
minute drop of human blood can be kept alive for hours, if the glass slide is kept warm, as it easily can be, and I have seen the cells in a drop of frog's blood (skilfully treated) still alive, and exhibiting active movements, a fortnight after the frog, from which the drop of blood came, was dead and buried. These floating, moving cells of the blood are the "phagocytes," which engulf and digest disease germs and other particles (Fig. $36 \mathrm{~B}$ ). Other more numerous cells of the blood are the oxygencarriers, or red corpuscles, which do not show any movements or changes of an active kind whilst alive. 


\section{$\mathrm{X} I \mathrm{X}$}

\section{PROTOPLASM, LIFE AND DEATH}

THE result of the study of living cell-substance, or protoplasm, is to show that every cell has an individual life, and often makes this manifest by its movement, change of shape, and internal currents of granules, as well as by the special chemical substances it produces and consumes. All depend for their activity upon the presence of free oxygen; all are killed by heat far less than that of boiling water; they continually imbibe water charged with the chemical substances which nourish them and cause them to grow in bulk and to divide into two; and they manufacture various chemical bodies in the protoplasm and emit heat, electrical discharges, and sometimes light. Some or other of them, in fact, do in their small microscopic way all that the complex, big animal or plant, of which they are constituents, is seen to do. The cells of the liver manufacture the bile, those of the salivary glands the saliva, and those of the intestinal wall a mucous fluid, and squeeze out or eject those products into the adjacent ducts (see Fig. $40 \mathrm{C}$ ). Other cells lay down (as cell-wall or coating) fibrous and hard substances which form the skeleton; others become converted into horn and are shed from the surface of the skin in man as "scurf"; others form the great contractile masses called muscles. One lot are told off to control 
the other cells by something resembling a system of electrical wires and batteries-these are the nerve-cells (Fig. 37 D), with their fine, thread-like branches, the nerve-fibres, which are long enough to permeate every part of the body and place it in connection with the nerve-cells in the great centres called brain, spinal cord, and ganglia.

At one time it was thought that the cells in the tissues of plants and animals could originate de novo by a sort of precipitation of liquid matter. But it is now known that every cell has originated by the division of a pre-existing cell into two, the nucleus of the mother cell first dividing and then the rest of the cell. "Every cell originates by the fission of a preceding cell" is the law, and to that is added, "Every individual organism, plant or animal, itself originates from a single cell, the fertilised germ-cell." These are two laws of fundamental importance in the study of living things. They are true of man as well as of the smallest worm; of the biggest tree as well as of the most insignificant moss or water-weed. When the fertilised egg-cell divides, and its progeny keep on dividing and growing in bulk by the conversion of nutriment into protoplasm, the dividing cells do not necessarily become entirely nipped off from one another. In large tracts of cells (or tissues) we often find that the neighbouring cells are connected to one another by excessively fine filaments of protoplasm. Only twenty years ago it was supposed, whilst the neighbouring cells were thus connected as a rule in animals, as well as being often connected to the finest nerve-filaments, yet that in plants the firm, box-like cases which surround the protoplasmand when seen dried and empty by Robert Hook led him to introduce the word "cell" to describe them-form completely shut cases, so that the living protoplasm of each plant-cell is entirely cut off from its neighbour. 
This has now been found by improved methods of microscopic examination to be a mistake. The cell-wall in a great many plants, though so firm and cleanly cut in appearance, is yet perforated by fine threads of the cell protoplasm, so that each cell is in living communication with its neighbour. Thus, in plants as well as in animals, the individual cell-units form a more or less continuous whole of living matter, separated by dead, inert cellwalls and products of cell activity; but, nevertheless, connected in definite tracts and regions to one another by continuity of the living matter in the form of excessively fine threads.

Those animals and plants which are built up of many cells of many varieties - that is to say, all but the microscopic unicellular kinds-may be considered as composite organisms-cell-states or communities in which the individual cells, all derived from one original mother-cell, are the citizens, living in groups and habitations (tissues), having their different occupations and capacities, carrying on distinct operations and working together for the common good, the "life," as we call it, of the individual plant or animal which they constitute. This comparison should serve merely as an illustration of the individual character and co-ordinated activity of the cells of a manycelled plant or animal. It must not be forgotten that the separate cells are all derived by binary division from the original germ-cell, that they have not come into juxtaposition from distinct sources, but often are held together by threads of their living material, which remain after the process of division of one cell into two.

Protoplasm has been called "the physical basis of life." Since the activities to which we give the name "life" reside in protoplasm, and are chemical and physical activities like those of other bodies, even though more subtle and complicated-we are justified in regard- 
ing protoplasm as the substance in us and other organisms which "lives." Death consists in the destruction-the chemical undoing or decomposition of protoplasm. ${ }^{1}$ In simple microscopic unicellular animals and plants, this is obvious - so long as the protoplasm retains its chemical structure it is not "dead." Thus, it is possible with many small simple organisms - such as animalcules and the seeds of plants - to dry them, and to expose them to extreme cold, and to deprive them (by aid of a vacuum pump) of all access of free oxygen or other gases. All chemical change is thus necessarily arrested. But the atomic structure of the chemical molecules in the protoplasm is not destroyed. Sir James Dewar, M. Becquerel, and others have shown this by most carefully conducted experiments. Seeds of clover, mustard, and wheat so treated do not "die"; the mechanism remains intact, and when, after many weeks, the seeds are moistened, warmed, and admitted to contact with the atmosphere, the mechanism again begins to work, the protoplasm resumes its activity, the seed "sprouts." Similarly Dewar has shown that bacteria are not killed by extreme cold, the temperature of liquid hydrogen. When thus frozen they remain inert-but are even in this condition liable to be "killed" by exposure to the blue and ultra-blue rays of sunlight! Life was defined by Herbert Spencer as "the 'continuous' adjustment of internal to external relations,"

1 Protoplasm is not a single chemical compound; it is the name given to the soft, slimy substance of cells, and contains many chemical compounds-proteids, fats, and others; some on the way to assume greater chemical complexity; others in process of destruction. The critical highest chemical body concealed in protoplasm has no generally recognised name. It is a proteid-like body, consisting chiefly of carbon, oxygen, hydrogen, and nitrogen, with some saline constituents. This is the real ultimate "living matter," and I suggested in the Encyclopedia Britannica (article Protozoa) in 1886 that it should be called "plasmogen." 
and this implied that what is called "suspended animation" was not really a possible thing, but that there could only be an apparent or approximate suspension. On the contrary, it seems that just as we may stop a watch by holding back the balance-wheel with a needle, and yet not "kill" the watch-for it will resume its movement as soon as the needle is removed-so the changes of the chemical molecules of protoplasm can be arrested, but if the chemical "structure" is uninjured the mechanism of protoplasm can resume its activity when the arresting causes are removed. The inactive, unchanging protoplasm is not "dead," it has not been "killed" so long as its mechanism is intact.

On the other hand, it is the fact that this mechanism - the chemical structure of protoplasm-is very easily destroyed. A unicellular organism is chemically destroyed by crushing or disruption, and the consequent admixture of an excess of water with its particles, also by a temperature high enough to cause pain if applied to our skin, but yet much below that of boiling water, also by strong sun-light, and by very many varieties of chemical substances, especially acids, even when very much diluted. Complex animals and plants are liable to have the protoplasm of essential and important cells of the body destroyed, whereupon the destruction or death of the other cells, not involved in the original trouble, frequently and as a rule results. The protoplasm of the cells of a complex animal is dependent on the proper activity of many other cells besides those of its own tissue or locality in the body. If the protoplasm of certain nerve-cells or of blood-cells or of digestive-cells is poisoned or injured or chemically upset, other cells lose as a consequencenot at once but after a short interval-their necessary chemical food, their oxygen, their accustomed temperature, and so bit by bit the great "body"-the complex 
organism-ceases to live, that is to say, its protoplasm undergoes step by step and bit by bit irrevocable chemical change or breaking down.

When a man enters upon that condition which we call "death," the general muscular movements first cease, then the movements of respiration (so that a mirror held to the mouth was used to test the coming and going of the breath, and the absence of a film of moisture on the mirror's surface was held to be a proof of death), then the movement of the heart, which is followed by the awful pallor of the bloodless face and lips, and the chilling of the whole body, no longer warmed by the blood-stream. But for long after these changes have occurred the protoplasm of the cells in many parts is not injured. The beard of a corpse will grow after all the great arrests of movement above noted have been established for hours. In cold-blooded animals, such as the frog, the protoplasm of the muscles is still uninjured many hours after decapitation, and they can be stimulated and made to contract. Death, in fact, only occurs in the tissues of a multicellular animal, as their protoplasm becomes chemically destroyed by injurious temperature, poisonous accumulations, or active bacterial germs, which become predominant owing to the stoppage of the great mechanisms of breathing, circulation, and nerve control.

Is it, then, necessary to suppose that a something, an essence, a spirit, an intangible existence called "life" or "vitality," or the "anima animans," passes away, or, as it were, evaporates from a thing which was living and is now dead? Assuredly no more than it is necessary to suppose that an essence or thing called "death" takes possession of it when it ceases to carry on the changes which we call "living." It must not be supposed that we regard the unique and truly awe-inspiring processes 
which go on in the protoplasm of living things as something simple, easily understood and accounted for, because we have given up the notion that life is an entity which enters into living things from without and escapes from them at death. The real fact is, that the notion of "spirits," whether of a lower or of a higher kind, supposed to enter into and "affect" various natural objects, including trees, rivers, and mountains, as well as animals and man, does not help us, and only stands in the way of our gaining more complete knowledge of natural processes. When we say that life and even its most tremendous outcome - the mind of man - are to be studied and their gradual development traced as part of the orderly unfolding of natural processes, we are no whit less reverent, in no degree less impressed by the wonder, immensity, and mystery of the universe, than those who, with happy and obstinate adherence to primitive conceptions, think that they can explain things by calling up vital essences and wandering spirits. 


\section{CHEMISTRY AND PROTOPLASM}

W $\mathrm{HEN}$ the chemist examines living cell-substance or protoplasm-as free as possible from dead envelopes and products of its own activity-so as to make out, if he can, what it is chemically, he finds that it consists of the elements carbon, oxygen, hydrogen, and nitrogen, with some sulphur. Phosphorus and some potash, soda and lime in small quantity, are also very usually associated with the elements named. These are combined in the protoplasm so as to form chemical compounds resembling and including white of egg, and are called "proteids." A chemical compound is a very definite and special thing, and when one says so-and-so is a definite chemical compound, one means that it is not a mere "mixture," but is composed of chemical elements (some out of the long list of about eighty indestructible, undecomposable, "simple" bodies_-gases, liquids, metallic and non-metallic solids-recognised by chemists and known as such), peculiarly united to, or "combined" with, one another in definite proportions by weight.

Take, as an example, water. Water is a definite chemical compound, formed by the chemical union of two pure elements, the gases hydrogen and oxygeneighteen ounces of water consist of two ounces of hydrogen and sixteen ounces of oxygen. At a tem- 
perature above that of boiling water the gases, when they unite, contract to form water-vapour, three pints of the uniting gases (consisting of two pints of hydrogen and one of oxygen) forming two pints only of watervapour. This, when it is cooled to a temperature below 2 I 2 deg. Fahr., suddenly contracts to a few thimblefuls of pure liquid water. Neither oxygen nor hydrogen "uncombined" liquefy till far below zero.

A proteid, in the same way, is a chemical combination of the elements already mentioned-carbon, oxygen, hydrogen, nitrogen, and sulphur-but the proportions by volume of these elements to each other are represented by very high figures, not merely by two to one, as in the case of water. It is the carbon in them that makes "proteids" turn black when they are destroyed by burning, and it is the sulphur which causes the smell of rotten eggs. Whilst an ultimate molecule or physical particle of water consists of two atoms of hydrogen and one of oxygen-the molecule of the proteid called "albumen" is built up by seventy-two atoms of carbon, one hundred and twelve atoms of hyrodgen, eighteen atoms of nitrogen, twelve atoms of oxygen, all brought into relation with one atom of sulphur. Probably in some other proteids the number of these atoms must all be multiplied by three. The elaborate "atomic composition" of a molecule of proteid renders it very unstable; it easily falls to pieces, the elements combining, in other and simpler proportions, to form less "delicate" bodies. Living protoplasm consists chiefly of proteids and of compounds which are on the way up, forming step by step more elaborate combinations till they reach the proteid stageand of many others which are degradation products, coming down, as it were, from the giddy heights of the proteid combination. The protoplasm of a cell contains finer and grosser granules, which are these ascending 
and descending substances; it also contains others in solution and invisible - for, like a lump of jelly (such as the cook serves up shaped by a mould and soaked with flavour and colour), protoplasm can soak up either a large or a small quantity of water, and with the water (that is the important point) all sorts of chemical bodies soluble in water. Just as a lump of quivering calves'-foot jelly (which is a chemical compound of a lower grade than proteids, but like them), when placed in a shallow dish of water coloured red by carmine, does not dissolve in the water, but absorbs the water and the carmine, allowing the coloured water and any chemical bodies in solution in it to diffuse into and become physically, though not chemically, a part of its substance, so protoplasm takes up water and the compounds dissolved by it. Just as a "jelly" of water-holding gelatine can give up its water and become hard and horny, so is protoplasm capable of gradually giving up much of its water, and even in some cases of becoming hard and horny, yet able to return, when remoistened, to its active state. Moreover, a "jelly" can be made to "soak up" or take into itself water and let it pass through its substance, so as to wash out from it all soluble matters. In the same way the protoplasm of a living cell is supplied with nourishing and oxygenating fluids which diffuse into it, and is "washed out," purified, and cleansed of waste or effete chemical compounds by the water which first permeates it, and then diffuses out of it into surrounding watery fluids carrying the excess of soluble chemical bodies with it.

Whilst proteids are the compounds of the highest stage of chemical complexity recognised in protoplasm, and appear to form the bulk of its substance, we must carefully avoid the error (which is not uncommon) of supposing that protoplasm is itself a definite chemical 
compound. It is not. Cell-protoplasm includes the nucleus, that denser central body, and is a structure consisting of "proteids" and of many granules and dust-like particles, and of more and of less liquid or watery parts which are less complex in chemical nature than are proteids. Some of the visible granules and invisible liquids present in protoplasm are being built up to the proteid stage of elaboration, whilst some are steps in degradation and decomposition. We have no reason to suppose that the molecules of any proteid known at present to the chemist really are the highest degree of chemical complexity attained to in living protoplasm. Probably there is present a further stage of elaboration, a chemical body even more complex than is "proteid," which is continually attracting the lower chemical compounds to itself and as continually breaking down. This is the ultimate chemical substance of life. It is hidden invisibly in the protoplasm, yet all the chemical changes which go on in the protoplasm of a cell are either leading up to this supreme life-stuff or are leading downwards from it. This ultimate compound, which we suppose to exist but have not demonstrated, has been called "plasmogen." It is this body in which resides the peculiar property of living matter, namely, that of attracting to itself substances containing the socalled "organic" elements-carbon, oxygen, hydrogen, and nitrogen-and of acting on them in such a way that they " nourish" it - that is to say, combine chemically with it to form more "plasmogen."

The intermediate steps leading up to plasmogen and the products arising from its incessant breaking down are formed under the influence of this unique chemical body, and by it alone. Chemists have not yet succeeded in making them; only the less elaborate kinds have been "artificially" constructed without the aid of the 
living plasmogen. To construct plasmogen itself is a task for the chemists of the distant future. In early geological ages plasmogen came into being; it has gone on ever since "nourishing" itself, maintaining itself, growing and spreading over the earth. It is improbable that the conditions which led to its formation have ever recurred. All subsequent plasmogen has been formed by the growth and increase of that first sample of it, which once in a remote period of the earth's history was built up by chemical conditions, which came to an end as soon as they had produced it.

The only process in nature of which we know, which resembles the "building" action of plasmogen, the ultimate molecule of life, buried in the cell's protoplasm, is the selective action of crystals, which draw to themselves from a solution or magma of all sorts of chemical bodies those molecules of a chemical nature identical with their own, and build them up into special and definite crystalline forms. But there is a very wide gap between this process and even the mere assimilation by living matter of the organic elements, so as to raise them from a lower to a higher grade of chemical complexity of combination. And over and above this we have added, in the case of living material, to the mere power of assimilation and growth the almost unthinkable complications and variations of specific form and quality, and yet further of individual form and quality, which are determined by special complications and variations of the plasmogen, that unique compound concealed in the cell-protoplasm.

We cannot at present, if ever, picture to ourselves adequately the mechanism of plasmogen, though the attempt has been, and must be, made. But we can watch its workings closely; we can ascertain the conditions which promote, check, or modify its activity; in 
fact, we can observe its output and experiment on it in a thousand ways, and so get more and more knowledge of it. We are not led to suppose that it is possessed by a demon, nor that in it resides an elsewhere unknown essence. It is enough for us to satisfy ourselves that its qualities, whilst they can be grouped with the chemical and physical qualities of other bodies, so far transcend them in complexity and in immensity of result-the whole creation of plant and animal life-that their appearance constitutes in effect a new departure, a sudden and, to us, unaccountable acquirement. But then we must remember that it is also an unaccountable thing to us that water suddenly becomes ice at a low temperature, and suddenly becomes vapour at a high temperature, even if we are able to imagine the mechanism which necessitates those changes. We cannot "explain" the nature of things. Even though we can classify them and arrange them in order, and more or less satisfactorily guess what their inner mechanism is, we cannot, in our present state of knowledge, trace them in detail to a first beginning. Even though we believe that such a history lies behind us, we ourselves cannot as yet show how exactly every quality and property and form of matter has developed in due order as a matter of necessity during the cooling of the cosmic gas. All we can do is to ascertain, bit by bit, some sequences, some lines of orderly development and interaction, adding thus step by step to our knowledge of what has taken place. 


\section{$\mathrm{XX1}$}

\section{THE SIMPLEST LIVING THINGS}

$\mathrm{N}$ old times, if one wanted to compare a man to the 1 humblest and simplest of animals, one called him "a worm." But really a worm is a very elaborate creature, with skin, muscles, blood-vessels, kidneys, nervous system, pharynx, stomach, and an intestine, and is built up by hundreds of thousands of protoplasmic cells. Shakespeare got nearer the mark when he made one of his uncompromising professional "murderers" exclaim, as he stabbed the young Macduff to the heart, "What, you egg!" An egg is a single cell or corpuscle of protoplasm, and the simplest living things are of the same structure-mere units, single corpuscles of protoplasm, often less than the one-thousandth of an inch in diameter, and invisible except with the microscope, though in some cases big enough to be seen by the naked eye as they swim or crawl in a glass of pondwater. Many thousands of kinds of these simplest animals and plants have been carefully recorded, distinguished from one another, and named by naturalists.

Many of these unicellular animals (or "Protozoa") crawl by a curious irregular flowing movement of the viscid tenacious protoplasm of which they consist. There is no firm coat or cell-wall, only the thinnest pellicle on the surface. The Proteus-animalcule (Fig. 
$36 \mathrm{~A})$ is so called because of its constant change of shape; it is also called Amœba on this account. It flows out into broad, sometimes elongated, finger-like processes, of which one or several of different sizes may be formed at the same time, and then quickly disappear as the whole creature moves. Solid particles of foodminute unicellular plants-are engulfed by the moving viscid protoplasm and digested within it - that is to say, chemically dissolved, just as food is digested in the stomach of a big animal. The colourless cells of our blood and lymph (Fig. 36B) are called "amœboid," because of their identity with an Amcba in shape and movement and digestive power. In some of these animalcules (sun-animalcules and others) the processes of the protoplasm are in the form of very fine, long spreading threads which entangle a food particle, and then contract, drawing it up into the disc-like central body.

A whole group or division of these simplest animals are provided with special moving or vibrating hair-like extensions of the protoplasm called "cilia," that being the Latin name for "eyelashes," to which they are compared. These cilia are arranged with great regularity in rows, circlets, or spirals, on the surface of the "cell." They are found not only on cells which are independent unicellular animals and plants, but also on cells which form the clothing or surface layer of many larger animals (Fig. $40 \mathrm{~A}$ and B). Thus, in ourselves, they are found lining the windpipe, and they also line the internal cavity of the brain and spinal cord. The gills of the oyster, and such shell-fish, and other parts of their skin, are paved with ciliated or cilia-bearing cells, set side by side in thousands. A single "cilium" is like a little lash of a whip, and is always making its lashing movement. For a fraction of a second it is straight and upright, then suddenly curves over and bends to one side with 
a "flick," and immediately recovers its upright position (see Fig. 29, p. I 31). All the cilia on one cell or one surface "beat" in the same direction, and with a common rhythm, so that if the cell is a free, independent animalcule it is driven along through the water by the rapid strokes of these numberless tiny "oars," or "paddles." If the cilia are on a surface-like the oyster's gill-they drive the water along and create a constant current. Each cilium consists of an elastic and a contractile fibre closely fused together: the contraction of the one part causes a flick or bending of the hairlike cilium, the elasticity of the other substance causes it at once to straighten out again.

The ciliated unicellular animalcules (often called the infusoria, because they flourish in decomposing "infusions") not only swim by means of their cilia, but have a definite mouth or opening in the firm outer layer of the protoplasm of the cell, into which solid particles of food are driven by whirlpool-like currents set up by special lines of cilia (Fig. 4IA $a$ ). The mouth leads through a definite "gullet" into the interior of the cell. Remember that the whole creature is but a single minute cell or corpuscle of protoplasm! It is only from the hundredth to the thousandth of an inch long-with nucleus ( $e$ in the figure) of denser structure within - just like, in essential structure and properties, one single cell of the many thousands which build up the liver, or are packed in layers to form our outer skin, or are piled side by side (by self-division) to make the stems and leaves of plants. Yet here is such a cell-self-sufficing. When it divides (as it does) the two resulting cells do not remain in contact as they do when a germ cell (a fertilised egg-cell) divides. They simply separate, and each swims away, and carries on its own life. Many of them are fitted out with these cilia as a most serviceable locomotor apparatus, and as pro- 


\section{SCIENCE FROM AN EASY CHAIR}

ducers of food currents driving the food right in to a permanent, definitely-shaped mouth. Some have also a

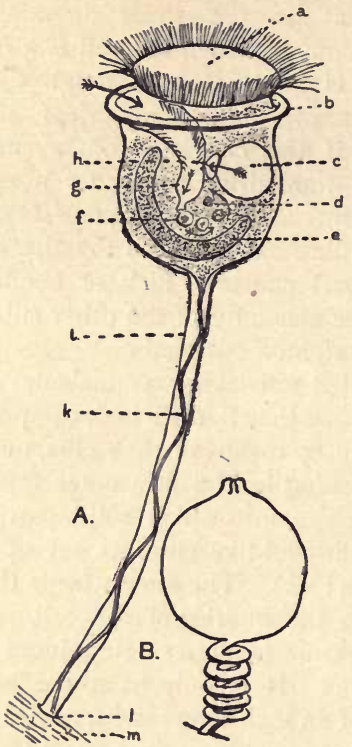

FIG. 4I. - Two specimens of a bell-animalcule (Vorlicella). A, extended. $B$, with retracted disc and coiled stalk. $a$, the ciliated disc; $b$, the firm ring behind the disc, called "peristome"; $c$, the pulsating chamber, called often the contractile vacuole; $d$, a completely digested particle of food on its way to be cast out through the gullet; $c$, the sausage-shaped nucleus; $f$, a particle of food which has just sunk into the protoplasm from the gullet, and is surrounded by a little water; $g$, the gullet; $h$, the reservoir leading from the pulsating chamber to the gullet; $i$, the hollow stalk; $k$, the spirally attached muscle within the stalk; $l$, the attachment of the stalk to a weed $m$.

separate opening by which the undigested remains of the food are extruded. They have also a liquid-holding 
cavity or series of cavities which, when distended, contract and discharge their contents to the exterior. This is an apparatus for "washing out "the protoplasm of the unicellular animalcule and getting rid of excretory products; it is definitely comparable in its use, though so different in origin, to the many-celled kidneys and bladder of higher animals.

One of the numerous kinds of "bell-animalcules" affords an excellent example in which we can watch the structures and life-processes in a single cell (Fig. 4I). It is a pear or bell-shaped body, little more than onethousandth of an inch broad, supported on a long, hollow stalk (though sometimes it breaks off from its stalk and swims freely); inside the stalk is a muscle ( $k$ ), so attached that when it contracts it shortens the stalk by throwing it into a close-set, corkscrew spiral (Fig. 4IB). The bell-shaped body has a relatively firm surface, beneath which is soft, viscid protoplasm and a large sausage-like nucleus. The body can expand itself so as to look like a solid bell or trumpet-shaped figure, with a flat, disclike surface where the "hollow" of the bell should be, or it can draw the edges of the disc together and assume the shape of a ball. A line of "cilia" is set on the edge of the bell's disc ( $a$ ) and takes a spiral course.

There is a deep pit on one side of the disc. This is the mouth. It is easy to feed this minute " egg" of a creature! A powder of fine particles-boiled bacteria, in fact, are what I have used-is introduced into the water between two slips of glass in which the bellanimalcule is displaying itself under our microsope. We see the particles whirling about in a vortex, hitting the disc of the bell-animalcule and then driven into the pit or cavity of the open mouth, whence they sink, enclosed in a sphere or droplet of water $(f)$ into the internal protoplasm! If the " boiled bacteria," before 
they are introduced, are stained with an alkaline blue such as blue litmus, they are seen in the course of a few seconds to turn red-showing that an acid has been secreted by the protoplasm (probably accompanied by a ferment) into the little sphere of water, in which the digestion of the boiled bacteria now goes on. In the course of a few minutes you will see the little sphere of water dwindling in size-the nourishing liquid being absorbed by the protoplasm-and then you will see the undigested fragments passed on by a slow movement to the vestibule or " pit" of the mouth, extruded through a temporary opening from the protoplasm, and whirled away by the water currents! If you colour the "boiled bacteria" with water-soluble anilin-blue —as I did many years ago-you will see that the colour vanishes from the particles taken into the bell-animalcule's protoplasm, and presently an independent sphere of bright blue liquid begins to form in the protoplasm. This sphere or globule is the renal organ mentioned above-here very simple and single (Fig. 40c). It is called the pulsating chamber or "contractile vacuole." It enlarges rapidly, filling with blue liquid (when special coloured food has not been supplied the liquid is colourless), then suddenly contracts, squirting its blue contents out through a special reservoir $(h)$ into the mouth-pit (as shown by an arrow in the figure).

The nucleus of these unicellular animals is often elongated (e), and shaped according to the general shape of the animalcule; but it is the same thing as the "nucleus" of all cells, whether of plants or animalsa denser "kernel" of protoplasm, limited by its own delicate sheath or membrane. It shows, like the cellnucleus of ordinary cells, a special affinity for certain dyes, which do not stain the rest of the cell, so that it can be made very obvious and clear when the animalcule 
is killed by alcohol, picric acid, or other preservative solutions, and then stained; and it shows a curious breaking-up of its substance into thread-like fibres when the animalcule is about to divide into two-as is seen also in all cells when the regular process of division of one cell into two commences. The larger animalcules have enabled us to find out what are the special properties of the nucleus of cells, as contrasted with those of the rest of the protoplasm. The trumpet animalcule (Stentor). is a single cell, and though only one-thirtieth of an inch long, is large enough to be cut into pieces by very skilful use of a fine blade. It is found that, if we cut the Stentor into four or five bits, all continue to "live"; that is to say, to swim about by the vibration of the hair-like cilia on their surface. But those bits which have no part of the nucleus in them die after a few hours. They cannot take nourishment nor grow. On the other hand, all the bits which comprise a slice of nucleus commence to contract, and shape themselves like the original Stentor, then form a mouth, and take nourishment, and grow up to be fully-sized, complete Stentors-animalcules like that by the cutting-up of which they were formed. This and similar experiments are held to prove that the processes of nutrition, growth, and production of specific form are dependent on the nucleus. In its absence, you may have contractility and active movement for a time, but no repair, no building-up of new material, no directed or seemingly "purposive" movement. Such movements, viz., advance in one direction, arrest, hesitating, or exploring movement to the right and left, followed by rapid retreat or advance in a straight line, are often exhibited by these minute animalcules, and cannot be distinguished in character from those, say, of a fly or even of a mouse.

These facts throw a great light on the significance 
of the structure of the protoplasmic corpuscle which we call a "cell," and show that the universal presence of the nucleus in every "cell" is due to the fact that it plays the most important part in the life of the cell. It is the seat of control, and contains substances in virtue of which the changes which constitute growth and form-production take place, and in the absence of which the rest of the protoplasm cannot "carry on," although for a time it lives; that is to say, remains chemically undecomposed, and shows active movement. At the same time, we must not underrate the importance of the general protoplasm, without the presence of some of which the nucleus cannot do its work, nor even exist. It is no wonder, then, that when a cell divides, there are curious and elaborate proceedings in the nucleus, by which each daughter cell gets its due half of the all-important nuclear substance.

When a cell divides the fission or splitting of the cell is preceded by peculiar changes in the nucleus. There is a material in the nucleus of every cell - of those which are simple animalcules, as well as of those which are germ-cells and sperm-cells, and of those which form, heaped up in enormous numbers, the living substance of larger animals and plants - a material which is an elaborated sort of proteid (see p. I 85 ) and stains strongly with carmine, logwood, and such dyes, and is called "chromatin." It exists often in the shape of minute granules and filaments (Fig 42a), but always takes on, sooner or later, the form of an irregularly undulated thread or threads. When the cell is about to divide into two-as all growing and active cells do-the thread arranges itself like a zigzagging girdle around the equator of the globular nucleus (Fig. 42b). The margin of the nucleus then seems to melt away into the general protoplasm, and the zigzag bits of the stainable thread break from each other, forming a ring-like group of 
$\mathrm{V}$-shaped pieces (Fig. 42c). There is a remarkable fact as to the number of these V-shaped pieces. They are identi-

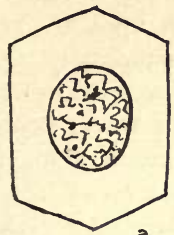

a

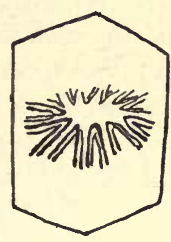

d

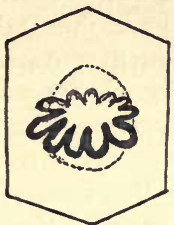

b.

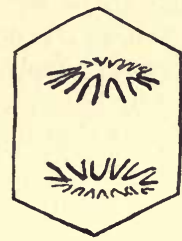

e.

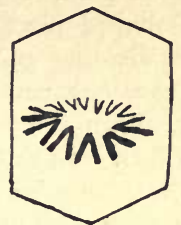

c.

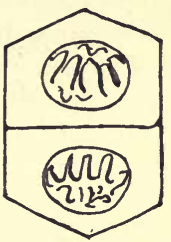

f.

FIG. 42.-Six successive stages in the division of a "cell," to show the appearance of the V-shaped filaments of colourable matter or chromatin. $a$, resting-cell, with chromatin dispersed as fine irregular filaments in the nucleus; $b$, the chromatin takes the form of a wreath with twelve loopsit lies horizontally across the cell; $c$, the loops break from one another, and form twelve separate V-shaped pieces; $d$, each of the twelve pieces divides along its length into two parallel V-shaped pieces; $e$, the divided pieces now separate from one another, so as to form two wreath-like groups of twelveV-shaped pieces at each end of the cell ; $f$, the wall of the cell forms across between the separated groups of V-shaped pieces, which lose their regular arrangement. Each group becomes enclosed in a capsule, and is the nucleus of a new cell. This is the regular process of cell-division, and the mode in which the chromatin of the nucleus is broken up, so as to be equally shared by the two daughter cells. In some species of animals the cells have as many as thirty-six V-shaped chromatin bodies; in others as few as two. Different plants also show a similar difference in the number of chromatin bodies characteristic of the species.

cal in number in all the cells of one species or kind of animal or plant, but may be of a different number in 
allied species. The salamander has twenty-four of them; some worms have only two, some insects thirtysix, some plants eight, others twelve, and so on. When the $\mathrm{V}$-shaped pieces have thus taken up their position in the dividing cell, each splits longitudinally, so as to form two V-shaped pieces lying one over the other (Fig. 42d). Then the halves separate and travel away from each other. In this way two circlets, each made up by the correct number of $\mathrm{V}$-shaped pieces, come into place at opposite sides of the cell (Fig. 42e). After this the protoplasm becomes nipped in between the two circlets so as to separate the cell into two halves, each with its circlet of exactly the correct number of V-shaped pieces of "chromatin" formed by the splitting of those of the parent cell (Fig. $42 f$ ). It is in this way that the nuclei of the new cells are accurately provided with not merely half of the nuclear chromatin of the mother cell, but with half taken from all parts of it, owing to the threadlike form of the chromatin and the longitudinal splitting of the thread.

Fertilisation of the egg-cell by the sperm-cell consists essentially in the junction or fusion of the nuclear chromatin threads of the egg-cell with the nuclear chromatin threads of a single sperm-cell or spermatozoon, which sinks into the egg-cell and fuses with it. This has been witnessed and studied with the greatest care. The leading fact of interest is that the egg-cell and the sperm-cell have only half the number of $\mathrm{V}$-shaped nuclear pieces which the ordinary cells of the same animal or plant possess. Thus a salamander's ripe egg and ripe spermatozoid have each only twelve V-shaped pieces-not twenty-four. This is brought about by the parent cells, which divide to form the egg-cell of the fermale and the spermatozoid of the male, not splitting their V-shaped nuclear bits; consequently, the number is 
reduced to half (that is, twelve) in the daughter cells resulting from the division. Accordingly, when the fusion of egg-cell and sperm-cell occurs-each bringing twelve V-shaped pieces-the proper number is reestablished, namely, twenty-four. In the first division of this fertilised germ-cell-the cell resulting from the fusion of egg-cell and sperm-cell-the V-shaped nuclear pieces split in the regular way, and the first two embryocells are formed, each with its twenty-four pieces. Each of these cells undergoes the regular process, and so by continued growth and division into two an immense series of cells are produced, which may separate as they form, or in the case of multi-cellular creatures, remain in continuity with one another as a bulky plant or animal. Clearly the whole process arises from the value to the growing mass of protoplasm of having its substance closely sown or dotted with centres of nuclear matterthat specially active, co-ordinating material-and of having those centres of equal volume and quality; and, lastly, of having that nuclear matter equally, or nearly equally, derived from the male and female parent, It is, however, not certain from observation of what occurs when the twelve male and twelve female $\mathrm{V}$-shaped pieces (or whatever the number may be in any given animal or plant which have become grouped together in the fertilised germ-cell) split and separate to form the nucleus of two new cells - that exactly twelve male and twelve female pieces go into each of the new cells. It is certain that twenty-four pieces go into each, but although it is possible that exactly half of them are male and half female in origin, it is not certain from observation that this is necessarily so. Supposing different proportions to obtain in each of the two first embryocells, it would help to account for the facts that offspring are not an exact blend of their parents in all their 
qualities, and that all the offspring of the same two parents are not exactly alike, but often very different from one another.

Some of the simplest living things, consisting of but one microscopic cell, are animals, and some are plants. The essential difference between an animal and a plant is shown very clearly by some of these microscopic creatures. Animals feed on the flesh or "proteid" substances manufactured by other animals or by plants; they also feed on oils or fats, and on the sugar and starch manufactured by other animals or by plants. But they cannot construct these "foods" themselves from the simpler stable chemical compounds called "mineral bodies," which, nevertheless, contain the elements they require-carbon, nitrogen, hydrogen, and oxygen. Such stable mineral bodies are carbonic acid, ammonia, and water. In fact, ordinary "smelling salts" (which is chemically carbonate of ammonia) dissolved in water, if we add to it a trace of phosphates, sulphates, and chlorides of potash, soda and lime, contain all the actual chemical elements that an animal needs. Yet no animal can be nourished by such a "mineral" soup.

On the other hand, it is the special distinction of plants - of green plants, be it noted-that they can feed on this simple diet, and, moreover, cannot feed on anything else. The green colouring matter which gives its beautiful tint to the grass and weeds and the leaves of the big trees which clothe the earth is absolutely essential in this process; so also is sunlight. The living protoplasm of the green-coloured parts of plants is crowded with microscopic discs or plates of a brilliant transparent green colour. The peculiar substance causing the colour is called "leaf-green," or "chlorophyll." It can be dissolved out of a leaf, not by water, but by spirit or by ether, and separately studied. It may be seen in solu- 
tion (to cite a commercial instance) in the liqueur known as "crême de menthe," being used to give its fine green colour to that preparation. Sunlight shining on to the green parts of plants is "screened" or "strained" by the leaf-green, so that only some of the coloured rays pass through it, and it is only by this peculiarly "strained" green sunlight that the protoplasm of the cells of the leaf is stimulated to its remarkable chemical activity. The carbonic acid in the air or in the water in which the green plant is living is taken up by the protoplasm. Carbonic acid consists of oxygen and of carbon. The protoplasm, when the green sunlight acts on it, actually takes out of carbonic acid and throws off as a gas (seen as bubbles in the case of a water plant) some of its constituent oxygen, thus keeping up the supply of free oxygen in air and water. Then at the same time it combines the carbon and the rest of the oxygen with water (hydrogen and oxygen) inside itself, forming solid starch, which, with the microscope, we can see actually manufactured as little oblong grains in the green cells. Not only this, but the element nitrogen is, so to speak, "forced" in other cells of the plant to combine with the three elements of the newly-formed starch (carbon, hydrogen, and oxygen), and thus the first steps leading to the building up of those wonderful bodies, the proteids, are passed. Nothing of the sort can be done by the protoplasm of an animal cell.

Consequently we distinguish among the simplest living things those which are provided with leaf-green, and feed, as do the larger green plants, on dissolved " mineral" solids and gases. There are many thousands of kinds of them-single simple cells. Some are known to microscopists as Diatoms and Desmids - often of curious spindle or crescent-shape, others star-like. The diatoms form on their surface a delicate, wonderfully- 
sculptured coat of glass-like silica (quartz), which resists destruction and persists long after the protoplasm is dead and washed away. They are favourite objects for examination with the microscope on account of their great beauty and variety.

Those simplest living things which have not got leafgreen to enable them to feed on mineral food mustunless they are parasites (as many important kinds are)get their food, as do bigger animals, by feeding on the solid substance of other living things. All living things are, in fact, ultimately dependent on the green plantswhether microscopic or of larger kinds-not only for food, but for oxygen gas. If you could take away green plants altogether from the world, the animals would eat one another and use up the oxygen gas of the atmosphere, and at the last there would be a few only of the strongest left, like the last survivor of the shipwrecked crew of the Nancy Bell, and even they would be suffocating for want of oxygen. The single cells, which are independent animalcules, and feed like animals on whole creatures smaller than themselves, or on bits of the fresh substance of other animals or of plants, are of extraordinary diversity of form and activity. Unlike the unicellular plants, whose food is dissolved in the water in which they live, the single-cell animals of necessity take their food in "lumps" into their inside and digest it, and so their cell-protoplasm has either a soft surface which can take up a food-morsel at any point or it has a firm surface with a definite mouth, or aperture, in it (see Fig. 4I) where the mouth is marked by an arrow. Many of them, especially those with soft glutinous protoplasm, which extends from the main-mass in long threads or branching processes searching for food-morsels, form marvellous, perforated shells by chemical deposit, either of silica or limestone (Radiolaria and Foraminifers). 
The kinds with a firm or tough surface to the cellprotoplasm and a permanent mouth and gullet leading into the cell-substance have very usually a single large lashing-whip (Flagellata), which drives them through the water in search of prey, or they are clothed with hundreds of such lashing threads of smaller size-the "cilia" described above (p. 195)-arranged in rows or circles, whence these animalcules are called "Ciliata." The ciliates or one-celled animals are enabled by their cilia to move with all the grace, variety, facility, and apparent intelligence of the highest animals, and also to create powerful vortex-currents by which food particles are driven into the cell-mouth.

It is a most remarkable and thought-stirring fact that here we have "animalcules" which are no more than isolated units of the kind and structure which go by hundreds of thousands to build up a larger animal - just as bricks are units of the kind which to the number of many thousands build up a house. And yet each of these free-living units has a complete organisationmouth, pharynx, renal organ, locomotive organs, and so on-similar in activity and general shape to the system of large, capacious organs built up by the agglomeration of millions of cell-units to form the body of a higher animal. It is as though a single brick were provided with door, windows, staircase, fireplace, chimneys, and wine-cellar! It is clear that there is only a resemblance and not an identity of origin between the organs of the multicellular animal and those of the single-celled animalcule. The history of the growth of an animal from the single egg-cell, and also the series of existing many-celled animals, leading from simple forms to the most complex, proves this. And in view of that fact the wonderful elaboration of these diminutive creatures -many of them so small as to be absolutely invisible 
to the naked eye-is all the more curious and impressive. We have, in fact, parallel organisation and elaboration of structures with special uses, in two absolutely separated grades or strata of living things-the one grade marked off by the limitation that only a single cell, a single nucleated corpuscle of protoplasm, is to be the basis and material of elaboration - the other and higher grade permitting the use of millions of single cells, of endless variety and plasticity, capable of hanging together and being grouped in layers and tissues, in such enormous masses that an elephant or a whale is the result. And we see that the same needs are met, not actually in the same way, but in the same kind of way, in the two cases -the food-orifice, the cilia, and the "pulsating vacuole" of the unicellular animalcule do the same services as those done by the structurally different mouth, legs, and kidneys of the elephant. 


\section{XXII}

\section{TADPOLES AND FROGS}

THE season of tadpoles is not a season recognised 1 by housekeepers and gourmets (except in France, where frogs are eaten in April), but one dear to schoolboys and all lovers of Nature. The ponds on heaths and in the corners of meadows now show great masses of soft jelly-like balls of the size of a marble, huddled together and marked each by a little black spot at its centre, as big as a rape-seed. This is the "spawn" of our common frog. The spawn of the common toad is very similar, but the black spots are set in long strings of jelly, not in separate balls. The little black body is precisely the same thing as the yellow part of a hen's egg, and the jelly around it corresponds to the "white" of the bird's egg; but there is nothing to represent the shell. The "yelk" of the bird's egg is, it is true, much larger, but corresponds to the black sphere of the frog's egg-the actual germ-and is like the latter a single protoplasmic cell, distended with nourishing granular matter. It is the excess of this matter which makes the yellow ball of the bird's egg so much bigger than the black or rather deep-brown germ of the frog. The little black spheres elongate from day to day in the warm spring weather, and at last the minute tadpoles (see Fig. 43 and its explanation) break loose from the jelly, 
hanging on to its surface by aid of a tiny sucker, and feeding on the minute green vegetable growths which

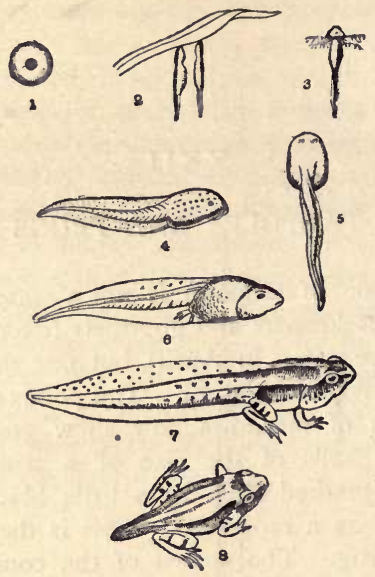

Fig. 43.-Stages in the growth from the egg of the common frog-drawn of the natural size. I. Egg in its jelly-like envelope. 2. Very young tadpoles adhering to weed by their suckers (placed just below the mouth). 3. Very young tadpole, showing two pair of external gills : a third pair is present, but so small as to be invisible without magnification. $4,5,6$. Stages in the later growth of the tadpole: the external gills have disappeared, but the legs have not yet made their appearance. 7. Tadpole of full size, with fore and hind legs. 8. The tadpole has now become a small frog, and has left the water. The tail has shrunk, but has not entirely disappeared : it remains throughout life hidden by the skin and the large thighs of the growing frog. This figure has been kindly supplied by Messrs. Macmillan \& Co., from Dr. Gadow's volume on the "Amphibia and Reptiles," in the Cambridge Natural History.

have appeared all over the jelly-like mass. Their rate of growth depends very much on the temperature, and 
is much more rapid in Italy and the South of France than in England. At first they are so small that it is difficult to distinguish, except with a pocket-lens, the little black plume-like gills on each side of the head, and it is only as they grow bigger and lose these little plumes that the young things assume the characteristic shape of a rounded head-really head and body-with a long flattened tail which strikes vigorously to the right and left, and enables the tadpole to swim like a fish.

I suppose that every one, or nearly every one, knows that these swarming little black tadpoles are the young of frogs and toads. As the season goes on they grow to as much as an inch and a quarter (sometimes an inch and three-quarters) in length, and develop a number of golden metallic-looking spots in the skin, which give them a brownish hue. Both the fore and the hind limbs have now developed, but are hidden beneath the skin, and all this time the tadpole is breathing, like a fish, by means of gills, concealed from view by a fold of skin. Very early it acquires a pair of lungs, and by the time the legs break through the skin (the hind legs do so first) the lungs are inflated, and help in respiration. Now the head becomes modelled like that of a young frog, the tail ceases to grow, its flat transparent border is absorbed and eaten by "phagocytes," and the legs become strong and large. Soon the gills atrophy, and the young creature crawls out of the water and spends much of its time in the damp grass and herbage near its native pond, rapidly assuming the shape of a frog. An interesting fact is that all the time that it is a tadpole the little animal eats vegetable food or soft animal food (even other tadpoles), has horny lips, and a very long intestine, coiled like a watch-spring. But as soon as it leaves the water it becomes purely carnivorous, feeding on small insects and worms, and its intestine straightens 
out and becomes, relatively to the increased size of the body, quite short.

Even those who know frog-spawn when they see it and something of the history of the growth of the tadpole and its change into the young frog or toad (as the case may be) do not, as a rule, know about the laying of the eggs. In the early spring (end of March) the full-grown frogs and toads which have passed the winter buried in holes and cracks in the ground in a state of torpor wake up and make their way to neighbouring good-sized ponds. In these the eggs are deposited. The male frogs wait for the females whom they seize from behind, placing their arms under hers and round the chest. They hold so firmly that nothing will persuade them to let go. They often retain their hold for days or even weeks. Sometimes by mistake they seize a fish and hold on securely to its head-a fact which has led to the belief among country-folk that the frog is an enemy of the carp, and tries to blind him by forcing his hands into the carp's eyes. At this season a frog will clasp your finger or the handle of a stick so persistently that you can lift him out of the water. A large pad of a black colour grows in the breeding-season on the inside of the first finger of the frog's hand, and is richly supplied with nerves. It is this growth which is sensitive and when touched sets up the cramp-like clasping action of the muscles of the arms. The eggs are eventually squeezed from the female's body, and are fertilised by the spermatic fluid of the male as they pass into the water. They are, when "laid," covered with only a thin transparent layer of albumen (or white of egg), and it is only after a few hours that this imbibes water and swells up into a ball-like mass around each little black egg.

Years ago I used to collect the spawning toads and 
frogs at Baden, near Vienna, in order to observe (in the laboratory of the celebrated microscopist, Professor Stricker, the most gifted of his day) the earliest changes in the little black egg, the size of a rape-seed, which follow upon fertilisation. Properly placed in a watch-glass full of water under a low power of the microscope one little egg could be watched for hours. If it had not been fertilised, nothing occurred. But if it had been, then there were strange movements of its surface and a puckering and sinking in along one definite line, coming and going, but at last becoming well marked like a deep furrow. Without actually splitting, the little sphere was divided by the cleft into two halves. Then, at right angles to the first cleft, a second began to form, and so on, until in the course of hours the sphere became divided on its surface like a blackberry. The separate pieces thus marked out are the first "cells," or units, of living protoplasm of the young tadpole. They continue to divide and to chemically convert the granular matter with which they are charged into living material whilst the mass slowly, in the course of days (taking up water for its increase in actual size), becomes elongated, and shows the rudiments of head, eyes, ears, spinal cord, and projecting tail. It is a fascinating task to watch this gradual development - and a difficult, but necessary, one (which has now been carried out in the minutest detail by patient students), to harden with chemical solutions the growing embryos taken at successive stages, to embed them in wax or paraffin (as Stricker was the first to do), and to cut them into the finest slices, then to clarify these slices in balsam-varnish, examine them with the microscope, and record and draw every "cell," every constituent unit, as they increase in number and complication of arrangement. That wonderfully difficult feat has now been carried out not only in the case of the frog 
and toad, but in the case of hundreds of different kinds of animals of all sorts. Thus we know the history of the growth from the egg in its minutest details in every kind of animal - the "cell-lineage" of the tissues of the full-grown animal traced back to the single original egg-cell.

The egg of animals is always originally a single "cell" - that is to say, a minute corpuscle of slimy consistence, with a dense capsulated kernel or "nucleus" within it. The kernel or nucleus divides into two, and the cell itself divides; each of the daughter cells again divides, and so the process continues, until thousands, and in larger animals millions, of cells are the result, as the mass of cells takes up nourishment and increases in volume. When (as is the case in many animals, e.g. starfishes, worms, and mammals) there is only a little granular food-material mixed in with the protoplasm of the egg-cell, that cell is of small size, only the one twohundredth of an inch in diameter (see Fig. 3I). But in the frog there is much granular food-material, and the eggcell is distended to the size of a rape-seed. When there is still more, as in the bird and many fishes, the egg-cell does not entirely divide as it does in smaller eggs on commencing growth after fertilisation. The protoplasm collects into a disc incompletely separated from the foodmaterial, and it is the disc only which divides into two four, eight, and ever so many more cells. Some of the cells resulting from the division of the disc form the embryo's body, and others spread, as they multiply, all over the rest of the egg-ball from its edges so as to enclose the granular food-material in a sac, called the yelk sac. In the frog, on the contrary, the protoplasm does not separate as a disc: the whole egg-cell or ball divides to form the embryo-cells, and the food granules are included in the substance of the dividing cells. 
"Growth from the egg" is a long story; we must revert now to the tadpoles and their parents.

There is a tradition that Dr. Edwards, the father of Henri and grandfather of Alphonse Milne Edwards, directors of the Natural History Museum of Paris, kept some tadpoles in a sort of cage sunk in the Seine, so that they could not come to the surface to breathe air nor escape on to the land, and that they grew to be very big tadpoles, much larger than the size at which tadpoles usually change into frogs. I tried to repeat this experiment when I was a boy-without success-and I have never heard of any one having succeeded with it. ${ }^{1}$ It is not cited or credited at the present day. But some thirty years ago it was discovered that something of this kind happens in the case of the Mexican salamander. The English "newts" and the so-called salamanders are creatures of lizard-like shape, which are closely related to frogs and toads. They lay eggs in the water, and the young are tadpoles, with beautiful large plume-like gills on each side of the head. The tadpole of the common English newt may either lose its gills and leave the water in the summer, if it was hatched early in the season, or may remain longer in the gilled condition, and grow to more than two inches in length, if it was hatched late. In certain lakes in Mexico there is a tadpole-like creature with gill-plumes, which grows to eight inches or more in length, and becomes adult and breeds when in that condition. It is known as the "axolotl," and was considered

${ }^{1}$ I am told by Mr. Boulenger, of the Natural History Museum, who is the greatest authority on these animals, that the explanation of this is that unawares Dr. Edwards made use of the young tadpoles of the obstetric toad (Alytes), which is very common near Paris, though it does not occur in England. These tadpoles regularly grow to be three inches and more in length (see Fig. 44 B). Dr. Edwards thought he had used the tadpoles of the common frog, but had, by accident, got hold of those of Alytes. 
to be a distinct kind of gill-bearing adult tadpole-like animal similar to some few others which are known (Siren and Necturus). When, however, they were brought to Europe and kept in a cage with only a small provision of water, some of these axolotls were found to leave the water, lose their gills, change their colour and shape in several respects, and become, in fact, transformed into a terrestrial salamander, of a kind already known in North America. It was thus established that the axolotl of the Mexican lake is nothing more nor less than the tadpole of a species of salamander or newt, which has "given up" the habit of leaving the water, and actually grows to full size, and lays its eggs without becoming converted into a gill-less land-dwelling creature! The greatest interest was excited forty years ago, when the discovery was made that, by gradually drying up the water in which the axolotl is kept, it can be induced to resume its transformation, and become changed into a salamander. Thus, the notion of converting the tadpoles of the common frog into very big tadpoles by preventing them from leaving the water, seems not to have been an unreasonable one.

There are some very big kinds of tadpoles, which are the young of toads of other kinds than our British species. In England we have only two kinds of frogs-the common frog and the edible frog-and two kinds of toads, the common toad and the natter-jack or crawling toad (distinguished by the pale line along the middle of his back). But on the Continent of Europe there are others besides those which we have. There is the beautiful little green tree-frog, and there are the fire-bellied toad, and the obstetric toad (the male of which carries the eggs after they are laid, coiled in a string around his hind legs); and then there is the little spur-heeled toad (Pelobates fuscus), which smells like garlic, and is remarkable for having a broad, horny claw on his heel. This toad is 
only about two inches and a half long (measured from snout to vent) when full grown, but its tadpole often
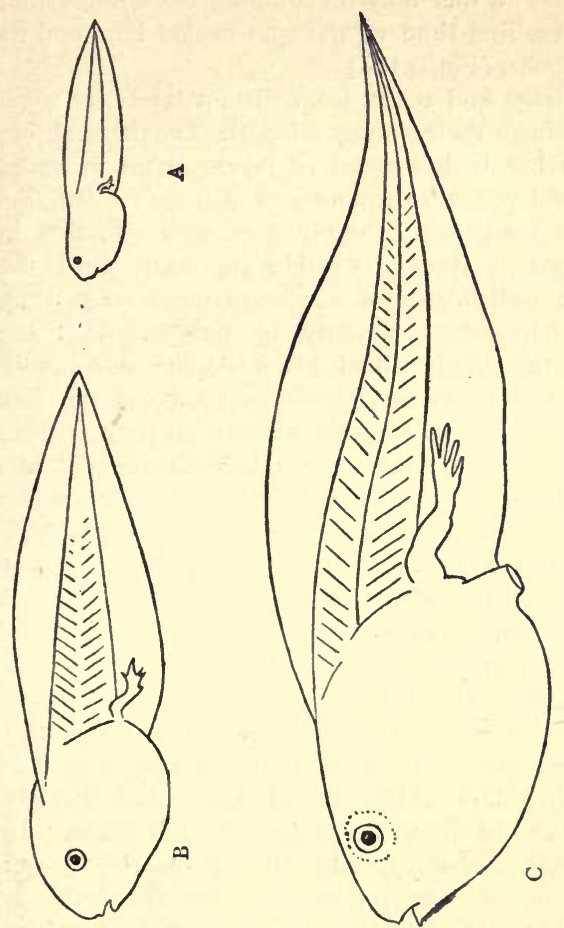

苞 ติ $<$ 遂金. (1) of

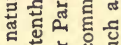

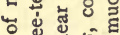

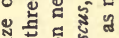
촌 का बा है

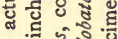
ฐ छूँ कू

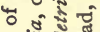

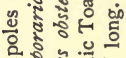
믈 논

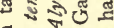

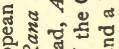

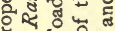
ज्ञ 纯 동. 讨. 兘

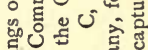
.

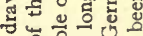

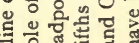

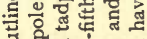

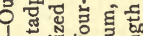
$\dot{\square}$ के . ज्ञ 近

exceeds four inches in length, and in rare cases attains the gigantic size of seven inches, so that it actually shrinks in size when it ceases to be a tadpole, and takes on the adult form. Many years ago I found some of these huge 
tadpoles in a pond near Antwerp, and thought they must be a realisation of Dr. Edwards' experiment. They were enormous, and it was only on bringing them home that I heard for the first time of the spur-heeled toad and its gigantic tadpoles (Fig. 44 C).

Among frogs and toads from distant lands are some which bring forth their young alive, the female retaining the eggs in her body instead of laying them in water. The black-and-yellow salamander of Europe (which, like the common toad, has a highly poisonous secretion in the skin) retains its eggs inside its body until the tadpoles are well advanced in development, when they pass from her-about seventy in number-into the water. In the closely allied black Alpine salamander only two, out of thirty or more eggs produced, develop. These two remain inside their mother until they have ceased to have gills and have become terrestrial airbreathing young salamanders like their mother. The Alpine salamander lives where there are no pools suitable for the tadpoles, and so they never enter the water, but remain inside the mother's body. Some experiments have recently been made with these two species of salamander by varying the conditions as to moisture in which the young grow to maturity, and results of considerable interest have been obtained. One of the most curious arrangements in regard to the young is seen in the Surinam toad, of which we had living specimens five or six years ago in the London Zoological Gardens. In this toad the skin of the female's back becomes very soft and plastic at the breeding-season. As she lays the eggs the male takes them one by one and presses them into the soft skin of her back, into which they sink. The eggs are thus embedded separately to the number of fifty or sixty, each in a little pit in the mother's back. They slowly develop, each in its "pit," the orifice of 
which is closed by a sort of lid. When the young have grown to the condition of little toads, they push open the lids of the pits and swim out of their mother's back. Specimens of these toads, with the eggs and young, in various stages, embedded in their mother's back, are to be seen in most museums of natural history. Toads and frogs catch their prey by throwing forward the sticky tongue which is attached near the front of the lower jaw, and so lick up their victim with startling abruptness. The Cape frog of South Africa (Xenopus), like the Surinam toad $(P i p a)$, has no tongue, and is also remarkable for possessing hard, pointed ends to its toes. It rarely, if ever, leaves the water. 


\section{XXIII}

\section{ABOUT THE STARS}

$7 \mathrm{HE}$ young astronomer in Two on a Tower-that 1 bitter-sweet story in which our great novelist Hardy tells of the weird fascination with which the study of the stars appeals to a sensitive nature, exclaims: "The imaginary picture of the sky as the concavity of a dome whose base extends from horizon to horizon of our earth, is grand, simply grand, and I wish I had never got beyond looking at it in that way. But the actual sky is a horror." "There is," he continues, "a size at which dignity begins; further on there is a size at which grandeur begins; further on there is a size at which solemnity begins; further on a size at which awfulness begins; further on a size at which ghastliness begins. That size faintly approaches the size of the stellar universe." "If you are cheerful and wish to remain so," he concludes, "leave the study of astronomy alone. Of all the sciences, it alone deserves the character of the terrible. If, on the other hand, you are restless and anxious about the future, study astronomy at once-your troubles will be reduced amazingly. But your study will reduce them in a singular way, by reducing the importance of everything, so that the science is still terrible, even as a panacea." The facts revealed by the study of astronomy which have this feature of ghastliness and terror relate to the enormous distances in space at which the stars are placed, and to their enormous number. 
One may sometimes see on the coast or in some marshland a "pile-driver" at work. At a quarter of a mile distance you can see the great weight hoisted up by cranks and chains above the "pile," which stands upright but not yet driven very far into the ground. You see the weight let go; it drops vertically on to the pile, and you watch it rising some two or three feet on its return journey upwards, when suddenly you hear the sound of a sharp blow, and only after an effort realise that the sound was made more than a second ago, and that the workmen have had time to raise the weight $3 \mathrm{ft}$. before the sound travelled to you. Sound travels less than a quarter of a mile in a second. Light also takes time to travel, but it advances ever so much more quickly than sound, namely, 186,000 miles (and a bit more) in a second. It is, therefore, easy to calculate the number of miles traversed by light in a minute or in a year. There are thirty million seconds in a year. The light of the sun takes eight minutes to reach the earth, so, instead of stating the number of miles of this distance, we may say that the sun is eight "light-minutes" distant from the earth (about 89,000,000 miles). This is an enormous figure. The sun and his planets may be represented proportionately by a golden ball a foot in diameter, and a number of little spheres varying in size from that of a dried pea to a boy's marble, placed at distances from the golden ball varying from $50 \mathrm{ft}$. to $200 \mathrm{ft}$. Such a model is shown in the Museum of Practical Geology in Jermyn Street, London. Minute and scattered far apart as the planets of the solar system appear when thus represented, yet the solar system is a compact little group when we come to consider the distance from it of the other sunsthe "fixed stars," which exist literally in millions beyond it. The nearest of these stars (its name is Alpha Centauri) is no less than three light-years distant from us. A light- 
year is five and a half billion (that is, five and a half million million) miles. The nearest sun to us after our own sun is, therefore, about sixteen billion miles away and if its light were suddenly extinguished, we should not know of its extinction for three years.

How many-we may well ask-how many of these fixed stars-suns like our own-are there? Roughly speaking, we can see with the naked eye, reckoning both the northern hemisphere and the southern together (for the stars seen from the former are other than those seen from the latter), about 8000 . Not many after all, one is inclined to say. But stop a minute and hear what the telescope reveals. With the best telescope about one hundred million can be seen, less and less brilliant and more difficult to see in proportion to their remoteness. And now we go further even than that. For within the last thirty years the great science of astronomy has been rejuvenated by the application of photography to its task. The invention of the "dry" plate, a sensitive photographic plate which does not spoil by prolonged exposure as the "wet" plate does, enables the astronomer to keep his telescope fixed by slow-moving clockwork on to a given region of the sky for four or five hours or more, and the very faint stars, invisible by the aid of the most powerful telescope-stars the light from which is so feeble that it could not affect the plate in a few seconds or minutes, have time by the continued action of their faint light to print themselves on the plate and sign, as it were, a definite record of their existence for man to see and measure, though they are themselves for ever invisible to his eye. It is not possible to say how many may be recorded in this way by photography; it depends on length of exposure. But some thousands of millions of stars can certainly be so recorded. These "unnumbered hosts" are of various degrees of brightness, and by 
methods which astronomers have invented, but caunot be described here, it is actually known how they differ in size from one another (many are far bigger than our sun), and with some approach to certainty, how far off they are. Stars of four, five, ten, and more "light-years" away from us are well known. Astronomers actually estimate the decreasing abundance in space of stars as one passes from a sphere or spatial envelope of fifty light-years' distance to one of 250 light-years. Finally, reasons have been given of late for considering many of the "photographic" stars to be at a distance of 32,000 light-years. I will not produce the awful figure in miles, but the reader can refer back to the number of billion miles in a light-year! And what is beyond that? No one has seen, nor can any one guess. We cannot imagine a limit to space; neither can we imagine unending space dotted with an infinity of suns!

It is a legitimate and, indeed, a necessary inference, from what we know of these millions of suns-intensely hot, light-giving spheres-that they, too, like our own sun, are accompanied by much smaller bodies, planets which circle round them, as our sun's planets circle round him. Those planets have cooled down, as have those of the solar system, and so do not give out light. In any case, they are too small to be seen at so vast a distance. It is, on the whole, probable that the changes on someindeed, many-of these planets have led to the production of living material similar to, but not necessarily identical with, that on this earth. It is, on the whole, more likely than not that there are intelligent beings existing on the planets of thousands of suns invisible to our eyes: suns revealed only by the print on a photographic plate of their light, which has taken thousands of years to travel from the regions of unseen obscurity to us. To have arrived by sober observation and reasoning at this con- 
ception is, indeed, a tremendous flight of human thought and ingenuity!

It is the courage, the audacity-one may almost call it the superhuman calmness-of astronomers, in the face of this truly overwhelming immensity - that not only redeems their study from the oppressive and terrifying character with which it at first assails the human spirit, but gives to their proceedings and discoveries, so far as the ordinary man can follow them, an unequalled fascination. The daring, the patience, the accuracy, and the supreme intellectual gifts of the great astronomers rightly fill other men with pride in the fact that there are human minds capable of revealing things of such stupendous vastness and of indicating their order and relation to one another. It is a splendid fact, and one which must give hope and courage to all men, that the astronomer's mind does not totter-it is equal to his task. Astronomers are, in fact, triumphant: they are very far indeed from suffering from the depression which Mr. Hardy's young stargazer experienced.

Among the many conclusions of astronomers as to the movements of the "heavenly bodies" none is more strange and mysterious in its suggestion than that recently arrived at to the effect that in all this vast array of millions of stars, the limits of which we can neither discover nor imagine, there are two huge streams moving in opposite directions, and in one or other all the stars are involved. Whence do they start? Where are they going ? There is no answer. Another conclusion, which is arrived at quite simply by the examination with the spectroscope of the light coming from the star named Vega by astronomers, is that our sun and its attendant planets are moving towards that star. It is true that it is many billions of miles away from us, but we are rushing towards it somewhat rapidly according to mundane notions- 
namely, at the rate of nineteen miles a second! That, I think, is a fact likely to make the sentimental young astronomer as miserable as any of the records of immensity. In fact, the only comfort to be got in view of this fact is in the enormous distances which separate us from other stars, and the length of time which must elapse before any serious consequence can ensue from this alarming career. And there is further the probability that the general result of attractions and repulsions in the vast roadway of space will, when the time comes, take us safely past Vega, just as a motor-car passes safely through the traffic and obstructing "refuges" and lampstandards of the London streets as you recline in it, abandoned to the natural forces described as "chauffeurs."

The spectroscope has done no less than photography to reanimate the study of astronomy. The fact is that, with these two helping means of observation, it has become possible for the ordinary man to witness and appreciate some of the discoveries of astronomers, though the true and accurate handling of all that is revealed concerning the stars is essentially a matter of measurement, and therefore only to be dealt with strictly by mathematicians. The desire to obtain ever more and more accurate measurement of the movement and the size of the heavenly bodies is the mainspring of all astronomical discovery, and, indeed, the attempt to gain more and more detailed measurement of the factors at work is the motive-more or less immediate-of all accurate investigation of nature. Recently the astronomers of the Royal Observatory at Greenwich have photographed the new comet (the third of 1907) in a way in which no comet has ever been photographed before. On many consecutive nights for several weeks they were at work photographing it on the dry plate, at intervals of two or three hours, and the pictures obtained (which I have 
seen at the rooms of the Royal Astronomical Society) show the most wonderful changes of form of its tail, so that they look more like the record of the changes of some living creature than those of a heavenly body. Already, in October I909, Halley's comet, which has been anxiously awaited, has been seen, though it is not expected to be bright and visible to all until May i9ı. Comets are among the exceptional delights of the astronomerthat is to say, big comets, for two or three small comets visible only by a telescope or by photography turn up every year. Some comets are expected visitors, others make their appearance quite casually, some because they apparently have no regular period, some because that period is as yet undiscovered. Edmund Halley was the first to discover the law of movement of a comet and to predict the return in 1758 of that seen in 1682. He did not live to witness the verification of his prediction. This comet, now called Halley's comet, was, he conjectured, the same which had appeared in 1531 and in $1607 . H$ H prediction of its return proved to be a year out (owing to perturbations caused by Neptune and Uranus, two planets undiscovered in his day), but it appeared in 1759, and went round once again and reappeared in 1835, and now is eagerly expected by astronomers to appear in full brilliancy in I9IO. Its period is about seventy-five or seventy-six years. 


\section{XXIV}

\section{COMETS}

COMET is so called from the hair-like stream of A light or "tail," which stretches to a greater or less length from its bright head or "nucleus." A large comet, when seen to greatest advantage, may have a tail which stretches across one-third of the "vault of heaven," and may be reckoned by astronomers at as much as one hundred and twenty million miles long. Donati's comet - which some of my readers will remember, as I do, when it visited us in I858-was of this imposing size. Halley's comet, on the other hand, when it was last "here," namely, in I 835 , showed a tail estimated by astronomers to be fifty million miles long. The tail was more than twice as long when Halley's comet appeared in 1456 . There was a big comet "on view" in $18 \mathrm{II}$ - the year celebrated for its wine -and in recent times a fine comet appeared in $186 \mathrm{r}$, and another (Coggia's comet) in 1874 .

The ancient records of comets are naturally full of exaggeration. Up to Milton's time-two hundred and fifty years ago-they caused the greatest terror and excitement by their sudden appearance in the sky. This is due to the fact that mankind from the very earliest periods of which we have record has not merely gazed at the "starry host" by night in solemn wonder, but even in early prehistoric times studied and watched the stars so as to 
know much of their movements and regular comings and goings. The earliest priests, the earliest "wise men," were those who knew the stars and could fix the seasons by their place; the earliest temples-Stonehenge, and others older still-were star-temples or observatories, and their priests were astronomers. To such a pitch did reverence for star-knowledge attain that our ancestors confused the astral signs of changing season and cycle with the cause itself of change, and attributed all kinds of mundane events and each man's fate to "the influence of the stars." Hence the sudden appearance of a flaming comet was held to be a portent, and was always supposed either to foretell or even to produce some very unpleasant event, such as a big war or a pestilence, or the death of some one supposed to be of consequence. The earliest Greek poetry enshrines the superstition, which is handed on by Virgil, and finally by Milton. In Pope's translation of the Iliad we find the helmet of the terrible Achilles described as shining

"Like the red star, that from his flaming hair Shakes down diseases, pestilence, and war."

And Milton, in 1665 , in his Paradise Lost, wrote-

$$
\text { "On th'other side, }
$$

Incenst with indignation, Satan stood Unterrifi'd ; and like a comet burn'd, That fires the length of Ophiuchus huge In th' Arctic sky, and from his horrid hair Shakes pestilence and war."

In this year of the celebration of the tercentenary of Milton's birth, it is not a little curious to find that John Milton, himself a scholar of St. Paul's School, wrote those lines when Edmund Halley, the future Astronomer Royal, had just entered the same great school, then standing in St. Paul's Churchyard, as it did when I was "one of the fishes," and used to see men hanging in the Old Bailey 
-I once saw five ${ }^{1}$-on Monday mornings as I passed on my way to the school. To a Pauline it is not without significance that the return of Halley's comet is awaited within a year of Milton's tercentenary, and that the greatest astronomer and the greatest poet of their age were London boys and Paulines.

Ancient records tell of comets of gigantic size, of the shape of a sword, the head as big as the moon, and so on. There is no reason to suppose that within historic times there have been any much bigger than that of 1858 . Milton, in the lines above quoted, was not referring to an imaginary comet, but to one which actually did appear when he was a boy of ten ( 1618$)$, in the constellation called Ophiuchus. It was of enormous size, the tail being recorded as longer even than that of 1858 . It was held responsible by educated and learned men of the day for disasters. Evelyn says in his diary, "The effects of that comet, 1618 , still working in the prodigious revolutions now beginning in Europe, especially in Germany." The comet of 1665 was, with equal assurance, regarded as the cause of the Great Plague of London. In that year was published the first number of the Philosophical Transactions of the Royal Society of London, then recently founded "for the promotion of natural knowledge." It contains an account of a paper by a learned French gentleman, M. Auzout, in which an attempt is made to predict the movements among the stars of the comet of I664. Astronomers had long known and been able to predict the movements of the planets and the swinging of the constellations, but, as the French author observes, "all the world had been hitherto persuaded that the motions of comets were so irregular that they could not be reduced to any laws." He also hoped, by examining the movements of the comets of $166_{4}$ and $166_{5}$, to determine "the ${ }^{1}$ The pirates of the Flowery Land. 
great question whether the earth moves or not." At that time the earth was "suspected" to move round the sun, but no proof of that motion had been given. M. Auzout did not succeed in his laudable attempt, simply because Newton's great discovery of the law of gravitation had not then been made.

Edmund Halley was the intimate friend and passionate admirer of Newton. He paid out of his own pocket for the publication of Newton's Principia by the Royal Society in 1686, the society having expended all its available funds in printing a great work on Fishes (which shows how at the first, as now, the society cared for the whole range of the study of Nature). Halley was able to show that comets move regularly round the sun, in obedience to the same law of gravitation which controls the movements of the planets and of our earth itself; so that many of them are regular members of the solar system. Halley especially calculated out the form of the orbit of the comet of 1682 as an ellipse, and the time of its journey and recurrence, or "period," as it is called, which he showed to be about seventy-five or seventy-six years. He predicted its recurrence in 1758 . Halley died in 1742 , at the ripe age of eighty-six, having, amongst other good deeds, founded the Royal Society Club, which still dines every Thursday in the session. His comet reappeared in I759, a few months later than he had, owing to incomplete details used in his calculation, expected; but the accuracy of his scheme of its movement was demonstrated. It duly appeared again in 1835 , and it is now awaited in the spring of 1910. Halley himself had identified his comet with that of 1607 and of 1531 , and lately, by the aid of records from an ancient seat of astronomical observation -actually from China-it has been traced back to the month of May in the year 240 B.C. It has caused consternation and terror times enough since then, of some 
of which we have record. Finally, it has become the leading instance of the triumph of scientific knowledge and accuracy over ignorance and superstition. Halley's comet caused great alarm in Rome in the year 66 A.D. A thousand years later (1066) it was seen when William the Conqueror was preparing to descend on the coast of England, and is actually represented in the Bayeux tapestry. A number of men are drawn (or rather "stitched"), with fingers pointed and eyes raised to a shape in the sky which resembles a star-fish with a large triangular-ribbed petticoat attached to it, ending in eight flames or tongues (Fig. 45). The picture is labelled "Isti mirant stella." There is now no doubt, as accurate calculations have demonstrated, that William the Conqueror's "star" was Halley's comet-a fact which must give its reappearance in 1910 an additional interest in the eyes of Englishmen.

The shape given to the representations of stars in old pictures and engravings is a puzzle. Why do they represent a star by the shape of a star-fish? No star ever looks like that, or produces a picture of that shape on the retina. The thing is purely conventional. The shape which we call "star-shaped "-a term we apply to flowers and other things-is not in the least like a real star as seen by an unprejudiced person. What one really sees is an ill-defined point of light. The pretended conventional star of ancient drawings perhaps arose from the simple artifice of picturing tongue-like flames around or upon any representation of a fire or a source of light- " to show what it was meant to be." Then the notions of perfection and symmetry in regard to the celestial bodies led to the "tongues" being arranged for the purposes of draughtsmanship as perfectly symmetrical-pointed rays of a six-or eight-limbed geometrical design - and latterly it is possible that the mystical figure known as the "pentacle" was 


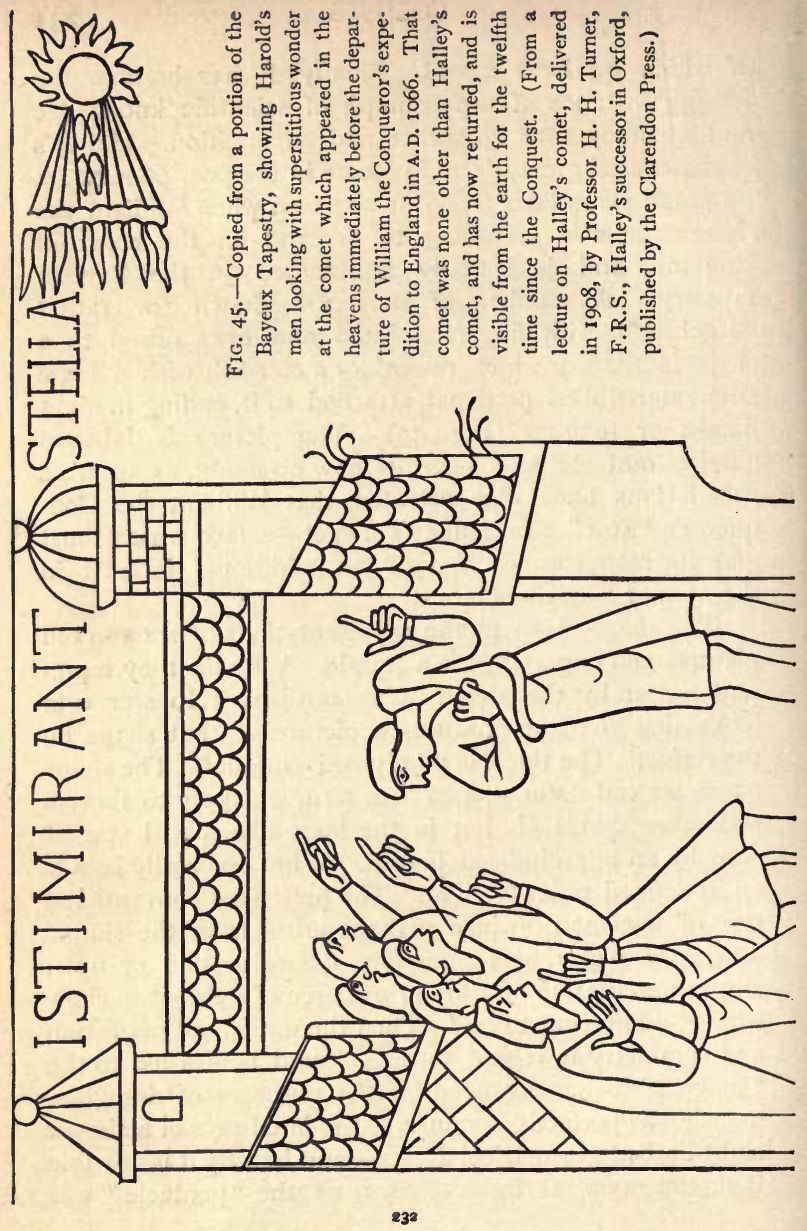


utilised by astrologers and others as the emblem of a star. However they arose, neither the weird and astonishing representations of mediæval times nor the geometrical decorative "stars" of later date seem to have any relation to an attempt to represent a star as it really appears to the human eye and the interpreting brain behind it.

The orbits of comets, says Professor Turner, of Oxford, in a delightful lecture delivered in Dublin in the summer of 1908 , from which I have culled many interesting facts and presented them to my readers, "differ from those of the planets in being far more highly elliptical. Our own path round the sun is nearly a circle, so that our distance from him remains nearly the same all the year round; but the distance of a comet from the sun varies greatly from 'perihelion,' when it is near, and consequently bright, to 'aphelion,' when he is so distant and faint that we lose sight of him." The sun is not at the centre of the ellipse described by a comet's path, but is quite near to one end of it, so that comets approach the sun far more closely than do the planets, some taking so close a turn round the sun that the heat from it to which they are exposed is 2000 times as great as that which the earth receives. If the orbit of a comet is really elliptic, then there at last comes a time, though it may be only after thousands of years, when the comet, having rounded the sun at close quarters, and journeyed off into space; has his journey brought to a turning-point at the other end of the ellipse, and begins to draw near again, advancing towards the sun. The length of the orbit of Halley's comet is about 3255 million miles, and the breadth at its broadest is about 800 million miles, and he takes about thirty-eight years to travel the full length (along the curve) and thirtyeight years to come back again! Other comets have other lengths and breadths of orbit, and take longer or shorter periods to go round. But the conditions of attrac- 
tion affecting a comet may be such that the return journey never occurs. They may be such that the comet goes on indefinitely travelling away from our sun, until he is caught by some other star, and his orbit changes its shape, with the new sun as attracting centre. These are the "wandering comets" as distinct from the "periodic comets," which have been shown to conform to Halley's scheme of their movement and recurrence.

And now some one will ask, perhaps impatiently, "What, after all, is a comet?" We have seen that many are continuously, and others casually, members of the solar system. What do they consist of? Spectrum-analysis shows that they consist chiefly of the chemical element carbon. ${ }^{1}$ Though they have weight, and are attracted by the sun, yet they seem to be for all their size and terrifying shape and glare incredibly light and airy things. Herschell declared that the tail of a big comet probably consisted of but two or three pounds of solid matter-diffused, rarefied, and luminous. And the head or nucleus certainly does not weigh many hundreds of tons. In the eighteenth century astronomers observed a comet pass right in among the moons of the planet Jupiter. You might expect the moons to be terribly knocked about by such an impact.

${ }^{1}$ I am indebted to Mr. Rolston, of the Solar Physics Observatory, South Kensington, for some information on this matter.

Generally speaking, it appears that the spectra of these bodies indicate carbon-in some form-as the principal constituent.

As to the particular form of carbon, there is still a considerable doubt, so much that, in describing the spectrum of Morehouse's comet, Professor Frost says (Astrophysical Journal, xxix., p. 59, I909) :- "We avoid the still unsettled question of the 'carbon' bands (of the so-called 'Swan' spectrum) which have been so often ascribed to a hydrocarbon, specifically acetylene, and we use for them the simple designation 'carbon.'”

In addition to this "carbon" there is the cyanogen spectrum present in most cases.

Sodium and iron have been detected in the spectra of some few 
They were not; they were not deflected in the smallest appreciable degree from their position and regular movement! One is naturally inclined to look upon the tail of a comet as something like the smoke of a railway engine trailing behind the advancing "head." As a matter of fact, it does not always trail behind, but is always turned away from the sun, so that when the comet is travelling away from the sun the tail is in front! It is now held that the tail is caused by the radiant energy (light and heat) of the sun, blowing, as it were, the lighter particles from the incandescent head, and causing them to spread out in a long track of variable shape. The photographs of the third comet of the year 1908 show that the tail can vary to an astonishing extent and with great rapidity -that is to say, in four or five hours. It is seen in those photographs as a scimitar-like curved blade, then with a second head or nucleus behind the leading one, then actually bent like the letter $Z$, and then divided into seven distinct diverging "plumes," and then it returns to its former simple shape-all in the course of a few days. Astronomers have now shown that there is a close connection between comets and the showers of "shooting stars" or meteors which frequently strike the earth's comets, e.g. Wells (1882, ii.), whilst Holmes (1892) showed only continuous spectrum.

An interesting suggestion is made by Newall, namely, that the spectrum is not indicative of the comet's composition, but of that of the medium through which the body passes. Thus the persistent identification of the cyanogen bands in cometary spectra is attributed, primarily, to the "heating up" of cyanogen existing, free, in circumsolar space.

Till 1907 most of the cometary spectrograms showed only the "carbon" and cyanogen radiations, but in Daniel's comet of that year, and in Morehouse's of 1909, other lines were detected for which origins have not, as yet, been found.

Thus, some form of carbon + unknown + (occasionally) sodium and iron seems to sum up our present knowledge of cometary composition. 


\section{SCIENCE FROM AN EASY CHAIR}

atmosphere. It is considered probable that comets eventually break down into streams of meteors, and that their "life" (if one may use that term) is, relatively to that of other heavenly bodies (which-are all undergoing change and, in many cases, decay), not a very long one. But there are no facts at present known which enable us to tell whether a given comet is young or old, and it would have been a decided shock had it been found that Halley's comet, which has so happily spent every seventy-sixth year with us for so many centuries, had "burst up," or by "indisposition" had been unable to pay his usual visit as expected in 1910. 


\section{XXV}

\section{ABOUT CHOLERA}

WHAT is this terrible disease which every few years travels from the banks of the Indian Ganges, where it is always present, and makes its way to one or more of the great cities of Europe, killing its thousands with horrifying rapidity? The word "cholera" is used by the great Greek physician of antiquity, Hippocrates, and by his followers down to the days of our own Sydenham, to describe a malady which occurs commonly in summer, is often of severe character, but rarely fatal, and is characterised by the exudation from the walls of the intestine of copious fluid, usually accompanied by vomiting and sometimes by "cramps." This malady is now distinguished by physicians as "simple cholera," or European cholera, the last name being misleading, since the disease occurs all over the world. It is caused by a special microbe, which multiplies in the intestines and produces a poison. Other microbes produce similar results. One which causes luminosity in foul salt water has been found to produce cholera-like results when cultivated in a state of purity and swallowed by man. Other poisons besides those produced by microbes set up a sort of "cholera" in animals and man. Drugs of both mineral and vegetable origin have this effect, as every one knows, and are used in small quantities to produce 
purging. Microbes which are noted for other obvious effects which they produce by the poisons they form in man's intestines - such as the microbe of typhoid feveralso produce cholera-like purging.

But the name "cholera," or "the cholera," is now applied without any further qualification to what would be more correctly described as "Indian cholera," or "epidemic cholera." It is a disease which first became known to Europeans in India in 1817 , less than a hundred years ago. It resembles "simple" cholera in its general features, but is usually much more violent in its attack, and often causes complete collapse in two or three hours from its onset, and death in as many more. The main point about it is, however, that it is a quickly spreading "epidemic" disease; it invades a whole population, and travels from place to place along definite routes. Although the outbreak of cholera in India in 1817 was the first to attract the attention of Europeans, it was nothing new in India, and was recognised in distant ages by Hindu writers. Its usual name on the delta of the Ganges is "medno-neidan." Ninety per cent. of the population perished of cholera in some districts of India in 1817 , and English troops were attacked by it with terrible results.

Cholera gradually made its way in subsequent years through Persia to Russia, and at last to Western Europe; but it was not until late in the year I831 that Indian cholera arrived for the first time in England, and in the following year it caused something like a panic. There have been at least three subsequent outbursts of Indian cholera (before that of the year 1908) which have reached Europe, and two of these have reached England and caused profound alarm and anxiety. That in 1854 reached us just before the Crimean War, and caused such rapid and numerous deaths in London, especially in the West End (St. James's, Westminster), that the corpses 
were removed in carts as in the days of the plague. It was then that the Broad Street pump became famous, and the carefully demonstrated history of a cesspool leaking into the well of the pump, of the existence of a cholera patient in the house to which the cesspool was attached and of the infection with cholera of healthy people who sent all the way from Hampstead to fetch what they thought was the beautifully pure, cool, and palatable water of Broad Street, St. James's, caused a most vivid and salutary impression on the public mind. The "watercarriage" of the cholera infection was established as a fact, and the subsequent abolition of surface wells and pumps, as well as of cesspools, in London and other cities was the result. Indeed, the active development of sanitation and sanitary measures of all kinds in Great Britain may be traced to the panic caused by the cholera in 1854 and to the well-founded conviction that it was in the power of the community, by the construction of sewers and the provision of untainted water-supply, to protect itself against such disaster in the future.

Years passed by, and still the actual germ of cholera was unknown. In India it was not even admitted that its diffusion was especially connected with water-supply. The methods of observing with the microscope those minute swarming organisms which are called "bacteria" became immensely improved. They were isolated, cultivated in purity, and the activity of a vast number of different kinds of different shapes, sizes, and modes of growth was ascertained. They were distinguished according to their shape as bacilli, spirilla, micrococci, and so on, and separate kinds were characterised-one producing ordinary putrefaction, another the souring of milk, another the "cheesing" of the same fluid, another the destruction of teeth and of bone, another the terrible anthrax of cattle or wool-sorters' disease, another (a 
spiral thread in the blood this !) the recurrent fever of East Europe-each producing its own special poison or other chemical substance.

So it went on till Koch, of Berlin, discovered the bacillus of tubercle and Hansen that of leprosy. Others had failed to find what Koch now found as the result of a special mission on behalf of the German Imperial Government to India (undertaken as nearly as I can recollect about the year 1884 )-namely, the living organism (Fig. 46) which by its growth in man's intestine causes Indian cholera. Koch found a spiral threadlike "bacterium" in cholera patients, which readily breaks up into little curved segments like a comma (each less than the one ten-thousandth of an inch in length), and swarms by the million in the intestines of such patients. He showed that it can be cultivated in dilute gelatinised broth, and obtained in spoonfuls. It was, however, only with great difficulty that he could produce cholera in animals by administering this pure concentrated growth of cholera germs to them.

Then a most courageous thing was done. A great and very acute investigator of cholera in Munich, Pettenkofer by name-who did not believe that Koch's comma-bacillus was really the effective germ of cholera - himself swallowed a whole spoonful-many millionsof the cultivated cholera germ. His assistants did the same-and none of them suffered any ill effect! Few, if any, of the investigators of this question gave up, as a consequence, their conviction that Koch's bacillus was the real and active cause of cholera. They supposed that it must be necessary for the human intestine to be in a favourable condition - an unhealthy condition-for the Koch's bacillus to multiply in it. It was by this time known that bacteria of all kinds are exceedingly sensitive in regard to the acidity or alkalinity, the oxygenation or 
de-oxygenation of the fluids and organic substances in which they can, when exactly suited, multiply with tremendous rapidity. Thus the tubercle bacillus cannot be cultivated on pure blood-serum, but if a trace of glycerine be added to the serum the tubercle bacillus grows, divides, multiplies like yeast in a brewing-vat. A little later Pettenkofer's audacious experiment was repeated by Dr. Metchnikoff in Paris. He swallowed a cultivated mass of the cholera germ on three successive days, and had no injurious result. Others in his laboratory did the same, with the result of only a slight intestinal disturbance. But of a dozen who thus put the matter to the proof in the Institut Pasteur, one individual acquired an attack of true Indian cholera, accompanied by all the most violent symptoms, which very nearly caused his death. This experiment put an end to all discussion, and demonstrated, once for all, that the commabacillus (or spirillum) of Koch is really capable of producing Indian cholera, and is the actual agent of this disease.

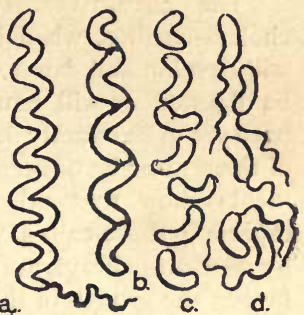

8888 f.

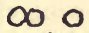

\&.

$\theta$.

FIG. 46.- $a, b, c, d$. The cholera spirillum, or comma-bacillus of Koch; $a$, spirillum stage of growth, with vibrating flagellum, by which it is driven along with screw-like movement; $b$, the spirillum has lost its flagellum, and is motionless : it is marked off into separate seg. ments; $c$, the segments have separated from one another as comma-shaped pieces, hence the name "comma-bacillus" given to it by Koch; $d$, a number o1 comma-bacilli of cholera which have developed tails of vibratile protoplasm (like a single cilium), and are swimming about, being driven by the lashing of these tails; e, a cubical packet of sarcina ; $f$, a double row of the spherical units (cocci or micrococci), which form a sarcina-packet; $g$, similar cocci separated. 
The circumstances which determine whether the cholera-bacillus, when it gets into the human intestine, will develop and cause an attack of cholera, or will simply be digested or will remain alive, but inactive, for a time, have yet to be exactly determined. Obviously a knowledge of them must be of immense importance. Certain experiments show that other minute parasitic organismsespecially those called Sarcina (Fig. 46,e), which often, but by no means always, are abundant in the human intestinefavour the growth of the cholera-bacillus-in fact, prepare the ground or soil, as we may call it, for that deadly organism. This has been shown experimentally by sowing cholera-bacillus on plates of slightly acid gelatine, or jelly. It will not grow on this, but if at certain points on the surface of the jelly the Sarcina organism is planted, then it is found that all around the points where the Sarcina is growing the cholera-bacillus also flourishes and multiplies. And it seems probable that, just as there are microbes which are adjuvant or helpful to the cholera microbe, so there are others which are repressive or destructive of it. We know that this is the case with regard to some other microbes-namely, that a microbe which will flourish abundantly on a prepared jelly if it is alone, is entirely repressed and arrested in its growth by the presence of one other ascertained kind. It is, in fact, thus that some of the commoner putrefactive kinds of microbes occurring in river water are repressive of the typhoid-bacillus, which, if it should get there, flourishes best in the purest water or in water containing no other microbe. There is some ground for thinking that in certain districts there may be microbes present which make their way into the human intestine, and then actually repress the cholera-bacillus, should it subsequently be taken in with food or water. It would, of course, be of immense importance to discover such a microbe, if it 
exist, and the inquiry is at the present moment proceeding in Paris.

A very striking and at first sight astonishing fact in regard to this subject is that there are a very large number and variety of microbes habitually present in the human digestive tract. There are so many different kinds -differing altogether from one another in their chemical action-which are present in greater or less abundance in this tract from one end to the other, that no one is at present able to say even approximately how many there are, nor to give anything like a complete account of their properties. The fact is that their isolation and study, and the definite determination of their properties, is not an easy job. Many workers are engaged on it, and it will be years before the matter is threshed out. One most curious result of these studies is that a person may have the cholera-bacillus in his intestine-not growing with any activity, but still alive-and yet be perfectly well. He can, therefore, carry the cholera-bacillus from one locality to another and spread the disease, and yet be entirely devoid of suspicion, free himself from disease, and certified as healthy! The same is true of the bacillus of typhoid fever. Persons who have had typhoid fever have been shown to retain the typhoid-bacillus flourishing for as long as fourteen years afterwards in their intestine, without any ill effects to themselves, and to have been the constant source of infection and disease to those living in the same house with them by spreading the bacillus. The classical case of this is that of a woman who carried on a baker's business at Strasburg. Infection by and protection from microbes is by no means so simple a thing as it is sometimes represented to be.

Now that we are quite sure as to Koch's comma-bacillus, or spirillum, being the definite poison-producing agent causing Indian cholera, it is comparatively easy to under- 
stand its mode of dispersal and infection, and consequently how to avoid its attack. It is cultivated in the laboratories devoted to the study of such matters-kept in confinement, so to speak, for ten years and more-and its properties and conditions of life are well known. For instance, it is destroyed by "dryness," hence it cannot be carried in a living infective state as "dust" in the air. It is also destroyed by exposure to a heat a good deal below that of boiling water, so that water itself can be freed from it by boiling, and food dipped in boiling (or nearly boiling) water, or heated on a metal tray beneath which a spirit or gas flame is burning, can be rendered safe just before it is swallowed, even when cholera is rife in the neighbourhood. Ordinary lime is a great destroyer of the bacillus, and can be used on a large scale to abolish it in refuse.

When the cholera is near one cannot be too scrupulously clean. The fingers must be carefully washed with antiseptic before a meal, and everything purified by heat only a few moments before being put into the mouth, since flies and careless handling may soil food or anything else exposed in a cool condition even for a few minutes. It is best when cholera is actually present in the house or town in which you live to swallow nothing which has been allowed to get cool; everything should be heated and eaten when hot. Mephistopheles, in Goethe's Faust, complains of the swarming, pullulating life on the earth. $\mathrm{He}$ - the great destroyer-says :

"How many have I sent to grass!

Yet young, fresh blood, do what I will

Keeps ever circulating still.

In water, in the earth, in air,

In wet, dry, cold-everywhere

Germs without number are unfurl'd,

And but for fire, and fire alone,

There would be nothing in the world

That I could truly call my own." 
The version is Sir Theodore Martin's. Mephistopheles might be a bacteriologist explaining the difficulty of dealing with disease germs. In any case, it is the Mephistophelian spirit of annihilation, and flame as its instrument, which man brings to his service in the contest with cholera germs.

The great carriers of cholera are human beings themselves travelling in caravans, pilgrimages, shiploads. For the fact has now been established that a man may harbour inside him the cholera-bacillus without its multiplying largely or rendering him seriously ill. Once it is brought by such an individual into a favourable locality, it is spread by water contaminated by him, and yet used for drink and domestic purposes; and also it is spread by his touching things in which the bacillus can grow, such as cooked food, fruits, etc., swallowed subsequently by unsuspecting purchasers or employers. You have, in order to avoid cholera (and similar infections), not only to have very clean fingers yourself, but to see to it that your servants' fingers are clean also, or else that anything they touch is afterwards heated for a few minutes to near boiling-point before you let it enter your mouth. A little history illustrative of the need of this precaution is on record. In Egypt during a recent outbreak of cholera there was a very wealthy lady who lived alone in an isolated palace under the charge of a physician. She had a delicate appetite; her food was most carefully prepared. She drank and used only boiled sterilised water; no one was allowed to approach her except her servants, who never left the palace grounds, and were in good health. She sickened of cholera and died. It was a puzzle as to how she had acquired the infection. Her physician at last discovered that she daily partook of cold chicken-broth, prepared carefully by her cook. The cook, though practically well, was found to be infected with the 
cholera-bacillus, which had probably lodged in his intestine some weeks previously at the commencement of the outbreak of the disease in Egypt. Though living in him the cholera-bacilli had not found a favourable field of growth. This man in handling the cold broth, the cloth used to rub the spoon with which it was stirred, or the basin itself, had, it was found by making the actual experiment, been able to transfer the minute bacillus to the cold broth, a most favourable and nourishing medium for its growth, and so his isolated carefully guarded employer received an abundant crop of the bacilli and developed a fatal attack of cholera. Had the lady taken the broth hot, there would have been no living cholera-bacillus in it, and if she had thus guarded herself in regard to all food, by the use of heat and great cleanliness, she would have escaped infection.

The most interesting development of knowledge and speculation with regard to the microbes which infest the human intestine and other regions of the human body is (as I mentioned above) connected with the fact that one kind or species of microbe has the power of favouring the growth of another, if present alongside of it, and that another kind has the power of checking or antagonising its growth. Thus common putrefactive microbes of river water are hostile to the cholera-bacillus and to the typhoidbacillus. Those disease-producing bacilli live longest and best in very pure water! Thus, too, it is found that the microbe of sour milk-the lactic-bacillus-is antagonistic to the common putrefactive microbe of the intestinal contents-the well-known bacillus coli. In virtue of the acid which it produces, the microbe of sour milk arrests the excessive growth and activity of the putrefactive bacillus coli. Hence the utility of sour milk in many cases of intestinal trouble. We contain within us a microbian flora of such variety and abundance of kinds and so nicely balanced 
in their antagonisms and co-operations in a healthy man, that one cannot wonder at the timidity of the medical man who hesitates to interfere with their conflicts and established modus vivendi. Yet that seems to be the direction in which action will have to be taken. It seems likely that in different localities-towns, forests, highlands, lowlands, seaboards-there are prevalent different microbes which enter the bodies of human visitors and act as disturbers of the native microbian flora previously established in the stranger.

That there are great differences in the microbian flora (including herein minute moulds and fungi as well as bacteria) of different localities, is shown by the great experiment of cheese-making which mankind carries on. Each kind of cheese-Stilton, Cheshire, Dutch, Roquefort, Gruyère, Gorgonzola, etc.-is the result of the combined and successive action on milk of a vast number of microbes ; and it is the fact that the combination which produces any given kind of cheese is only found and (unconsciously of the exact nature of what he is doing) brought into activity by man at certain places. You cannot make Cheshire cheese in France nor Gruyère in Cheshire, and so on. It is suggested-and the matter is being pursued by experiment and observation at the present time in Francethat possibly amongst the other things which go to make up the qualities of the air which agrees or disagrees with one in any given locality-are the local microbes. This must not be regarded as a conclusion which has been fully worked out-it is an ingenious and promising suggestion made by Metchnikoff as the result of some observations, and will be fully inquired into. The fact which I have mentioned above (p. 242) - that the presence of the microbe Sarcina favours the growth of the cholera-bacillus-indeed, enabling it to grow and flourish in conditions in which it was inert until the Sarcina was "sown" alongside of it- 
renders it worth investigating the question as to whether there are "local" germs or microbes which in this or that region are abundant and get into man's food and drink, and so into his intestine, and become established there, helping or antagonising the growth of other microbes already there or subsequently introduced. Thus, to the various considerations in regard to the "air" of a locality, such as rarefaction, moisture, temperature, movement, ozone, and the perfumes and exhalations of pine trees, rosemary, and sweet-smelling grasses, which seem to be those which are the most likely to affect the health of inhabitants and visitors, it is not improbable that we must add the influence of an invisible local flora of microbes. The inquiry is a long and laborious one, but it will be carried through. The microbes, whether in air or water, or on the surfaces of things, can be collected by washing them into warm liquid gelatine. Then the gelatine is poured out on a plate, and hardens as a thin sheet of jelly. This is protected from all further contamination, and, after a few hours, each invisible microbe embedded immovably in the jelly makes itself apparent. It multiplies enormously whilst remaining stuck to one spot, and is no longer invisible, but presents itself to the eye as a little sphere, or disc, of characteristic shape, colour, and quality, consisting of many hundred thousands of crowded microbes produced by the growth and division of the original invisible one. Some dozens or some hundreds of little growing "dots," and of many various kinds, will thus reveal themselves in the jelly according to the number and kinds of utterly invisible parent microbes introduced by your "washings" into the jelly. And so the investigator has the means of getting at each kind of invisible microbe quite detached from the others, and of separating it for further cultivation and experiment as to its chemical and disease-producing qualities. These microbial gardens of 
jelly-plates are, indeed, a wonderful revelation and a fitting "horticultural" accompaniment to the dark and gloomy forests of rampant wild microbes in our insides, where all are struggling for the soil, one crushing out another by its sheer exuberance, a third choked by the encircling luxuriance of a fourth, just as the trees, mosses, and climbers of a tropical jungle are budding, pushing, grasping, destroying one another in their irrepressible growth.

Pettenkofer, of Munich, when he found (as Metchnikoff did later) that the cholera-bacillus could be swallowed in spoonfuls without producing any harm, came to the conclusion that, though it was a necessary agent of the disease "cholera," yet that there was still an unknown additional determining "cause" of a local character which must be present in order to render the "cholera-bacillus" effective. Metchnikoff is now seeking this "local" cause and parallel antagonistic causes, in the microbian flora of localities which locally effect an entry into the human body, and are, on the one hand, "favourable," or on the other hand "antagonistic." Take as a concrete example Versailles. When cholera has been rife in Paris, there has been no cholera at Versailles. There is something at or about Versailles which does not permit cholera to flourish in men who live there. The guess-the hypothesis-which is being investigated at this moment, is that there is possibly a microbe present at Versailles which enters into the microbial jungle of the intestine of mankind there, and is inimical to, repressive of, the cholera-bacillus when it also arrives there. Similarly, the suggestion is entertained, and is being experimentally tested, that there is in Paris a microbial inhabitant of the intestine which is favourable to the energetic growth of the cholera-bacillus when it puts in an appearance, but that this favouring (as yet undetermined) microbe does not exist at Versailles. 


\section{SCIENCE FROM AN EASY CHAIR}

These imaginings and guesses as to favouring and antagonising microbes must not be confused with the definitely ascertained facts as to the cholera-bacillus. But they are quite sufficiently important and probable to justify their narration to a discreet and sympathetic public. 


\section{XXVI}

\section{SEA-BREEZES, MOUNTAIN AIR, AND OZONE}

GIFTY years ago people were very fond of talking F about "ozone," and the word is popularly used nowadays to signify a mysterious attribute of the air of the sea-coast or moorland without its real significance being generally understood. When Sir Oliver Lodge the other day warned people against hurting their nasal passages by sniffing up an unduly strong dose of ozone produced by a special ozone-making apparatus, I am inclined to think that most people who read what he said wondered what "ozone" might be.

In the eighteenth century it was noticed that the sparks from a frictional electrical machine are accompanied by a peculiar pungent smell in the air. Many years after that, namely in 1840 , the great chemical experimenter, Schönbein, the friend and correspondent of Faraday and discoverer of gun-cotton, found that the smell in question is produced by a special gas, which is formed in the air when electric discharges take place. He found that this gas was a powerful oxydiser-would, in fact, oxydise iodide of potassium so as to set free iodine-and thus its presence could be detected by means of paper slips coated with a mixture of starch and iodide of potassium. When they were exposed in air which contained even minute traces of this strange gas they became purple-blue, 
owing to the liberation of iodine and the formation of its well-known blue combination with the starch. Schönbein found that in breezy, fresh places his test-papers turned blue, and concluded from that (confirmed by other evidence) that this smelling gas, to which he gave the name ozonewhich simply means "the smelling stuff"-is present in good, ordinary atmospheric air, as well as in artificially "electrified" air. It is destroyed when such air is heated above the boiling-point of water, and seems to be, as it were, "taken out" of the air by all sorts of dead organic matter, so that it is not present in the air of large cities. I remember that when I was a boy we used to test the air for ozone with Schönbein's papers (I am aware that their colour change is not absolute proof of the presence of ozone, as other oxydising gases might, if present, act in the same way), and we used to find more ozone when a south-west wind was blowing than in a north-easter!

Schönbein wrote sixty papers on ozone-but its real nature was made out by others who succeeded him, chiefly by Andrews, of Belfast, and Tait, of Edinburgh. It turns out that ozone is a condensed form of the elemental gas oxygen-squeezed, as it were, and literally "intensified," so that three measures of oxygen gas become only two of ozone. It very readily changes back againtwo measures of ozone expanding to form three of oxygen. It is produced by the action of an electric discharge upon oxygen gas driven over the discharge and in greatest quantity when that kind of gently-buzzing electric spark which is called "the silent discharge" is used. It can be produced in quantity by passing atmospheric air, or better, pure dry oxygen gas through a glass tube in which such a silent discharge is made to take place. As much as seventeen parts in a hundred of the gas can be thus converted into "ozone," and some twenty years ago two French chemists succeeded in getting even a larger proportion, 


\section{SEA-BREEZES, MOUNTAIN AIR, AND OZONE 253}

and by submitting it to a tremendous pressure at a temperature of 100 degrees below the freezing-point of water, they obtained pure ozone as a transparent liquid. It was of a dark indigo-blue colour, and somewhat dangerous and explosive when the pressure under which it had formed was removed. Ordinary oxygen gas has since then been also liquefied in the laboratory: it is of a paler blue colour.

The "smell" which old writers had noticed and Schönbein had named was thus actually obtained as a distinct blue liquid. It is this which, though present only in minute quantities, gives special oxydising activity to fresh air. When pure, or present even to the small extent of 4 per cent. in air, ozone is a destructive agent, a sort of extra-quality oxygen of triple instead of double power. Indiarubber is rotted and destroyed by it in a few minutes-a sort of combustion or quick oxydation taking place-and it is, of course, dangerous to the softer parts of the human body, such as the air passages and lungs and the eyes-when present in more than a minimal proportion. I believe that no one has yet determined exactly how great a percentage of ozone can be tolerated by a human being in the air taken into the lungs. In ordinary fresh country or sea-coast air only one part by measure in 700,000 has been found to be ozone, that is, $\frac{x}{7000}$ per cent. But it is quite likely that much more is occasionally present, since it is very difficult to arrange a satisfactory examination of the air of any locality so as to determine how much ozone it contains. It is said that at higher levels the atmosphere contains more ozone than it does at lower levels.

It is not to be wondered at that ozone should thus have attracted general attention and interest as the distinctive and specially active agent present in the pure air of the sea-coast and the mountain-top. People not 
infrequently, on arriving at the seaside, sniff up the odours of decomposing seaweed (containing a little iodine), and think they are smelling the "ozone." It is doubtful whether enough ozone is ever present in the atmosphere under simple natural conditions to affect even a highlysensitive nose. But it is easy to produce enough by passing air over a silent electrical discharge to fill a large room with its peculiar smell. Whether it really is of benefit to the human being who inhales a properly limited percentage of it seems not to have been clearly decided by experiment, although both in London and the United States of America there are enterprising medical men who are convinced of its value and are using it. It would certainly seem that if the peculiar benefit which is often derived from sea air or from mountain air is due to the presence of this extra oxygen in such air, then nothing can be simpler or more rational than to introduce the proper and useful percentage of ozone into the air of specially-arranged chambers in London and other large towns, so that we can visit or even inhabit them and breathe ozonised air at will without going on a journey for it.

But it is a remarkable fact that, as with various natural so-called "mineral waters," so with various "airs" which people find beneficial-no one has yet clearly and decisively shown, in the first place, whether they exert any chemical effect of a special kind on the people who seem to benefit by drinking the one or breathing the other; still less has any one shown what is the particular chemical ingredient of the air or of the water of any given resort which exerts the beneficial effect attributed to that air or that water.

The air in different localities differs most obviously and importantly in four particulars, namely, as to whether it is still or windy, whether it is cool or hot relatively to 
the local surface, whether it is heavy or rarefied, whether it is dry or saturated with moisture. It is also an important fact that the atmosphere consists of layers and currents differing in these qualities, and that the higher layers can be reached by ascending to high-lying lands. At the same time it seems that in a flat country the ascent of a comparatively low hill brings you into a layer or "stratum" of air differing more from that of the plain or valley than would be the case were you to ascend to the same height in a mountainous region. The seaside and the mountain may owe the beneficial character of their air to some of the varying qualities noted above. Chemical differences may or may not be important, and seem hardly to have been as yet brought within the range of accurate knowledge. Ozone may be more or less present, so may perfumes and volatile oils, such as are given off by pine trees, and there may be more or less minute quantities of carbonic acid and of sulphurous acid, and still minuter quantities of the newly-discovered gases -argon and helium-which, for all we know, may have some effect on the human body. There seems to be a great field open for accurate investigations in regard to the action upon human health of all these varying conditions of the air. In the meantime, we proceed by guesswork, and are influenced by tradition and beliefs which are based on a sort of experience, but are of a very vague and unsatisfactory description.

The case is much the same with regard to the natural waters of celebrated resorts. So far as their chemical composition is known, they can be manufactured and applied for drinking or bathing anywhere. But minute quantities of certain gases and other elements may be present in these natural waters and have escaped until now the observation of the chemist, and it is possible, though not demonstrated, that these rare chemical con- 
stituents may have some action on those who drink or bathe in the water. Ever since the time of the Romans natural mineral waters have been sought, and the springs which discharge them have been frequented, not because their chemical composition was known, but because experience seemed to show that they produced a beneficial result. It can hardly be doubted that the baths and springs frequented at the present day are not so much themselves the cause of the benefit to the cure-seekers as are the change of scene and diet, and the repose and regular life willingly accepted by those who travel so far to reach these springs.

With regard to ozone, there remains something more to be said, namely, in regard to its application, in a far less diluted form than is possible when it is taken into the lungs, to the destruction of putrefying organic matter and putrefactive and disease-producing bacteria. It is now some five or six years since air containing a high percentage of ozone-produced by the action of the electric discharge-was used for the purification of the water-supply of large towns. It is a fact that river water into which such ozone containing air is pumped becomes pure in the highest degree, in consequence of the destruction by the ozone's oxydising action, both of the bacterial germs always present in vast numbers in river water and of the organic matter on which the bacteria depend. This application of ozone is in use in several large towns for the purification of drinking-water, for which purpose it has very great advantages. It has also been successfully used by Dr. Allen, the director of the Plymouth Marine Laboratory, for keeping the water of the marine aquarium there in a state of purity and well charged with oxygen gas. A similar use has been made of oxygen containing a considerable percentage of ozone by enterprising surgeons for the cleansing of ulcer and abscess. It is clear that such 
a gas may present mechanical advantages over any liquid application.

Ozone is not, apparently, in favour or fashion with the general body of medical practitioners at the present day but possibly further examination and determination of its physiological properties may lead to its receiving more attention in medicine. Already the peroxide of hydrogen -which is more or less correctly described as "ozonised water," and is used (under the name "Auricomous hairwash") to change dark hair by its oxydising action to a golden tint-is used by surgeons for washing out purulent wounds and abscess. Those who use the gas itself only go a step further. Some day we may see a more general use of ozone; on the other hand, it remains to be seen by direct and accurate experiment whether its properties are as valuable to man as we may hope they will prove to be. 


\section{XXVII}

\section{OXYGEN GAS FOR ATHLETES AND OTHERS}

CINCE the preceding chapter on ozone was written 5 I have learned that this peculiar triple-condensed variety of oxygen (it is called by chemists " $\mathrm{O}_{3}$ " whereas ordinary oxygen is " $\mathrm{O}_{2}$ ") is now being most successfully applied to the purification of the watersupply of several large cities. A notable case is that of the great winter resort, Nice. Ozone gas is one of the most effective destroyers of organic impurity known; it destroys both bacterial germs and the putrescible impurities of water completely, and is itself converted in the process into harmless health-giving oxygen, whilst the water is rendered absolutely free of all germs. It is readily manufactured by treating oxygen with the electric discharge, and is produced at a cost which renders its use in water-purification an economical and financially satisfactory method. The use of ozone gas as a medicinal application to cavities in the living body in which disease-producing bacteria are lodged is making progress. It has to be administered with great care by a medical expert, and though there has been delay and opposition on account of the novelty of the treatment, there are signs that ozone will become established as a valuable therapeutic agent. It is a singular fact that so little has been done of late by scientific observers either 
as to the presence of ozone in the atmosphere or as to the action of ozone on the healthy animal body when present in minute quantity in the air taken into the lungs. The general opinion appears to be that it is either altogether absent from the atmosphere or present only in quantity so minute as to be negligible from the point of view of the physiologist except in very high mountain regions, and there the exact quantity remains undetermined. The only experiments in the last ten years on the subject of its action on animals are some which led the inquirers to the conclusion that constant exposure (in a closed chamber) to an atmosphere containing 4 per cent. of ozone caused death after five or six days by an inflammation of the lungs. Clearly it is desirable that further investigation on this subject by competent authorities should be made, and the effect of smaller quantities of ozone in the air respired, whether continuously or at intervals, should be ascertained.

The action of ordinary oxygen gas is a separate matter. The atmosphere which we breathe consists of one part by volume of this gas and of four parts of nitrogen gas. It is the oxygen which is necessary to us and to all animals, and the nitrogen is merely an inert diluting accompaniment of the essential oxygen gas. It is, of course, easy to increase or to diminish the proportion of oxygen in the air breathed accordingly as one introduces additional pure oxygen or, on the other hand, diluting nitrogen into a collapsible bag or sac from which one continuously draws breath. Such a bag can be connected by a tube to a helmet or mask enveloping the head. The expired air is discharged by a specially provided passage. It used to be thought that it was dangerous to breathe pure undiluted oxygen, although the proportion of oxygen to nitrogen in the air taken into the lungs might be increased to as much as a half 
without injury, and, indeed, with great benefit in some serious conditions of collapse. Dr. Leonard Hill, F.R.S., of the London Hospital Medical College, has, however, recently shown that oxygen gas, of 97 per cent. purity, may be breathed continuously for as much as two hours without any ill-effects or sense of inconvenience. Contrary to what has been stated, it is neither exciting nor unpleasant. He has made the experiment on himself and on some of his assistants, and in doing so has made use of such an apparatus as that abovementioned-so as to ensure the in-take of undiluted oxygen.

Dr. Hill and Mr. Martin Flack have further found that the exhaustion and labouring of the heart which is brought on by such special exertion as that involved in running a hundred yards race or a quarter-mile race, is almost completely avoided if the runner "fills his lungs" with oxygen gas before starting. The runner takes the oxygen gas into the lungs for some two or three minutes before starting to race; of course, the lungs are not thus actually "filled" with oxygen, but a much larger proportion of that gas is lodged in them than when ordinary air is breathed, and a full supply is thus afforded to the blood. The "distress" caused by violent athletic efforts appears to be entirely due to the using up of the available oxygen by the unusual activity of the muscles. The heart itself suffers most, the breathing becomes laboured, and there is a sense of suffocation, due simply to the urgent demand by the blood, heart and muscles for more oxygen. If, therefore, we ensure that there is an extra supply of pure oxygen in the lungs before the unusual effort is made, we avert these distressing symptoms: the unusual quantity of oxygen needed is ready for use. Dr. Hill himself and young men who have tried the plan of inspiration of oxygen before a 
foot-race, declare that they cannot believe that they are really running hard, even when surpassing their usual performance. They come in at the end of the quartermile, having beaten their record; and with no sense of having made a special effort; they feel fresh and ready to start again after more oxygen and a short rest. Moreover, the after-effect on the muscles is stated to be such that "stiffness" and what is called "grogginess" (due in ordinary circumstances to the retention of lactic acid in the muscle) do not supervene.

Swimming and diving, as one would expect, are greatly affected by the preliminary oxygen inhalation; the length of time during which submersion can be endured without discomfort is doubled, and the great effort of fast swimming rendered less rapidly exhausting. Cycling uphill at a rapid pace becomes, according to Dr. Hill's own frequent experience, possible after oxygen inhalation when in ordinary conditions it was impossible. Hockey players and boxers he has found notably benefited by oxygen given both in the intervals of and after the exercise. It is, of course, to be expected that a wider practical application should be made of this simple method of increasing our power of sustaining muscular effort, and of enduring submersion. Dr. Hill suggests that the divers of the Mediterranean, who, without any apparatus, plunge into the shallow sea and remain below long enough to find, cut, and bring to the surface the valuable sponges of commerce, might use the method of preliminary inhalation of pure oxygen gas. $\mathrm{He}$ has also tried the method with a young racehorse, but owing to the fact that the course run was only a mile, and the animal perfectly fit and strong, he tells me that no advantage was found to result from the inhalation. With an older cart-horse somewhat tired by a day's workhe obtained the most satisfactory results, the animal 
becoming obviously recuperated and working without distress.

The question has been raised as to whether the administration of oxygen gas to a man or to a horse when about to run a race should be considered as "doping." It may perhaps be objected to by sportsmen, as involving the provision of special apparatus which all competitors would not be equally able to secure. But it is not "doping," since that applies to the use of a drug, which, whilst exciting to violent effort, produces an injurious after-effect. Oxygen is not in this category; to take an extra quantity of oxygen into the lungs before starting on a race is no more unnatural or risky than to take an extra drink of water into the stomach or to swallow meat extract and such special preparations before or during a race. It would be interesting to see whether a runner in the Marathon race would (as Dr. Hill would expect) be greatly assisted if his trainer carried with him a supply of pure oxygen, and from time to time refreshed him with it. Football players might also be given oxygen at half-time; an oxygenated team would, one surmises, beat its uninspired competitors. A Fife team is reported to have done so. On the roads favoured by cyclists one may expect hereafter to find at the bottom of a long ascent hawkers of "breaths of oxygen" provided with gas-bags and calling out "Buy the lady a breff, sir!" It is, perhaps, worth noting that the relief afforded by oxygen-breathing is no less definite when the gas is taken immediately after a race or sustained effort than when used as a preliminary. The excess of choke-gas or carbonic acid formed during great muscular effort is not the principal cause of the distress experienced. That gas is thrown off by increased expiration. It is the using up of the oxygen and the insufficiency of the supply in the atmospheric air inspired that causes, under 
these circumstances, giddiness, exhaustion, and often collapse.

The difficulty in breathing and the prostration experienced by many people in mountain-climbing is largely due, not merely to the muscular effort of climbing, but to the fact that the rarefied atmosphere at heights of $8000 \mathrm{ft}$. to $15,000 \mathrm{ft}$. and more gives into the lungs in every inspiration but a fraction of the oxygen which is inspired at low levels, and moreover, owing to the low pressure, much less is held in the blood. Even when conveyed by mule, cog-rail, or balloon to these heights-and, therefore, without muscular exertion, sensitive people suffer severely from temporary "oxygen-starvation." They as well as the laborious mountaineer could be saved from all such inconvenience by the use of a skilfully-constructed "traveller's flask" of oxygen gas.

The observations and experiments as to the possible use of pure oxygen by athletes suggest that we might all benefit by occasional if not frequent use of such an atmosphere. Indeed, there are some individuals-amongst others a well-known and distinguished actor-who before making some special effort, or even when feeling tired and unequal to their daily work, inhale under medical supervision a certain quantity of oxygen gas. It would certainly seem that since country air, sea air, and mountain air are useful and refreshing, an artificial supply of extra oxygen might be inhaled in London, either in one's own house or in establishments provided for the purpose, with definite benefit to health, especially if the inhalation were combined with exercise.

The experiments made by Dr. Hill have come about in connection with work undertaken for the purpose of improving the diving and life-saving apparatus named after its inventor, Fleuss. This invention consists essentially in a water-tight helmet and jacket connected with a 
cylinder of compressed oxygen gas which is carried by the diver. The advantage of such an arrangement is that the diver is free from pumping apparatus and can go where an ordinary diver could not. Mr. Fleuss was able, by diving with this apparatus, to prevent an immense loss of property by arresting the flooding of the Severn tunnel which was imminent during its construction. A difficulty in regard to the Fleuss apparatus has been that oxygen gas is a poison, causing inflammation of the lungs and convulsions when under a pressure of from two to three atmospheres-that is to say, at from $30 \mathrm{ft}$. to $60 \mathrm{ft}$. depth in water. The pressure exercised by the air of the atmosphere at sea-level is equal to that exercised by a column of water $30 \mathrm{ft}$. high, and hence at $30 \mathrm{ft}$. depth in the sea the oxygen gas would be under the pressure both of the atmosphere itself and of water to the same amountwhich is expressed by saying that it is under two atmospheres' pressure, or twice the atmosphere's pressure. The pressure of the atmosphere is, in plain figures, $15 \mathrm{lb}$. on every square inch of surface. Of course, the oxygen is compressed far beyond this point in the cylinders in which it is carried. In using it, it is allowed to escape by opening a valve leading into an elastic sac, and is then and there subject to the pressure depending on the depth of water to which the diver has descended. It is found to be dangerous for a diver with this apparatus to descend to a depth of more than $30 \mathrm{ft}$. having pure oxygen in his apparatus, because the oxygen is then compressed under a pressure of two atmospheres. Accordingly, Dr. Haldane, of Oxford, has proposed that the oxygen should be diluted with atmospheric air, so as to give a mixture of equal volumes of oxygen and nitrogen. With this mixture the diver can safely descend to a depth of $60 \mathrm{ft}$. The apparatus is provided with a partition containing caustic soda, which absorbs the carbonic gas thrown out 
of the lungs in expiration. With such an apparatus a diver can safely remain under water at a depth of $60 \mathrm{ft}$., and walk about and explore for as long as two hours. A most important application of this self-contained diving apparatus is found in its use in the exploration of mines, where smoke or gaseous products resulting from an explosion render it impossible for rescue parties to penetrate without its use. It has been the means of saving many lives in such circumstances. A form of this apparatus is made in which the oxygen is supplied, not by a cylinder of compressed gas, but by granules of a chemical compound called pneumatogen, a peroxide of sodium and potassium, which when breathed into absorbs carbonic acid from the air expired by the lungs, and gives off pure oxygen. Submarine ships are now being provided with a dress or outfit of this description for each member of the crew, so that in the case of the entrance of water into the submarine, every man can put on his "oxygen helmet," and one by one, when the ship is full of water, they can pass out by the conning tower and float to the surface. The perfected diving dress, with self-contained diluted oxygen supply and other improvements, has been constructed by Siebe, Gorman, and Co., and was exhibited by Dr. Leonard Hill at a soiree of the Royal Society. 


\section{XXVIII}

\section{SPARROWS, TROU'T, AND SELECTIVE BREEDING}

$\mathrm{HE}$ talk about the urgent need for the destruction
of sparrows reminds me that the word "sparrow" is applied commonly in this country to at least two very different but common birds. No doubt farmers and gardeners know well enough the house-sparrow (Passer domesticus or Fringilla domestica of Linnæus), which is the one they consider injurious. But some boys and some newly-fledged proprietors of country places may inadvertently confuse the house-sparrow with a very different bird, though only a little smaller and of a general brown colouring, also called "sparrow," namely, the hedge-sparrow (Accentor modularis).

The hedge-sparrow is a true denizen of the country. It does not live on grain, but on insects and grubs, and is useful on that account to agriculturists. Its eggs are pure blue. A spotted egg of a cuckoo laid amongst them readily catches the eye, so that cuckoos' eggs are often found in hedge-sparrows' nests. It seems that it is all a mistake on the part of the cuckoo hen when this occurs. The strain of cuckoos properly attached to hedge-sparrows lay a beautiful blue egg differing only in its somewhat larger size from those of the hedge-sparrow itself, and hence difficult to detect. These blue cuckoo-eggs-proper 
to cuckoos which make use of the hedge-sparrow as fostermother-escape detection both by boys and the fosterparents, and successfully hatch out and propagate the race of blue-egged cuckoos with a memory and a sense of smell which bring them back if they are hen-birds to the little hedge-sparrow's nest when they are grown up and have an egg to dispose of. The spotted grey or brownish eggs are, if not discovered by boys, ejected (there is reason to believe) by the hedge-sparrows themselves. They were deposited by mistake by some pippet-loving or warblerseeking strain of cuckoo in a hurry, or are throw-backs to a common ancestral colouring of the egg due, perhaps, to the male parent not being of the true blue strain. A very fine series of "clutches" and nests of hedge-sparrow, robin, shrike, reed-warbler, pippet, yellow-hammer, and other birds with the accompanying cuckoo's egg may be seen in the Natural History Museum, and they show how closely the parasitic egg often resembles that of the fosterparent, though striking failures also occur.

The hedge-sparrow is placed in that group of small birds which includes the robin, the thrushes, and the warblers; it is not a finch. On the other hand, the house-sparrow is a finch, allied to the chaffinch, the goldfinch, and the brambling. It has, like all the finches, a very powerful broad-based beak, and is more than a match for bigger birds than itself. It is really a parasite or "commensal" (messmate) of man, living and flourishing entirely by helping itself to the grain and the young buds of shrubs grown by man, and in towns to the waste fragments of his food and the grain left in horse-dung. Whether it does any good in the early part of the year by eating grubs seems to be doubtful, but the conclusion is justified that it does more harm than good, especially as it drives away other small birds which are exclusively insectivorous. It has gone with European man to all 
temperate climates. There are Spanish, African, Italian and Indian species, closely related to the common housesparrow, which I should like to see put out side by side with it and some of its varieties for the public edification in the Natural History Museum. These are the true "sparrows," and should be compared side by side with the hedge-sparrow, and the differences pointed out.

There is another true sparrow in England, called the "tree-sparrow," which is not nearly so common as the house-sparrow. They are, however, so closely allied to one another that hybrids have been produced between the two. On the other hand, the hedge-sparrow is a great deal too remote from the finches to interbreed with the house-sparrow or any other of the finch group.

There ought to be a careful report on the probable effects, in every direction, of a great destruction of housesparrows before any very drastic measures are taken in that direction. The employers of gamekeepers should remember that by destroying owls, hawks, and weasels they may not only enable small injurious birds to flourish in excess, but that they may encourage disease and weakness in the game-birds which they so eagerly desire to multiply, since the natural extermination of weakly birds by birds and animals of prey is put an end to when the latter are abolished. In all such matters more knowledge is needed, and reasonable people will not take irretrievable action until they have taken the trouble to obtain thorough knowledge.

It is a curious fact that though the house-sparrow does not naturally sing, yet hand-reared house-sparrows have been made, by association with bull-finches, to acquire the song of that bird-a truly astonishing instance of hidden or latent capacity.

A lover of trout-fishing has been writing lately upon the question as to whether the trout in much-fished rivers 
and lakes do or do not exhibit increased "wariness," or even "intelligent caution" in avoiding the flies so cunningly thrown before or above them by the skilful angler. It is argued that there cannot really be any increased indisposition of trout to take the fly based on experience, because on an estimate of the number of trout in a river like the Test, and of the limited number of anglers, every fisherman would have to hook and lose some thousands of fish every year for the experience to be general among trout that the horrid artificial flies "hide a still more horrid hook." It is, of course, held that the trout cannot communicate their experiences to one another by any form of conversation (though leadership and imitative habit might have some effect), and it is also not suggested that a trout which had acquired an overpowering aversion to the angler's fly as a result of being hooked and breaking free, could transmit that aversion to its offspring by the mere fact of reproduction. Hence it is maintained that there is no such increasing "wariness" in English and Scotch trout. It is a curious thing that in discussing this matter the fundamental principle should have been overlooked by which Darwin and Wallace have long ago explained to the satisfaction of naturalists, the aversions and cautious proceedings of all kinds of animals, from the smallest insects up to birds, beasts, and fishes. The principle of natural selection and survival of the fittest accounts for the increased caution of trout in well-fished rivers in the simplest way. Assume (as is perfectly reasonable) that some trout are more shy than others "by nature," that is to say, are born so, that some are born with a slightly more rapid response to the sight of food than others-as one sees often enough with a lot of the young of any animal-then the increased shyness or pretended "intelligence" of the trout after many years' fishing follows as a necessity. The rash fish are caught and destroyed, the 
shy fish remain in the river, and-here is the important point, a well-ascertained fundamental law of hereditypropagate their like. They produce shy fish. Every year this selection goes on till you get a race of fish in the well-fished river which are so shy that they cease to rise at all! This unpleasant result is avoided by the proprietors of trout streams to a certain extent by introducing a race of trout which has not in consequence of over-fishing developed an innate shyness of character (such as the Loch Leven and some others) to mix and breed with the timid over-fished race.

It is in the same way that the human population of country villages, most sad to see, is every year rendered less intelligent than it was a hundred years ago. All the enterprising, intelligent young men and maidens are "fished" away, drawn by baits and hooks to the great towns; only the dull and relatively incapable are left in the village to marry and produce a new generation. The village population necessarily becomes made up of a dull stock-incapable, as appears from official reports, of being educated beyond a very low stage. In some districts 70 per cent. of the children are thus unintelligent, though not unhealthy or imbecile. It is possible that the want of home-training and example in very early childhood is to some extent a cause of the dullness of village children. And so it goes on, generation after generation, as facilities for leaving the village increase and inducements to stay or return decrease. The 30 per cent. of the new generation who have any "wits" leave the village, never to return. And no one re-stocks the village. That must be taken in hand soon. 


\section{$\mathrm{XX} I \mathrm{X}$}

\section{THE FEEBLE-MINDED}

A CONSIDERABLE proportion of the young which A are produced as a new generation of either plants or animals are not merely unlike their parents in some small particulars of colour, proportion, activity, and so on, but are, as compared with the normal or usual standard of the species, "defective"; that is to say, they are wanting in some organ or part, as though maimed, or by some cause restricted or reduced in regard to that part. This occurs in human beings, and in domesticated animals more obviously than in wild animals and plants, for two reasons: firstly, because in wild conditions the defective young die off very early in the struggle for existence and so escape human observation; whereas man protects his own "defective" young, and often, also, those of domesticated animals, so that they are allowed to "grow up" more or less; secondly, such defective structure appearing at birth, and therefore called "congenital," is carried on by heredity, more or less completely, should the defective animal or plant be allowed to breed. Such breeding of defective individuals is prevented in wild nature by their early destruction; their defects cause their early death by unfitting them for the competition and struggle which are in natural conditions rigidly severe. Only a few survive among the many thousands of each species born into 
conditions of limited food and space-conditions which are not sufficient to support more than a very small number so as to enable them to reach the adult or breeding stage of life. But man, on the contrary, protects his own young, and often those of his domesticated animals and plants, from this destructive competition, and thus allows those which are to a certain extent defective to breed.

The official returns of the Registrar-General record every year a proportion of deaths of infants which are entered as due to "congenital defects." These defects are of many and various kinds. A frequent "congenital defect" is one which does not necessarily cause death, namely, the imperfection of the wonderfully elaborate organ of sight, rendering it useless. Children often are born blind, and so are a certain proportion of each species of animal normally provided with eyes-dogs, horses, cattle, birds, fish. Even insects, lobsters, and crabs are in quite considerable and definite number born blind. The inborn or congenital defects of the eyes which result in blindness are of several kinds. The whole of the eyeball or eyestructure may be atrophied, that is to say, dwindled and incomplete, or one essential part only may be defective, and the rest quite well-formed; or, again, the nerves connecting the eye with the brain or the several parts of the brain concerned in the function of sight may, one or more of them, be defective. Wild animals born in this condition must perish, except when they happen to be born in caverns or in the deep sea. Then they are no worse off than animals with "good" eyes. But the animals with good eyes, or even with only somewhat defective eyes, will follow up the gleams of light which in moving about they have the fortune to encounter, and so will escape from the cavern or dark depths of the sea, leaving behind in the dark only those with defective eyes. These will 
breed together, and perpetuate their defective eyes in a more and more marked degree in successive generations. Always those which can see, or see only a little, will leave the dark place, and so at last there will be a race of animals established in such places with defective eyes (as in the ocean, at a depth of two thousand fathoms, and in the great caves of Europe, and notably in the Mammoth Cave of Kentucky, U.S.A.), and often the eyes will altogether disappear. This, however, is a digression.

The cause of congenital defect in eyes is not obvious. The failure of the germinal substance of the reproductive egg or particle detached from parents with sound eyes, to unfold itself - to develop-into a creature with sound eyes like those of its parents, is apparently due, in some instances, to one cause, and in other instances to other causes, of none of which can it be said that we have a satisfactory and comprehensive knowledge. The same want of full knowledge exists in regard to the causation of other congenital defects. These are as numerous and varied as the parts of the body which may be from birth onwards, in one instance or another, distorted, devoid of some essential inner structure, swollen to great size, or shrunken, or even absent altogether. Such defects are sometimes caused by mechanical pressure or nipping in early stages of growth before birth, but there are many which cannot be accounted for in that way. The wonder really is not that the inconceivably complex structure of higher animals should sometimes fail, in this or that part, to develop in due course from the simple-looking germ, destitute of visible structure, but that it should, on the contrary, so regularly and completely come off successfully in millions of instances every day. We can imagine or suggest disturbing agencies which may be the causes of failure, but it is very difficult to demonstrate with certainty the causes which have been at work in each and every case. I 8 
One result of failure of the germ to "grow up" into the perfect likeness of its parents is that it may "throw back," as the breeders say, and resemble in this or that quality a remote, even an extremely remote, ancestor. It is suggested by some inquirers that the congenital or inborn defect, frequent in human beings, which is called "feeble-mindedness" is a reversion or throw-back to the condition of the brain in the animal ancestors of man. That is possible, and, in view of some cases, seems probable. But it must be noted that we do not know what are the causes which favour throwing-back, or "atavism," as it is called, in regard to all sorts of structures, and that the mechanical conditions connected with the growth of the cavity of the skull in which the brain itself grows are so very elaborate that it is obvious that a very slight disturbance of one element or another might arrest or turn aside the growth of that vastly complex organ, which has become so much larger and more delicate in man than in the animals from which he has, at no remote period in the history of life on the earth, taken his origin.

Mankind have always within the period of written records (a mere trifle in the lapse of time since man became man) regarded mental defect and aberration as due to fantastic causes. To this day we use the word "lunatic" for one of the two typical forms of mental aberration: we imply that the moon is concerned in its production. The other form of brain-failure has appropriated the term "idiot," which, it is surprising to find, was less than two centuries ago applied in common speech to any person who was characterised by independence of judgment. The term "softy" is a common and really more suitable term for this class, whilst "cracked" is the word applied to a lunatic. The notion that mental aberration is due to "possession" by evil spirits, which can be expelled and the patient accordingly cured, was 
prevalent a century ago, and the belief is common at the present day (though quite erroneous) that people "go mad" in virtue of some immaterial and unaccountable influence, and may therefore "go sane" again. The lunacy laws and the laws relating to the care of the feeble-minded in this country are admitted to be tainted with ignorance and misconception, and both are in process of correction by the Government of the day.

The approved professional terms used in distinguishing the varieties of "the mind diseased" are not accepted with much favour by the public, and it is unnecessary to introduce them here. The important fact is that persons of diseased mind may be separated into two groups(a) the idiots or softies, and (b) the lunatics or cracked people. The idiotic group are those with a defective amount or quality of brain substance (whether the skull itself is small or abnormally distended by "water on the brain "), and are more or less incapable of being educated. They are often subject to epileptic fits, and are usually weakly in build, though they sometimes have great muscular strength. The "feeble-minded," of whom so much has lately been written, owing to the recent report of a Government Commission, belong to this group. They are distinguished from the more marked section of idiots in that they are not absolutely devoid of some intelligence, and are capable, under proper supervision, of some degree of self-control. Some of them even can take part in industrial operations, though they require constant direction when so employed, and are never, even in the least serious cases, susceptible of mental development beyond a strangrely and abruptly limited degree. Contrasted with the idiots are the lunatics; they often are gifted with the highest receptivity, and frequently are men or women of the highest education and intellect, normal in every feature of body and mind except that 
their mental machinery works in a defective, "mad" way as to one or more subjects-often only as to one subject or class of subjects. They exhibit in different individuals a vast variety of illusions and propensities which may be merely unreasonable or may be dangerous to themselves and to others.

It seems that the idiotic and feeble-minded are devoid of, or defective in, general mental receptivity, although in regard to a few things they may have retentive but unintelligent memory. Even the less afflicted among them are incapable of "thinking" at all, because their defective memory or receptivity gives them nothing to think about. On the other hand, the lunatic exhibits the ordinary receptivity of a healthy human being, but thinks wrongly or absurdly upon one or a few lines, though normally and soundly upon every other.

The State in civilised countries has long since made provision for the proper medical care and restraint of lunatics and of the extreme cases of the other class, the idiots. But by an oversight in this country, which the gravedigger in Hamlet would consider very natural, the less extreme cases of idiocy - the so-called feeble-minded -have been left without State guardianship. It is a fact that these cases occur both in the wealthiest and the poorest class of the community, though they are put away under medical care by well-to-do families, and are left by the very poor to wander about and get into terrible mischief. Hence there has grown up a belief that feebleminded offspring are more frequently produced by mentally sound parents who are very poor than by those who are rich or well-to-do, though there are not facts or figures which establish that conclusion. It has further been maintained that this supposed large proportional rate of production of feeble-minded among the poorest, ill-fed, ill-housed, and vicious dregs of the 
community is due to the action of defective nutrition, alcoholism, and lack of fresh air and healthy occupation upon the parents, and that a deterioration of the reproductive material, a twist, as it were, of the inner substance of the stock or breed in the direction of feeble-mindedness, has been thus established.

In reply to this somewhat hasty but at first sight plausible conclusion, we maintain ( 1 ) that the definite defect called feeble-mindedness is as common in wellnourished, well-to-do families as in the poorest; (2) that it is not proved that lack of food and good air can act upon the germs contained in a parental animal, so as to alter it in such a way that the brain of offspring begotten by that parent will not develop in normal structure and proportion; and, moreover, that "it has not been shown" (that is the important clause of the statement) that defective food and air can so alter the germs in a parent as to cause other deformation or structural defect in the young which grow from those germs. It is, on the other hand, true that such defect of food and air may cause the death of the parent, or may directly cause the death of the young, if the young are subjected to such defective conditions of life. It is necessary to point out, in reply to those who hold the starvation theory, of feeble-mindedness that it is capable of being handed on by hereditary transmission once it has appeared, and that in the most wretched groups of the population, both in cities and in country villages, the feeble-minded are not taken in charge by any authority, but leave their parents and shift for themselves, and, owing to their weakness, accompanied by unrestrained animal desires, they become, in an irregular way and at a very early age, themselves the parents of feeble-minded children. Thus feeble-mindedness is increased in the poorest class, but not in that of the rich. The facts ascertained are too horrible and painful for 
citation here. The recent Commission has made it clear that it is absolutely necessary for the State to interfere and prevent this terrible increase of helpless imbeciles.

There are eighty-four schools in London for the education of children who are not included under the extreme terms idiots or imbeciles, but are "feeble-minded and defective." They are attended by 6000 children, of whom about two-thirds learn some useful manual work, whilst the rest are hopeless, and require permanent custodial care-which at present is not to be had by those whose parents cannot pay for it-but will, there is every reason to hope, soon be provided for them by the State. In its absence they constitute a real and ghastly danger to the community, since some of them are certain to propagate their kind, and not only will thus add to the existing large body of imbeciles, but perpetuate the taint of feeblemindedness in the race.

It is an interesting question as to whether there is a definite gap-a difference of kind between these poor, defective children and the markedly stupid boys and girls of some village schools. I am inclined to believe that there is. The one group does not pass by a gradual series into the other. It has been stated that in some remote country districts of England only one-third of the school children can be taught more than the merest elements of writing, reading, and arithmetic; the majority are immovably dull, only the minority are as bright as ordinary London children. But even the dull village children get so far as to master the elements of learning, and probably their brains are not structurally defective, but only inactive for the time being. They may hereafter become village Hampdens. It certainly does seem to be the fact that the villages are continually deprived of the more intelligent members of their population by the attractions of the big towns, and that only the duller portion stay to breed in 
the village like the blind animals in a cave. But dullness is not identical with feeble-mindedness.

It is maintained that even in towns the multiplication of the hard-working, cautious, and capable section of the community is at a standstill. Its members seek comfort, intellectual exercise, and self-culture; they refuse to deprive themselves of these things, which cost money, and to spend that money on bringing up large families. On the other hand, the far more numerous "working-class" has no such ambition as a rule, and no anxiety as to what is to become of its offspring, however numerous. The more children the larger are the earnings of the family, and all in turn shift for themselves at an early age. The rates pay for such education as they require, and their parents have no desire to push them up the social ladder; but food, lodging, and clothes cost money. The workingman who desires to read, see things for himself, and be more than an animated $\operatorname{cog}$ on a wheel, cannot afford to have children and transmit to them that modicum of intelligence above the average which distinguishes him from his fellows, and demands for its cultivation the money with which he might keep a large family. Consequently the population is more and more largely replenished by the unenterprising poor and the unenterprising rich; the group which is enterprising and capable, and directs the work and thought of the civilised world, is, by the very qualities which make the increase of its strain desirable, debarred from contributing its fair proportion to the increase of the population. Is it possible for the community, by any system or by legislation, to overcome or evade this unfortunate tendency?

The neglect by both the local and central government to provide any supervision of feeble-minded children has had a special result of a strange and unhappy description. Let me hasten to say that now that we have secured by 
recent legislation the vitally important medical inspection of children in connection with Board schools, and the registration and official inspection of feeble-minded children which will surely be made compulsory before another year has passed, the danger of which I am about to speak will very shortly no longer exist. It is this. Feeble-minded children (whose condition falls short of that of actual idiocy) are almost impossible to manage as members of an ordinary family or household. Their condition is often not properly recognised; their parents or guardians find them to be obstinate, unteachable, and dirty. Often, when the family is poor, they are, under these circumstances, "boarded out" for a very small payment, or even taken charge of, out of charity. None of the persons concerned in these transactions know that they are dealing with a hopelessly unteachable child, born with this defective brain. They find scolding has no effect in guiding the child, mild chastisement fails, and the poor ignorant foster-parent (sometimes even the child's own mother) becomes exasperated and determined to subdue what seems to be mere obstinacy and indifference. The awful demon of cruelty is let loose. What seems at first a virtuous determination to control and regulate the child's behaviour for its own good leads to the infliction upon it of blows of savage violence, then to the less dangerous but revolting attempt to enforce obedience by the pain caused by a burn, and to starvation as a final instrument of discipline. A very large number of the cases of cruelty to children and adolescents which from time to time are brought into the law courts have their origin in the fact that the victim was "feeble-minded," and that the guardian found guilty of cruelty did not (any more than do the judge and jury) understand or, indeed, know anything at all about such a condition. Often the feeble-mindedness itself has been attributed to the cruel 
treatment of the child, whereas the latter really was set going by the former. To a large extent the community is to blame for allowing "feeble-minded " children to be boarded out except in proper medical institutions, guaranteed and inspected by State authority. It is the same story as that which was once common enough in regard to "lunatics," but has now been put an end to by the law. The boarding-out of children, whether healthy or weak-minded, should in all cases be illegal, except under proper official sanction and guarantee. It is not only for the sake of the children that this provision is necessary. It is certain that foolish people have been led, in the absence of all restraint and interference by public authority, to undertake without evil intention the care of discarded children, and have been led on by the hopeless dullness and obstinacy of a child with defective brain into cruel treatment of it; and when in some cases the child has died as the natural consequence of its congenital feebleness, the miserable guardians have been found guilty of causing its death. Though little excuse can be made for such miscreants, it is greatly to be desired that the law should step in at an earlier period, and both ensure proper care for the feeble-minded child and remove from unqualified guardians the chance of developing from a state of mere ignorance into one of criminal responsibility.

The Government Commission on the Treatment of the Feeble-Minded, which has recently reported, has adopted the view which I have explained in this article as to the origin of feeble-mindedness. A large amount of evidence was taken by the Commission from medical experts and others. A certain number of the witnesses maintained the opinion that feeble-mindedness arises from the action of deficiency of food, of overcrowding, and possibly of drunkenness upon individuals of healthy strain, whose offspring, as a consequence, exhibit feeble-mindedness. 
Some naturalists, who have committed themselves to a pious belief in what is vaguely called "the transmission of acquired characters," think themselves called upon to support this opinion, in consequence of a notion that their belief would be rendered more reasonable than it is at present were such an origin of feeble-mindedness demonstrated. Apart from the fact that it is not demonstrated, it is difficult to see how, supposing it were, such a causation could be considered as a transmission of an acquired character. The ill-fed, drunken parent of a feeble-minded child (when discovered and examined) is not found to have "acquired" a condition of the brain agreeing with that of his or her feeble-minded offspring, though sometimes such parent is found to have been himself or herself born with a defective brain. No theory of organic memory, of engrams, inscripts, or transfer of molecular vibrations can enable us to present a plausible mechanical scheme of the way in which the acquired general condition (restricting ourselves to what is new and acquired) of an ill-fed parent can be definitely and specifically re-embodied in his or her offspring, as the peculiar structural condition of brain which is called "feeble-mindedness." It has not been shown, so far as I am aware, that privation in regard to the food of a parental organism gives rise to new congenital qualities in the reproductive germs which that organism throws off. 


\section{$\mathrm{XXX}$}

\section{DEATH-RATES}

THE chief index or measure of the health of any locality is what is called "the death-rate" of that locality. Although there are several other important evidences as to the healthiness or unhealthiness of any given area, the "death-rate" is the chief and most obvious indication of the advantageous or disadvantageous action of the conditions of any given city or other chosen area upon human life. Its records are more easily kept with an approach to accuracy than are records of cases of sickness not terminating in death. The cause of death has to be certified in civilised communities by a medical man; the total number of deaths in a year is given by the number of burial certificates. The death-rate is stated at so many per thousand of the population per annum. Thus, in a city of 5 million inhabitants, - that is to say, 5 thousand thousands-a record of eighty thousand deaths in the year gives 16 deaths for every thousand persons living. That is called "an annual death-rate of 16." The record for any single month may be stated (as it is stated at intervals in the newspapers) "as at the rate of so many in the thousand per annum," by multiplying the actual monthly number per thousand by $\mathbf{I} 2$. Thus, in the case of the city just cited, if the death-rate were the same in every month of the year-namely, 
16-it would mean that 6500 persons died regularly every month. But we should probably find that in some month or other as few as 54I7 persons died. That would be reported "as at the rate of" 13 per thousand per annum ; since, if every month gave only 54I7 deaths, we should get 65,000 deaths a year, which works out at 13 in the thousand in a population of 5 millions. In other months it might run as high as 19 or 20 (representing over 8000 deaths a month), although, taking all the months together, the deaths are at the rate of 16 in the thousand for the year.

The bald statement of the death-rate, of course, admits of much analysis where proper records are kept. Thus the death-rate from different diseases and groups of diseases can be stated, and the death-rate in each group at different ages and for the two sexes can be given where proper records are kept. In this country the records of population in various areas and for the whole country, and of the deaths from various causes, and at different ages, are collected and tabulated by the Registrar-General and his officials. The annual reports issued by him show what an amazing progress has been made in increasing the security of life in our great cities within the last fifty years. Thus, in London, the death-rate was, fifty years ago, 24 in the thousand. In 1906 it was only $15^{\circ} 1$ in the thousand-it has gradually fallen, year by year, so that now it is less than two-thirds of what it was half a century ago. In Manchester and Liverpool it was about 26 twenty years ago, and has fallen to 19 in Manchester and to a little over 20 in Liverpool. In the same period the improvement has been (omitting fractions) from 19 to I4 in Bristol; from 20 to 16 in Birmingham; from 20 to 14 in Leicester. This great diminution in the death-rate has been coincident with the expenditure of public funds on the improvement of the water supply and the sewage 
arrangements of those cities, as well as with the enforcement of regulations to prevent overcrowding, and with the demolition of the most insanitary houses. Rules as to the removal of filth from the neighbourhood of dwellinghouses have been obeyed, and sick persons suffering from infectious diseases have been removed from dwellinghouses and conveyed to special hospitals. There is no doubt that the diminished death-rate is due to the action thus taken, and more will be done in the future to the same end. The proper provision of pure milk (at a reasonable price) for the food of the youngest children, of regular meals for older children, and the protection of adults from the too frequent inducement to indulge in the use of distilled spirits, will be taken in hand by the municipalities, and lead to a further diminution in the death-rate.

We may, indeed, soon have to ask whether, in a population which has become so much less subject to diminution by death than was formerly the case, there is not too great an increase by birth-too great, that is to say, for the existing means of employment and foodproduction. A most serious, indeed, an alarming fact, has recently come to light in the study of this question, namely, that the increase of the population is due (as pointed out on p. 279) to the proportionately larger number of births amongst the poorer, and even destitute, sections of the community who have not the means of training and rearing their children satisfactorily, and are themselves likely to transmit incapacity of one kind and another to their offspring; whilst those who have valuable hereditary qualities and are prosperous have-it is clearly established-relatively few children-and, in fact, do not increase the population. Whether this condition of things constitutes a real danger, how it will ultimately work out if left alone, and how the difficulty is to be met, are 
problems for statesmen which cannot be solved off-hand, but require knowledge not only of the crude facts of statistics, but also of the causes at work. Scientific knowledge - that is to say, thorough and unassailable knowledge- of the laws of heredity, of psychology, and of the natural history of human populations, are among the essential qualifications for those who have to face and deal with this difficult matter. And who is there who has this knowledge or is even trying to obtain it? Not the State in this country or its officials : for in every department of government (however capable some of the subordinates may be) there is a determined opposition to and fear of Science on the part of the political and highly paid chiefs-the jealous fear due to complete and deadly ignorance. 


\section{XXXI}

\section{GOSSAMER}

G INE as gossamer! Town-bred folks never see it, and do not believe in its existence; they think it is a poetical figment, like "honey-dew." That, too, is nevertheless a real thing-a honey-like juice poured out by the little plant-lice or aphides. Gossamer is a very real and a most beautiful thing. You may see it on the hill-sides in fine October weather, when the sun is bright but low enough to illuminate the delicate threads and reveal the "veil of silk and silver thin" spread over Nature's loveliness. The innumerable threads glisten, and are so fine that they shine with iridescent colours, as do the equally delicate soap-bubbles fabricated by men and boys, and from the same cause. When the eye gets accustomed to them and traces themrippling and glimmering over acres and acres of grassland-one feels disconcerted, almost awestruck, by the revelation of this vast network of threads. Sometimes the gentle currents of air break them loose from the herbage, and they float at a higher level and envelop the puzzled intruder in an almost invisible entanglement of fairy lines. Sometimes they become felted together in flakes and float or rest as incredibly delicate tissue, woven by unseen mysterious agency.

When the slopes of the new golf course at Wimbledon 


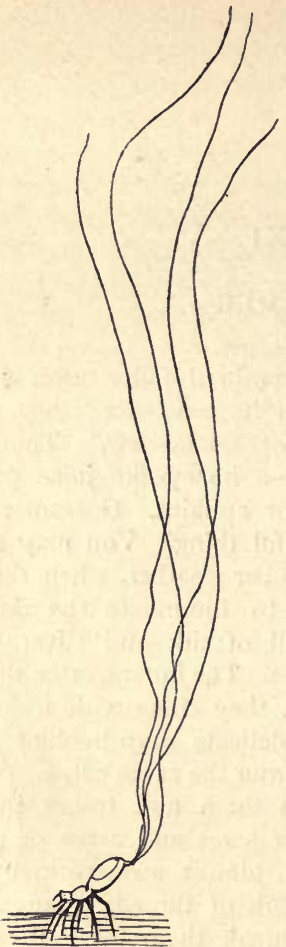

FIG. 47.-A young spider (four times the natural length) raising its body upwards, whilst the four silk threads (gossamer) spun by it float in the air, and so draw out further liquid silk from the spider. They increase in length to three or four yards, when they float upwards, carrying the spider with them. (After McCook.) were covered last autumn with gossamer, my friends were asking what was its origin, some boldly asserting that it was impossible that such a vast acreage of threads could be produced, as others maintained, by tiny unseen spiders! Yet that is the true history of gossamer. Hundreds of thousands of minute spiders, young, and of a small kind, are present in grass fields in autumn, and throw out these marvellously fine threads from their little bodies (Fig. 47). Those who at first sight doubt this origin of gossamer are only in accordance with their forefathers. The French peasants call it fil de la Vierge; old English writers held it to be "dew evaporated." A great discoverer and leader of science in his time, Robert Hook, who was elected with Nehe- 
miah Grew as secretary of the Royal Society in 1677 , and published a wonderful illustrated book called Micrographia (see p. 173), wrote of gossamer. He was so far from recognising its true nature that he says: "It is not unlikely that those great white clouds which appear all the summer time may be of the same substance." Yet it is now a simple and certain fact of observation that the countless threads in question are the work of minute spiders!

The pretty name "gossamer" has puzzled the etymologists and led to some far-fetched suggestions. That favoured by the authority of the great Oxford dictionary of the English language is that it is a corruption of "Go-summer," because gossamer appears in autumn and is associated with St. Martin's summer. This is like saying that the word "cray-fish" refers to fish that live in a "cray" or brook, instead of deriving it from the French word ecrevisse. The Germans call gossamer Sommerweben. But the Latin word for cotton is gossypium; and there is an Italian word, gossampino, which occurs in an English form, gossampine, in the sixteenth century, and means a kind of silk or cotton obtained from the fluffy hairs of a plant called bombax. We also find "gossamer" spelt "gossamire" in English of that date; and it seems to me most likely that an Italian word gossamira, signifying "fairy-cotton" or "magic goosedown," is the origin of our word.

There are 500 different kinds of spider carefully described as occurring in the British Islands, and about 2000 others from remoter regions. Precisely which of them forms the "gossamer" of our meadows it is difficult to say, as all have the habit of secreting a viscid fluid from one or two pairs of projecting spinning knobs or stalks, which are seen at the hinder end of the body (Figs. 48, 49, and 50). The viscid fluid is poured out by a great number 
of minute tubes, and hardens at once into a thread, which

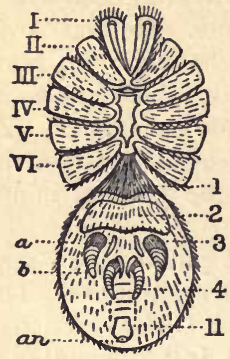

Frg. 48.-View of the lower surface of the head and body of a large Burmese spider, known as Liphistius, to show the spinnerets ( 3 and 4$)$, which are really reduced or rudimentary legs, and are in this spider retained in their original position, instead of being pushed down to the end of the body, as they are in all other spiders (see Fig. 49, spn). I. to VI., the basal joints of the legs and palps of the head-region; I, the first abdominal segment ; 2 , the second ; 3 and 4 , the legs of the third and fourth abdominal segments, which are the spinnerets; II, the eleventh abdominal segment-in front of it rudiments of the segments 5 to Io are seen ; $a n$, anus ; $a, b$, inner and outer lobes of the first pair of spinnerets. is wonderfully fine, yet strong. Different kinds of spiders make use of these threads for different purposes, hence their name "spinners." Some make burrows in the ground and line them with a felt of these threads, others enclose their eggs in a case formed by winding them round the eggs, others form "snares" of the most marvellous mechanical ingenuity with them, by which insects are entangled and are then paralysed by the poisonous stab of the spider's claws, and have their juices sucked out of them at the spider's leisure. The snares of spiders are in some species merely irregular webs fastened and suspended by threads, in other cases they are gracefully-modelled funnels or cups, whilst a third kind, the disc-like webs made up of radiating and circularly-disposed threads fixed in a geometrical pattern, excel-in the mechanical precision of their workmanship and the masterly treatment of engineering difficulties - the constructions of any other kind of animal. It is amongst this kind of spiders that the formation by the spinning knobs of threads or lines and their use in various ways is most 
general and frequent. The smaller spiders expel the viscid thread, drawing it out from their bodies by their own movement away from the object to which it at first adhered. When it breaks loose from that support it is carried upwards by air-currents and drawn out from the spinner's body to many yards' length (Fig. 47). It then becomes a "flying-line," and the spider may sail away on it or run up it and disappear. The celebrated story of the Indian juggler's performance - traditional and even solemnly attested by witnesses, but failing to pass the test of photography-must have been suggested by this common, yet wonderful, proceeding of small spiders. The juggler, standing in an open place, surrounded by a ring of spectators, uncoils a rope, 50 feet long, from his waist, and holding one end, throws the other up into the air. The rope,

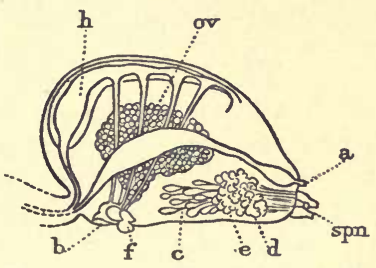

FIG. 49.-Section through the body of a spider to show the spinning organs. $h$, heart connected by four big veins with $b$, the lung-bosks or air-gills ; $f$, genital lid; $o v$, ovary; $a$, the anus; $s p n$, the three pairs of spinnerets or spinning warts; $c, e$, and $d$, the three kinds of glands producing liquid silk, viz., cylindrical, tree-form, and pyriform. These are one thousand in number in the common garden spider, and each has its separate spout or spigot standing up on one of the spinnerets (see next figure).

without any support, remains stretched and upright. A small boy now enters the ring and climbs up the rope, draws it up after him, and disappears with it in the upper air! That is an illusion, but it is precisely what thousands of small spiders are continually doing. A big spiderthe well-grown female of the common garden spider, for instance, cannot do this-her thread is not strong enough, and her weight is too great. But the male of the same 
species, who is much smaller, fortunately for him, can safely run on a hanging line-and thus can rapidly escape from the side of his mistress, who, after receiving his caresses, has an unpleasant habit of seizing, killing, and

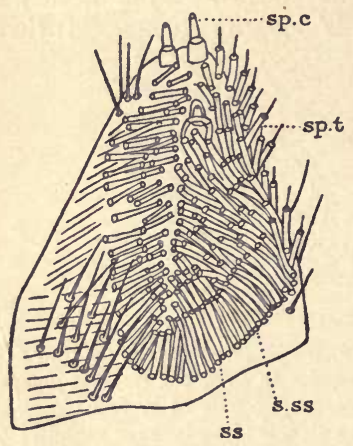

Fig. 50.-One of the two middle spinnerets of the common garden spider (Epeira diadema), to show the three kinds of spouts or spigots (one thousand in all) corresponding to the three kinds of silk-glands. Each kind of "spigot" pours out a different kind and size of thread. $s p . c$, one of the big spigots of the cylindrical glands; sp.t, middlesized spigots belonging to the treeform glands; ss and s.ss, the smallsized spigots of the very numerous pyriform glands. sucking the blood of the adventurous male, should he linger longer in her company, and fail in the agility and rapidity of his exit.

The threads of the garden spider (the Porte-croix of the French, white-cross spider, Epeira diadema, Fig. 51) are fixed by astronomers in their telescopes for the purpose of giving fine lines in the field of view, by which the relative positions of stars may be accurately measured. For a century astronomers desired to make use of such lines of the greatest possible fineness, and procured at first silver wire drawn out to the extreme limit of tenuity attainable with that metal. They also tried hairs ( $\frac{1}{600}$ th of an inch thick) and threads of a silk-worm's cocoon, which are split into two component threads each only $\frac{1}{2000}$ th of an inch thick. But in 1820 an English instrument maker named Troughton introduced the spider's line. This can be readily obtained three or four times smaller in breadth than the silk-worm's thread, and has also advantages in its 
strength and freedom from twist. In order to obtain the thread, the spider is carefully fixed on a miniature "rack," and the thread, which at the moment of issue from the body is a viscid liquid, is made to adhere to a winder, by turning which the desired length of firm but elastic thread can be procured. It has been proposed to use spiders' silk in manufactures as a substitute for silk-worms' silk, and pioneers have woven gloves, stockings, and other articles from it. It appears that there are species of spider in other parts of the world whose thread is coarser and more suitable for this purpose than that of any of our British spiders. But it is estimated that the expense in feeding the spiders-which require insect food-would make the thread obtained from them far too costly to compete with silkworm silk.

A number of different kinds of the lower animals besides spiders have the power of producing threads. The caterpillars of some moths are especially noted for this, since their thread is familiar

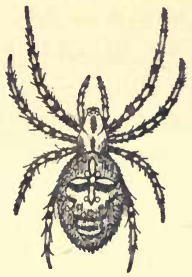

FIG. 51. - The common garden spider, more correctly called the whitecross spider (Epeira diadema): a female drawn a little (one-fifth) larger than life.

to us all as "silk." It is secreted as a viscid fluid by a pair of tubes opening at the mouth, and hardens on escape. Even some marine creatures-the musselsproduce threads, in this case from a gland or sac in the muscular foot, by means of which they fix themselves to rocks. A very big mussel-the Pinna-called Capo lungo by the Mediterranean fishermen and Capy longy at Plymouth, where they are also found, produces a sufficient quantity of fine horny threads to be used in weaving, and gloves have been made at Genoa from the shell-fish silk. 
The threads produced by the hardening of the tenacious fluid exuded by these various animals were probably simply protective in origin. The curious caterpillar-like creature Peripatus spits out a viscid fluid when it is disturbed, which hardens into threads, and hopelessly entangles any small enemy.which may venture to attack it. Threads of a poisonous nature are thrown out by jelly-fishes, polyps, and sea anemones, and serve them both as defence and as means of paralysing and capturing prey. A later stage in the use of such threads is their "felting" to form a case or tube (as in the sea anemone called Cerianthus), and so their application has gradually developed to the formation of egg-cases, snares, and the wonderful web of the geometric spider, and the countless "flying-lines" of smaller spiders, which make up the mysterious thing we call "gossamer."

As to the limits of the tenuity of the threads of gossamer there are no direct observations. Probably they

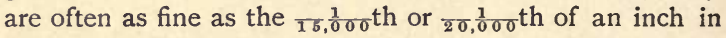
diameter. The condensation of a very minute quantity of moisture on gossamer threads and spiders' webs no doubt helps to make them more readily visible to us in October weather than they are in full summer, when such moisture would not condense except in early morning or at sunset. It seems strange that man should have been unable to produce a thread so fine as that of the spider, but this reproach has now been removed. Spun glass is easily obtained $\frac{1}{1000}$ th of a inch in diameter; but Mr. C. V. Boys, F.R.S., has, by fusing quartz (rock-crystal) by the oxy-hydrogen flame, and drawing it out by means of a small arrow (a straw), discharged from a bow-the near end of the arrow being adherent to a fused droplet of quartz which is held fast - produced threads of great strength and of extraordinary tenuity. The fineness can be regulated by the rapidity with which the drawing is 
effected. The threads are prepared (for use in suspending swinging bars in delicate measurements of force) of a thickness of $\frac{1}{10,000}$ th of an inch. Some have been made so fine as to be not only invisible to the naked eye, but to be only vaguely indicated by the highest powers of the microscope. They are estimated to be only one-millionth of an inch in diameter. It is difficult to form any mental picture or conception of these finest quartz threads spun by Mr. Boys. But the following fact helps us to realise how delicate they are. A grain of sand just visible to the eye - that is to say, $\frac{1}{100}$ th of an inch long, the same in breadth, and the same in height-would make twenty miles of such thread. 


\section{XXXII}

\section{THE JUMPING BEAN}

NE way of thinking of the six hundred thousand kinds or species of insects-those tiny, ubiquitous fellow-creatures of ours which inhabit nearly every corner and cranny of the earth's surface-is to associate them with the plants upon which, either for food or protection, the greater number of them are dependent. This makes them appear less overwhelming in their astonishing and, at first sight, meaningless variety, than when one calls them to mind pinned out in long lines in innumerable drawers and cases, or assorted, like with like, in the wonderfully accurate and interminable pictures of them produced by those patient benefactors of mankind the systematic entomologists. Every plant of any size has a number of insects associated with it, living more or less completely on its substance, or making its home in some part of the plant. Some trees are known to have more than a hundred and fifty kinds or species of insects thus dependent on them, those which are vegetarian serving in their turn as food to a variety of carnivorous insects.

The ways in which insects are associated with plants may be briefly stated. It must be remembered that often, though not always, one particular species of plant, and that only, is capable of serving the needs of a given 
species of insect. Thus, the leaves of a given plant are the necessary food of the grubs of one or more insects which bite their food; its internal juices serve others which suck; its roots others; its nectar in the flower others, which in return serve the plant by carrying away its pollen and fertilising the other plants of the same species which they visit. Protection is sought and obtained from the same plant by insects which burrow in its leaves, or roll them up, or cut them into slices and carry them away, or hide in its bark, or in the flowers, or in other parts-or burrow for food and shelter into its wood. Others lay their eggs in the soft buds, producing or not producing according to their kind distorted growths, known as "galls" (one plant is known to have as many as thirty species of gall-flies which make use of it). Other insects lay their eggs in the flower-buds and immature fruits, or place them on the plant so that the young grubs, when hatched, can at once eat into those soft parts. Others bore into the wood or into hard or fleshy fruits expressly to lay their eggs, or into the ripe seeds. Certain ants live in chambers specially provided by the woody parts of the plant for them, and benefit both themselves and the plant by devouring other insects which seek the plant in order to devour it. In a museum of natural history there should be exhibited at least one plant with specimens and enlarged models of all the insects which depend upon it for food, protection, or nursery, and with accompanying illustrations of the way in which those purposes are served.

A curious product of the relationship of an insect and a plant is the so-called "jumping bean," which is brought to this country from Mexico, and may be purchased in some of the London shops which deal in "miscellaneous" articles. They have been known for some years, but are becoming now a regular article of commerce. As one buys 
them (Fig. 52) they are segments of a globular fruit which has divided into three, comparable to the familiar segments of an orange, but less numerous. They are about one-third of an inch long, light, quite dry, and apparently hollow, without any visible opening. Two sides of the little capsule are flat, and the third side is bulged and
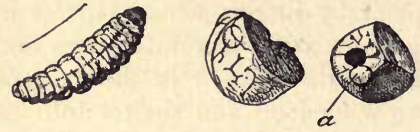

FIG. 52.-On the right two jumping beans; on the left the caterpillar removed from a jumping bean. The figures are a little larger than life-size, as is shown by the line drawn near the caterpillar giving its actual length. The shape of the "beans," as segments of a tripartite sphere, is seen. One shows a round hole, with a lid-like piece marked $a$, removed from the hole. This hole did not exist when the bean first came into my possession in November 1908. At that time the caterpillar within was active, and the bean or fruit-segment often jumped. In April the caterpillar cut this round hole from within, leaving the circular lid in place, and became a chrysalis. The lid was pushed out, as shown in the drawing, by the moth when it escaped from the chrysalis in July. (Drawn from nature for this work.) rounded, so that the capsule easily rocks when resting on that side. When these dry fruits or segments of a fruit are brought into a warm room or placed near a fire so as to make them as warm as the hand, they commence to rock and move with curious little jerks. They jump as much as one-eighth of an inch from the ground, and advance as much as a quarter of an inch at a time, though by rolling they may progress a good deal more. They will often move seven or eight times in the same direction so as to make a progress of a couple of inches on a flat surface. and $I$ have found that if a cool surface or protection from warmth is within reach they will in the course of time arrive at that cool area and come to rest. When the plate on which they are placed becomes cool or the temperature of the room falls to what we should call "chilly," they 
cease to move, but can be roused again by renewed warmth.

How and why do these "beans," or, rather, fruit-segments (for they are not beans), move in this determined purposeful manner? The whole proceeding has a mysterious and uncanny aspect. They have no legs, no spring; they are simple little smooth capsules, and yet they jump and seemingly "walk" about. The explanation is that there is a grub inside each so-called " bean." Cut one of the beans or capsules open, and you find that it is a very thin-walled and hollow case, but coiled on itself in the cavity you open, and about half filling it, is a yellowish white grub (Figs. 52 and 53). It is not a "maggot," but a "caterpillar," that is to say, it is not legless, but has eight pairs of legs-namely, three pairs of short walking legs in front, four pairs of sucker-like legs, and a hinder pair of larger size called "claspers." It has a hard brown plate on its head, and possesses hard jaws. It refuses to leave the opened capsule, and crawls back again if forcibly removed, and in the course of a few hours spins a silken cover to replace the piece of "shell" you have cut away. Mr. Rollo has lately succeeded in getting the caterpillar to patch up its injured residence with a thin piece of glass, such as is used by microscopists, which he-put in place of a side of the capsule removed by a knife. $\mathrm{He}$ was thus able subsequently to watch through the glass the movements of the little creature when it causes the mended capsule or "bean" to jump. It rears itself from the lower surface of the capsule, and gives a series of sharp blows to the roof, projecting its body with each blow, and thus overbalances the capsule, or, if the flat side is lying downwards, jerks it along much as one may sit with one's feet on the rail of a chair and cause it to jerk along the floor by the swinging movements of the body. The caterpillar does not 
die at once when removed from the capsule; it has been kept alive in a glass tube for a month.

So far so good. The next questions are: What Mexican plant is it that forms the capsule or tripartite fruit in which the caterpillar is found? How did the

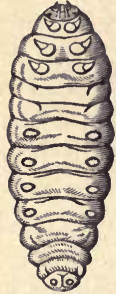

FIG. 53.-The caterpillar of the moth, Carpocapsa saltitans, removed from the jumping bean : magnified three diameters. Observe the jaws (with which the circular plate is cut in the bean before the grub becomes a chrysalis), eyes, three pairs of pointed legs, four sucker legs placed in the middle region, and followed by three segments without legs, and a terminal segment with a pair of suckers. (Drawn from nature for this work.) caterpillar get there? What kind of an insect does it turn into, and when? I will answer the last question first. The caterpillar turns into a chrysalis in the early part of the year, having first cut a perfectly circular ring in the shell of the capsule. The circular plate thus within the ring is not disturbed, and cannot be observed without very close inspection. The making of this perfectly circular cut without removing the piece marked out must be effected by a rotation of the caterpillar's head and jaws as a centre-bit-an astonishing performance. But when the moth emerges from the chrysalis, a gentle push is enough to cause the little circular plate to fall out, and the moth creeps through the hole to the outer world. The moth, which comes out of the chrysalis-coat, is a very pretty little creature (see Fig. 54), measuring two-thirds of an inch across the opened wings, which are marked with dark and reddish-brown-coloured bands. It is a close ally of the British codling moth, the caterpillar of which eats its way into the core of apples, and is familiar to all growers and eaters of that fruit. The codling moth and the Mexican "jumper" belong to a group of 
small moths called Tortricine, and they are named respectively Carpocapsa saltitans (the one whose grub or caterpillar inhabits the "jumping bean") and Carpocapsa pomonana, the codling moth. There are other British species of Carpocapsa, the grubs of which eat into the acorn, the walnut, the chestnut, and the beechnut-a distinct kind or species for each. None of these grubs cause the nuts they attack to "jump."

The "jumping bean" of Mexico is a segment of the triply divided fruit of a large spurge, which is called Sebastiana palmeri. The spurges are known in England as little green-leaved annuals, with yellow-green flowers and a milky juice. Botanists call them the Euphorbiacee, and in that "natural order" are included the boxwood tree and some tropical trees of great value and importance. None other than the Brazilian indiarubber tree, Hevea, of which we hear so much nowadays, its rubber to the value of $£ \mathrm{I} 4,000,000$ being exported every year from Brazil, is one

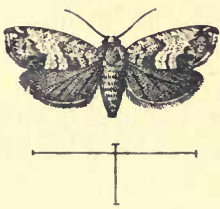

FIG. 54.-The moth, Carpocapsa saltitans, which escapes from the jumping bean or segment of the fruit of the Mexican spurge, Sebastiana palmeri, in which its caterpillar and chrysalis have passed their lives. The crossed lines indicate the natural size of the moth. (Drawn from nature for this work.) of them. So also is the Chinese candle-tree, which furnishes a tallow-like fat, made into candles in China. Others are the croton oil and the castor oil shrubs, natives of India, and the manihot or tapioca plant. The fruits of Sebastiana (the jumping bean) are very much like those of the croton; and as there are crotons (though not the one of the purgative oil) in abundance in Mexico, it has taken some time to make sure that the "jumping bean" is not the fruit of a croton, but that of the allied plant Sebastiana. It appears that there is no 
commercial value for this plant, and that those capsules which happen to contain a grub and move are collected from the ground by the native Mexican boys and sold as curiosities.

The moth (Carpocapsa saltitans) lays its eggs on the Sebastian shrub, and the young grub, on hatching, eats its way into the young fruit when the latter is still quite soft and the seed unformed, and so leaves no hole to mark its entrance. As the fruit swells the grub eats out the seed and surrounding pulp of the segment of the fruit into which it entered early in life. By the time the fruits are dry and fall to the ground the caterpillar is fully grown. Of course, it is only a very few of the capsules which are thus invaded by a grub.

The question very naturally arises, "Why should the caterpillar put itself to the great muscular effort of making the little capsule in which it is contained jump and move over the ground?" It seems probable that these movements are made in order to bring the capsule from an exposed position when it falls on to the ground - where it might be crushed or eaten by some animalinto a position of shelter, either into a hole, or under some stone or fallen wood. The warmth of the sun in an exposed position excites the caterpillar to activity, which ceases when it has reached the shade offered by some protecting cranny. In the same way I have applied artificial heat and, alternatively, shelter from heat, so as to cause the movements or the resting of the jumping bean in a London sitting-room.

These things and others of absorbing interest may be seen in the truly wonderful museum of Kew Gardens, where perhaps the visitor will be disposed to spend more time in cold weather than in the summer. The park at Kew Gardens, with its splendid forest and lakes, and its Italian tower, is one of the beautiful things of England, 
and it has a special quality even in this season of mist and veiled sunshine. I found there reeently, under the trees, as I did fifty years ago, a rare and strangelooking fungus, the Phallus impudicus of botanists,--a furtive denizen of the glades which in late spring are purple with wild hyacinths. The same spot in June presents within a few minutes' journey from the smoke and smell and noise of Piccadilly a perfect sample of what is, perhaps, the most beautiful sight in Nature-bright sunlight breaking through the young green leaves of a forest on to green herbage. And close by are the azaleas! 


\section{III}

\section{PROTECTIVE COLOURING IN ANIMALS}

E VERY one is familiar with some of the instances in which the natural colour of an animal helps to hide it from view. Green caterpillars, for instance, are less visible when among the green leaves which they eat than they would be were they brown, blue, red, yellow, or black. The little green tree-frog is difficult to see when he is clinging to a leaf, because his colour is the same as that of the leaf. Sandy-brown-coloured animals, birds, reptiles, and beasts of prey, are found on the sands of the desert; white birds, foxes, hares, and bears on the Arctic snow. The similarity of the colouring of these animals to that of the ground on which they live results in their escaping the observation of man's eye, and we are entitled to believe that they escape for the same reason the observation of other animals. They are thus in many cases protected from the attacks of enemies searching for them as prey, or in other cases they may themselves be enabled the more easily in consequence of their concealing colour to creep upon other animals and seize them as food. Some of the simpler cases of this resemblance between an animal and its surroundings are easy to observe, and the value of the resemblance as protection, or as a means of secret attack, is plain enough. 
But there are far more numerous cases in which the significance of colour as concealment, is not so immediately obvious. There are the curious stick insects, with long bodies and delicate long legs, sometimes with budlike knobs on the body which look like bits of the branches of trees, not merely on account of their colour, but on account of their shape. Shape or modelling has a great deal to do with the effective concealment of an animal. Then, too, there is the curious fact that some insects (and also some birds) when at rest on the stems of trees, are practically invisible, but if they spread their wings are conspicuous. The beech-leaf butterfly of Assam and Africa is of a purple colour, marked with a great orangecoloured bar on each fore-wing when the wings are open, and it is obvious enough. But when the wings are closed and the insect is at rest, the undersides only are seen, and are coloured so as to represent the veining and fungus marks of a dry brown leaf, so that not even a human observer, let alone a bird or a lizard, can distinguish at two-feet distance the butterfly from dried leaves placed near it.

A well-known little moth, with pale green mottled wings, is the only case in which I have myself watched the protection afforded by colour at work. It was on a summer's evening, when I saw this little moth zigzagging up and down with the most extraordinarily irregular flight, and a bird pursuing it. Twice the bird swooped and just missed his prey owing to a sudden turn and drop on the part of the moth. And then to my great delight the moth flopped against the stem of a tree on which was growing a greenish-grey lichen. The bird swooped again close to the tree, but failed to see the insect, and quitted the chase. It took me an appreciable time to detect the little moth resting against the lichen, and closely matching it in colour. There are endless examples known of such 
"protective resemblances," some of them (such as that of the buff-tip moth, which, with its wings closed, looks like a broken birch twig) being most unexpected and fascinating. In the forests of Madagascar, the whitish-grey tree lichens are imitated by thread-like growths on beetles, tree-bugs, locusts, and even lizards, with a wonderful concealing effect, and some other flat membrane-like insects are so much like the greenish and yellowish bark of trees, that we actually lost a specimen for some time in the case labelled "Mimicry," in which a series of these things was arranged by me for the edification of visitors to the Natural History Museum. It was found, after a day or two, to have been present all the time with other specimens on a piece of bark, from which it was indistinguishable.

Some eight years ago a distinguished American painter, Mr. Abbott Thayer, was able to add very importantly to our knowledge of the ways in which colour serves to conceal animals when in their natural surroundings. Mr. Thayer was able to do this owing to the fact that he was a devoted student of woodland life. This, however, alone was not enough. Mr. Thayer had the special ability to deal with this subject which comes from the trained eye of an artist. He had, above all, the knowledge of "tone values" and of the illusive and delusive effects of false shading and of colour-spots and bars, and of complementary colours and "irradiation"-which only a painter who deals every day in the most practical way with these matters can attain to. Mr. Thayer showed eight years ago-and demonstrated conclusively by means of models, one of which he presented to the Natural History Museum at my request-that in very many cases it is of no use for an animal to be of the same colour as its surroundings, since if the animal (a bird, or a quadruped, or a fish) is of plump and rounded shape and is 
observed under the open canopy of heaven, a deep shadow will exist on its lower surface and make it as obvious as a shaded charcoal drawing on a piece of light-brown paper. But if the back of the animal is of a dark tint and its belly white or whitish, then the effect of light and shade is (Mr. Thayer showed) completely counteracted and the animal becomes totally invisible in its natural surroundings.

Mr. Thayer's model demonstrating this consists of two life-size wooden models of ducks seated on a stick-one to the left, the other to the right. The stick, with the two models on it, is fixed horizontally in a box, which is open above (that is, has no lid) and is also open in front. The box is, in fact, a little stage, lit from above by the light of the sky, and its three remaining sides are suffciently high to form a complete background to the model ducks, whose perch runs across the "scene" at some 7 in. or $8 \mathrm{in.}$ from the floor of the box. The box itself is lined with a pale purplish-brown flannel, and each bird is tightly covered with the same material. When so prepared the box is placed on a table under a skylight (where it is to stay), the table being high enough to bring the ducks just below the line of sight. Of course, deep shadows are formed by the top-light on the under side of the beak, head, and body of the models, and in spite of their colour being itself identical with that of the walls of the box, they are as obvious as it is possible for anything to be. Now Mr. Thayer takes his paints and very carefully darkens the back of one of the ducks and whitens its belly and the under side of its head and beak. The light and dark regions merge into one another along the side of the bird by skilful gradation. When this shading and whitening is finished (and, of course, the perfection of the result depends on the continuance of the right amount of sunlight, which is not a thing one can always ensure 
in a London museum) the duck-model so treated is absolutely invisible at a distance of $10 \mathrm{ft}$. or $15 \mathrm{ft}$. and even when one is nearer escapes notice-looking like a haze or vague shadow of a bird even to an observer who knows nevertheless that it is there and is really as solid and large as the untreated model by its side. If now some one stretches out his hand so as to cut off the toplight falling on the painted model, it immediately becomes as solid to the eye as the untreated one, and when the hand is withdrawn it melts away again like Banquo's ghost. The models made by Mr. Thayer were, so long as I was director, exhibited in the small room between the fish gallery and the central hall of the Natural History Museum, and, if they have not yet been removed, are well worth a visit.

Mr. Thayer's models work perfectly, and astonish every one who sees them. The great point of interest about them, however, is, that the bird with dark back and light belly is really in the condition which is quite common in a number of birds, especially ducks and wading birds, where it must act as a means of concealing the bird-just as it does in the painted model. Of course, there are vast numbers of birds not so shaded, but it is possible to explain the darker and lighter colouring, in various arrangements seen in birds, as helping to produce concealment or disappearance from view, when the habits and natural surroundings of the bird are known. So, too, with many hairy quadrupeds (mammals, or " animals," or "beasts," as they are often called). The white hair under the tail and about the rump, helps a running animal to escape the vision of its pursuer-blending, as Mr. Thayer shows that it does-with the white colour of the sky-line. In the case of fish-especially fresh-water fish-the dark back and light belly are very common, and although they do not help to conceal the fish when seen from above, swim- 
ming over a light-coloured river-bed, yet when looked at by other fishes or by otters in the water, the effect of the light from above on this disposition of dark and light tints on the fish's body must be the same as that demonstrated by Mr. Thayer's "disappearing duck," and must often render the fish absolutely invisible, even at close quarters.

Mr. Thayer has pursued this subject during the past seven years, and last autumn he gave some interesting demonstrations in the Zoological Gardens in London. He showed a model of a white egret, which was but little noticeable when standing up clear against a bright, whiteclouded sky. The long plumes on the wings, developed in the breeding season, were shown (by putting them on and taking them off) to assist in causing invisibility, since they made the side of the body flat and concealed the shadow on its rounded underside. A similar birdmodel marked with strong black on the neck and legsthe rest being white-refused (so to speak) to shape itself as a bird at all, and looked at a distance of twenty yards like a bit of rock or stump of wood with a twig and dead leaf attached. The effect of different tones of brown cardboard cut into the form of a butterfly, when seen on different backgrounds, was shown; but the most interesting experiment was made with a black-green piece of cloth cut to the shape of a butterfly and fastened on to a sheet of dead-black cloth in the open air, in the presence of white cloud light of moderate brilliancy. At five yards one could see the outline of the dark-green butterfly-shaped piece; at fifteen yards one could just distinguish the edge separating the dark-green piece from the black cloth. Now Mr. Thayer stuck in the middle of the dark-green butterfly-wing a small circle of pure white (about one-third of an inch across). The effect was entirely to obliterate the previously visible edge; one 
could no longer see the dark-green area at all-one only saw a white spot on a continuous dark ground, the darkgreen and the black were merged into one. That is no doubt due to the powerful stimulation of the sensitive "retina" of the eye by the white light of the spot; the feeble stimulation by the dark-green and black, though these remain physically as distinct from one another as before, ceases to affect the brain, which is, as it were, entirely occupied with the strong white spot. This, according to Mr. Thayer, is the value to butterflies and other animals of a violently contrasted white spot or band on a dark general colouring. The fringe of white dots and connected white flakes nearer the centre of the wing-common on the wings of butterflies-has, similarly, the result of rendering the wing-outline imperceptible and the butterfly invisible. Many such relations of colour spots and bands, as well as of dark and light markings, have been elucidated by Mr. Thayer, and will be illustrated by coloured drawings in the book which he is preparing on the subject.

While it is the fact that Mr. Thayer has thrown new light on the colour-protection and invisibility of animals, it must be remembered that there are other explanations of certain cases of brilliant colouring in animals besides that which he has so well illustrated. "Warning" colours, recognition marks, and sexually attractive colouring all certainly and demonstrably exist in well-known and wellstudied kinds of animals. It is very possible that some of these colour-markings have been produced by a slight change in what were previously "concealing" patterns or colour-markings. The tendency of the human observer is to regard any colour, spot, or pattern on a bird, fish, beast, or insect as a "mark" or distinguishing "sign." We examine these things at close quarters, and do not, unless we reflect a good deal on the matter and experi- 
ment with the object, realise that what is a mark of distinction or recognition when seen at a few inches' distance may be an illusive and obscuring colour-scheme when seen at a distance of some feet, and in natural and habitual surroundings. It is not unlikely that we shall arrive at definite knowledge of the psychological "sight interpretations" of animals by a further study of this subject. It is in the highest degree probable that the retinal picture produced in an animal's eye by certain spots of colour, shade, and light exhibited by another animal, are not interpreted by the receptive animal in the same way as they would be by a scrutinising, inquiring, reasoning man, even one who is what we call a "savage." Moreover, though many English naturalists have travelled and seen "life and light" in the sunny regions of the earth, there are few students of the colour-markings of animals in our museums, especially in great cities, who have adequate experience of what colour-markings really can effect in the way of concealment and illusion when light and surrounding objects are as they are, in the tropics or sub-tropical regions. It is a fashion nowadays in the best-provided museums of natural history to exhibit stuffed beasts, birds, and insects in what are called "their natural surroundings." The fatal objection to such exhibitions is that were the beasts, birds, and insects placed in their most usual "natural surroundings," they would be invisible!

It is the merit of Mr. Thayer to have drawn attention to these considerations, and to have carried out some interesting demonstrations of the more frequent significance of colour-markings as means of concealment and illusion than had been recognised before his work. At the same time, it is not possible to consider the yellow and black livery of wasps, of certain evil-tasting grubs, and of poisonous salamanders as anything but a "danger- 
flag," a warning to other animals that the yellow and black animal had better not be bitten and tasted. So the previous experience of animals who have bitten yellow and black creatures is appealed to, and ensures the safety of the yellow and black gentry from tentative bites which would kill them. Other recognition marks by which illtasting, nauseous butterflies are distinguished, and in consequence of which they escape attack, and, not only that, but are "mimicked" (as the yellow and black poisonous wasp is mimicked by some innocuous flies which thus escape attack) by other pleasant-tasting butterflies which fly with them, are considered by Mr. Thayer to be wrongly interpreted as recognition or "warning" marks. He shows, with more or less success, that the markings of the butterflies known as Heliconiæ are effective as concealment, and is therefore inclined to deny their value as "warning" marks, serving to indicate a noxious quarry best left untasted.

It is, of course, quite possible that what are "concealment markings" when viewed by an aggressive bird or lizard at a distance, may be recognised as "warning marks" when seen by the same observers at close quarters, and it is also possible that the latter may have become the more important or only important result of the colour marks of a given butterfly which were once useful as "concealment." The possible change of significance of colour spots and markings in wild animals may be illustrated by the effect on human beings of the burglar's crêpe mask. At the present moment probably the most prominent result of the appearance in a house full of people in the dead of night of a man with a crêpe mask over his face would be terror to those who saw him. The mask would be interpreted as a "mark" or "sign" of evil, not to say violent intentions on the part of the masked man. It would be a "warning colour," and most un- 


\section{PROTECTIVE COLOURING IN ANIMALS 3 I 3}

athletic individuals would severely avoid it; in fact, retire from it in alarm. But actually, the burglar's mask-as possibly some noxious insects' distinctive markings-was not invented for the purpose of causing alarm. Far from it! The burglar, or nocturnal malefactor, dons his crêpe mask in order to cover the white glitter of his face, and so to escape observation. In origin it is a protective coloration leading to invisibility, and only secondarily has it become a "warning colour" or "mark" at close quarters. There will be much more ascertained, and much instructive discussion as to the colours and markings of not only animals, but also of flowers and foliage, before this wonderful subject is thrashed out. I have only been able here to indicate its outlines. 


\section{XXXIV}

\section{HOP-BLIGHT}

- OPS have for many years now been a very un1 certain investment for those who, in England, devote capital to the growing, drying, and marketing of this crop. In some years a fortune may be made, in some years a dead loss, in many a bare return of expenditure. Hence, it is not surprising that English hop-growers should wish for legislation which shall make their business more secure by taxing the hops produced in other countries, and imported by our brewers. The whole subject of "hops" is a very complicated one. It is the fact that every plant and animal cultivated by civilised man has led to the accumulation of an astonishing amount of detailed knowledge and experience in each case, and that there are increasing difficulties and surprises in regard to varieties, and the competition of new supplies brought from all quarters of the globe. New areas of cultivation, new methods of transport, new fashion and taste continually disturb, and even destroy, old-established industries. It is for statesmen to consider how far the remorseless current of unforeseen changes should be checked and manipulated, so as to prevent disaster in the old-established and flourishing industries of the countryside.

The hop (called Humulus lupulus by botanists) is a native of this country, and of the more temperate parts of 
Europe. The Greeks and Romans never made "beer," and were unacquainted with the use of the hop. More than a thousand years ago the German and Scandinavian peoples made use of various fragrant herbs (sweet gale, bark of tamarisk and oak) to flavour the sweet beer which they brewed from malted grain, just as borage, cucumber, and other plants are still used to flavour "cups." Wild hops were used, amongst other herbs, for this purpose, and gradually-but only gradually-became the favourite source of flavour. The hop owes its selection not merely to its bitter tonic quality, but also to its wonderful and most delicate perfume. Not only that, but the hop is found to be effective in checking continued fermentation and souring-and also to have a narcotic sleep-producing quality, for which it is still used medicinally. Distinct chemical compounds are found in hops to which these several properties are due. A warm "hop-pillow"-a pillow stuffed with dried hop-flowers-has given, and still gives, sleep to many a wakeful countryman. The older use of other fragrant plants in the making of beer survives in some foreign beers, such as the Norwegian ale, the beer of Louvain, and the "green" spruce-beer of Jena.

Hops were first cultivated with a view to obtaining varieties which would furnish abundant and large, wellflavoured flower-heads. The flower-heads are "cones," consisting of numerous minute flowers, protected by overlapping green-coloured scales or bracts. The cultivated hop was brought to this country in the time of Henry vIII, and the cultivation of hops in hop-gardens and the skilful drying of the flower-heads in large bulk was commenced, and regulated by law. The male or pollenproducing hop-vine is distinct from the female seedbearing hop-vine; it is the female flower-cone which carries the valuable fragrant and resinous products which the brewer desires. Hops are artificially propagated by 
root-cuttings, and it is interesting to note that the hopgrower finds that it is not desirable to allow the female flowers to be fertilised, since, although the hops weigh more after the setting of the seed, the valuable extractive substances contained in the flower are diminished, used up in the growth of the seed. Hence, often only one male hop-vine to every 200 female hop-vines is allowed in a hop-garden.

It does not follow because a plant is a native of a given

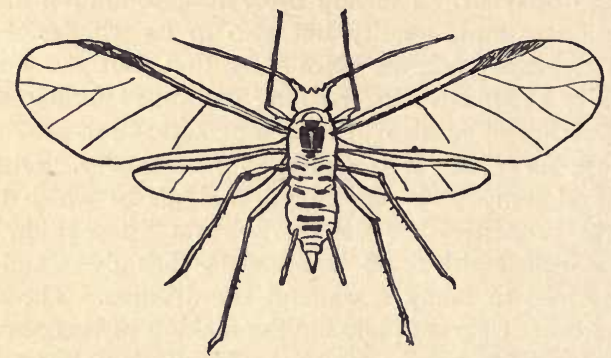

FIG. 55.-Early winged female hop-louse, produced viviparously by the first generation of daughters of the "Foundress," Fig. 58. These winged females migrate from the plum 'tree, where they were born, to the hop-vines by aid of their wings, and produce viviparously the form drawn in Fig. 57 .

country that it can be easily cultivated anywhere in that country, or that its finest cultivated varieties will be hardy. Only a few limited territories (owing to the nature of the soil, climate, and exposure) in Germany (chiefly in Bavaria), and in Kent, Sussex, Worcestershire, and Herefordshire, seem to be really favourable to hopgrowing in Europe. Certain parts of the Pacific coast of the United States have of late years proved a very successful ground, although hops were introduced from Europe and first cultivated with considerable success in 
the State of New York. The same dangers and troubles attend the hop-crop in all these regions. These are blight, red-spider, mildew and mould, besides several less important insect pests. The hop-blight, or "black-blight," is a plant-louse or aphis (Fig. 55) like the rose-aphis, and does great and increasing damage to the hop-crop in England, destroying the young and tender shoots in the months of June sand July. In I 882 the hop-crop was reduced from $459,000 \mathrm{cwt}$. (of the preceding year) to

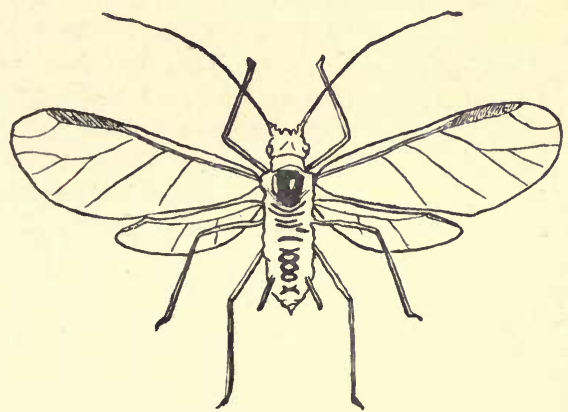

Fig. 56.-Male hop-louse, not appearing until late autumn.

I I 5,000 cwt. by this insect, and the wages paid for hoppicking from $£ 350,000$ to $£ 150,000$. These figures give an idea both of the damage done by blight and of the amount and value of the annual crop, for the mere picking of which so large a payment is made. Red-spider is a small mite or acarid which has done a good deal of damage in Kent. But mildew and mould are more serious. These are due to a delicate, thread-like kind of fungus, which spreads on the leaf. Many kinds are known in various parts of the world and on various plants. They may grow on one kind of plant without doing injury to it, 
but if they get on to another, cause deadly destruction of the foliage. It was an otherwise harmless mould, or leaffungus, which destroyed the coffee plantations of Ceylon. It had lived in the Ceylon forests on other plants without attracting notice; but when the coffee tree was introduced and cultivated in large areas, this little fungus seized on it, grew with terrible activity, and received the name "vastatrix" from the botanists who traced its history, and showed that it was the destroyer of the coffee plantations.

Hop-growers are constantly contending with these pests

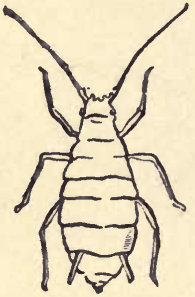

Fig. 57.-Ordinary wingless female hop-louse, multiplying parthenogenetically throughout the summer.

in the same way as other growers of crops have to contend with similar pests, but the hop-growers have the more difficult and delicate "patient" to steer through its diseases. The finest kinds of hops are not robust; it is a chance whether or no they will suffer from a wet and cold season, or other irregularity of climate, to such a degree as to fall ready victims to blight and mildew. Yet they pay better, provided the season is favourable, and so the grower risks planting the fine, delicate variety instead of being content with the more certain but smaller profits yielded by a more robust variety of hop. The hop-lice, or blight insects, are destroyed by washing with soft soap and quassia-a process requiring, even when a machine is used, a good deal of care and labour. Mildew and mould are destroyed and also prevented by dusting the hop-vines in hot summer weather with finely powdered sulphur. But both diseases can be combated by keeping the source of infection away from the hop-garden. The mouldfungus can be checked by burning all leaves and plants 
attacked by it within the hop-garden. If the infected leaves are left to rot they carry on the parasitic fungus to a new season.

An interesting fact has been discovered about the hopblight aphis (called by zoologists Phorodon humuli). It appears that the winter brood of this little insect (when the hop-vine has died down) deposit their eggs on the bark of the sloe (the wild plum), and also that any cultivated plum trees serve them for the same purpose. When the hop is dead they must of necessity get nourishment and shelter from the plum tree. Clearly, then, if you can keep all plum trees at a distance of half a mile from your hopgarden you will render it very difficult, if not impossible, for the blight aphis to carry on from season to season. It will rarely, if ever, travel half a mile, and not in any number. But hop-growers have not always the control of the cultivation for half a mile around their hop-fields, though large growers should be able to acquire it. The skilful grower even finds it useful to leave one or two plum trees in the hop-field, so as to attract the winter brood of the blight aphis to them, and then he falls upon the devastating but minute rascals with quassia and other poisons, and ensures their destruction. The increase of plum orchards in the neighbourhood of hop-gardens is probably a chief cause of the increased loss by hop-blight of late years in Kent.

The hop-louse has other enemies besides the grower. These are the lady-birds (less prettily called "lady-bugs"), which feed greedily on the parasites, so that when the hop-grower sees plenty of them on a hop-vine he does not trouble to wash it. And there are other predaceous insects which tend to keep the hop-lice down. Cultivation and excessive production have resulted in putting, as it were, too heavy a task upon the natural enemies of the pest, whilst the more delicate but valuable varieties of 
hop cannot withstand the attacks of blight, which less valuable varieties would tolerate without fatal injury.

Another complicated and difficult problem for the hop-grower is the "curing" of the hops when gathered. $\mathrm{He}$ has to arrange to grow a number of varieties which will not be all ready for picking at the same moment, so that the hop-pickers may be employed for some six weeks, and gather each kind at the exact time of ripeness. Then the gathered hops have to be "dried" and "cured." In Germany (where the highest-priced hops are produced) small cultivators dry them in the sun, and they are "cured" by the purchaser, but in England they are dried in kilns (called "oasts" in Kent) near the hop-grounds. They are cured with sulphur fumes on the spot as soon as dried. The object of the drying and curing is quickly to get rid of the water, which forms 75 per cent. of the weight of the green flower-heads, but is reduced by drying to Io per cent., and to destroy the "mould" (fungus) which may be present, and to keep the hops free from new access of mould by the slight deposit of sulphur fumes on their surface. The drying and fumigating require a great deal of skill, and a fine crop may be injured or even rendered worthless by want of care, rapidity, and judgment in treating the freshly gathered flower-cones. It is said that it takes years to acquire the art, and that skilled hop-curers are more difficult to obtain than formerly.

The natural difficulties and fluctuations with which the English hop-grower has to contend are made far more serious by the fact that he does not know what will be the yield of the American and German hop-plantations, and so cannot prepare beforehand for the demands of the market. It appears that ice-storage is now being made use of in some districts to hold over any excess of produce of particular kinds of hop beyond the special demand for those 
kinds. But a formidable source of trouble exists (and, it appears, must always exist) in the enormous changes and expansion of the brewing industry in all parts of the globe. It is actually the case that there has been a greatly increased and unforeseen demand for hops of less highly developed aroma, for the purpose of brewing light ales with little of the perfume given by the finest and hitherto most highly priced hops. So that, having expended skill and money to produce the finest hops, and having been favoured by the weather, a grower may find that his pains have been thrown away, and that there is a sudden falling-off in the demand for the beautiful highpriced crop which he has gathered in. There is no remedy for these world-wide fluctuations in the market, and the only way in which the grower can protect himself is by combining with others to procure information from every part of the world as to the probable production and the probable demand of the various qualities of hops a year or more in advance of his planting. More has been done in America and in Germany in this way than in England, and it is probable that the future success or failure of hop-growing in this country depends more on the possibility of obtaining correct information in regard to the tendencies of production in all hop-growing countries, and in regard to the demand in all the brewing industries of the world, than on anything else.

This brief sketch of the hop-growing industry is sufficient to show what a very difficult problem is before those who desire to take legislative measures for the preservation of the old industry of the hop-garden in this country. But it must not be at once assumed, because the case is a difficult and complicated one, that nothing can be done, and that the beautiful hop-vines and the finest hops are necessarily to be banished from the English soil. 


\section{$\mathrm{XXXV}$}

\section{GREEN-FLIES, PLANT-LICE, AND PARTHENOGENESIS}

HE minute "green-flies" which attack all kinds of
plants, and among which are ranked the hoplouse or hop-blight, the rose aphis or green-fly of rose trees, the woolly blight or aphis of apple trees and pear trees, and the terrible vine-killer-the Phylloxera vastatrix - form a special group of bug-like insects known as the Aphides. They have soft cylindrical bodies, six legs, sometimes two pairs of transparent wings, sometimes none, and a sharp beak (in some kinds this is one and a half times as long as the body), with which they prick the soft parts of plants, when they suck up the juices which issue from the wound (Fig. 59). There is in the temperate regions of the world a special kind of aphis or plant-louse peculiar to each of many kinds of flowering plants, including most trees. A very complete, illustrated account of the kinds or species of British aphides, amounting to some two hundred, was produced by the late Mr. Buckton, F.R.S., and published by the Ray Society.

There are many facts of extraordinary interest about these tiny swarming insects. In the first place, they are closely related to the minute scale-insects or Coccida, several species of which produce the celebrated lac of lacquer-work and the dyes known as lake, cochineal, and 
kermes, the latter a dye manufactured in South Europe and used to colour wool and cloth crimson before cochineal reached us from Mexico. The Coccide include also the "mussel-scale" and other destructive diseases of fruit trees. A beautiful purple colour can be extracted from crushed masses of some kinds of aphides (as well as from Coccida), and has been used as a dye. The aphides have very generally a green colour, like many insects (caterpillars and leaf insects) which pass their lives upon green leaves and feed on them. It is often supposed that this green colour is merely the green colouring matter (so-called chlorophyll) of the leaf, taken up by the insects

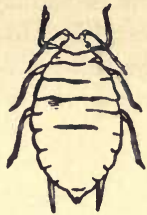

FIG. 58.-Foundress or stock-mother of the hoplouse: the individual hatched from a winter egg, laid on the bark of a plum tree, who produces viviparously a wingless virgin brood. That brood produces wing-bearing young, which fly off to the hopplants. in feeding on the leaf. But this is not so; it is a peculiar substance derived in a crude state from the plant-juice, but digested in the stomach and completed in the insects'

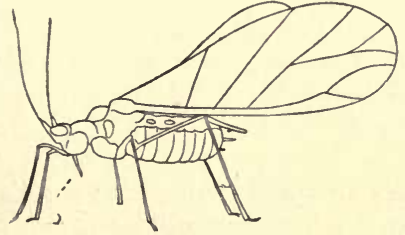

FIG. 59.-Side view of winged viviparous female of the hop-louse. $b$, the stabbing beak. trees, as to look like masses of cotton wool adhering to the twigs of the tree, are of this nature. Then, again, the aphides produce curious secretions, often in great abundance, which surround them as the lac surrounds the lac-insect. The threads which are produced in such abundance, by the woolly aphis of apple

blood and tissues. 
Another curious production of the aphides-common on the leaves of elms and other trees infested by them-is known as "honey-dew." It is sticky and sweet, and was supposed by old writers to have distilled from the stars, or otherwise to have dropped from heaven. It is this sweet secretion which has led to the establishment of a most

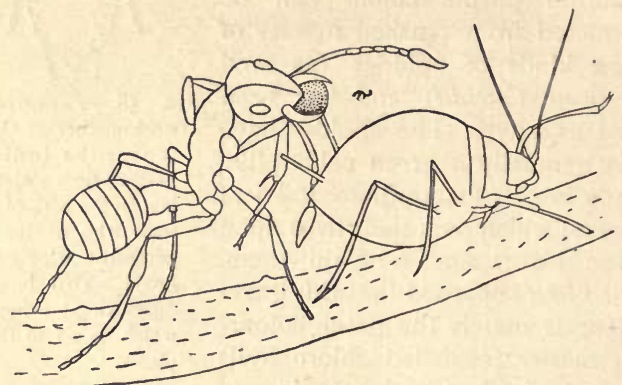

Fig. 60.-An ant "milking" a "plant-louse " or "green-fly" for honeydew. The drop of honey-dew is seen exuding from one of the two long tubes or spouts (called "cornicles") on the back of the plant-louse at $a$. These spouts are seen at the hinder part of the body in the drawings of the hop-louse (Figs. 55 to 59). The ant is causing the aphis to pour out its honey-dew (in fact "milking" it) by "drumming" on the body of the plant-louse with its clubbed antennæ, and has taken the drop of honey-dew between its jaws. This drawing was made from life by the late Mr. Buckton, F.R.S., a great student of these creatures. The ant is that kind known as Myrinica rubra. The plant-louse is the Aphis sambuci or blight of the elder-tree.

curious friendship between ants and aphides, or plant-lice. It has long been known that an ant will approach an aphis, and tickle it, when at once the aphis exudes from its cornicles (see Fig. 60) a drop of sweet honey-dew, which the ant swallows-just as a man may milk a cow and drink the milk. And the resemblance goes further, for the ants take possession of certain aphides, and keep 
them either underground or in specially constructed chambers, where they can gain ready access to them and "milk" them for honey-dew. There has been a certain amount of exaggeration in the description of these facts by some of the older writers; but it is undoubtedly true that some species of ants keep special flocks or herds of aphides, and feed on their sweet secretion.

Other small insects nourish themselves on the enormous swarms of plant-lice in a less gentle way, but a way which man is very glad to see in active operation, namely, by biting them and sucking out their soft entrails-thus destroying them in great numbers. The lady-bird beetle is especially active in this matter, both when it is a grub and on attaining its adult form. A trustworthy observer saw as many as forty aphides consumed by a lady-bird in an hour. Where the plant-lice or aphides abound, there come also in countless swarms the beetles known as lady-birds. In the year I 869, such a cloud of these beetles passed over and settled on the fields and gardens of Kent, Sussex, and Surrey, as to cause something like terror; it was impossible to walk in the lanes without crushing hundreds under foot. But the little lady-birds are not like the terrible locust, which appears in millions and devours all vegetation before it; on the contrary, they are what are called "beneficials," and come solely to feed on and destroy the plant-lice of the hops, plum trees, and apple trees. A first-rate hop crop in the year 1870 was the consequence of the abundance of lady-birds in 1869. It is this beneficent activity of the lady-birds which has given them their name. In Italy they are called Bestioline del Signore, also Madonnine, and Marioline, and in France Bête à Dieu. In English they are "our lady's blessed bugs," which save the crops from destruction.

The exertions of the aphides in pricking the plants they infest so as to get at their juices lead to the 
growth of galls on the leaves, and also on the rootlets of many plants, and often the leaves become rolled up into bag-like bodies filled with aphides. Many trees and smaller plants are killed by these attacks, but it is probable that where the plants have not been rendered delicate by nursing and cultivation, and where the aphides are not a strange foreign kind, introduced by man's carelessness or by some rarely (if ever) occurring wind or flood, the aphides do not actually destroy any plants by their visitation, excepting the weaklings, and that their numbers are kept within bounds by their natural enemies the lady-birds and other such carnivorous insects.

We must now notice the most interesting of all the wonderful things which have been discovered about these tiny insects, which are even smaller than fleas. Any one who has a rose-garden and chooses to spend some hours a day in studying the "green-fly" can follow out the facts. They reproduce themselves-that is to say, propagate-with astounding rapidity. The great Linnæus, a hundred and fifty years ago, came to the conclusion, from his observation of one kind or species, that in one year a single aphis would produce a quintillion of descendants! Without insisting upon the exact numbers in different kinds of aphides, we may say that that is a fair indication of the rate at which they produce young. No sooner does a mother aphis produce some thirty or forty young, than in a few hours or days, according to the warmth of the season and the abundance of food, these young have grown to full size and themselves each produce the same number of young, and so on through the summer, and even into the autumn. Nineteen generations in sixteen weeks have been counted in some kinds of the plant-lice. Hence it is no wonder that these little creatures increase exceedingly and cover the leaves and shoots on which they feed; no wonder that they furnish 
a plentiful nourishment for the lady-birds which prey on them. But the most curious thing is this, that these abundant and rapidly reproducing broods of aphis are all females, and that they do not lay eggs, but extrude their young in a more or less complete state of development, that is to say, they are viviparous. They are all females! It is only late in the season that males are produced!

In fact, the summer broods of the "green-fly" and other aphides which do so much damage to rose bushes, hops, and other cultivated plants, are produced by females alone, without the intervention of a male. These minute insects present true instances of that very remarkable and interesting occurrence which is called "parthenogenesis," or virginal propagation. It is further a noteworthy thing that the virginal aphis mothers do not lay or deposit eggs, but that the young grow from the eggs inside their mothers (Fig. 6I), and are only extruded when they are complete little six-legged insects, capable of walking, and ready to feed themselves by stabbing the soft leaves of the plant on which they find themselves, and sucking up its juices. The summer aphides are spoken of as being both "viviparous" and "parthenogenetic." The words are really useful, and we cannot get on without them.

No case is known to medical men or to naturalists of the birth of young from an unimpregnated or virgin mother among what are called the higher animals-those which are classed as vertebrates, and include mankind, mammals, birds, reptiles, batrachians, and fishes. But though uncommon, this virginal reproduction (or "parthenogenesis") does occur constantly in a very few kinds of small insects and in some small shrimp-like creatures. It has excited the greatest interest amongst naturalists from the early days when it was first observed until the present, and it has been very carefully studied in the past thirty years. 
In order to appreciate this matter it is necessary to know the chief facts about the ordinary process of reproduction in animals and plants. All animals and plants are built up of minute particles of living matter called "cells" (see p. 170). Really, these are not cells, or hollow boxes, or cases. We use the word "cell" for the contents of a cell. Each is a droplet of protoplasm or living matter lying in a small or large envelope or case of dead matter which it has produced around itself (Fig. 6I). Observers using their microscopes saw at first only the case, and called it a "cell," and the word "cell" is now used almost universally for the soft stuff within the cell (see p. 173). Each soft cell of "plasm" or "protoplasm" has a very special structure. The existence in it of a central kernel, or "nucleus" of peculiarly active substance, is the most obvious feature. These "cells" are so small (for instance, those which build up the human body) that from one to two thousand could be placed side by side on a line an inch long. They are the "units" which make up the body of an animal or plant, just as bricks and planks and rods make up a building constructed by human contrivance. Two most important things about them are-first, that each is always the seat of chemical activity, absorbing liquid material, changing it and either fixing it or throwing it out in a new chemical condition; and, second, that as a result each cell grows, and after a very little growth divides into two. This "dividing into two" is immensely important, for in this way the number of cells forming a very young or small animal or plant is increased from a few thousands to many millions whilst the organism grows. And not only that, but we find on tracing the young animal or plant back to its beginning as an individual that it actually started as a single cell. The germ of every living thing, then, is a single nucleated particle of protoplasm-a cell which we call the "egg-cell," because 
"eggs" are merely shells and packing to hold and protect this all-important egg-cell.

Every individual flower, tree, insect, snail, fish, and man started as a single egg-cell, which became detached from the mother's body. Take the case of a common marine animal, the star-fish. At the breeding season, early in the year, the female starfish discharges thousands of these egg-cells into the sea-water. Each floats separately in a delicate case of its own. Before any one of those floating egg-cells can commence to divide so as to build up a new mass of cellsa new young star-fish-it must undergo the process of "fertilisation." That is to say, its substance must fuse with that of a "sperm-cell." These "spermcells" are discharged into the sea-water in countless thousands by the male star-fishes. They are excessively minute, actively wriggling threads, swollen out at one end to form a little knob, the "nucleus" of the sperm-cell (see p. I34 for figures of the spermatozoa, and eggs of the oyster). The water is rendered cloudy by the abundance of these microscopic filaments, which are called "spermatozoa." One sperm-cell, or spermatozoon comes into contact, in the sea-water, with each of the discharged floating egg-cells. It burrows into it and fuses or 
melts and mixes with the substance of the egg-cell. The whole process is easy to watch with a microscope, and I am writing of what $\mathrm{I}$, in common with many others, have actually seen.

The egg-cell after this process consists really of the substance of two equal cells-the egg-cell and the spermcell-completely fused so as to form a single cell, having a single "nucleus," which has resulted from the fusion of the nucleus of the egg-cell with that of the sperm-cell. Now, and not before, the egg-cell can divide, take up nourishment, and continue to divide and grow, so as to form a constantly increasing mass of young cells, a young animal which gradually assumes the form of a star-fish. All animals, and plants, too, reproduce themselves in this way. When the animal or plant is not aquatic in its habits the sperm-cell and the egg-cell cannot be discharged and take their chance of coming into contact with one another outside the parent's body; the spermcells are, in such cases, received into a chamber of the egg-producing parent's body, and there the fusion of the egg-cells with them, one sperm-cell to one egg-cell, takes place. Parthenogenesis then consists in the omission of the fusion of a sperm-cell with the egg-cell. The eggcell develops, divides again and again, and produces the young animal without the addition to it of a sperm-cellwithout, in fact, being "fertilised," as it is called. That is what happens in the summer broods of the little plantlice or aphides (Fig. 57). When, however, the cold weather comes the virgin mothers suddenly produce two kinds of young-males as well as females-and then the solitary winter egg, which the late autumn females lay to last through winter until spring, is fertilised by a sperm-cell derived from the late produced autumn male (Fig. 56) in the ordinary way.

Another parthenogenetic animal is the rare little fresh- 
water shrimp called Apus, which goes on multiplying in this manner in wayside ponds for years, thousands of female individuals being produced in successive seasons, laying their eggs and carrying on the race for an indefinite time until at last-one fine day-we do not know why then and not before, that rare creature a male Apus is hatched. Why these and one or two other such small shrimps and insects are able to set aside the almost universal law as to the necessity for fertilisation of the egg-cell by a sperm-cell, naturalists have not yet found out. It is quite certain that these exceptional creatures have been derived from ancestors which had their eggs fertilised in the regular way, and that this elimination of the male is a special device, an innovation.

There are incomplete attempts at it in other insects. Thus it has been discovered that the queen bee produces only females from the eggs which are fertilised before she lays them. When the stock of sperm-cells which she received from a drone in her nuptial flight is exhausted, or if we carefully remove by a painless operation the internal sac in which they are stored, the eggs are no longer fertilised, but they are not rendered sterile or sabortive. They develop into drones! And drones or male bees are produced in no other way, and only drones are so produced, never worker-females (so-called neuters) nor queens.

Another curious fact is that in rearing moths in captivity some naturalists have quite unexpectedly found that when they have hatched out female moths from the chrysalids and kept them from the moment of hatching quite apart from the male moths (which are of another size and colour, and easily distinguished), these females will sometimes lay eggs-unfertilised eggs-which give birth to caterpillars, which feed and complete all their 
changes. The second generation of moths so produced are male and female, but the females, being kept apart again, produce a parthenogenetic brood, and the process has been repeated to a third generation. These instances are very rare. The remarkable thing about them is that, apparently, the parthenogenesis is only due to the experimental interference of an entomologist, and that unless some such accident had befallen the moths, the eggs would have been fertilised in the usual way, since there was no deficiency of male moths. These facts have led to many interesting speculations, and are particularly curious in regard to the inquiry as to what determines the sex of offspring, about which sensational announcements are sometimes made in the foreign correspondence columns of our newspapers. Here we find the parthenogenetic eggs of the moths producing both males and females, those of the aphides and the pond-shrimp producing predominantly females, and those of the queen bee producing exclusively males (drones). Biologists have not yet arrived at a solution of the problem raised by these divergent results.

It is necessary, in regard to this subject, to remember that many lower animals and plants can reproduce or propagate by separating "buds," or large bits of their bodies, built up of thousands of cells, and, therefore, not to be confused with the single egg-cell. The egg-cell is a cell specially prepared for fusion with a sperm-cell, necessitating-except in very rare instances-the union in the new individual or young of living material from two separate parental organisms, and, therefore, in many cases, from two widely separate lines of ancestry. A snippet, or bit cut from a begonia leaf, will produce a new individual plant; a bit cut or torn from a polyp will similarly give rise to a new individual : but the parthenogenetic egg is not to be confused with these masses of 
cells. It is a true egg-cell which might have been fertilised, and it is found in animals such as insects and crustaceans, which are more highly elaborated in structure than any which, like the polyps and zoophytes, multiply by buds and cuttings. 


\section{XXXVI}

\section{THE DEADLY PHYLLOXERA}

I $\mathrm{T}$ was only after long and patient investigation that, the various broods of the terrible Phylloxera which between 1868 and 1888 , destroyed half the vineyards of France, became known, their relations to one another determined, and the final cure for the devastation caused - by them decided upon and put into practice.

In all ordinary plant-lice or green-fly (aphides) at the end of the summer, the last parthenogenetic brood produces a generation of distinct males and females, which differ a good deal in appearance from the virginal broods of the spring and summer. Each female, after receiving sperm-cells from a male, lays a single egg, which consists of a fertilised egg-cell enclosed in an egg-shell. It is deposited in a safe place in a crack of the bark of a tree, or on the rootlets of some plant, and remains unchanged through the winter. In the spring from every such egg hatches a single female aphis, which feeds and increases in size. In a very short time (a week or so) this solitary female (Fig. $5^{8}$ ) proceeds to produce, without male intervention, young which grow from true egg-cells which are not laid but remain inside her. The young are born or pass out of her as small six-legged insects. They feed and grow up, and in turn produce "parthenogenetically" and viviparously broods of young like themselves. The first 
female thus hatched from the winter egg is called a "foundress," or "stock-mother," because she starts a whole colony of young which, by virginal propagation of successive broods, may number many millions in a season. These are known as "virgin-mothers" (Fig. 57), and eventually their later generations always produce males and females, so that we distinguish, in the course of a year, four sets of aphides, starting from the egg, namely (I) the foundresses, (2) the numerous generations of virgin-mothers, (3) the males, and (4) the egg-laying females.

In different kinds of plant-lice any of these "sets " may be either winged or wingless (Figs. 55, 56, 59); many generations of the virgin-mothers are wingless, but not all, in all species. According to the species or kind of aphis and its requirements in regard to the plants on which it feeds, wings are developed so as to enable the aphis to fly from one tree or locality to another, or are not developed if the aphis has to remain where it was born. The whole series of successive broods of some kinds of aphis remain on one plant and about the same part of it, and then there is little need for wings. Others have their summer broods on the twigs or leaves, but the later broods descend in winter to the roots of the same plant. The woolly aphis of the apple trees and pear trees behaves in this way; other species again produce a late-winged brood, which leaves the plant on which its parents were feeding, and travels some distance to the twigs or to the roots of a quite distinct kind of plant to produce an autumn brood, and from these the final males and females are born, and the winter eggs are then deposited. The hop-louse leaves the hop when the hop-vine dies down in autumn. The abundant wingless form (Fig. 58) of which there have usually been ten generations, produces at last a winged " migrant" brood (Fig. 59) which flies away to plum trees and sloe bushes, perhaps a quarter of a mile distant. There the 
migrants produce wingless females on the plum tree. They are followed to the plum trees by a final migrant brood from the dying hops which are males-the first yet seen (Fig. 56). The males fertilise the wingless females born on the plum tree-and the latter lay each one fertilised egg in the crevices of the bark of the plum tree near the young buds. Winter now sets in: all are dead except the eggs. In the following late spring a foundress hatches out from each egg so deposited. The "foundress" (Fig. 58) in this species, the hop aphis, is wingless. She produces parthenogenetically and viviparously a brood of wingless females. They similarly produce on the plum tree a third generation of virgin females, but these have wings! (Fig. 55). They fly back to the hop-vines, which are now well risen from the ground and offer abundant juice to the wingless virgin brood which escapes from the winged migrants as soon as they have settled on the hop, and feed and grow and produce new wingless broods (Fig. 57) in rapid succession.

The phylloxera of the vine is a plant-louse or aphis, which exhibits an interesting adaptation of winged and wingless broods to the requirements of the insect's nutrition and multiplication. A "foundress" hatches from an egg on the bark of the vine where it has passed the winter. It proceeds to attack the young leaves and to produce a brood of young. The leaves of the vine when thus attacked swell up and produce galls, in which the young phylloxera are enclosed, and there the phylloxeras continue to multiply, producing more galls and thus destroying the leaves. Some of the young broods now crawl down the vine to its roots; others stay on the leaves and continue their destructive work there. There are several varieties of form and size amongst these broods. Those which go to the roots attack the rootlets and produce knobs and swellings on them, leading to their destruction as feeding 
organs. Meanwhile the root-phylloxeras multiply exceedingly, and those on the leaves are still feeding and multiplying. From one foundress mother as many as twentyfive millions are produced in six months. At last in the autumn the root-parasites produce a winged generation of virgin-mothers, which come up from the ground and fly away to other vines, upon which they produce males and females. These females each lay a fertilised egg on the bark of the previously healthy vine, and so the infection is spread. The root-infesting forms continue to multiply, and in warm climates there is no cessation of this process even in winter.

This parasite-the Phylloxera vastatrix-was introduced with some American species of grape-vinebrought over as experimental samples from Coloradoabout 1864 . In its native country it does comparatively little harm, for the roots of the American species of vine are, though attacked by it, not seriously injured. They have the property of throwing out new rootlets when those already existing are punctured and injured by the phylloxera, and so are not killed by the attack, as is the European grape-vine.

The introduction of this deadly parasite to Europe was a mere chance, due to ignorance and stupid want of supervision of importations on the part of the Government, such as is common in this country, though less so in France and Germany-part of the blind mixing-up of the nicely adjusted products of all parts of the earth which civilised man is always bringing about with disastrous and terrifying results. In twenty years France lost 400 million pounds in consequence; three million acres of vineyards were destroyed. Other countries-Germany, Italy, and the Cape-also suffered. All sorts of remedies were suggested and tried, such as the application of poisons to the roots and the sinking of the vineyards 
under water. Gradually the only effective method of dealing with the case has been established. The old European vine-stocks or standards have been grubbed up in all but the very choicest vineyards, and American vines have been planted in their place. On to these have been grafted cuttings of the local French vines, and they have taken kindly to their new conditions. The produce of the French vineyards is now greater than it has ever been. It had fallen from an annual yield of $1,300,000,000$ gallons to $650,000,000$-but in 1900 it had risen again to a yield of more than $1,400,000,000$ gallons.

This history is a striking instance of the vast importance to civilised communities of a knowledge and control of even such minute living things as the plant-lice, and of the extraordinarily large results which obscure living things may produce. It must tend to convince reasonable men of the importance of accurate knowledge as to living things and of the necessity of expending public money in constantly improving and extending that knowledge.

An ingenious illustration of the enormous fecundity of the plant-lice occurs to me as worth giving in conclusion. The late Professor Huxley-a careful and trustworthy authority - calculated that the produce of a single aphis would, in the course of ten generations, supposing all the individuals to survive, "contain more ponderable substance than five hundred millions of stout men; that is, more than the whole population of China." And this calculation is held by some authorities to be below rather than above the mark ! 


\section{XXXVII}

\section{CLOTHES MOTHS}

THE way in which the lives of all animals and plants 1 are interwoven with that of other animals and plants, often in obscure and unsuspected ways, comes home to man when he contemplates the numbers and variety of living things which exist with him and upon him - that is to say, at his expense and to the detriment of the stores which he accumulates, the clothing with which he covers himself, and the buildings which he constructs. Man not only has carefully taken a number of animals and plants in hand and cultivated them as food-givers, as sources of clothing, and other useful material, but, much to his annoyance, he finds, per contra, that other animals (and plants, too), with similar selfseeking habit, make use of him in his turn, and of his belongings, with a complete disregard of his convenience, treating him and his arrangements as so much available "food-stuff," and showing no atom of respect to him as the lord of creation. Just as in dealing with the more deadly attacks of disease-producing parasites, so in meeting the destructive invasions made by his fellowcreatures of all sizes and kinds in search of food and shelter-man has to be continually on the alert, and to wage a constant warfare, unless he will consent to see himself and his possessions moth-eaten, fly-blown, worm- 
burrowed, reduced to fragments and powder. And this warfare he has incessantly carried on with increasing skill and knowledge from the earliest times of which we have any record.

The sparrow and the rat, of which there has lately been much talk, are examples of fairly large, easily detected enemies of this kind. The almost ultra-microscopic bacteria-similar to those which produce disease by multiplying in the living body-are examples of the most minute living pests which injure man by causing sourness, putrefaction, and destructive rot in his food and stores. Every year civilised man is gaining greater knowledge of these "ferment organisms," and vastly increased skill in preserving his possessions, such as food and drink, from the attacks of their ubiquitous swarms. Between the larger depredators, such as birds and rats, and the smallest, such as the microscopic bacteria and moulds (to whom alone putrefaction is due, and without whom it would never occur), there are a host of small troublesome creatures, which belong chiefly to the group of animals called "insects"- beetles, moths, flies, and bugswhich give man incessant occupation in warding off their attacks upon his food, his clothes, his furniture, his buildings, his crops and fruit trees, and his domesticated animals. The study of these things and of the means of grappling with them is the fascinating occupation of those who are called "economic" zoologists and botanists. Of course, in order to carry on their inquiries successfully they have to bring to bear on the questions they investigate as complete and thorough a knowledge as possible of all the kinds of animals and plants, and of their ways of feeding, reproducing, and protecting themselves in natural conditions.

One of the most widely celebrated and anciently detested of insect pests is the clothes moth. It is the 
caterpillar of this moth which is objectionable-biting off, eating, and using to weave a case the hair of furs and the fine filaments of woollen fabrics. Not every one is able to recognise the clothes moth, which is a very small creature of a greyish-yellow colour. The wings when set for flying measure only half an inch in expanse, and when the moth is walking or at rest, shut closely to the body so as to give it an almost cylindrical shape, with an attenuated snout. Much bigger moths occasionally get into our rooms, but do no harm. These little clothes moths lay their eggs on fur or wool, and the caterpillars which hatch from them do the damage. The moths themselves have no jaws and take no food. But the caterpillar or grub, though soft and readily crushed, has a pair of very hard, minute, dark-coloured jaws, with which it works away, cropping the fur and wool on which it lives. The moths are seen in houses commonly between January and October, and it is, of course, the object of the victimised householder to destroy them before they can lay eggs, or, what is more practical, to keep woollen and fur clothes away from their reach. Things which are in daily use are not very liable to receive a deposit of eggs from the clothes moth, and as a rule the enemy may be kept at bay by daily shaking and beating the things in question, and hanging them up in the air. But coats, flannels, etc., which are hidden away, left quietly in drawers or cupboards, offer the undisturbed conditions which the clothes moth seeks. There is no safety for them unless they are wrapped up or shut in with a quantity of naphtol or of camphor, or, as is nowadays more usual, placed in a refrigerating chamber.

The little caterpillar which does all the damage is of a dull white colour, with a reddish head. It is remarkable for the fact that it makes a sort of movable tunic or case for itself out of the hair or wool which it crops, and it crawls 
about protected by this case. There are not many insects which thus construct portable cases for themselves when in the grub or caterpillar state of life. Such "cases" must not be confused with the very similar "cocoons" by which some moth-grubs surround themselves (as, for instance, the silkworm moth) when their growth is completed, and they become quiescent and hard, and are known as chrysalids. Such "cocoons" are constructed in the same way as the lining of the clothes moth's case, by threads of silk secreted by the caterpillar, but they are made once for all when the grub has ceased activity. The little clothes moth caterpillar, on the other hand, has continually to enlarge its tunic or case as it itself increases in size. There is a hole at the end, from which the head and three legs of the caterpillar emerge, so that it can crawl and feed freely. The outer surface of the case consists of cut lengths of the fibre on which the grub is living, and so is protective in resembling the surrounding material and hiding the minute ravager. It is easy enough for the little grub to add a bit to the case at the end from which its head protrudes, and, being very flexible, it can turn right round in the tube and put its head out at the other end and secrete a bit more there, cementing cut hairs to the outer surface. But in order to increase the breadth of the tube or case, the caterpillar has, from time to time, to undertake a formidable operation. It actually slits up the case lengthwise for about half its extent, and fills in the gaping space with new material; then it cuts up the opposite face of the same half of the tube, and puts in a new patch there. And after that, it has to treat the remaining half of the tube in the same way, making two more cuts, one opposite the other, and filling in the gap in each case as before. Students of these little creatures have amused themselves by changing the position of the caterpillar and its case, from fur or 
wool of one colour to fur or wool of another colour, and in this way the industrious caterpillar is made to work in different coloured fibre in successive enlargements of his case, so that it becomes a Joseph's coat of many colours.

An interesting fact about the movable case made by the clothes moth caterpillar is that the nearest thing in nature to it is the case made by the aquatic grubs or caterpillars of another kind of insects-the caddis-worms ("case-worms") which are common in ponds and streams. They show extraordinary powers in making their cases so that they balance nicely in the water, as the animal crawls along on the hottom of a pool, with his head and six legs emerging from one end of the case. Caddis-worms are of various kinds or species, and some attach to their cases little broken sticks, others minute empty snail-shells, others the fine green threads of water-plants. The caddis-worm becomes changed into a delicate fly, with transparent wings, just as the clothes-grub becomes changed into a moth-and it is an interesting fact that the caddis-flies, though they are classed with the Mayflies and such net-winged insects, and not with the moths and butterflies (the Lepidoptera, or insects with wings covered with dust-like scales, which give the colour and patterns to the wings), yet agree with moths in having some scales on the wings and with one kind of minute moth, namely, the clothes moth, in having grubs which make movable cases.

The clothes moth caterpillar was known to the Romans by the name Tinea, and is described with correct detail by the Roman naturalist Pliny. Modern naturalists have accepted this name Tinea as that of the genus to which the clothes moth belongs. There are thirty different British species of Tinea, of which four are guilty of attacking animal fabric, and so causing trouble 
to man. The one which builds a case and is the titular chief of the clan of clothes moths - "the" clothes moth, just as one may say "the" MacIntosh-is scientifically indicated by the name Tinea pellionella. The other three do not form movable cases when in the caterpillar stage, and attack coarser stuff than fur and fine wool. One of them is known as the "tapestry moth," because its caterpillar establishes itself in old tapestry and carpets, and burrowing into these thickish materials is concealed without the aid of any self-provided tunic or case. The name Tinea is often used by entomologists in an expanded form as Tineina, to indicate the whole series of minute moths of which the genus Tinea is only one little group. Many of these moths are much smaller even than the clothes moth, and they are found in all parts of the world and in all sorts and conditions of life-in relation to trees, shrubs, and plants of all kinds. It has been estimated that there are as many as 200,000 distinctly marked different kinds of these minute creatures. The insect collectors and students who occupy themselves with the magnificent butterflies and larger moths (of which there are an enormous variety of kinds) refuse to deal with the somewhat dull-looking and almost innumerable minute moths which are classed as Micro-lepidoptera, in contrast to the Macro-lepidoptera (or big moths and butterflies). Consequently they have become the favourite study of a few enthusiasts, who are known as Micro-lepidopterists, and have a wide but not uninteresting field of exploration all to themselves. The Micro-lepidoptera include, besides the Tineina, a group of less minute though small moths, with narrow, fringed wings, amongst which are the window moth, the milk moth, the tabby moth, the meal moth, and the grease moth. Though the clothes moths may well be described as "tiny" moths, yet the word Tinea, as applied to them, has no such origin, but is the 


\section{CLOTHES MO'THS}

name given to the destructive grub by the Romans. The same word has unfortunately been applied by medical men and botanists to a vegetable parasite which causes a skin disease (ringworm) resulting in baldness. The Tinea calvans of the doctors has only this in common with the moth Tinea pellionella - that it causes hair to disappear and baldness to ensue; but the vegetable parasite attacks the hair on a living man's head, the caterpillar that on his fur coat. 


\section{XXXVIII}

\section{STONE AND WOOD BORERS}

RORING into wood is a favourite proceeding on the B part of many small creatures, insects, shrimps, and ship-worms, by which they not only acquire nourishment, but at the same time penetrate more and more deeply into safe quarters and concealment. It is not surprising that it has become the necessary and regular mode of life of a host of small animals, and consequently that man who wants wood in good sound blocks and planks for his various constructions is a good deal put out by the voracity of the wood-boring community. To some extent he has given up the task of checking their proceedings, and now uses metal where he formerly used wood, but that only applies to a limited field. Wood is still the great material of rough construction, and the main substance used in fittings and furniture.

In our own country and in most parts of the world there are large grubs or caterpillars, such as those of the goat moth, three inches long and as thick as one's finger, which eat into the stems of trees and spoil the timber. The grub of the handsome moth known as the wood leopard is another of these. It attacks poplar trees, and we used to take it in numbers in the London parks and squares when I was a collector. The goat moth is specially destructive to willow trees. But there are a 
very large series of smaller grubs and adult insects which injure trees or bore or devour wood already cut and dried. Among these are the saw-flies and a number of beetles, and in Sicily and the tropics there are the wonderful white ants which are not ants at all, but more like May-flies. The destruction caused by these borers and eaters of wood is increased by the fact that when they have riddled a piece of wood, moisture penetrates it, and vegetable "moulds" flourish within it and complete the break-up. Among the most destructive borers of wood are those which attack the ships and piers of wood placed by man in the sea. These are certain shell-fish, called ship-worms (Teredo), which are really peculiarly modified mussels. There is also a tiny shrimp-like creature, the Limnoria terebrans, which does enormous damage by its borings to piers of wood erected in the sea. True insects do not flourish in the sea. There are marine bivalve shell-fish which bore into clay, sandstone, chalk, and even into hard granite-like rock. They do not use jaws or teeth for this purpose, but the surface of their shells, which are sharp and spiny, and also the sand which adheres to their soft muscular bodies like emery powder to the pewter-plate of a lapidary's wheel. You may see the large and small holes made by Pholas (called also "the piddock") and other bivalve shell-fish in the clay and chalk rocks of the seashore on most parts of the English coast.

Most boring animals swallow the material which they excavate in the act of boring, just as the earth-worm swallows the soil into which it bores, and as many sandworms do, throwing out from the hind end of the body, in the form of a little coiled-up heap, a vast quantity of undigested matter which has passed through them. But many insects which swallow some of the material disengaged by their jaws remove, in addition, a large quantity which is ejected from the boring as powder, like 
sawdust, and others do not swallow any of the material into which they bore. So, too, the Pholas and marineboring mussels do not swallow the material which they loosen. It is a very slow process, the boring in rock, and the fine particles rubbed away by incessant movement are carried off in the sea-water.

To some extent the marine creatures which bore in rocks seem to be helped by chemical action, since they show a preference for chalk and limestone, easily dissolved by weak acid secreted by the borer, though, clearly enough, they are not dependent on such chemical aid since we find them also boring in insoluble granite rock and shale and clay. There is one true worm-borer which perforates hard limestone pebbles and chalk rocks, so as to give them the appearance which we call "worm-eaten" when caused by another sort of worm and observed in a very different material, namely, old furniture and woodwork. At Tenby, in South Wales, the limestone pebbles on the beach are quite commonly riddled with these worm-holes, truly "worm-eaten." When they are not too abundant one can see that the holes are arranged in pairs like a figure 8 , about half the size here printed. On splitting the rock or stone one finds a deeply-running $\mathrm{U}$-shaped double tube excavated in the stone. In this the little worm lived. It is easiest to get at the worms in a fresh and living state on a coast where there are chalk-rocks and sea-washed lumps of chalk. The chalk is easy to split and cut at low tide, and then the little key-hole apertures can be broken across and the soft red worm extracted. It is a beautiful red-blooded little worm-little more than half an inch long-with two tactile horns on its head and little bristles and gills on the rings of its annulated body. It is a true "worm," like the earth-worm, what naturalists call by the not displeasing name an "annelid." It seems at first sight impossible 
that this delicate little thing should "worm-eat" the hardest limestone. It has no jaws, but one of the rings or segments of the front part of the body has two of its bristles swollen to relatively gigantic size, hard and black. These are its boring organs, but I have no doubt that it is helped, especially in its young state when commencing to bore, by an acid secretion from the surface of the body.

Curiously enough, in the strict sense of the word "worm," the boring of chalk and stones by the little marine creature just mentioned (whose name is Polydora) is the only instance of a "worm-eaten" condition being produced by a real worm. The worm-eaten condition of wood is produced either by the grub of a minute beetle (which is not in the strict sense a "worm") or by an ingenious human maker of "antiques" who imitates the little holes on the surface of the woodwork of old furniture, so as to pass off clever reproductions for really ancient cabinet work. The little holes to imitate those of the true insect furniture-borer are sometimes produced by discharging a gun loaded with fine shot at the piece of furniture which is to be passed off as ancient. But knowing purchasers probe the holes so made with a carpet needle, and discover the lead-shot sunk in the wood. Hence there has arisen a profession of specially-skilled "worm-eaters," who, by careful boring, imitate the holes made by insect grubs.

And now we come at last to the actual, real furniture worm or grub. It is the grub of a small beetle-the Anobium domesticum, scarcely one-fifth of an inch long (Fig. 62c), greyish-brown in colour, of a cylindrical shape, with the head completely concealed or overhung by the next division of the body, the thorax. The grubs are longer, soft, pale, and fleshy. The sign of the presence of the Anobium in your furniture is the existence of small circular holes here and there on the surface of the wood, 
with occasionally a little heap of yellow dust on the ground beneath them. This last sign is in fact the only proof you can have that the holes are not ancient and the burrows deserted, and that the enemy is still alive and at work. Rarely, if ever, can you see either the grub or the completed beetle into which it changes after forming a cocoon within the burrows, for they very seldom leave

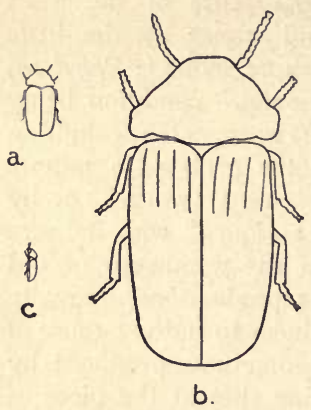

Fig. 62.- $a$, the death.watch beetle (Xestobium tessellatum) of the natural size (one-third of an inch long); $b$, the same beetle enlarged; $c$, the beetle (Anobium domesticum) whose grub is the furniture-worm, of the natural size, a side view. their excavations. But if you break up the wood you will find a surprising number of long, cylindrical passages, running side by side, and for many inches, through the deeper part of the wood, so that it may be quite rotten and ready to crumble, although presenting an uninjured surface save for the little round holes here and there. In these passages you will find both the grubs and the adult beetles.

A closely-allied and somewhatsmaller species of Anobium common in houses is of a more voracious character, not confining itself to dry wood, but eating bread, biscuits, rhubarb, ginger, and even cayenne pepper. This second kind, called Anobium paniceum, is the real "book-worm"; it gets into old libraries, and the grubs bore their cylindrical tunnels from cover to cover of the undisturbed volumes In a public library twenty-seven folio volumes standing side by side were perforated in a straight line by one individual Anobium grub or book-worm, and so regular was the tunnel thus eaten out that a string could be passed 
through the whole length of it, and the entire set of twenty-seven volumes lifted up at once by it.

There are one or two other grubs which less commonly injure books, and pass as "book-worms." But the most notable of the insect enemies of books and papers is a curious little wingless insect which never passes through a grub stage of existence, but hatches out in the complete form of his parents. He is about a third of an inch long, has the shape of an elongated kite, with a long tail and six legs, and is called by old writers "the silverfish," and by entomologists Lepisma (Fig. 63). This little pest does not burrow, but nibbles, and has destroyed many a valuable old document and ancient book. Paste and sugar are a great attraction to him, and he will destroy a boxful of printed labels or a valuable manuscript, leaving only the ink-marked parts untouched, but ready to crumble.

Closely allied to the book-worm beetle, Anobium, is a larger beetle, called Xestobium tessellatum (Fig. 62a) which infests old woodwork, its grubs making correspondingly larger tunnels. The entire woodwork of a house has had to be removed and replaced in consequence of this creature's depredation, and such pieces of furniture as a four-post bedstead have been riddled and made rotten in two or three years by its burrowing. It is still common in England in old wood-panelled rooms and in wooden mantelpieces. The most interesting fact about it is that it is the maker of those nocturnal tappings which are known as the "death-watch." It is the beetle itself (Fig. $62 a$ ), not the grub, which makes these sounds. It makes them by deliberately striking the wood on which it stands, with its head. The taps are usually from five to seven in quick succession, the sound dying away in intensity in the later strokes. A second, and even a third, beetle will then reply with similar taps from the woodwork 
of some other part of the room. Years ago I used to be gently lulled to sleep by these "raps" in my rooms at Oxford, accompanied by the sound of spasmodic rushes of mice behind the woodwork. At first I thought the tapping was caused by the falling of drops of water through a leaky roof, but soon ascertained the actual cause. One does not notice these tappings until the dead of night when all else is still, and they are so mysterious and persistent that one can understand superstition arising in connection with them, and that the nerves of any one already overwrought, might be so affected by them as to lead to the belief that evil spirits are "rapping," or that a ghostly coffin is being nailed together for a dying man. The little beetle has often been tracked by a naturalist, and discovered in some concealed position nodding its diminutive but hard head with sharp jerks, and producing an almost incredible volume of sound in proportion to its size. If the beetle, when discovered, is kept in captivity in a wooden box, it is easy to set it " tapping " or "rapping" by tapping oneself with a pencil on the table on which the box is placed, when the faithful little death-watch will unfailingly reply. Possibly some of the "raps" recorded by the pioneers of spirit-rapping, when not produced by the toes of designing mediums like the young ladies of Rochester, N.Y., were actually made by death-watch beetles. It is certain that the somewhat eccentric supposition that disembodied spirits endeavour to make signals to living humanity by "rapping" owes its origin (long before the nineteenth-century craze for "spiritrapping ") to the measured tap-tap-tapping of the deathwatch beetle, and the consequent superstition at a time when the beetle was not known to be the "tapper."

Whilst the bigger beetle, Xestobium, is the common death-watch, it has been proved that the little furniture beetle, Anobium, is also a tapper, making regular and 
persistent strokes like the ticking of a watch. Another insect, called the book-louse (Atropos divinatoria), very minute, only one-twentieth of an inch, soft, white, and wingless, not a beetle at all, but also a devourer of literature (Fig. 64), is declared by some good observers to be a "ticker" or "tapper," but other naturalists deny that it can make such sounds. It seems unlikely on account of the extremely small size and softness of the book-louse, but the matter needs further investigation.

A curious fact is that the grubs of beetles such as Anobium and Xestobium (or other closely allied kinds) are not arrested in their tunnelling by soft metal. They cannot tackle iron plate or brass sheeting, but they will penetrate tinfoil and, what is more astonishing, lead plate and leaden waterpipes. Specimens

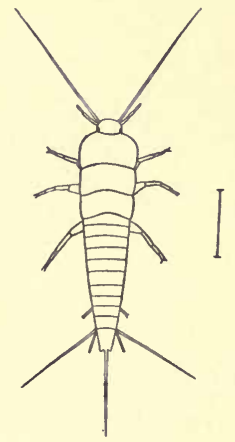
showing such perforations are in Fig. 63.-The silver-fish insect the museums of Oxford and London, and I have received an account of a lead pipe packed in (Lepisma saccharina). The line to the right shows its natural size.

wood in the wall of a house being perforated by these beetle-grubs. Once at work on the wood, "the straightforward intentions" of the grub are not to be diverted by such an obstacle as lead: it goes straight on through the lead as it would through the cover of a book or a knot in the wood.

I have sometimes been asked to give advice as to the best method of destroying the furniture worm or grub. If the piece of furniture (or its pieces) can without injury be "baked" in a hot chamber for twenty-four hours, at a 
temperature a little above that of boiling water, that is the easiest method of destroying the pest. Or, again, I should suggest placing the piece of furniture in a refrigerating chamber for a week or two. If neither of these methods can be used, the piece of furniture should be placed in a very hot room, and creosote or bisulphide of carbon or solution of cyanide of potassium should be injected with

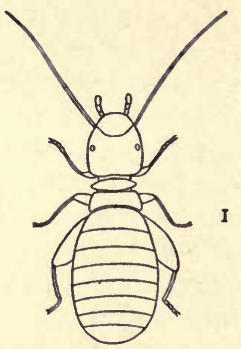

Fig. 64.-The book-louse, or Atropos divinatoria, a soft, cream-coloured, wingless insect smaller than a flea. It is believed by some observers to be capable of making sounds like the ticking of a watch.

a very fine-nosed syringe into the little circular holes of the burrows on the surface of the wood; then the piece of furniture must be at once exposed to the cold, which will cause the air to be drawn into the burrows and diffuse the volatile poison within. The "worm holes" on the surface should, as soon as the piece of furniture is quite cold, be closed by melted paraffin. If the piece of wood which it is desired to "cure" will stand submersion in water for a few minutes, and is not larger than a cricket bat, it is, of course, easy, by first warming it through and then plunging it into water containing corrosive sublimate or other poison, fairly to impregnate the burrows, and make an end of the beetles and their grubs. Painting is the common and approved means of protecting wood against these attacks, and in some positions metal sheathing is used. The method most largely used for protecting wood in the open air against "worm" and "mould" is that of forcing creosote into its pores-an improvement on the old system of painting with coal tar. A more expensive but beautiful method 


\section{STONE AND WOOD BORERS}

of protecting wood is to force hard paraffin in a melted condition by pressure into the pores. The wood becomes wonderfully firm and waterproof. Neither damp and mould, nor boring insect, nor shrimp can then penetrate it. This method was introduced some years ago, but I do not know whether it has been largely used. 


\section{XXXIX}

\section{CHRISTMAS FARE}

W OST English people who can afford it eat more consider it more or less of a religious duty to do so, even though they shrink from the ordeal. It is an interesting tendency, and at the same time one readily explained. Primitive men, and our own remote ancestors, had few, if any, joys greater than those afforded by an abundant meal of roasted meat. When a great beast such as a mammoth was taken in a skilfully-prepared pitfall, and slaughtered, the whole tribe of palæolithic huntsmen assembled and gorged themselves with its flesh, which, it seems fairly certain, they cooked on open fires. The strongest seized the most and ate the most, and were able to bear up the longest in something like full vigour until such time as another big beast should be killed, and another opportunity for "gorging" should arise, when they would naturally again get the largest share, having eaten most on the previous occasion, and so being least famished. Hence the belief that a great appetite is a fine thing, and that the more you can eat, the stronger and better you are, is one of the deeply-laid traditions of humanity which civilised men have inherited from barbarians, and are only slowly commencing to criticise and to put aside. The negroes who accompany 
European sportsmen in Central Africa gorge themselves when elephants are killed, and a recent account tells of the serious illness and danger to an expedition caused by the whole countryside flocking to the carcasses of twenty-three elephants killed by an ivory-hunter. The blacks continued to eat the flesh of the elephants for three weeks, when it had become decidedly "high," and many died, whilst others took weeks to recover, in consequence. The notion of "festivity," which, especially in England, has been, even in recent times, that of eating and drinking to excess, is prehistoric and barbaric. Serious physiologists and medical men have expressed the opinion that we shall never arrive at a satisfactory mode of nourishing ourselves so as to take neither too much nor what is in itself injurious to health, until the practice of seeking gaiety and celebrating a memory or honouring a friend or friends by means of profuse eating (often followed by wearisome speeches) has given place to a mode of rejoicing which is more likely to produce hilarity and lightness of heart, and less certain to be followed by painful and injurious results. We certainly eat less and drink less of intoxicating liquors than we did, but there is, it seems, still room for improvement.

To connect heavy feeding with Christmas, the third in rank of the great festivals of the Church, is not a universal custom, and is, in fact, a peculiarity of our own country, arising from the rearing and management of cattle in early times, when English pasture land furnished a splendid means of enriching its owners by the production of "hides" and leather. Large numbers of cattle had to be stalled during winter and fed on stored herbage, and a great many were at this season killed and the meat "salted down," since it would not pay to keep them on stored food. It was not until the introduction of "root-crops" that oxen could be kept in 
any number through the winter months. Hence there was an excess of fresh meat and fat about Christmas time, and the "roast beef," plum puddings, and mincemeat of Christmas fare were abundant. The true Christmas pudding and mince-pie had meat as part of their components, and, of course, beef-suet enters largely into their composition at the present day.

The practice of eating sweet fruits and preserves with meat (as in the true mince-pie) still lingers in this country, but has become less general than it is in Germany. We still eat red-currant jelly with roast mutton, and also with hare, and apple sauce is considered appropriate to roast pork and to goose; but pickled plums and cherries and sugared crab-apples, which are usually taken with meat in Germany, are not known to us. I have heard a schoolboy express indignation at being given plums with roast meat. Mincemeat, for mince-pies, was originally (like a "Cornish pasty," in which raisins are mixed with meat) one of these combinations of sweetness and strength-of sugar and meat-the taste for which has unaccountably disappeared in these days of mechanical uniformity and lack of " homely cheer."

The introduction of the turkey as a Christmas dish dates from the early time of the importation of that bird into Europe, namely, about I 550. It is already spoken of in connection with Christmas fare in 1570. The "turkey-cock," as its full name was, is an American bird, and was brought originally from Mexico to Europe, though it is possible that the more northern American species may have been also introduced by the navigator, Jean Cabot. There is a very gorgeous turkey-cock of iridescent bright blue and green, with orange-red warts on his head and neck, found in Honduras. But he has never been acclimatised. $\mathrm{He}$ is on view in the Natural History Museum. The turkey belongs to the pheasant 
family, and is compared by old writers to the peacock, and also to the guinea-fowl (Numida meleagris of ornithologists). Indeed, there was great confusion when the turkey first arrived between it and the guinea-fowl, and it appears to be owing to this mixing up of the two birds that the American bird was called a turkey-cock, since the guinea-fowl is an African bird, and came into the hands of Europeans through Mussulman traders or "Turks." So far did the confusion go that the great Linnæus applied the Latin name Meleagris, which was that of the guinea-fowl, to the "turkey" of America! Some people think that the turkey-cock established his misleading name by his cry, which they say is represented by the words "Turk-turk-turk." Probably the turkeycock, though an American bird, was imported by traders who were called "Turkey merchants" because their chief business was with the Levantine and Morocco ports. Another mistake or vagueness as to the native home of the turkey was hit upon by the French, who called it the Poule d'Inde, whence their modern name for it, Dindon; and the same error is found in an old German name for it, Kalkuttisch Hiin (from Calicut, on the Malabar coast of India, where the turkey was introduced from America in the seventeenth century, and has flourished ever since). The Swedish name for the turkey is Kalcon, and is only a modification of this old German name. Probably few animals or birds have been so persistently misrepresented by the names given to them as the American bird which we call the turkey.

Our farmyard names for him are far better. In Scotland they call him the "Bubbly-jock," which vividly suggests his airs and graces, whilst in Suffolk we call him a "Gobble-cock." I know an old farmhouse near Woodbridge, in Suffolk, which bears the delightful name of "Gobblecock Hall." "The squire of Gobblecock 
Hall" would have furnished Randolph Caldecott with inspiration for a Christmas picture story; and so, indeed, would the country round the "Hall," with its vast sandy tract, ten miles long, known as Hollesley Heath, ending on the seashore near Orford Castle.

The misleading indication as to the native land of an animal-due to the name commonly applied to it-is remarkable in the case of the guinea-pig. Though the guinea-fowl is correctly so called, since it comes from the Guinea Coast of Africa, the guinea-pig has nothing to do with that coast, but comes from South America! It is not a pig, but a rodent, and it does not come from Guinea. It appears that the ships of the "Guinea merchants" of this country established trading relations with South American ports, and hence the little "pig" (Shakespeare calls the hedgehog "hedge-pig") which they brought home was called a "guinea-pig," just as the big "cock" imported by Turkey merchants was called a "Turkey-cock." The guinea-pig suffers other "indignities of appellation." The Germans call him Meerschweinchen, that is, "little sea-pig." Apparently "sea" pig, because he was brought over the sea. But this leads to unjustifiable suggestions as to the guineapig's character. For the Germans call the porpoise Meerschwein, which would seem to mean "pig of the sea "; and those imperfectly acquainted with the German language have been known to take allusions made by German writers to the former animal as intended to apply to the young of the latter. Thus one reads in an English medical book of a number of "young porpoises" being fed upon carrots when it was really "guinea-pigs" which consumed this nutriment. The German physiologists, who often make use of guinea-pigs in their investigations, now call them Cobayas, so as to avoid any further misunderstanding. The French word for a 
porpoise, marsouin, is a corruption of the German name Meerschwein.

I have pointed out above the origin of heavy feeding at Christmas. Whether it is necessary or not to continue that precise mode of celebration, the sentiments of peace and goodwill which belong to Christmas, the meeting of kinsmen,-and, above all, the dedication of many of its customs to children,-are things to be cherished and treated tenderly. The $25^{\text {th }}$ day of December was fixed by the Church for the celebration of the birth of Christ, but it is fairly certain that the period of the year indicated in the Gospel as that when the shepherds were watching their flocks and saw the star of Bethlehem, was not December, but October. It is also certain that the children owe their share in Christmas to the combination with it of customs proper to the Epiphany, which celebrates the bringing of gifts to the child Christ by the wise men of the East. It appears that the greatest and gayest of the feasts of pagan Rome-the "Saturnalia" - was held at the end of December, and that the early Church in this, as in many other cases, adapted a pagan custom to its own uses, and fixed the feast of the Nativity at this date expressly in order to take over, as it were, the gaiety of the Saturnalia. The brilliant foliage and berries of the holly-tree were used for decorations at the Saturnalia, and thus became a Christmas emblem. The fun and frolic of the Saturnalia were transferred to the name of Christmas, and thus it comes about that the Yule Log and the Lord of Misrule and the Abbot of Unreason, and also snapdragon and clown, harlequin and columbine, are found in full swing at Christmas-tide. Later St. Nicholas, who took the place of Neptune, and was the patron saint of sailors, became associated with Christmas celebrations as Santa Claus or Father Christmas. His regular day was at the beginning 
of December, and so it was easy to postpone his festivities to three weeks later.

Mistletoe is not a Christmas decoration. It comes to us from the Druids, and belongs to the New Year. It is not allowed to appear in church, and should not be hung up in private houses till Christmas is over and the New Year has come. The hanging up of the mistletoe is in itself a beautiful survival of an ancient worship, and should be associated in our minds with Stonehenge and the prehistoric star temples, whose priests were astronomers. On New Year's Day they solemnly distributed branches of the mistletoe to the people as a charm ensuring fertility. In December there are many hundredweight of mistletoe cut down and despatched from the ancient Druidical haunts of the Welsh border, and from over-sea Brittany, to all-devouring London, where it is heedlessly nailed up in doorways, and made the excuse for much giggling and embracing. May those who read these lines treat it with due reverence, and when they kiss beneath the beautiful strange branch with its white berries, think of our ancestors-the noble youths and lovely maidens of prehistoric days, who kissed three thousand years ago, and sent this living token of their happy lives down the long ages - to us, distracted hustlers of the motor-car. Prehistoric feeding may not be good for us, but the prehistoric rite of the mistletoe must not be neglected in these days of strange political aspirations on the part of those who have not discovered its sedative virtue. 


\section{XL}

\section{THE ORIGIN OF OPIUM}

THAT Europe is the original home of the opium1 poppy, and not Asia, is even more contradictory of our settled traditions and belief than the fact that Europeans gave tobacco to the East. Yet it is the fact that opium, like tobacco, came to the Far East from Europe. The opium-poppy does not grow wild in Asia; it is a cultivated variety of a Mediterranean poppy, the Papaver setigerum, which has a pale purple flower, and was conveyed, long ago, by man from the Levant to Asia. We have true poppies of four species which grow wild in England, all with splendid scarlet or crimson petals, easily distinguished from one another by the shape of the seedboxes, or capsules, which they form. If you scratch the surface of the seed capsule of one of these poppies a milky juice appears. It is this which is collected from the capsules of the much larger opium-poppy in India and China, and when dried forms a hard brown cake, which is called "opium." It consists of resinous matter, in which is contained a small quantity of the invaluable narcotic called "morphia," and also small quantities of other powerful poisons.

The pale-purple poppy of the Mediterranean (Papaver setigerum) was cultivated hundreds - even thousands-of years ago in the South of Europe and $3_{3}$ 
on the Mediterranean shores of Africa-not for opium, but for the oil which can be expressed from the seed, "poppy-seed oil." The oil is free from narcotic properties. The purple poppy is still cultivated for that oil in France, and poppy-seed oil is an article of commerce used as food, both in the pure state and for adulterating other oils. The earliest cultivation of this poppy is even as remote in Europe as 7000 years, for we find that the Swiss lake-dwellers of the Stone Age cultivated it, and that the variety they obtained was nearer to the wild Papaver setigerum than to its cultivated derivative, the modern opium-poppy, Papaver somniferum. How and when it first was recognised that the narcotic substance "opium" could be prepared from the juice exuding from the cut capsule is not exactly known, but it is probable that it was not until the early Middle Ages that the poppy was cultivated for the habitual use of opium as a narcotic indulgence, and that its earlier cultivation was, as to some extent at the present day, for the sake of the oil contained in the seed, its use in medicine requiring but a very small supply. The ancient Greeks were well acquainted with the cultivated poppy. Homer mentions it, and at a much later period Theophrastus and Dioscorides do so. They call it "mekon," and were aware of the somniferous properties of the sap. Dioscorides, whose wonderful book on plants dates from the first century of our era, speaks of the drug derived from the sap by the name "opos," and it is from that word that the name "opium" has come. The Romans cultivated the poppy before the republic, and mixed its seeds with their flour in making bread. The story of King Tarquin taking the governor of a rebellious province into a poppy-field, lopping off the heads of the taller poppies with his stick, and then turning to his visitor, without a word, but with a look 
which said, "That is the way to govern"-is evidence of the very early cultivation of the poppy by the Romans. Hebrew writings do not mention the opium poppy, though it seems to be certain that it has been cultivated in Asia Minor for at least 3000 years. There is no evidence that the plant was cultivated in more ancient times in Egypt, although in Pliny's time the Egyptians used the juice of the poppy medicinally. In the Middle Ages it was, and in our own day it is, one of the chief objects of cultivation in that country, especially for the manufacture of opium.

The cultivated variety $P$. somniferum of the present day differs from the wild $P$. setigerum, in having the seed-capsule surmounted by ten or twelve stigmas (the free ends of the leaves which are united to form the capsule), instead of by eight as in the wild form. It seems that the introduction of the poppy from the shores of the Mediterranean into Persia, India, and China is due to Arab traders, and is coincident with the rise of Mohammedanism; and it is probable that it was valued and cultivated from that time onwards, not so much for the sake of its seed and oil, as for the narcotic juice, which was made up by Arabian "confectioners" into a kind of paste, and eaten, as were other vegetable extracts-such as "bang," from hemp-for the sake of the pleasurable effects produced by its poisonous action on the nervous system. It is certain that the opium poppy does not occur at all in the wild state in the Middle and Far East. In I 5 I 6 opium was already an article of trade from India to China. The poppy was cultivated, and the use of opium known and frequent in India for some five centuries before that date. Probably the cultivation of the plant in China was not started until the eighteenth century.

It was the Chinese who hit upon the mode of in- 
dulging in opium by smoking it in a pipe. There is no record, written or pictorial, of this practice earlier than I 730 , about fifty years before which date (I680) we find the smoking of tobacco represented on Chinese pottery. Very soon the Chinese were not content to import their opium from India, but large areas were put under cultivation with the Indian poppy in China and Manchuria. For a century or more the export of opium from India to China continued and increased as the consumption of the drug increased, the native Chinese production not being sufficient to meet the demand. In 1730 and 1796 the Chinese Government issued edicts forbidding the smoking of opium, and in the last century the efforts of the Chinese authorities to prevent the importation of Indian opium, whether with a view to suppress a dangerous vice or to favour the home-grown article, led to war with England. In some parts of China-for instance, Amoy - three-fourths of the population are, or were until lately, opium-smokers. Now it is believed that the Chinese Government is genuinely determined to put a stop to the dangerous and enervating indulgence in this narcotic, and the opium-growers of India will have to limit their output, and employ their land and labour for other crops.

It is the fact that the eating of opium (for it is not "smoked" there) does very little harm in India, since it is not used by a large proportion of the people nor in excess. Many persons who have studied the subject maintain that the widely-spread injury caused by opium in China is due to the short time during which it has been in use there as compared with India. It is held that a population after a few centuries becomes immune to such poisonous but attractive indulgences by the killing out of those who cannot resist excess-and the suggestion is that the simplest way of dealing with such cravings for poison is to let those who have them and 
cannot resist their demand, freely indulge and die, and their stock with them. This is, however, a slow and tedious way of eradicating an evil tendency. It may, perhaps, be the only way, and hereafter, when the production by careful and restricted breeding of a sound and healthy population becomes recognised as being part of the duty of the makers and administrators of the law in civilised states, it is not improbable that we shall see something of the kind deliberately put into practice.

The opium-pipe and the mode of smoking at present in use in China are very different from the pipe and smoking of tobacco used there or elsewhere. I investigated the matter myself twenty years ago in an opiumden near the London Docks, under the instruction of a polite Chinaman. The opium-pipe has a very narrow cavity, about one-sixth of an inch wide. The prepared opium, in a condition resembling treacle, is smeared on the walls of the cavity with a pin, and the pipe is held to a lighted lamp. The flame drawn into the pipe causes the opium to frizzle and give off smoke, but it does not "light" and continue to burn. Each whiff which the smoker inhales has to be procured by applying the pipe to the lamp. The smoke is tasteless, and it requires a good deal of patience and several re-smearings of the inside of the pipe before the smoker begins to experience the pleasant effects of the drug. These consist in the production of a sense of perfect contentment and indifference to all trouble and care, whilst the imagination gives a rose-colour, or an even more alluring aspect, to all that one sees or thinks of-until a gentle sleep closes the scene.

The Chinese, having obtained the seeds, cultivated the opium-poppy, and made opium before the prepared article was imported in any great quantity from India. There is, of course, no doubt as to the injury which is 
done to a population by the habitual use of opium. At the same time, there is no one who knows anything about medicine and the use of drugs who does not speak of opium with reverence and even affection. Forty years ago, at a dinner-party where the leading physicians of London were present, it was suggested that they should each write down in order of merit the ten drugs to which they attached the greatest value. I heard from one who was present that they all put opium in the first place, and that mercury, iodide of potassium, and ipecacuanha followed in that order in the majority of the lists. The value of opium as a medicinal agent is one thing; its deadly effect on those who have become victims to its daily use is another. The origin of the medicinal use of opium can be traced to Egypt in Pliny's time, but beyond that nothing is known.

As I am writing of botanical matters, I may briefly refer to an ambiguity about the names "banana" and "plantain." There is no difference (as is sometimes suggested) between the fruits indicated by these two words. Our word "plantain" is merely a corruption of the Spanish word platano, which is the name of the plane-tree. It was loosely applied in South America by the Spanish colonists to the banana palm (Musa sapientum), just as they called the North American bison a buffalo, and as the Anglo-Americans call a stag an elk, and a red thrush a robin. The banana palm is not an American tree, but was introduced there from the East Indies by the early navigators, and was very soon cultivated by the South American Indians as well as by the colonists. There have been great authorities-for instance, Humboldt - who have believed that there is a native South American banana palm as well as an East Indian one; but the definite conclusion of botanists, after careful inquiry, is that there is only one species, and that 


\section{THE ORIGIN OF OPIUM}

it is of South Asian origin. There are an enormous number of cultivated varieties-forty-four are described; they can all be arranged in two groups, the large-fruited bananas (fruit 7 inches to 15 inches long), and the smallfruited bananas, commonly called fig-bananas (fruits I inch to 6 inches long). All are equally entitled to the name "plantain" as well as "banana." The finest flavoured varieties are cultivated in Hindustan, and there only, being often of very great value and rarity. Those which come into the English market are chiefly, if not entirely, of West Indian production. The foliage of the banana palm consists of oblong leaves of magnificent size and unbroken surface; small trees are to be seen in hothouses (they bear fruit at Kew), and are frequently used for decorative purposes. 

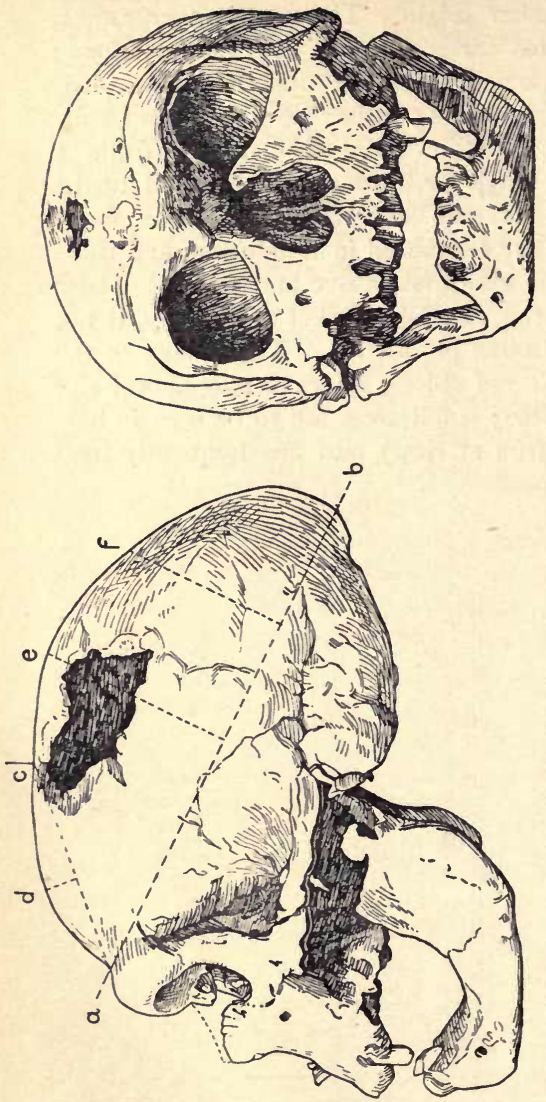

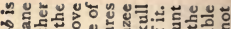

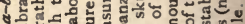
E

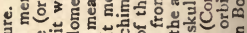

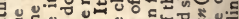
क्ष ธ० क. 与 हू으.

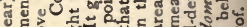

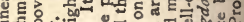
등용 ज्ञ二ं क. क สंग प v 들

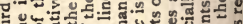
‡5 50 ปั

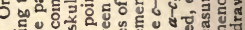

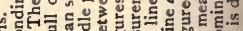

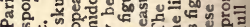

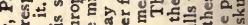

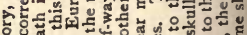

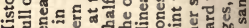

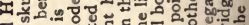

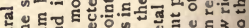

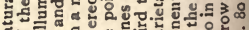
舟

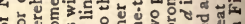

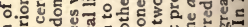
E

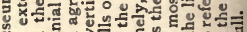

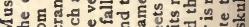

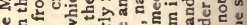
둥

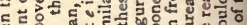
3.

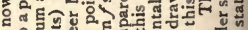
n

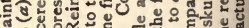
ทึ जั xं

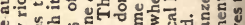

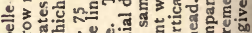

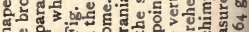
牙论 을

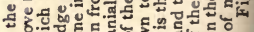

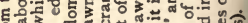
연. 은

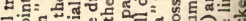
సं을 ๙

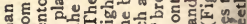

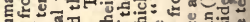
g

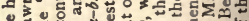
준돈

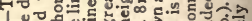
. ن. 


\section{XII}

\section{THE MOST ANCIENT MEN}

I $\mathrm{N}$ the winter of $1908-09$ a very interesting discovery was announced in the daily newspapers-the discovery of a human skull and some bones buried in a cave called the Grotto of the Chapelle-aux-Saints, in the central department of France, known as the Corrèze, not very far from Perigueux, in the Dordogne. An account was given of this discovery by Professor Marcelin Boule, of the Paris Museum, to the Académie des Sciences, and the description of the bones, which had been carefully pieced together, and were exhibited to the meeting of the Academy, was sent by him to me (see Fig. 65). Some exaggerated statements as to the monkey-like character of the race to which these bones belonged (exaggerated, but not altogether devoid of truth) were circulated by imaginative correspondents in the newspapers. It is the fact that these human remains are of enormous antiquity, and belong to a very peculiar and primitive race known as the Neander Men, so called because a skull and some bones of this same race were found fifty years ago in a cave in the Neander valley, ${ }^{1}$ near Elberfeld, on the Rhine.

The French archæologists, or "prehistorians," as we

${ }^{1}$ So named after one Neumann, a religious enthusiast, who inhabited the cave. 
now call them-are the leading discoverers in all that relates to very early man. The caves in Central and Southern France (Dordogne, Pyrenees, and Riviera) and the gravels in the north have furnished the most wonderful and interesting evidences of the existence of human beings at an immensely remote period in this part of Europe. Enthusiastic excavators and collectors of French nationality have discovered, preserved, and described the weapons, carvings, and drawings made by the old cave-dwellers of Southern France, buried by the accumulated deposits of ages deep in the caverns where the human artists who made these things used to live. In England only two such caves containing the implements of prehistoric men have been found-whilst a few are known in Belgium, Moravia, and Switzerland.

Although we know an immense number of the flint instruments, bone harpoons, and carvings and drawings of the ancient cave-dwellers, yet skulls and bones of the men themselves are extremely rare. Bones, skulls, and teeth of the animals they killed and ate are abundant in the caves-such as those of great bulls, deer, and horses. The bones also of animals which lived in these caves and contended with the ancient men for the possession of the shelter afforded by them, are abundant: bones of hyæna, of bear, of lion, and wolf. But human bones are exceedingly rare. This arises partly from the fact that human bones are not so thick and strong as those of large animals, and more easily soften, break up, and are lost. It is also due partly to the fact that the men were not nearly so numerous as the wild animals; but it is chiefly due to the fact that these people usually, but not always, buried their dead in the open; and whilst the bones of animals which had been eaten were left about in heaps on the floor of the caves, and became cemented together by the petrifying 
deposit caused by water dripping from the walls of these limestone caverns or by streams actually flooding the caverns, the bodies of the men themselves were removed when they died by their friends and families, and buried in the open ground, where they have gradually dissolved and broken up. Only a few here and there of the more ancient races were buried in a cave, and are in consequence preserved until the present day. Obviously, it would only be an exceptional honour or superstition which would cause the giving up of a cave to the interment of a dead body, or only rarely that a corpse could be tolerated in the floor of the cave still inhabited by living men.

It is a mistake to suppose that all the bones of all the men and animals which have lived on the earth's surface are naturally and as a matter of course permanent enduring things. On the contrary, when they are buried in soil or sand permeated by water, they slowly soften and decay, dissolve and disappear. When washed into streams and rivers or into the sea, they break up and dissolve. No bones were dredged up from the floor of the ocean by the explorers of the Challenger expedition. A bone sunk in the sea gradually dissolves. Only those bones (and the same is true of shells) are permanently preserved which happen to get into certain favourable positions, embedded in clay or hard deposit, which is not disturbed, and becomes slowly raised up and free from soaking water before the bone is dissolved; or, again, those which have been protected in the accumulated deposits of the floor of a cavern covered in by layers of hard calcareous slab or stalagmite, which usually is formed by the water dripping from the limestone roof and walls. The limestone is dissolved like sugar, and is deposited when the water evaporates"petrifying" the floor of the cave. It is owing to this 


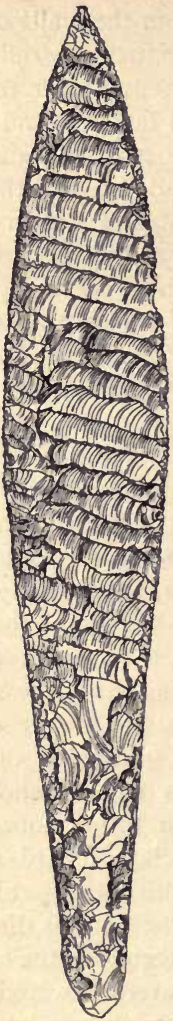

FIG. 66.-An unpolished but beautifully chipped flint knife, of the Neolithic Age, from Denmark. (This figure and Fig. 67 are from the guide to the antiquities of the Stonc Igc in the British Museum). rarity of the natural preservation of bones that we never find more than a few of those of extinct animals of various degrees of antiquity, and never more than a very few of those of the ancient men who lived in caverns and made "flint implements."

As a preliminary to dealing below with the story of "the Neander Men"- to which race the newly-found skull and bones from the Corrèze belong-it will help to make the importance of that skeleton obvious if I very briefly and dogmatically state what are the great periods in the prehistoric record of man, and the probable distance in time from us of those periods. It must be remembered that what I have to say applies only to the "prehistoric history" of man in Western Europe and the Mediterranean region, for it is only this part of the world which has been sufficiently carefully examined to yield any definite conclusions. Let us suppose that we can 
travel back through the ages, and proceed to do so. We find that there are three well-marked successive periods in Europe-which are called the Iron Age, the Bronze Age, and the Stone Age. When we go back to Julius Cæsar conquering Gaul and parts of Germany and Britain, we find that the Romans had steel swords, and freely made use of that metal for a variety of tools and constructive purposes. The Gauls and Belgi and Allemanni and Britons were still in the Bronze Age; they had beautifully made bronze swords and daggers and helmets and shields, which were weaker and softer than those of iron used by the Romans. The use of iron was soon spread by the conquerors, and the rest of Europe entered on the Iron Age. When the Anglo-Saxons arrived in England they had iron weapons. At what date precisely the Romans themselves took to the use of iron is not known, probably they learnt its use from the peoples of Africa; but at no distant date,

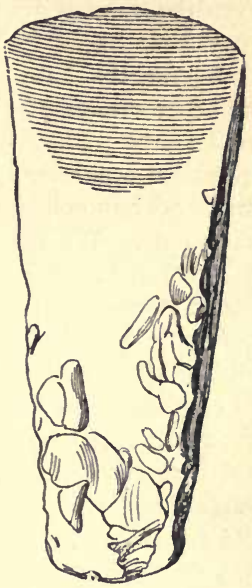

FIG. 67.-A polished flint axehead, of Neolithic Age, from Denmark.

a few hundred years before Christ, they, too, and the Greeks were in the Bronze Age. In Western Europe we see the Bronze Age, as we travel back in time, disappearing, and we come to the Stone Age, about 2000 B.C. Copper was used at the later stage of the Stone Age, and then the alloy with tin, which is called "bronze." At the time that the big stones of Stonehenge were set up (the smaller stones of the outer circle 
are more ancient) the Stone Age was coming to its end, and the Bronze Age coming in.

Everywhere, but not always within the same thousand years or so, we see as we go still farther back, the use of metal giving place to the use of stone. In Europe we see a highly-developed material civilisation from three to seven thousand years ago. The people till the land, sow crops, keep herds, build houses (of wood), make pottery combs for the hair, necklaces of amber and of shells, and other ornaments, but they have no metal weapons or implements. They sometimes use native gold to make decorative ornaments ; but their knives, daggers, swords, saws, and hammers are all of stone, either flint or dense greenstone. We reach this purely Stone Age in Europe at 2000 B.C. ; in Egypt we do not get back to it so soon, but, about 5000 B.C., we there come upon a prePharaonic population which made use of beautifullyfinished stone knives in place of metal. The first people we come upon in Europe as we pass from the Bronze to the Stone Age had a great deal of skill and an elaborate social organisation. Their stone weapons were beautifully chipped and often highly polished (Figs. 66 and 67). We find the slabs of grit upon which they rubbed the chipped flint adzes in order to make them smooth. But soon we find, as we go back, that polishing is unknown, and that the chipped flint adzes are used in a rough state. On entering the Stone Age we find that we are only on the fringe of an immense period of "stoneweaponed humanity," extending back for tens of thousands of generations of men, when stone (and in Europe especially, that stone which we call "flint") was the one great stand-by of the human race-the one hard cutting material which man learnt to shape and apply to his own purposes_-so as to make holes with it, saw with it, scrape with it, cut with it, kill with it. On 
account of its prodigious range in time it is found necessary to divide the Stone Age into two periods-a later, called the "Neolithic" (the new stone period), and an older, stretching back until the traces of it are lost in geologic changes of the earth, which is called the "Palæolithic" (the old stone period).

Thus if we start on a time-journey to explore the earliest traces of man in Europe, we pass along the centuries back, through the Iron and the Bronze Ages of humanity, and arrive at the vast Stone Age, which stretches away into the obscurity of more than a hundred thousand, probably of many hundred thousand, years. The later or newer fringe of the Stone Age is called the "Neolithic," or newer Stone Age, or Age of Polished Stone, because the men of that period polished their stone implements after chipping them into shape. That which we dimly see beyond is the "Palæolithic," or older period of "stoneweaponed" humanity, when polishing was unknown.

The Neolithic civilisation comprised the Swiss and Glastonbury lake-dwellers, who built houses on piles in the water: also the makers of the kitchen-middens of Denmark, and the builders of the great stone avenues, circles, and cromlechs, and the elevators of the solitary big stones called "menhirs"-most of them rougher and probably two thousand or three thousand years older than the big stones of Stonehenge. Our journey has now brought us into the full darkness of prehistoric times. We cannot tell how far back this "Neolithic" period reaches, but there are things found which make it certain that it reaches to 7000 B.C., and probably a good deal farther. We are now far in time behind the most ancient Greeks and the more ancient Egyptians. Europe is a rich, moist pastureland, peat bogs are abundant and luxuriant woodlands; the climate is mild; the wild animals are those which to-day inhabit Central Europe, but more abundant. The 
domesticated animals kept by the men are those which we have to-day, and many of the crops and cultivated plants are those of our own time, such as wheat, barley, oats, and rye. We know also by their remains that the Neolithic men fed on chestnuts, hazel nuts, walnuts, plums, apples, pears, and strawberries, and cultivated the vine, the pale opium-poppy, and the narrow-leaved flax. Hemp was not known to them.

- As we push back still farther into the night of antiquity - we cannot say at how many thousand years from to-day, whether ten, twenty, or fifty thousandthe climate becomes very cold, the glaciers extend far down the valleys, and we note that the level of sea and land has changed. Great Britain and Ireland are part of the Continent of Europe. There are strange animals in the south of what was England, and there, as well as in France, reindeer abound, wild horses, the bison, the Siberian saiga antelope, the great ox, bears, gluttons, and wolves; and there are men living in caves-the natural caverns which form in limestone rock. These men are chipping flints (but do not polish them) and carving bones, but now have no herds, nor cultivated fields, nor pottery (some very rough fragments have been found), nor buildings, nor earthworks. They are like some modern savages, Nature's gentlemen, "who toil not, neither do they spin," but they hunt and fish. They live entirely on the produce of the chase and on fish, wild fruits, and roots.

They wear undressed skins and furs, and paint or tattoo their faces. They make twisted ropes (probably of skin) which they fix as a halter round the head and jaw of the wild horse, as shown by their own carvings (Figs. 8 and 9). Probably they ride him. They certainly eat him. At Solutré, near Mâcon, the bones of no less than a hundred thousand horses were found piled up as 
a sort of kitchen-midden round a camp of Palæolithic men! They have the art of making fire, and have a wonderful artistic skill in carving and drawing on bone and ivory and on stones, and in painting on the walls of their caves, the animals which surround them and are hunted by them (Fig. 7I). They make great numbers of carved harpoons or toothed spearheads (Fig. 68) from bone, and also needles for sewing skins; whilst from flint they chip spear-heads, knives, handhatchets, and saws. They decorate their carvings with spirals, lozenges, and circles cut in low relief (Fig. 69). But their truly astonishing skill and mental development is shown in their carvings and engravings of animals and fish (Fig. 70), which are executed either on bones or stones, or on pieces of the ivory of the mammoth. Besides the reindeer, horses, goats, saiga antelope, rhinoceros, mammoth, and seal, their carvings include statuettes and drawings of men and women (Fig. 7).

At the best period some

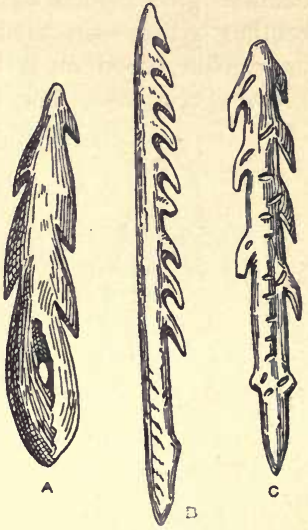

Fig, 68.-A. Perforated harpoon of the transition period (Azilian or Red Deer period), between Palæolithic and Neolithic, made from antler of red deer, found in quaritity in the upper layers of deposit in the cavern of the Mas d'Azil (Arriège). $B$ and $C$. Imperforate harpoons or lance heads made from reindeer antler of the Magdalenian period (Reindeer epoch). $B$ from Bruniquel Cave (Tarn-et-Garonne). $C$ from a cavern in the Hautes Pyrenées. Same size as the objects.

of these carvings show a mastery of the material, a directness and a simplicity and beauty of essential line, together with true observation of characteristic form, which 
separate these works from those of the ordinary savage of modern times, and have caused living artists of authority to declare that these craftsmen had those definite gifts which entitle them to be recognised as brother artists - an assurance which confirms my own impression based on a long study of large series of the actual specimens. The best works of their later period

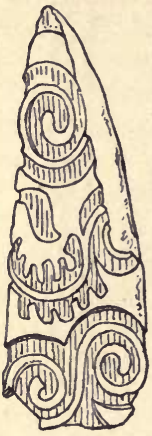

Fig. 69.-A piece of mammoth ivory carved with spirals and scrolls from the cave of Arudy (Hautes Pyrentes). Same size as the object.

(for their skill took time to develop, and follows the laws of growth of all art) represent animals, such as deer, in movement and often turning round or foreshortened (Fig. 70); some of their carvings of horses' heads are worthy of the Parthenon (Fig. 9). On the other hand, as is often observed in primitive art, their representations of the human face and figure are very inferior, and tend to caricature.

We are now in the Palæolithic period, and, what is more, we have quitted what geologists call the recent or modern epoch, and have entered on "geologic" times; this is the Pleistocene or Quaternary epoch. It is a legitimate and useful thing thus to draw a strong line between the Neolithic and the Palæolithic portions of the Stone Age. The Neolithic men belong, so to speak, to our own days. They were, even seven thousand years ago, only a little rougher in their tools than were the peasants of the remoter parts of Central Europe a few hundred years ago. They had not even as much tendency to or gift for artistic work as the ploughmen of 
our own days, and have left none behind them. Excepting that they used stone axes and knives instead of steel ones, they really led the life of mediæval country-folk But once you pass them in your journey backwardsonce you enter the Pleistocene circle-you find that climate, land surface, animals, plants, mode of life are as utterly changed as were you suddenly transferred from the English countryside to Terra del Fuego or to an Eskimo village. The Palæolithic men and their whole surroundings and arts of life have no touch of familiarity for the modern inhabitants of Europe.

When we explore this Palæolithic, Pleistocene, or Quaternary epoch - the last of the geologists' long series of epochs and

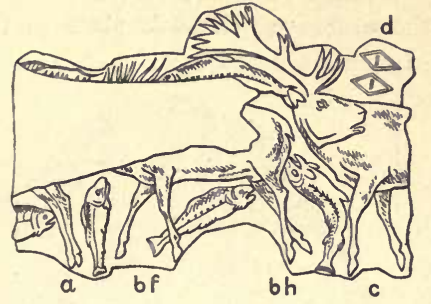

Fig. 70.-Carving on an antler of a group of three red deer and four fishes, remarkable for the attitude and movement of the deer: $a$, hind legs of front deer, the rest broken away : $b f$, second deer : $c$, third deer looking back : $d$, lozenge marks, supposed to be the artist's signature : $b h$, the hind legs of the second deer, wonderfully true to nature in their "hanging" pose. From the cavern of Lorthet, near Lourdes (Hautes Pyrenées), deposit of the Reindeer epoch. The carving runs all round a cylindrical rod of bone (as very many of these carvings do), and is here represented as " un-rolled" or "developed," that is to say, laid out flat. The drawing is a little reduced as compared with the actual carving. deposits-we find that it represents by no means a trivial episode in the world's long change. It is true that compared to geologic periods which follow on below it - namely, the Pliocene, Miocene, and Eocene of the Tertiary, the Chalk and the vast ages below that white sea-sediment, indicated by the sixty thousand feet of 
stratified rock (Jurassic, Triassic, Carboniferous, Devonian, Silurian, Cambrian!), the Pleistocene exhibits but a small thickness of deposit (amounting to but two or three hundred feet of sand and gravel) as its contribution to the earth's crust.

Yet, on account of the nearness to our own times of the events which took place in the Pleistocene period,

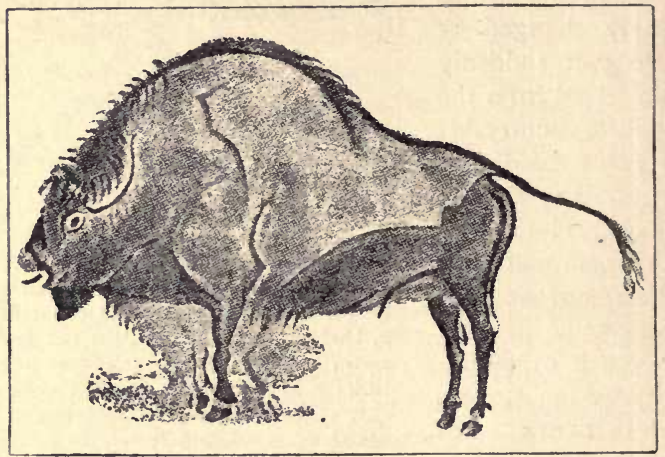

Fig. 71.-Painting of a bison in orange-brown, grey, black, and white, the outline partly engraved, from the roof of the cave of Altamira, near Santander, in the north of Spain, upon which many others as well as wild-boar, horses, and deer are depicted. The original is about two and a half feet long. These drawings were executed by the Reindeer Men in the period of the Upper or Post-Glacial Pleistocene.

geologists and prehistorians have studied its details with minute care, and have accumulated an immense array of facts and specimens by digging and carefully collecting in Western and Central Europe. They have divided up this Pleistocene period and the deposits in river-valley and cave which have occurred within its limits into three great consecutive ages. These are distinguished from one another by the distinctive wild animals which flourished 
in each, by the climate which is indicated, and by the progressive development of the art and workmanship of the Palæolithic men discovered in successive layers of deposit. Let me here refer the reader to the tabular statement on page 384 bis.

These ages of the Pleistocene are:-No. I. The Upper or Post-Glacial Pleistocene, or Epoch of the Reindeer. The climate was cold and dry, like that of the Russian steppes. The contents of the celebrated cave of $\mathrm{La}$ Madeleine, in the Dordogne, and the upper layers of deposit in a whole series of caves (including Kent's Cavern and the Creswell Cave in England) belong to this age. This was the period in which the caves were inhabited by the artistic race "who came no one knows whence, and went no one knows whither," accompanied by the reindeer. Before them there was no carving in the caves, or only very rough work, and we are justified in concluding that the men who inhabited the caves before this period belonged to a totally distinct and inferior race. The "Reindeer Men" must have developed their art by gradual steps before they arrived in the caves of Western Europe-where we do not know. At the end of this period the climate became much milder, and the red deer of our own day took the place of the reindeer, during a long transition in which the "Reindeer Men" and their art disappeared, and the pastoral, land-tilling, stonebuilding, pottery-making communities of the Neolithic Age came into existence, showing no trace of the art of their predecessors. The mammoth and rhinoceros, bison, and aurochs, and, in fact, all the commoner animals of an earlier period were present nearly all through the Reindeer period (they disappear in the late "transition period" of the red deer, called "Azilian"), and were known to the "Reindeer Men," but great herds of reindeer and of horses occupied the grassy lands in this age, which were 
not abundant previously. These herds probably were to some extent protected by the men, whilst the lion, bear, hyæna, mammoths, and rhinoceroses were diminishing in number, and were kept at a distance.

The next lower division of the Pleistocene is No. 2, the Middle Pleistocene or Last Glacial Age, or better,
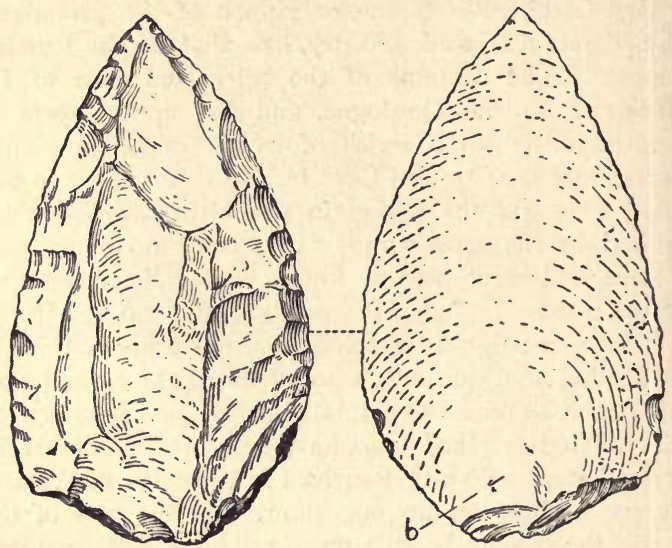

FIG. 72.-Back and front view of a flint implement of the Moustier type (period of the Neander Men or Middle Pliocene), half the size (linear) of the object. Observe the bulb of percussion at $b$, and the completion of one face by a single blow. Note also the fine edge and point of the weapon.

the Epoch of the Mammoth. The climate was cold and humid. For the third and last time great glaciers existed over the whole of Northern Europe, and only bits of the south of England and the central and southern parts of France were free from the icecovering, and carried a rich vegetation. Deeper deposits in caves are of this age, and also much of the 


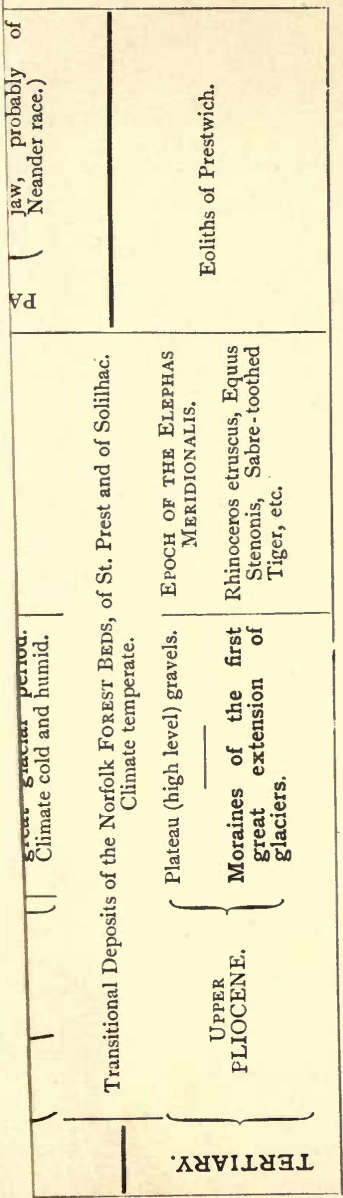

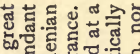

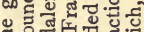
दे ले पू. की है है ल Ч

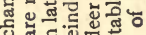
눅.든 들 员出

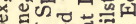
엉 어에

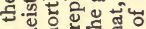
- व

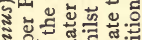
도르

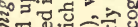

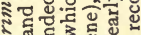

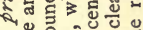

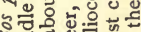

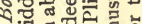
며웛 है ปี

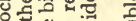

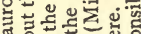
을

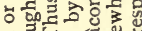

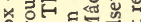

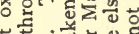

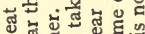

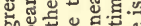
oم 엉

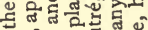

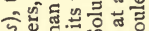

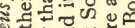

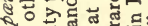
S뭉

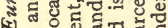

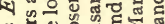
녕요 .

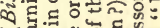

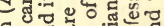
ธี สี 군 (

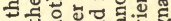

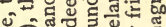

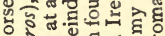

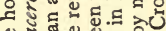

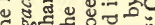

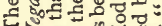

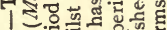
$\infty$ प

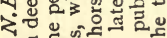
<

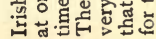




\section{LIBRARY \\ UNIVERSITY OF CALIFORNIA RIVERSIDE}


river gravels of the lower terraces of English and French rivers. By the French it is often called the Moustierian period, because it is well seen in the rich deposits of the caves and plateau of Le Moustier, on the river Vezère (an affluent of the Dordogne), which contain bones of mammoth and rhinoceros, and flint implements of a special form (Fig. 72), but no carvings or artistic work. Hyænas made some of the caverns into their dens, and the cave-lion and the cave-bear were there too. The men of this period actually contested with these carnivors for the possession of the caves, and made great fires to keep out wild beasts, as well as to grill the meat on which they fed. They were of an inferior race to the Reindeer Men, and had not such command of the situation as their successors. We find their remains, their flint weapons, and in rare cases their own bones as well as the bones of the mammoth and hairy rhinoceros (on which they fed), and the bones of their competitors, the hyænas, bears, and lions, in the deeper deposits of some caves, underlying, and separated often by calcareous deposit from, the layers which belong to the subsequent and prosperous days of the Reindeer Men. Most striking is the fact that in the layers of deposit of this older age, there are no works of art nor any implements carved from bone or ivory. These earlier men, devoid of art and living at a low level of savagery, were the Neander Men. It is in this layer and under these conditions that the few broken skulls, agreeing in shape and character with that of the Neander Valley, have been found.

Lastly we come to division No. 3, the Lower Pleistocene, or Epoch of the Hippopotamus. The later climate of this age was mild. It came between two glacial periods, owing to the retreat of the glaciers, which had earlier increased in extent so as to produce the second Great Glacial period. The hippopotamus swam 
in the Thames and Severn in those days, and left its bones and teeth in the older gravels of those and other European rivers, where we now find them. The big almond-shaped and leaf-shaped flint implements of the English (Fig. 73) and French gravels (Fig. 74) belong to this period. We have no knowledge whatever of the men who made them. ${ }^{1}$ The mammoth was not there, but another species of elephant ( $E$. antiquus) and a peculiar rhinoceros ( $R$. merckii). The deepest and oldest deposits in some caves belong to this age, as well as the high-lying gravels of St. Acheuil, of many English rivervalleys, and of Chelles on the Seine. This period is not represented by much deposit in caves, though some caves contain very deep-lying layers enclosing bones or teeth of the animals characterising this period.

Older than the Age of the Hippopotamus are deposits which are reckoned by geologists as "Pliocene"no longer Pleistocene-and are called "Tertiary," not "Quaternary." The forest bed of Norfolk (regarded by Professor Marcelin Boule as of transitional character, as shown in the tabular view on p. 384 bis), the Norwich crag, the Suffolk red and coralline crag, and very extensive sandy deposits all over Europe belong to the Pliocene. The earliest or first great extension of glaciers occurred late in this period. The animals are very different from those of the Pleistocene ; the great mastodon and the tapir are there, and the sabre-toothed tiger. Implements manufactured by man are found in the oldest Pleistocene, and there is no reason to doubt that we shall find his workmanship in the Pliocene, too, though it is not admitted that this has yet been done. It is a question still eagerly studied and debated as to whether the roughly chipped flints found in gravels on high downs in the south of England, and called

${ }^{1}$ See, however, farther on as to the lower jaw found at Heidelberg. 


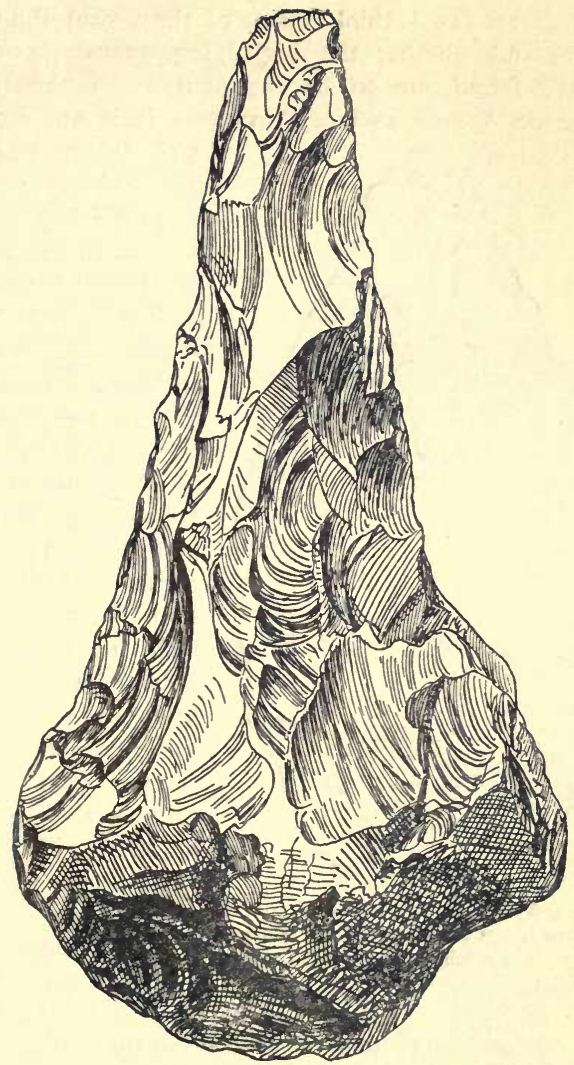

FIG. 73.-Flint pick from the Lower Pleistocene of the Thames Valley. Two-thirds the size of the object. 
"eoliths," are (as I think many of them are) the work of man, and whether the high-lying gravels in which they are found are to be regarded as of the oldest Pleistocene Age or as late Pliocene. It is an exciting

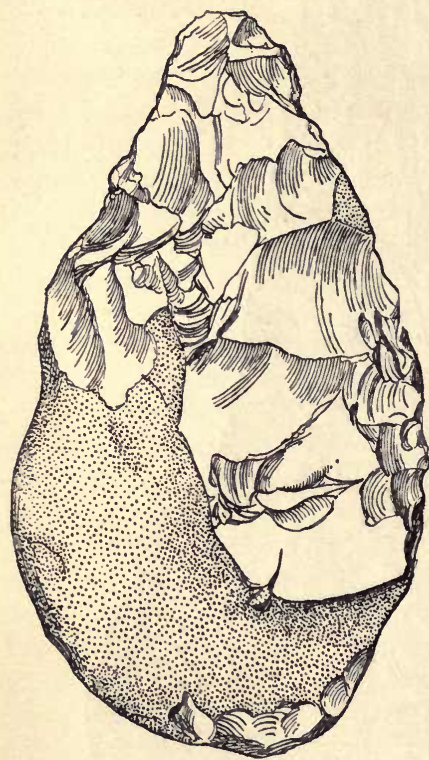

FIG. 74. - A rough type of flint implement from the Lower Pleistocene of the Somme Valley (St. Acheuil). One-half the size of the object. and deeply interesting field of practical exploration and reasoned inference.

It will have been gathered from what I have said that, in seeking for knowledge of the sequence of events in the period of Palæolithic Man, everything depends upon extreme care in removing the deposits from a cave inch by inch, and keeping all objects found distinct from one another and assigned to their proper layer. The same system is now applied with great success to the exploration of ancient cities in Egypt and Central Asia.

As to the actual bones and skulls of men discovered in these Pleistocene deposits, they show us that the Reindeer Men were a fine, full-brained people, as we should expect, with as large a brain cavity on the average as that of modern 

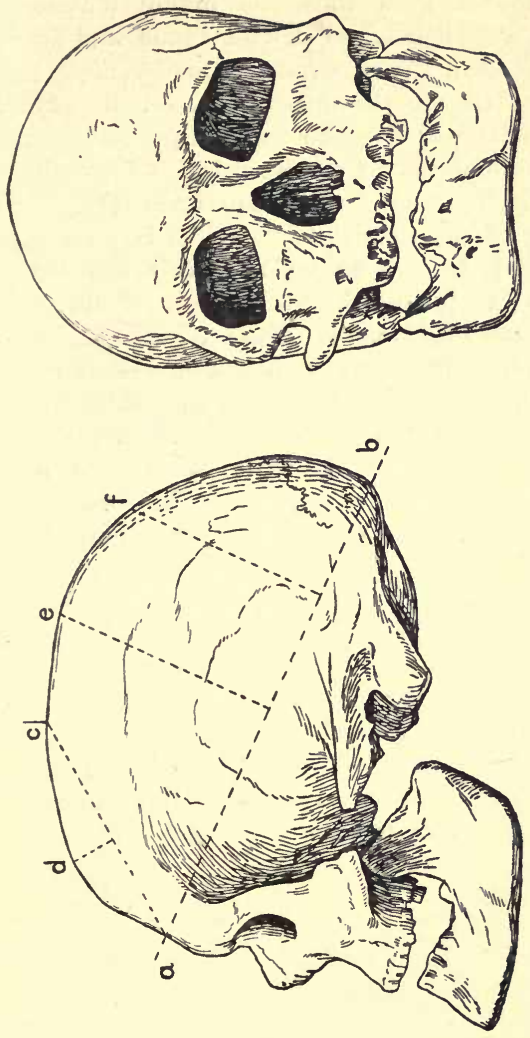

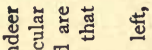

过

\% है :

क ज्ञ के

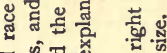

돌 चु

행 के

此熍

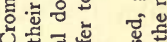

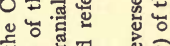

ङ

०े ฮ

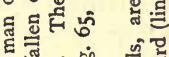

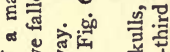

诺

势

矛进

邪

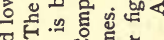

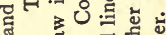

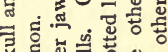

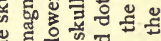

ह है

论式通

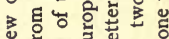

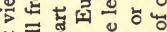

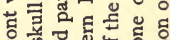

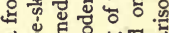
会至品呵 क्षे है कै

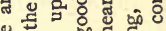
능 의 记

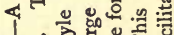
1 皮然运 रं

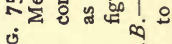
它
से 
Europeans. The skulls of this race, which do not differ in character from those of highly developed modern races, were first found at Cromagnon, and hence we may call them "the Cromagnards" (Fig. 75). The Neander Men are the men of the middle period -the last glacial period-who were displaced by the splendid and accomplished Cromagnards. The Neander Men, of which the new French specimen (Fig. 65) from the cave of the Chapelle-aux-Saints is one, were a very inferior race, and so different from any living race of men as to justify the recognition of them as a distinct species of man, the Homo Neanderthalensis. Only a few other imperfect skulls and skeletons of them are known (Figs. 76 and 77), and show them to have been short people, with very low, flat heads and retreating foreheads. It is in accordance with what one would expect, that they should make no works of art, and should be displaced, as climatic conditions changed for the better, by the arrival of the fine, full-brained Cromagnards or Reindeer Men. But where did they, these delightful artists and happy hunters of the Reindeer Epoch, come from? We cannot say. And what became of them? We do not know. They did not give rise to the Neolithic race, but were replaced, turned out by that race. To them, indeed, are appropriate the words of the Roman poet-Prolem sine matre creatam, mater sine prole defuncta 


\section{XLII}

\section{THE CAVE-MEN'S SKULLS}

\section{CERTAIN number of human skulls and a few com- A plete skeletons have been found in the cave-deposits,}

and even in open ground (as at Predmont, in Moravia) associated with the bones of extinct animals, or with carvings and ornaments like those which occur abundantly in the caverns. The ancient cave-men of the Cromagnard type - often called "the Reindeer Men"-buried their dead sometimes in the caves, but more usually in the open. Sometimes the skeletons are found in a crouching position, as though tied up when buried; more rarely (as in some examples found in the caves at Mentone) they are stretched out and decorated with a necklace or wreath made of shells, or of the teeth or small bones of animals. In many cases the flesh was removed from the corpse, and red ochre was smeared on the bones (as by some recent savages). The "Reindeer" people used red ochre and charcoal to colour the engravings of animals (Fig. $7 \mathrm{I}$ ) which they made on the walls of their caves, and probably for painting or tattooing their own faces. The existence of these wall paintings, wonderful representations of bison, great ox, deer, and other animals, proves that these men had artificial light (lamps or torches) to send fitful gleams on to the paintings, and it is probable that the "wall pictures" had to do with some kind of witch- 


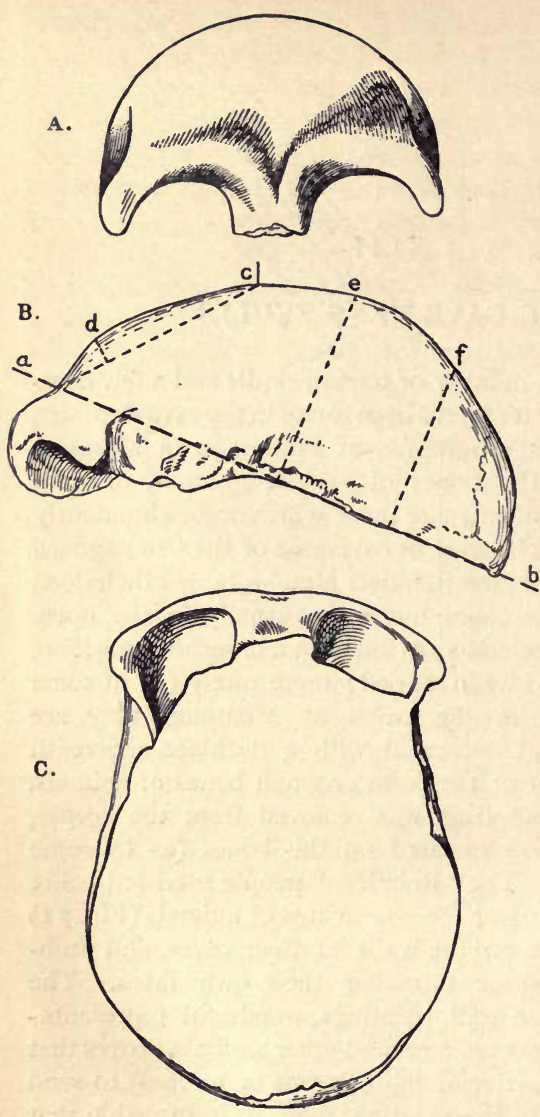

Fig. 76.-Three views of the skull-top from near Elberfeld on the Rhine, known as the Neanderthal skull(Middle Pleistocene, Mous. tierian, or last Glacial Period : epoch of the Mam. moth). These figures are partly copied by kind per. mission of Mr. Worthington G. Smith, F.L S., from excellent figures published by him in his interesting book, Man, the Primitive Savage (Stanford, 189g). In all respects the measurements of this skull-top agree very closely with those of the skull from the Chapelleaux-Saints. $A$. A view from in front. $B$. Side view showing the line $a-b$, and the other lines, $a-c, d, e$, and $f$, exactly as in Fig. 65. The shallowness of the cranial dome and the small projection of the frontal boss $d$, agree exactly with the measurements of the Chapelle skull shown in Fig. 65. $C$. View of the skull-top from below. This gives the outline of the Neander. man's skull as seen from above, and shows the curious vizor-like expansion of the ridges over the orbits, the pinching in just behind them, and the elongate shape of the skull, with its great breadth in the hinder region. The French skull from the Chapelle agrees exactly in outline with this, and in both the volume of the cranial cavity given by this large expanse amounts to 1600 cubic centimetres, in spite of the flatness of the cranial dome-a greater volume than that of the Cromagnon skull drawn in Fig. 75 , or of the average modern European. 
craft. Stone lamps have actually been discovered in the caves. Their ceremonial treatment of the dead shows that already the lines were laid for that worship of the "spirits of the departed," which became general, and is especially familiar to us in the comparatively modern civilisation of Rome and the Etruscans. There is also evidence that they made simple musical instruments.

In the cave-deposits of the Post-Glacial or Reindeer Age, the human skulls and skeletons which have been found (not indicating more than thirty or forty individuals altogether from widely separate localities) show a very well-developed race, with large brain-case (Fig. 75), quite equal to that of modern Europeans. Some of these men were very tall, one of the skeletons from the Mentone caves being that of a man $6 \mathrm{ft}$. $3 \frac{1}{2}$ in. in height. The cavity of the skull (which corresponds very closely in size with that of the brain which it contained) would hold about 1550 units of water (the unit referred to is a cubic centimetre, 1550 of which are equal to a little less than two and a half English pints). It is not surprising that these Reindeer Men had fine brains, for their carvings and pictures show them to have been real artists, not mere savage scrawlers. This race is called the "Cromagnards," after the first skulls discovered at Cromagnon, in Central France. They had big, strong lower jaws, with prominent chins, like many fine modern races (e.g. the New Zealanders), and fine, narrow noses. The face and upper jaws were somewhat prominent, though not nearly so much so as in modern negroes. The skull-bones were thick and strong. The brain-case or cranial part of the skull was oblong rather than round.

The skulls of the older race-that of the Last Glacial or Moustierian Age-the Neander Men, were 
long skulls, too, but had a peculiarly flattened shape and a retreating forehead. The bony ridges over the eyes, corresponding to the eyebrows, were enormous, and projected forwards like the vizor of a cap (Figs. 65,76 , and 77). There are but few specimens to guide our conclusions, but they show that though of short stature (some not more than $5 \mathrm{ft}$. 4 in.), these people were very muscular. The top of a skull from the cave in the

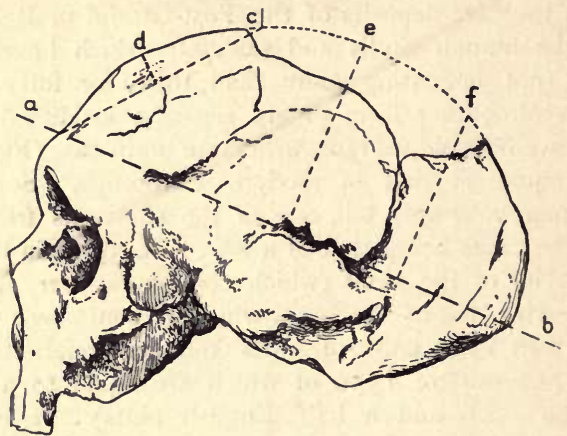

FIG. 77. - The Gibraltar skull from a cave in Gibraltar, now preserved in the Museum of the Royal College of Surgeons, London. It is of the Neander race. Compare the dotted lines and lettering with those of Fig. 65, and the explanation there given. The drawing is one-third (linear) of the natural size.

Neander Valley, known as the Neanderthal skull, two imperfect skulls from the cave of Spy, in Belgium, an imperfect skull from Brunn, in Moravia, and other fragments from Krapina, in Croatia, and, lastly, one from a cave in Gibraltar, are the best known. Others, including fragments of several skeletons less fully described, which have been found at Predmort, in Moravia, probably belong to this race. But the newly obtained skull and bones from the centre of France (Chapelle-aux-Saints) 
are the most important of all yet discovered. They all date from the middle Pleistocene period, the age of the last great glaciers, earlier than the age of the Reindeer. The Gibraltar skull (Fig. 77) we have all known for a long time; it has been in the museum of the Royal College of Surgeons for forty years, and two years ago was very carefully examined and figured by Professor Sollas, of Oxford. It is a specially valuable specimen, because it shows the bones of the face as well as the brain-case. From other specimens we know the lower jaw. The lower jaw was deep and powerful, but, like that of an ape, had a receding chin, or rather, we should say, had no "chin-prominence" at all (compare Figs. 79, 80, $8 \mathrm{I}$, and 82). The new French specimen (Fig. 65) is strongly prognathous. The orbits are enormous, and the nose very flat and quite unique in its great breadth. One of the two Neander-man skulls from the Belgian cave of Spy shows the face bones, and these agree with what has just been stated as to the French skull.

Hence it appears that a short race with a very strange and low-browed type of skull preceded the men of the Reindeer Age. When, thirty years ago, only the original skull-top from the Neander cave (Fig. 76) was known, Virchow, of Berlin, considered it to be probably that of an idiot, whilst Huxley expressed the opinion that it indicates a race of men with decidedly low development, and in some respects more ape-like characters than modern Europeans; but he held that it is not to be considered as "a missing link," nor as taking us appreciably nearer from modern man to the apes, since it is most closely approached by the flat skulls, already well known, of some of the South Australian natives, both in shape and in the cubical capacity of the braincavity. What I mean by the flatness of the skull may be understood by looking at a side view of a monkey's 
skull (Fig. 81) and of an ordinary European human skull (take the Cromagnon skull as equivalent, Fig. 75) placed upright, so that the eyes are looking forward. If in an outline or photograph of each of these skulls you draw a straight line from a point between the eyebrows back to a point just below the most projecting ridge of the hindermost region of the skull, you will find that above that line in the monkey's skull is a slightly curved surface - the roof of the brain-case. But in the human skull above the similarly drawn line the roof bulges so as to form an almost hemispherical dome, rising sometimes vertically in the front region to form "the straight, high forehead" (which Shakespeare commended, even in woman). It swells out in the hinder region also. Now the Neander skulls, and to a less extent the skulls of many of the Australian aborigines, are more like the monkey's in this matter; the dome of the roof is shallow and flat, and the forehead does not rise up, but slopes backwards, so that the whole contents of the brain-case are lessened by the reduction of the frontal and upper region. And there is reason to consider this frontal region of the brain as specially connected with some of the higher intellectual qualities of the mind.

We know a little more about the skull of the Neander race since Huxley wrote, owing to the further discovery of specimens. The Australian's skull has usually a more projecting upper jaw and upper front teeth than has the Neander Man's. The Neander skulls stand alone in the great breadth of the orbits and of the nasal region as compared with all known skulls. They are also alone (the Gibraltar skull and the new French specimen are the only ones which show it) in the contour of the upper jaw. In other human skulls there is a broad depression of the surface-a nipping-in, as it werebehind the root of the canine tooth on each side. This 
is absent in the Neander race; the bone here is flat, and not in-pushed. This absence of " modelling," absence of the canine "fossa" or valley (as it is called), is seen in the larger apes as well as in the Neander Men. This point does not show in our figures. Some writers think it probable that the Neander Men of the late Glacial Age were the ancestors of the Cromagnards of the Reindeer Age, and also that the artistic Cromagnards were transformed, after many thousand years, into the comparatively dull and inartistic people of the Neolithic period. It seems to me, on the contrary, more probable (as is held by some of the French prehistorians) that the Reindeer Men died out, and were replaced by the Neolithic herdsmen who migrated into Western Europe as the climate became milder. The notion that the Esquimaux of to-day are the Reindeer Men of France who have migrated northwards with their reindeer, following the receding ice, has been entertained, but is regarded by the most careful inquirers as untenable. As to the earlier change of race, I hold that it is not possible to contend that the Neander Men developed into the Cromagnards of the Reindeer Age actually in the south of France. If the lower race or species gave rise to the higher, the enormous transformation did not occur here nor in Europe at all, nor during the later Pleistocene period. Human skulls of the Reindeer Age are known which present an approach to the characters of the Neander race, such as the heavy bony eyebrows. But it seems that this is accounted for by the survival of some Neander families alongside of the powerful Cromagnard men and the interbreeding of the two. The Cromagnards had probably lived with their reindeer in some more southern area during the late Glacial Age, and arrived in southern France as the climate improved and became suitable to their accustomed quarry. How and where they de- 
veloped from a lower type of men we have at present no indication.

A very remarkable discovery of the last five years made in the course of the careful excavation of the four caverns of Mentone by the Prince of Monaco, where as many as sixteen human skeletons of the Pleistocene Age have been brought to light, gives us a new point of view as to the presence of more than one race in Europe in these immensely remote times, as in later periods. In one of the caves, and in a position showing them to date from the deepest layer of the middle Pleistocene, or late Glacial Age, two complete skeletons have been found (and may be seen alongside those of the Cromagnon race in the museum at Monaco), which are obviously different from those of both the Neander and the Cromagnon people. They have skulls which decidedly resemble that of the modern negro race, so that they have been definitely assigned to a new race hitherto unknown in European caves, and are spoken of as "the negroid skeletons" and " the Grimaldi race." This is indeed a startling fact. There was land stretching across the Mediterranean in those days, and these skeletons suggest that already there was a negroid race in Africa, individuals of which had wandered north as far as the maritime Alps. ${ }^{1}$ Two or three negroid skulls of Neolithic (therefore very much later) Age have been found in Brittany and in Switzerland. When we reflect that the negroid skeletons of Mentone and those of the contemporary Neander Men are probably more than 100,000 years old, we are at once impressed with the important conclusion that already in that remote period three great branches of the human race had come

1 In this connection it seems to be important to note the "Ethiopic" character of the arrangement of the hair in the little carving of a woman's head from the Brassempouy Cave (dep. Landes), shown in Fig. 7. 
into existence-the negroid, the Neander, and probably, at a more distant spot, also the highly developed Cromagnards. The origin of the really primitive race of man is thrown back in time by these facts to a still more remote period, in fact, to an earlier geologic epoch. And it is to be noted over and above these facts that we have no indication as to where the much later race, the Neolithic Men, came from, nor who were their contemporaries outside the European area; nor again do we know where the historic races who succeeded the Neolithic Men took their origin. When other regions of the earth have been examined as carefully as Western Europe has been, we shall no longer be in such complete darkness.

When one ventures to speculate as to the story of the earliest men in Europe, one can but feel, even after handling the specimens and carefully following the excavations, how small and fragmentary and difficult to interpret is the evidence at present brought to light. And yet there the evidence is, gathered with the utmost care and intelligent method, discussed and interpreted by men of rare knowledge and experience, who, after long comparison of contending opinions and the discovery of an ever-increasing body of fact, have arrived at a definite certainty as to the sequence of arts, races, animals, and climates which I have given above, and is again summarised in the tabular statement on page 384 bis.

Hereafter these conclusions will be modified and extended by excavations in other parts of the world, at present untouched. The one point upon which the best authorities will not commit themselves is the exact, or even approximately exact, number of thousands of years which these events have occupied. The whole story, so far as it is at present worked out, is a marvellous result of patient research and scientific reasoning. Some 
of the cave collections upon which it is based are to be seen in London, in the British Museum.

There is one other discovery of a fossil man which comes properly at this point, to cap and confirm what has already been said. Fifteen years ago a skull-top and a thigh-bone were found by Dr. Dubois at Trinil, in the island of Java, at a depth of thirty feet in a sandy deposit, considered by good authority (but not certainly) to be of Pliocene age. From recent reports on the deposit it seems that it may very well be of Pleistocene age.

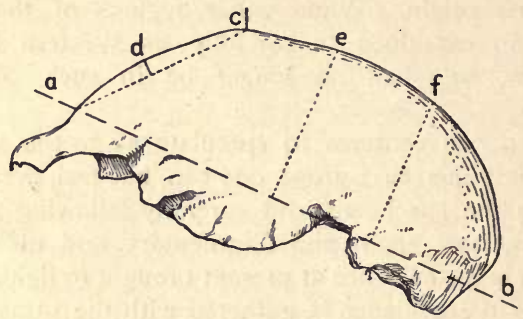

FIG. 78. -The skull-top of the primitive kind of man from Pleistocene sands in Java, called Pithecanthropus. One-third (linear) of the natural size. Compare with Fig. 65, and refer to that figure for the explanation of the letters and dotted lines.

These remains have become celebrated as those of a monkey-like man, and the name Pithecanthropus has been given to the creature to which they belonged. This skull-top (or cranial roof) is now in Utrecht, and is well known (Fig. 78). It indicates a race of men or men-like creatures, with the flatness of skull, receding forehead, and large bony eye-ridges, such as we see in the Neander Men and in some South Australians, but greatly exaggerated. The skull was so low and flat as greatly to resemble that of the Gibbon, though much larger. The volume of the cranial cavity (showing the size of 
the brain) was about 900 units-far smaller than that of the average Australian-the skull of smallest cavity among living races of men. The volume of the braincavity of the largest ape (gorilla) amounts to about 500 units (cubic centimetres); so that, allowing for rare individual fluctuations of as much as one-fourth more or one-fourth less (an amount of variation which, great as it is, is definitely known and recorded in specimens of the skulls of human races), we get the following list of "cranial capacities" or brain-sizes, forming a nearly unbroken series between the highest European and the ape. The middle figure represents the normal or average, and the first and last figure in each group the constant, though rare, minimum and maximum. Gorilla, 350, 500, 650; Java race, 675, 900, I I 25; Australians, 900, 1200, 1500; Cromagnard and European, I I65, I 550 , I 940 (European skulls of this great capacity are known). The Neander-man skulls are left out of the above listalthough the Corrèze specimen allows of a satisfactory measurement of its capacity - for a very curious reason, which is explained in the next chapter. 


\section{XLIII}

\section{MORE ABOUT THE NEANDER MEN}

SINCE writing what precedes I have been able more D than once to gratify my keen desire to examine the wonderful human skull from the Chapelle-aux-Saints in the Corrèze (Central France). The skull has been photographed, and an excellent figure of it is reproduced in our Fig. 65. But it is one thing to look at a picture of such a specimen, and another to take it into one's hands and closely examine it. The skull is in the care of my friend, Professor Marcelin Boule, who is at the head of the great collection of remains of extinct animals in the Jardin des Plantes.

It has been treated by him with great skill so as to render the bone firm and hard, whilst detached portions have been fitted into place, so that it is fairly complete (Fig. 65). The skull was found (together with many bones of the skeleton of the same individual) by two enthusiastic local archæologists buried at such depth and in such position in the cave known as the Chapelleaux-Saints as to leave no doubt as to its belonging to one of a race of men contemporary with the mammoth and hairy rhinoceros - a race which inhabited Europe in the great glacial period-called by prehistorians "the Moustierian period," which cannot be less than a hundred thousand years behind us, and probably is more. The 
chief importance of this skull lies in the fact not only that its position in the cave-deposits, and therefore its relative age, was carefully ascertained, but that it agrees in its very peculiar form with the Neanderthal skull (from the Rhineland), the Spy skulls (Belgium), and the Gibraltar skull. It, in fact, confirms the conclusion that at this period the caves of Western Europe were inhabited by a race of men with peculiar skulls, which may be called the Neander race in reference to the firstdiscovered skull of the kind. They were altogether different from the Reindeer Men, or Cromagnards, who came later upon the scene.

The fact was published some four months ago that the new Corrèze skull agrees with the celebrated skulltop (called a "calvaria" by anatomists) of the Neanderthal (Fig. 76) in the extraordinary shallowness or absence of "dome," in the retreating forehead, the thick prominent eyebrow ridges, and in the excessive "lowness," or want of elevation of the back region. But further study of the new skull has enabled Professor Boule to show, as he demonstrated to me, that the outline of the new skull looked at from above coincides not merely approximately, but exactly with that of the Neanderthal skull. There is the same great length from eyebrows to occiput, and the same great breadth at a series of corresponding regions. The curious thing is that both these skulls are of enormous size-a good deal bigger in length and breadth than modern European skulls, and not small and ape-like, though they are far shallower (that is, less high in the dome) than any skulls of living men. I had, myself, always been astonished by the great breadth and length of the casts of the Neanderthal skull which we possess in England, and supposed that possibly the casts were carelessly made. Now Professor Boule shows that both the 


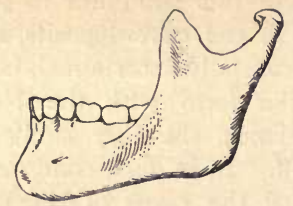

FIG. 79. - Drawing one-third the size of nature, of the left side of the lower jaw of a modern European. Observe the small size as compared with the jaw in Figs. 80,81 , and 82 , also the prominent chin : the small breadth of the up-turned ramus, and the deep bay or notch (not seen in the other lower jaws) separating the coronoid process from the condyle.

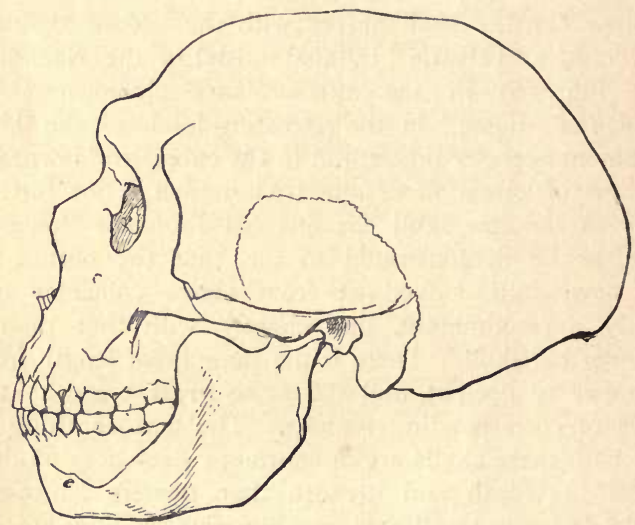

FIG. 80.-Outline (one-third the size of nature) of the skull of the Neander Man from the Chapelle-aux-Saints, with all fractures and defects made good. The bony sockets of the teeth and the teeth themselves (lost and atrophied by inflammatory disease in the actual skull) are here given their full size and healthy condition. The lower jaw is seen to be very similar to that from Heidelberg (Fig. 82). From a photograph taken by Professor Marcelin Boule from a cast of the actual skull. The cast was "made good " by modelling upon it the deficient parts. 


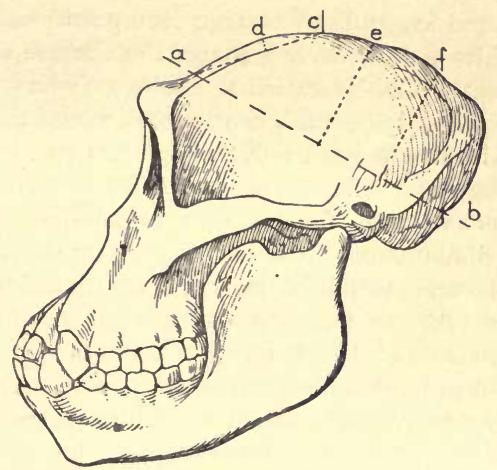

FIG. 81.-The skull of a male chimpanzee. Drawn one-third the natural size (linear) to compare with the human skulls and jaws here figured. The dotted lines and the letters $a, b, c, d, c$, and $f$ have the same signification as in Fig. 65, to which reference should be made. The flatness of the cranial dome and the reduction of the frontal boss $(d)$ are very marked. So are the relatively large size of the jaws and teeth. Compare the shape of the lower jaw with that from Heidelberg (Fig. 82), and with that of a modern European (Fig. 79).

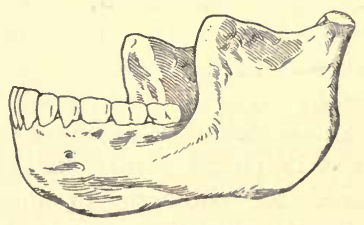

FIG. 82. - The Heidelberg jaw, from a lower Pleistocene deposit, near Heidelberg. Observe the absence of chin and the great breadth of the up-turned part of the jaw. Compare with the lower jaws drawn to the same scale in Figs. 79, 80, and $8 \mathrm{r}$. One-third the size of nature. 
Neanderthal and the Corrèze skull are so much larger in breadth and length than average European skulls, that in spite of its flat, depressed shape, the Corrèze skull (and consequently the Neanderthal skull, too) has a braincavity holding 1600 cubic centimetres, whilst the average modern European skull only holds 1500 to 1550 . The estimate given by former observers for the Neanderthal skull was as low as I 200 . This calculation was based on the diminution of volume caused by the flatness of the skull, and would be correct were the skull of the Neander race no longer or broader than an ordinary European skull. If we imagine a skull of the ordinary European proportionate height, but as long and as broad as the Neander skulls, then its volume would be something like 2000 cubic centimetres. This is a very remarkable result. The ancient Neander Men's brain was not smaller, but actually a little bigger than that of modern Europeans; it was bigger in regions where the modern European is small, and smaller where that is large!

If we had any sufficient knowledge of the mental qualities which belong to different regions of the brain (if, indeed, such localisation of qualities is possible), we might draw some interesting conclusions from this difference between the two races. But unfortunately our knowledge on that matter is very defective. We are not in a position to say that length and breadth of the brain either can or cannot compensate (so to speak) for shallowness. It is probable that the mental qualities of the two forms of brain were in important respects different, but that is all that can at present be said. No accredited brain student would, until more is known, venture to draw conclusions as to mental quality from such facts as mere breadth, length, and depth of the cranial cavity. 
The Corrèze skull has a strongly-projecting face, depending not merely on a protrusion of the dentary border of the upper jaw, but on a forward thrust of the entire face. This is not shown by the Gibraltar skull (Fig. 77). It is not improbable that this region has been flattened in the Gibraltar skull whilst it was buried in the cave deposit and softened by water. The lower jaw is preserved in the new French specimen, and is very remarkable on account of the retreating chin and the lowness and backward flexion of the articular process, as well as for the large size of the surface by which it articulates with the skull. All the cheek-teeth have been shed (see Fig. 65), and the sockets closed owing to inflammation, showing that primitive European man was subject to the same trouble with his teeth from which civilised men of to-day suffer. In comparing the skull with the skulls of modern races, Professor Boule is not inclined to insist much on the resemblance to Australian and Tasmanian skulls presented by the thick and large brow-ridges. A careful study of the skull is giving to Professor Boule many facts of importance which will be published ere long. The articular surfaces or "condyles" of the skull (for instance) by which it was set on the neck vertebræ are so set that the head must have been habitually carried with a droop like that of an animal, and not poised upright on the neck as in modern races of man.

Not less important than the skull are some of the bones of the arm and leg. Indeed, they show more novel characters than the skull, and definitely distinguish the Neander Men so as to justify us in regarding them as a distinct species, Homo Neanderthalensis. The thighbone is very short: as compared with that of a modern European, it is as 14 to 18 . Also it is thick and curved. This was already known in the Neander Man of the Spy 
cave, and its confirmation by the specimen from the Corrèze establishes this shortness of the thigh as a specific character. There are also strange features in the articulation of the bones of the thumb and of the heel which Professor Boule will make known when he publishes his full account of this most astonishing skeleton.

It is worth noting here that another skull of the same race_that of a young individual - was dug out in 1908 at Moustier by Mr. Hauser, a Swiss explorer. The specimen was broken into many fragments and has not been satisfactorily put together, so that at present it is not possible to say whether it gives any further information as to the Neander Man. Also in 1909 the French explorers have found another skull and skeleton of the same age and race at Ferassi, near Moustier, on the Veyzere. It has been carefully removed, but not yet studied. The bones of the hand and of the foot are complete, and will be available for confirming the observations made on the skeleton of the Chapelle-auxSaints.

We have, a few pages back, noted that behind the Glacial or Moustierian period of the Pleistocene (the second of our list, the Reindeer period being the latest), geologists recognise a third or warm period which is represented by deeper cave-deposits and by some of the older sands, clays, and gravels of our river valleys. As in the Moustierian deposits, so in these older deposits (called "Chellean" after a French township) we find abundant large flint implements (Figs. 73, 74) indicating the presence of man. But the animals associated with him were not the mammoth and the hairy rhinoceros; they were the Elephas antiquus and a distinct kind of rhinoceros, and most distinctively the hippopotamus. These beds and their animal remains and worked flints occur abundantly in the South of England, and have 
been more or less mistaken for and confused with the glacial Moustierian deposits which also are common in England. No bones or skulls of the men of this Chellean period have been found, excepting a lower jaw, which was not long ago discovered in a deposit of this warmer and earlier age, near Heidelberg (Fig. 82). This jawbone is remarkably well preserved, and the great difference between it and that of a modern European may be seen by comparing our Figures 79 and 82 . In the absence of chin, the great breadth of the up-turned part of the jaw and the shallowness of the notch separating the condyle or articulating knob from the more forwardly placed "coronoid" process (a well-marked triangular process in the modern European jaw), the Heidelberg jaw differs from the modern European, and resembles that of the chimpanzee (Fig. $8 \mathrm{I}$ ).

Dr. Schoettensack of Heidelberg, who has described this remarkable jaw-bone and has very kindly presented casts of it to the Natural History Museum, to Oxford, to Cambridge, and to myself, was of the opinion that it indicated a distinct race or even a distinct species of man. But Professor Marcelin Boule has found that when the lower jaw of the skull from the Chapelle-auxSaints is " reconstructed," not only by replacing the parts broken away, but by restoring the teeth and the absorbed sockets of the teeth, it comes out very closely identical with the Heidelberg jaw. In Fig. 80 I have reproduced the profile of Professor Boule's complete restoration of the "Chapelle" skull, and it will be seen that the lower jaw differs very little from that of the Heidelberg specimen. Indeed, Professor Boule has published a photograph in which he attaches the Heidelberg lower jaw to the restored Chapelle skull in place of its own, and the similarity of the two becomes very obvious.

As will be seen by the drawings which I give here, the 
Heidelberg jaw is even more powerful than that of the Chapelle skull. The lower jaw of a modern European (Fig. 79), drawn to the same scale as the other two, and as that of the chimpanzee (Fig. $8 \mathrm{I}$ ), is an elegant little thing with its forwardly-projecting chin, its short measurement from front to back, and the narrowness and delicacy of its up-turned part or ramus, with its well-marked angle at the lower corner and deeply cut upper border between the condyle (hindermost projection with knob) and the coronoid.

The imperfect lower jaw (without teeth and with the articular condyle broken away) of the Cromagnon skull, drawn in Fig. 75, should also be compared : it is, though broken, similar to that of the modern European. Lower jaws differ in some of the points which we have been looking at, from one another, but there is no known living race of men the lower jaw of which is not far nearer to that of the modern European (Fig. 79), than to that from the Chapelle-aux-Saints or from Heidelberg (Fig. 82); and I may add that the imperfect lower jaw of the Neander-man skull, from the Spy Cave in Belgium, agrees in the absence of chin and in other points with that of Heidelberg and of the Chapelle skull. There is not sufficient ground afforded by the characters of the lower jaw for considering that the race indicated by the Heidelberg specimen was distinct from the Neander race, as may be seen by comparing Fig. 80 with Fig. 82 .

As these pages are going to press, I am able to add that $I$ have seen in Paris a very interesting and striking restoration of the appearance in the flesh or during life of the head of the man of the Chapelle-aux-Saints, carefully modelled in Professor Boule's laboratory by a young sculptor, by applying his clay to a cast of the completed restoration of the skull. It is, I understand, proposed to publish this restoration firstly as strictly 


\section{MORE ABOUT THE NEANDER MEN 4II}

determined by anatomical fact and devoid of hair, and then to add the hair of the scalp, the eyebrows, eyelashes, and beard, and to place artificial eyes in position. We shall thus get a representation of this ancient race or species of man, based on the sure foundation of the actual bones. Fanciful portraits of "primitive man" have before to-day been produced by some imaginative artists, but this will be the first portrait of him with an inner framework of truth. 



\section{N DEX}

Amœba, term applied to proteus animalcule, 194

Andrews, discoveries of, with regard to ozone, 252

Animalcules, bell, unicellular structure exemplified in, 197-199

ciliated unicellular, graceful movements of, 207

dried, examples of "suspended animation" in, 168, 169

proteus, processes of protoplasm in, 195

sun, processes of protoplasnı in, 195

unicellular plants and, essential differences between, 204207

Animals, aquatic, excess of egg production to ensure survival to maturity, 143, 144

aversions and cautious proceedings of, 269

blindness of, congenital, 272, 273

colour-protection and invisibility of, 304,312

"concealment" and "warning" marks, distinction between, 310-313

destructive invasions made by various, 339, 340 .

devices adopted for protection of young by, $138,139,144$

domesticated, reasons for continued congenital defects in, 27I, 272

hibernation of, 165,166

lower, various thread-producing, 293,294

mankind and, causes of congenital defects in, 273

\section{Animals-continued}

parthenogenetic powers possessed by certain, 330, 33I

poisonous, methods of self-protection used by, ror

"warning" coloration possessed by, 107

propagation of, 132-137, 144-145, 329-330

sleep of, salient features connected with, 16I-164

structure of multicellular and unicellular, comparisons between, 207-208

unicellular, uses made of cilia by, 194-197, 207

wild, congenital defects less obvious in, 271, 272

wood-boring, 346,347

Anopheles Gnat, 3

Ants, aphides and, friendship

Aphides-

enemies of, 319, 325

hop-blight caused by species of, 317,319

parthenogenetic propagation of, $326-327,330,334,336$

rapid propagation of, 326,338

relationship of Coccide to, 322, 323

secretive productions of, $323-325$

various species of, 322

Archrology, discoveries in connection with pre-historic man, 37I372 , 391, 394-395, 398, 400, 402

Art, knowledge compatible with, 45

Astronomers, stupendous nature of work, 224 
Astronomy, Halley's discoveries in connection with, 226

Newton's discovery of law of gravitation as affecting, 230 photography as affecting study of, 222

spectroscope as affecting study of, 224,225

Atavism, feeble-mindedness resulting from, suggestion as to, 274

Athletes, experiments as to possible use of pure oxygen by, 260263

Auzout, M., astronomical predictions attempted by, 229, 230

Bacon, Lord, quotation from, I, 14

Bacteria, destructive invasion made by, 340

microscopic observation of, improvement in, 239

Balfour, Rt. Hon. Arthur, speech at Manchester by, 6, 7 (quotation)

Bananas, cultivated varieties of, 369 plantains and, identity of, 368

Bayeux tapestry, 23I

Becquerel, M., experiments of, 183

Beetles, book-worm, depredations of, $350-351$

death-watch, tapping made by, $351,35^{2}$

wood-boring, 351,352

wood-boring, 349-350

ladybird, beneficial activity of, $319,325,326$

origin of name, 325

perforation of soft metal by grubs of, 353

Bell-animalcules, 197

Birth-rate, increased, amongst poorer classes, 285,286

Blood, lack of red colour in, cause of, 148,149

red-coloured, cause and special duty of, 148

Bonaparte, Prince Roland, French representative at Darwin Centenary Celebration, 39

Book-worm beetle, 350

Boulenger, Charles, Egyptian freshwater jelly-fish described by, 64
Boys, C. V., fine quartz threads spun by, 294, 295

Caddis-worms, movable cases made by grubs of, 343

Calandruccio, discovery of young of the eel by, $7 \mathrm{I}-72$

Cambridge-Darwin Centenary Celebration, Address by Sir Ray Lankester at, 33-37

held at, I8, 33, 38

notable representatives at, 33 , 38,39

Cave-men, ancient, artistic skill of, 8o, $8 \mathrm{I}$

horse mastered and muzzled by, 80, 81

Caves, care taken in excavation of, 388

discoveries of human remains in deposits of, $371,374,383$, $393,395,402,407-409$

discovery of bones of ancient men in, rarity of, $372-374$

French and English, evidences of human occupation found in, 78-79

Cells, definition and origin of term, I 70-I 73, 328

egg-cell, process of fertilisation, 202-204, 330, 332

important part played by nucleus in life of, 198-200, 328, 329.

individual character and coordinated activity of, 170, I $80-182$, I 84,328

process of division, $200-202,328$

" Cell-theory," explanation of Pro. fessor Schwann's, I 74-176

Chapelle-aux-Saints, discovery at, important, 371, 374, 390, 402

Children, feeble-minded, number attending schools provided for, 278

result of neglect to provide supervision for, 279-28I

China, introduction of opium smoking into, 366,367

Chinese primrose, similarity between poisonous properties of Rhus toxicodendron and, 104 
Cholera, bacillus of, organisms favour: ing or checking growth, 242 , $243,246-249$

carriers of, 245

causes of, 237

Metchnikoff's and Pettenkofer's experiments in connection with, 240-34I

definition of word, $237,23^{8}$

germs, destruction of, 244,245

Indian, active development of sanitation in Great Britain, due to panic caused by, 239 date of first appearance in England, 238

diffusion through water-supply, 239

discovery by Koch of bacillus producing, 240

epidemic nature of, 238

Europeans first attacked by, 238

recognition of, by Hindu writers, 238

precautions to be observed for prevention of, 244, 245, 246

Cholera-bacillus. See Cholera

Christmas fare, origin of, $356-35^{8}$

Cilia, animals provided with, and action of, 194, 195, 207

definition of term, I94

uses made of, by unicellular animals, 195-197, 207

“Cirrhipedes," Darwin's discovery with regard to, 23,24

Civilisation, scientific knowledge as affecting, 16

Clothes moths, 34I

Coccida, relationship of aphides to, 323

Colour, in bird's feathers, 55,56

nature and properties of light as affecting, 52-55

Comets, ancient records of, exaggeration in, 227, 229

composition of, 234, 235

Donati's, imposing size of, 227 early superstitions with regard to, 227,228

elliptical orbits of, 233

Halley's-Chinese astronomical observations relating to antiquity of, 230

length and breadth of orbit, 233

length of tail, 227
Comets-continued.

Halley's-continued.

predicted recurrences by discoverer of, 226, 230

recent appearance of, 226, 230, 236

significance of date of return, 228,229

superstition and consternation caused by, 230, 231

William the Conqueror's "star," identical with, 231

important, various, 227

Milton's reference in Paradise Lost to, 228, 229

periodic and wandering, distinction between, 233, 234

photographs obtained at Royal Observatory, Greenwich, of new, 225, 226

shooting stars and, connection between, 235, 236

signification of name, 227

superstitions with regard to, 229

Corrèze skull, 371

Cromagnards, designation of Reindeer men as, reason for, 390

Cuba, measures adopted for prevention of yellow fever and malaria in, 2,3

Darwin Centenary Celebration at Cambridge, $18,33,38$

Darwin, Charles-

comparison between theories of Lamarck and, -19, 20

connection with University of Cambridge, 36

establishment of "natural selection" theory, 34

extent of time spent in experiments and observations, 18 19, 22-23

friendly relations between Wallace and, 13,37

geological discoveries of, 24

Henslow's influence upon, 36

"Natural selection" theory explained, 27-29

study of disease influenced by discoveries and research of, 39,40

Darwinism (Wallace), 15, 16 (quotation) 
Death-rate, diminished, reasons accountable for, 284,285

health of locality determined by, 283

records of, methods of keeping, 283,284

Death-watch beetle, 351, 352

De Lastic, Vicomte, carvings from caves in collection of, 79

Dewar, Sir James, experiments of, 183

Divers, Mediterranean, suggested inhalation of pure oxygen gas by, 26 I

Diving, Fleuss apparatus, diluted oxygen supply to, $263-265$

Donati's comet, 227

Dragon, heraldic, description of, I I, II 5

Dragons, classification of, by heralds, 120

conventional, probable sources of, I 26

probable origin, 121-123

snakes and, connection between, 120-123

tradition of, reasons for discrediting suggested, rr 8-120

Drugs, individual variability (idiosyncrasy) with regard to, 102

Eau-de-Cologne, volatile oils from aromatic plants of Riviera used in manufacturing, 47

"Eel-fare," term for annual "running up" of young eels, 67 , $70,73,75$

Eel-fisheries, regulation and encouragement by Danish Government of inland, 65

German Government of inland, 65,66

Eels, age of, knowledge resulting from power of telling, 69 shown by scales, 69

common, period when change from "yellow" to "silver" takes place in, $67,69,70$

reproduction, migrations and habits of, 66-67, 69-76

"leptocephalus-young-phase" or tadpole of, 7I-73, 75

migrations of, geological changes as affecting, 74

\section{Eels-continued}

Petersen's researches with regard to "silver," 68,69

popularity of, abroad, $6 j, 66$

rare occurrence of, in river Danube, 74,75

" Elvers," term for young eels, 66, $67,70,71,73,75,76$

Europe, iron, stone, and bronze ages of, $375-377$

Evelyn, diary of, 229 (quotations)

Feeble-minded, distinctions between lunatics and, 274-276

laws relating to lunatics and, need for improvement in, 275

necessity for state guardianship of, 276-278

Feeble-minded children, 278

Feeble-mindedness, atavism suggested cause of, 274

hereditary transmission of, 277

occurrence of cases in all classes of community, 276

views of Government Commission on origin of, $28 \mathrm{I}$

Festivals, Christmas, origin of children's customs associated with, $361-362$

English Christmas, introduction of turkey in connection with, $35^{8}$

origin of heavy feeding at, 357

prehistoric and barbaric customs in connection with, 356-357

Fever, yellow, comparative deathrate from, in Panama Canal zone, 2-4

measures adopted in Cuba and Panama for prevention of, 2,3

Fish, shell-fish and, individual susceptibility to poison from, 102, 103

Fishes, age of, method of telling, 69

poisonous, 103

poison-spines of, 107, II I

Fixed stars, 221

Flack, Mr. Martin, experiments of, with regard to oxygen gas, 260

Fleuss apparatus, 263-265

Flowers, perfumes discharged into the air by, various effects of, 105, 106 
France, cultivation of purple variety of poppy in, 364

French archæologists, leading discoveries with regard to prehistoric man made by, $37 \mathrm{I}$, 372

Frogs, common, eggs of, 209, 212 growth from the egg, 213-215 English species, 216

European species, 216, 219 green tree-frog of Riviera, 49, 50, 52,55

method of catching prey, 219

Furniture worm, 351, 352

\section{Gases-}

oxygen, action of ordinary, 259

experiments as to possible use by athletes, $260-263$

Fleuss diving apparatus and diluted supply of, $263-265$

ozone, destructive powers of, 253

discoveries of Andrews and Tait with regard to, 252

experiments of Schönbein with regard to, 251, 252

methods of producing, 252, 253, $25^{8}$

nature of, 252

proportion of, to fresh country or sea-coast air, 253

result of experiments with regard to, 259

signification of name, 252

therapeutic value and uses of, 258,259

use in water-purification, 256 , $25^{8}$

Geology, Darwin's discoveries in, 24

table showing history of man in Western Europe, 384 bis

Germany, custom of eating preserves with meat in, prevalent, $35^{8}$ predominance of scientific knowledge in, 8

Gnats, Anopheles, malaria germ carried by, 3

Stegomyia, yellow fever germs carried by, 2, 3

Gorgas, Colonel, work of, in connection with yellow fever and malaria, 2-5

"Gossamer," origin of term, 289
Grassi, discovery of the history of the eel by, 70-72

Green-flies, 322

Green tree-frog, 49,50

Griffin, heraldic, 116

Guinea-pig, native home and original introduction of, $360,36 \mathrm{I}$

various names given to, 360,361

Halley, Edmund, astronomical discoveries of, 226

date of death, 230

foundation of Royal Society Club by, 230

law of movement of comets discovered by, 226, 230

Milton and, scholars of St. Paul's School, 228, 229

Newton and, friendship of, 230

Halley's comet, 226, 230

Hansen, leprosy-bacillus discovered by, 240

Hay fever, individual susceptibility to, 102, 104, 105

probable cause, 105

similarity between vegetable poisonings and, 105

Heart, action of nervous system upon, in man and higher animals, 151

muscular contraction, cause of, I50, 151

rate of beat in higher and lower animals, 1 52-154

in human species, 151,152

significance of its beat, 147,148

valves, action of, 149

Hedge-sparrow, 267

Henslow, Professor, Darwin as influenced by, 36

Herschel, Sir John, definition of word "species" by, 14, 15

Hertwig, Professor, German representative at Darwin Centenary Celebration, 33

Hill, Dr. Leonard, experiments of, with regard to use of oxygen gas, $260-265$

Hipparion horse, $84,85,86$

Hippopotamus age, 380,386

Histology, origin of 176

Hook, Robert, Micrographia by, 173, 288,289 
Hooker, Sir Joseph, Darwin and Wallace papers communicated to Linnean Society by, 12, 13

IIop-blight, causes of, 317-319

prevention of, 318, 319

Hop-louse, 317

Hops, brewing industry as affecting growers of, 321

cultivation of, 315-316

curing of, 320

English growers as affected by American and German hopplantations, 320, 32I

uses made of, 315

Horses, absence from American continent in fifteenth century of living asses, zebras, and, 89

ancestral, change in size and proportions of, 84,85

lower Tertiary Hyracotherium, 84

middle Tertiary, 84

"pre-orbital cup" in Hipparion, 85,86

upper Tertiary Hipparion, 8486

ancestry of, scientific points of interest with regard to, 8390

descent from Arab ancestry evidenced by presence of "pre-orbital cup" in, 86

English thoroughbred, history and ancestors of, 82, 90

"Ergot" of, 89

European, stock from which derived, 77-78

fossil remains of extinct, in North and South America, 89, 90

mark of difference between asses, zebras, and, 87,88

mastery and muzzling of, by ancient cave-dwellers, 8o, 81

Mongolian wild, absence of "preorbital cup " in, 86

derivation of European horses from, $77-78$

description of, 78

prehistoric European, verified by ancient carvings found in caves, 79-8I

\section{Horses-continued}

selective breeding of, from time of cave-men onward, 82,83

Southern or Arabian breeds of, presence of "pre-orbital cup" in, 86,87

House-sparrows, 266

Huxley, Professor, calculation of, with regard to fecundity of plant-lice, 338

Hydra, heraldic, derivation of, 116

Hyracotherium horse, 84

India, practice of opium eating in, 366

Infants, blindness of, congenital, 272

mortality of, varied congenital defects causing, 272

Insects, association of, with plants, 296

colour-protection and invisibility of, 304-312

destructive invasions made by various, $339-345$

jumping bean as exemplifying association of plants and, 297, 298-300, 302

parthenogenetic powers possessed by certain, 33I, 332

poisonous, methods of self-protection used by, IOI, IO2

various weapons of, III

" silver-fish," depredations of, 351

skin burrowing, I I2, II 3

wood-boring, 346-354

Jelly-fishes, common, description of, 58

fresh-water, discovery of African, 61,62

Chinese, 63

Philadelphian, 63, 64

Regent's Park, 59, 60

reproduction of, 60,6 I

poison-bearing threads of sea. anemones and, Iro

Jumping bean, Mexican, caterpillar contained in, 229, 300, 302

movements of, 298, 299, 302

plant from which derived, 301, 302

relationship of insect and plant exemplified in, 297, 298300,302 
Kew Gardens, beauty and interest of, 302,303

specimens of Rhus toxicodendron at, 93, 94

Koch (Berlin), cholera-bacillus discovered by, 240

tubercle-bacillus discovered by, 240

Ladybird, 325

Lamarck, inferiority of scientific methods, as compared with Darwin, 19-22, 26

Philosophical Zoology by, 20

Lankester, Sir Ray, address by, Darwin Centenary Celebration at Cansbridge, 33-37

Leprosy, bacillus of, discovery by Hansen, 240

" Leptocephali," discovery of, 70-72

Life, protoplasm the seat of, $182-184$, 328

Herbert Spencer's definition of, $\mathbf{1} 8_{3}$, 184

Light, rate at which it travels, 22 I

Locusts, winged serpents and, probable connection between, 124-125

Lunatics, distinctions between feebleminded and, 274-276

laws relating to feeble-minded and, need for improvement in, 275

Lyell, Sir Charles, Darwin and Wallace papers conimunicated to Linnean Society by, I2, 13

Malaria, comparative death-rate from, in Panama Canal zone, 2-4 measures adopted in $\mathrm{Cuba}$ and Panama for prevention of, 2, 3

Mammoth age, 380,386

Man, sleep of, compared with repose or quiescence of other living things, I 59-16I

Mankind, congenital defects in, causes of, 273

Mental defect, 274

Metchnikoff, Professor, discoveries with regard to use and value of " phagocytes," 39

experiment by, in connection with cholera-bacillus, 24I
Metchnikoff-continued

experiments and investigations of, for prevention of "senile change," 40-43

influence of Darwin's discoveries upon study of disease by, 39,40

researches of, with regard to microbian flora of localities, 249

Russian and French representative at Darwin Centenary Celebration, 33, 38

Tolstoi's meeting with, 43, 44

use of sour milk prepared with lactic ferment introduced by, 4I, 42

Micrographia (Hook), 173, 289

Microscopes, improvements in, I73, $176-178$

Milton, celebration of tercentenary ot birth, Halley's comet in relation to, 228

Halley and, scholars of St. Paul's School, 228, 229

Mistletoe, pre-historic rites associated with, 362

Mollusca, animals classed as, and definition of word, 129

Molluscs, protection of young, 137I39, I44, I46

Mongolian wild horses, 86

Morley, Lord, installation of, as Chancellor of Manchester University, 6

Morphia, product of opium poppy, 363

Moths, British species allied to Mexican "jumper," 300 301

clothes, mischief effected by cater pillar of, 34 I-343

movable case made by cater pillar of, 34I-343

propagation of, 34I

various species of, 343-345

Mexican "jumper," 300, 301

silk threads produced by cater pillars of certain, 293

Mountain-climbing, use of oxygen gas in, suggested, 263

Moustierian period, definition of, $384,385,408$ 
Moustierian period-continued

skulls and skeletons found in cave-deposits allotted to, $37 \mathrm{I}, 385,393-395,406$, 408

Mussels, pond and river, propagation of, 144,145

protection of young, I44

Mycenæ, discovery of, by Schliemann, 16

Neander men, comparison between skulls of Australian aborigines and, 396, 397

inferiority of, as compared with Cromagnards, 390

reasons for recognition of, as distinct and primitive species, 371, 385, 390, 402403,407

Neolithic Period, civilisation comprised in, $377-378,380$

\section{definition of, 377}

Nettles, poisonous stinging hairs of, I03, 104

Newton, Sir Isaac, discovery of law of gravitation, 230

Halley and, friendship of, 230

Opium, derivation of word, 364

eating, practice in India of, 366

medicinal value of, 368

poppy used for manufacture of, 363 , 364

smoking, introduction by Chinese of, $366-367$

Osborne, Professor, United States representative at Darwin Centenary Celebration, 33

Oxygen gas, 259

Oysters, care of breeding, methods adopted for, $14 \mathrm{I}$

classification of, 129

common, protection of young, 134 , 144

destruction of typhoid germs in, I28, 129

French "green," 141, 142

gill-plates or "beard," I3 I

growth and maturity of, 134, 136

heart and blood-vessels, I 32

lake, cultivation by ancient

Romans, I4O, 141

nervous system, 132
Oysters-continued

primeval man and, 139

propagation of American and Portuguese species, 137, I 43 , I 44

common or North Sea and Channel species, 132-137, 143

structure and nature of, $129-137$

Ozone gas, $25 \mathrm{I}$

Palæolithic period, definition of, 377 period of chipped flints, primitive arts and surroundings of, 378-381

Panama, measures adopted for prevention of yellow fever and malaria in, 2, 3

Perrier, Edmond, French representative at Darwin Centenary Celebration, 39

Petersen, researches of, with regard to " silver" eels, 68,69

Pettenkofer (Munich), experiment by, in connection with cholerabacillus, 240

" Phagocytes," use and importance of, 39, 179

Philosophical Transactions, date of first published number, 229

Philosophical Zoology (Lamarck), 20

Phylloxera, 336

injury and loss caused by, 334, 337

introduction into Europe, 337

parasitic nature of, 337

propagation of, 336,337

Piette, M., carvings from caves in collection of the late, 79,80

Planets, changes on, probable result of, 223, 224

Plant-lice, 322

Plants, American, poisonous stinging hairs possessed by certain, IO 4

association of, with insects, 296

jumping bean as exemplifying association of insects and, 297, 298-300, 302

movements of, definite and varied, 160,161

poisonous, special chemical substances produced from, 100

use of, in manufacture of Eau-deCologne, I00, I0I 
Plasmogen, formation of, 190-192

Pleistocene period, discovery of remains belonging to, 383 , 385,386

skeletons, found in caverns of Mentone, 398-399

epochs, table of, 384 bis

Pliocene period, discovery of remains belonging to, 386,388

distinctions between Pleistocene and, $386-387$

Poisonous animals, 101

fish, 103

insects, 102

plants, 92, 100, 104

Poisons, distinctions between gutpoisons and wound-poisons, 106-107

immunity from wound-poisons, method of producing, 107, 108

Poppies, cultivated variety from which opium manufactured, 363

cultivation of, in remote ages, 364 , 365

earliest cultivation of, for oil, 363 , 364

English varieties of, 363

opium, introduction from Europe into Far East of, 363-365

origin of medicinal uses of, 364,365 Population, increased, due to higher birth-rate amongst poorer classes, $279,285,286$

Post - Tertiaries (or Quaternary), gravel and cave-deposits termed, 83

Proteids, building up of, in plants, 204, 205

cell-protoplasm consisting of, 189 , 190

chemical composition of, 188,189

"Proteus," definition of term as applied to unicellular animals, 193, 194

Protoplasm, chemical elements contained in, 187

death caused by destruction of, $183-185$

active life of, $182-184,328$

explanation of term, 170-172, 328

Quaternary (Post-Tertiaries), 384 bis
Reindeer age, 384 bis

Reindeer men (or Cromagnards), artistic work of, 383,390 , 391, 393

brain cavity of, comparable with modern European, 388, 390

customs of, 391, 393

skulls and skeletons of, found in cave-deposits, 391, 393

Rhus toxicodendron, American poisonvine or, poisonous nature of, 92

case of poisoning by, recorded in The Spectator, 96

differences and resemblances between Virginian creeper, Veitchii, and, 93

individual susceptibility to poison of, $94,96,102$

painful malady produced in certain persons by poison of, 91, 92

recognition in United States and Japan of danger of, 92, 98

results of examination in laboratory at University of Harvard (Mass.), with regard to, 94

similarity between poisonous properties of Chinese primrose and, 104

specimens at Kew Gardens, 93, 94

use in Japan, 92

Riviera, cultivated trees and plants of, $47-49$

flowers for sale, cultivated in, 56,57 green tree-frog of, $49,50,52,55$

meteorological conditions of, 46

primitive vegetation of, 46,47

tree-frog, blue variety of, 50,52 , $53,55,56$

vegetation of, influence of man upon, 57

Salamanders, European species, various, 218

Mexican, various species of, 215 , 216

Sanitation, active development in Great Britain, cholera panic as affecting, 239

Schliemann, discovery of Troy and Mycenæ by, 16 
Schönbein, experiments of, with regard to ozone, 251, 252

Schwann, Professor, "cell theory" of, explained, 174-176

Science, discoveries in, satisfaction experienced by those making, I

sensibility to art compatible with capacity for, 44

state officials' opposition to, 286

value and importance of, 7,8

Scorpions, poison of, experiments with regard to, 108-I Io

Sea-anemones, poison-bearing threads of jelly-fishes and, i 10

Serpents, winged, probable connection between locusts and, 124-1 25

worship and propitiation of, 122123

Shell-fish, poison-glands of, I I I

boring in stone, 347,348

Siebe, Gorman and Co., perfected diving dress constructed by, 265

"Silver-fish" book-worm. See Insects

Skulls, ancient and modern, comparison between, 410

comparison between, of various periods, 393-40I

Corrèze, comparison between Neanderthal and, 403-406

discovery of, 37 r, 374, 390, 402 restoration of, 4I0-4I I

European, compared with Neanderthal and Corrèze, 406

Sleep, alternation of night and day in its bearing upon periodic, 1 57-1 58, I 59, 167, I 68

animals' winter, I65, I66

artists' varied portrayal of, 156, I 57

definition of term, varied, 1 57-161

irregularities and abnormal manifestations of, I64-166

length and duration of, conditions affecting, 166-167

man's, compared with repose or quiescence of other living things, r 59-16r

salient feature connected with, 16I164

Shakespeare on, 155, I56 (quota-
Snails, whelks and propagation ot, $137,1_{3} 8$

protection of young, 137,138

Snakes, dragons and, connection between, 120-123

winged serpents, and probable origin of, 12I-125

Solar system, comparative distance from "fixed stars," 22I-222

Sound, rate at which it travels, 22I

Sparrows-

hedge and house, distinction between, 267

differences between, 266-268

cuckoo eggs laid in nests of, 266 , 267

use to agriculturists, 267

house and tree, close connection between, 268

harm done by, 267, 268

hidden or latent capacity in, 268

probable effects of destroying, 268

various species related to, 268

Spectator, The, case of poisoning by $R$ hus toxicodendron recorded in, 96

Spiders, garden, use made by astronomers of thread of, 262,263

gossamer threads of minute autumn, $287-289$

spinnerets of, 289-29I

threads produced by, various uses made of, 289-292

various species of, 289

Spurges (Euphorbiacea), various species of, $30 \mathrm{r}$

Star-fishes, propagation of, 329-330

Stars, early superstitions with regard to, 227,228

fixed, comparative distance of solar system from, 22 r

estimated number of, $\mathbf{2 2 2}$

measurement of, 225

"photographic," estimated distance of, 223

shape of, 231, 233

"Vega," position of, 224, 225

Stegomyia Gnat, 2, 3

Stings, poisonous, American plants possessing, $\mathrm{IO}_{4}$

comparison between plants and animals possessing, 97, 106

nettles and other plants provided with, 103,104 
Stone-borers, shell-fish and worm, 347-349

" Suspended animation," examples of, 168,169

Symbolism, legendary monsters in relation to, 125, 127

Tadpoles, food of, 211 , 212 growth and development of, 210, 211

gigantic, 218

Tait, discoveries of, with regard to ozone, 252

Tapestry, Bayeux, representation of Halley's comet in, 231

Tertiaries, the, sand and clay deposits termed, 83

Thayer, Abbott, colour-protection and invisibility of animals as demonstrated by, 306-312

Throughton, use of spider's lines in telescopes introduced by, 292

Tissue, explanation of term, 174

Toads, English species, 216

European species, various, 216-219 gigantic tadpoles of spur-heeled, 216-218

method of catching prey, 219

Tolstoi, Metchnikoff's meeting with, "Toxin," 43,44 conversion into "antitoxin," 102

Trees, English, derivation of various, 57

Tree-sparrows, 268

Trout, "natural selection" theory in relation to increased caution of, 269,270

Troy, discovery of, by Schliemann, I6
Tubercle - bacillus, discovery by Koch, 240

Turkey-cock, native home and original introduction of, $35^{8-359}$

various names given to, 359

Two on a Tower (Hardy), quotation from, 220

Unicorn, heraldic, origin of, 127

Universities, extension and diffusion of science by, need for, 6 , 8,9

Oxford and Cambridge, reasons for inefficiency of, 10

Oxford and Cambridge, result of usurpation by wealthy classes, 9 , 10

Upas-tree, Java, fabled effect of, 96

"Vega," position of our sun and planets with regard to star, 224,225

Village population, increasing degeneracy of, 270, 278, 279

Wallace, Alfred Russel, Darwinism by, 15, 16 (quotation)

friendly relations between Darwin and, 13,37

theories of, 12-14, 26

Wood, protection against "worm" and "mould," methods advocated for, 354,355

" worm-eaten," production of, 349

Wood-borers, animal, 346-347

death-watch beetle, 351-352

furniture beetle, $348-350$

Worms, stone-boring, 347-349

Wyvern, heraldic, 116

Yellow fever, 2-4 
Printed by

MorRison \& GibB Limited

Edinburgh 


\section{METHUEN'S \\ POPULAR NOVELS}

AUTUMN 1912

\section{THE HEATHER MOON}

By C. N. and A. M. Williamson, Authors of 'The Lightning Conductor.' Third Edition. Crown 8vo, 6s.

The story of a motor tour in Scotland and many quests. The drama shows us a girl in search of her mother, who has her own reasons for not wishing to be found by a pretty grown-up daughter. A man in search of some lost illusions is also here, and the girl helps him to discover that they are not illusions but splendid truths. Other seekers are a woman in search of love, and her brother in search of materials for a novel. In finding or failing to find these things a romance of a very original kind with many conflicting interests has been evolved.

\section{LONDON LAVENDER : An Entertainment}

By E. V. LucAs, Author of 'Mr. Ingleside.' Third Edition. Crown 8vo, 6s.

This is Mr. Lucas's fourth novel, or 'Entertainment' as he prefers to call his stories; and readers of the preceding three may find some old acquaintances. The scene is again laid principally in London, and again an odd company of types converse and have urbane adventures.

\section{BURIED ALIVE}

By Arnold Bennetr, Author of 'Clayhanger.' A New Edition. Crown 8vo, 6s.

This is a reprint of one of Mr. Bennett's most delightful stories. It has been out of print for some time.

\section{THE STREET GALLED STRAIGHT}

By the Author of 'The Wild Olive.' Third Edition. Crown 8vo, 6s.

The anonymous author of those very interesting novels The Inner Shrine and The Wild Olive has in the new book dealt with a financial man's case of conscience. The story, which is laid for the most part in Boston, illustrates the New England proverb, 'By the street called straight'-should it not be strait?-' we come to the house called beautiful.' 


\section{DARNELEY PLACE}

By Richard Bagot, Author of 'Donna Diana.' Second Edition. Crown 8vo, 6s.

The scene of Mr. Richard Bagot's new novel is laid partly in England and partly in Italy. The story turns upon the double life led by a wealthy English landowner in consequence of the abduction in his more youthful days of the daughter of an old Italian house at a period when he had no prospect of succeeding to the position he subsequently attained. Incidentally, the novel deals with certain phases of Italian Spiritualism, and Mr. Bagot's readers will again resume their acquaintance with some of the most sympathetic characters described in his previous work, The Passport.

\section{LAMORNA}

By Mrs. A. Sidgwick, Author of 'The Severins.' Second Edition. Crown 8vo, 6s.

The story of two girls united by kinship and affection, but divided by character and temperament. Lamorna, the elder one, has to look on while her cousin makes a tragedy of her life and successively becomes the victim of a roué and a mischief-monger. Lamorna's own fate is at one time so enmeshed with her cousin's that she requires all her sense and strength to escape from the toils set by a man who would override all scruple and all honour to win her.

\section{THE QUEST OF THE GOLDEN ROSE} By John Oxenham, Author of 'The Long Road.' Third Edition. Crown 8vo, 6s.

By 'The Golden Rose' the author means the Spirit of RomanceLove-and all that pertains thereto. The story tells how three very typical Englishmen - surgeon-artist-barrister-encounter it in odd fashion while tramping the High Alps, and follow it up each in his own peculiar way to his destined end. Their various testings, mental, moral, and physical, make the story, which is replete with the joy, the sorrow, and the tragedy of life.

\section{THE HOLIDAY ROUND}

By A. A. Milne, Author of 'The Day's Play.' Second Edition. Crown 8vo, 6s.

Among our younger humorists none has so quickly found his way to the hearts of readers as 'A. A. M.' of Punch, whose special gift and privilege it is to touch Wednesdays with irresponsibility and fun. $\mathrm{He}$ has now brought together a further collection of his contributions to Punch, similar in character to The Day's Play published two years ago. The history of the Rabbits is continued, and is supplemented by 'Little Plays for Amateurs,' 'Stories of Successful Lives,' and many other of his recent dialogues and sketches.

\section{DEVOTED SPARKES}

By W. PETr RIDGE, Author of 'Thanks to Sanderson.' Second Edition. Crown 8vo, 6s. 
Mr. Pett Ridge's new novel, an animated story of London life, concerns a girl sent out to service by her stepmother. Taking the management of ber career into ber own hands, and holding the reins, she goes first to a house on the north side of Regent's Park, afterwards to the neighbourhood of Berkeley Square; and her adventures in both situations, her acquaintances, and the person to whom she is devoted, are described in Mr. Pett Ridge's brightest manner.

\section{THE ROYAL ROAD : Being the Story of the Life, Death, and Resurrection of Edward Hankey of London}

By Alfred Ollivant, Author of 'Owd Bob.' Crown 8vo, 6s.

In the pages of this book the reader follows the courageous spirit of a working man down the alley of life. We hear his laughter; share his joys; and watch the heroic struggle of his soul against the circumstance that is oppressing him. The book, remorseless in its representation of things as they are, is strong in hope : for it finds its inspiration in the Love that shall some day conquer the world. It is a story for all who seek to succour our England in her distress. A stern book, it is to those who read aright a joyful one. For it is a prophecy of dawn.

\section{SALLY}

By Dorothea Conyers, Author of 'Two Impostors and Tinker.' Third Edition. Crown 8vo, 6s.

A hunting novel of Irish life. The scene is laid in the wilds of Connemara, where a man suffering from melancholia starts hunting over the mountains and the bogs. A seaside lodge close to him is taken by some strangers, and the plot of the book then turns on the lonely man, who has not spoken for years save when obliged to, being charmed from his loneliness by Sally Stannard, and the subsequent complications which ensue betwixt her and her various lovers.

\section{OLIVIA MARY}

By E. Maria Albanesi, Author of 'The Glad Heart.'

Third Edition. Crown 8vo, 6s.

In this, her first new novel to be published since The Glad Heart, Madame Albanesi strikes new ground. Although full of able and sympathetic characterization and that elusive charm which belongs to all her books, this story is unlike any that she has yet written. The author deals with a problem which is the outcome of emotions at once simple, even ordinary, and yet at the same time profound and most touching.

\section{THE BIG FISH}

By H. B. Marriott Watson, Author of 'Alise of Astra.' Third Edition. Crown 8vo, 6s.

This strange tale of adventure in the mountains of Peru has a certain basis in fact. 'The Big Fish' is the name by which the lost treasure of the Incas is known, and the story describes the search for it, which opens in a London auction room and, after many tragic adventures, ends in the lonely mountains in a manner which neither of the seekers had anticipated, but with which both are satisfied. 


\section{THE ANGLO-INDIANS}

By Alice Perrin, Author of 'The Charm.' Third Edition. Crown 8 vo, 6 s.

The background of this novel is the contrast between official life in India and a pensioned existence in England. The theme of the story is the affection, almost amounting to a passion, that the heroine feels towards India, where she has spent part of her childhood and her early girlhood; it leads to a love adventure involving the chief problem between the East and West.

\section{MARY PEGHELL}

By Mrs. BeLloc Lowndes, Author of 'The Uttermost Farthing,' etc. Second Edition. Crown 8vo, 6s.

In her new novel Mrs. Belloc Lowndes returns to the manner of Barbara Rebell. It is an ample, spacious tale of English countryhouse life, laid in a quiet Sussex village, dominated by the ruins of an ancient castle, the scene of the last Lord Wolferstan's lawless but not ignoble passion. The writer shows all her old power of presenting the passion of love in each of its Protean phases. Mary Pechell herself is a lovely, gracious figure, whose compelling charm the reader feels from the first. In half-humorous, half-pathetic contrast is the middle-aged romance of Miss Rose Charnwood, touched with the tenderest sentiment, and not belied by the happiness in store both for her and for Mary Pechell herself.

\section{THE SUBURBAN}

By H. C. BAILEY, Author of 'Storm and Treasure.' Second Edition. Crown 8vo, 6s.

In this novel Mr. H. C. Railey, who is best known by his spirited historical romances, has deserted the past for the present. He tells a story of modern London. The scenes are laid in poor middle-class life, in the worlds of journalism and theoretical revolutionaries and business. His hero is one of the most ordinary of men, fighting his way up from the borders of poverty to respectable suburban comfort. With him is contrasted a much more brilliant creature, an apostle of the newest creeds of revolt. Both have to do with the master of one of the great modern organizations of finance and industry. In the heroine Mr. Bailey has given us a study of one of the newest types of young women of the middle class.

\section{THE HAPPY FAMILY}

By Frank Swinnerton, Author of 'The Young Idea.' Crown $8 v 0,6 s$.

The Happy Family is a realistic comedy of life in London suburbs. The scenes are laid principally in Kentish Town, with excursions to Hampstead, Highgate, and Gospel Oak ; while unusual pictures of the publishing trade form a setting to the highly important office-life of the chief male characters. The interplay of diverse temperaments, the conflict between the ideal and the actual, are the basis of the story, which, however, is concerned with people rather than problems. 


\section{REMITTANGE BILLY}

By Ashton Hilliers, Author of 'Memoirs of a Person of Quality.' Second Edition. Crown 8vo, 6s.

In this book Mr. Ashton Hilliers, again finding his material in the world we live in, tells of the quite excusable muddling of a straight, but rather stupid young gentleman, whose ignorance of 'business' is too severely punished by 'business-like relations,' who regard him as hopeless, until he, saved by his love of nature, and befriended by outsiders who see stuff in the fellow, muddles through, to the surprise of his family and himself. There is a nice girl in it, and a militant suffragette, but only two unfortunate marriages, and one of these comes right at last.

\section{A KINGDOM DIVIDED}

By David Lisle, Author of 'A Painter of Souls.' Crown 8vo, 6s.

This new novel by the author of $A$ Painter of Souls may be described as actively controversial. It deals largely with poignant chapters in the life of a young clergyman, and in its pages we find an amazing array of startling facts connected with the march of Ritualism and the future of England. Side by side with the history of a tragic struggle we find glowing descriptions of scenery and of brilliant social life. The scene is laid in Devon, and, later on, at Biarritz.

\section{JUDITH LEE : Some Pages from her Life}

By Richard Marsh, Author of 'A Royal Indiscretion.' With Four Illustrations. Second Edition. Crown $8 \mathrm{vo}, 6 \mathrm{~s}$.

The world has already been introduced to the famous female detective Judith Lee in the pages of the Strand Magazine, where her popularity was very great. The child of parents who were teachers of the oral system to the deaf and dumb, as soon almost as she learnt to speak she learnt to read what people were saying by watching their lips. Devoting her whole life to the improvement of a very singular natural aptitude, and employing it in the discovery and frustration of crime, she has become, as we find in this book, a constant source of wonder and delight, and a very encyclopedia of adventure.

\section{THE SILVER DRESS}

By Mrs. George Norman, Author of 'Lady Fanny.' Crown 8vo, 6s.

A novel describing the life of an attractive and still young woman whose circumstances are those of so many others of her type in England, for she has no acquaintances but women, is approaching 'the youth of middle age' without yet knowing love or any vital interest. Then, quite unexpectedly, adventure, and, subsequently, love coming to her, she lives for the first time. 


\section{HAUNTING SHADOWS ; or, The House of Terror}

By M. F. Hutchinson. Second Edition. Crown 8 vo, 6s.

An English girl, brought up under harsh surroundings, considers that opportunity suddenly opens the doors of Life. But these doors swing back to the accompaniment of sinister and terrible things. The very threshold of the new life is a place of terror. A harsh and inexorable fate forces her reluctant feet along a difficult way, where it seems as if none of the joys of existence can lighten the darkness. The story shows with what results to herself and others Elaine Westcourt became an inmate of the 'House of Terror.'

\section{THE FOOL IN GHRIST}

By Gerhart Hauptmann. Crown 8vo, 6s.

A translation of Hauptmann's most wonderful novel-a work that attempts to place the living human Christ before sophisticated twentiethcentury eyes. Whatever other effect it may have, the book cannot fail to cause discussion. In Quint, a figure at once pathetic and inspiring, the author has drawn a character whose divine charm should be felt by every reader.

\section{A WOMAN IN THE LIMELIGHT}

By Charles Gleig, Author of 'The Nancy Manœuvres.' Crown 8vo, 6s.

A Woman in the Limelight presents candidly a typical actress of the Musical Comedy Stage, treating of her career and her love affairs with a realism that is convincing, but free of offence. The heroine allures and for a long time retains the devotion and affection of a typical solitary Londoner, who is not less devoted to the bon motif; but the inevitable break occurs. There is plenty of humour and of first-hand knowledge in this study of upper Bohemian life of to-day, and the characters are vividly drawn.

\section{A WILDERNESS WOOING}

By W. Victor Cook, Author of 'Anton of the Alps.' Second Edition. Crown 8vo, 6s.

A thrilling story of the early French-Canadian pioneers, and the romantic adventures of a young heir to an English earldom. The novel, which is full of excitement and dramatic incident, presents a series of vivid pictures of the days when the great pathfinder La Salle was carrying the lilies of France at utmost hazard into the Western wilds. The love interest is strong, and attractively handled, and even such strange-seeming affairs as the 'Ship of Women' and the marriage market at Quebec have their historical sanction.

\section{NANGE OF MANCHESTER}

By Orme Agnus, Author of 'Sarah Tuldon's Lovers.' Second Edition. Crown 8vo, 6s. 
Dr. Anthony Belton called Nance 'the bravest girl in Manchester,' and he was a good judge. She assumed maternal cares at an early age, and she lived for her children. Later she took up her residence in the South of England with Mrs. Nolliver, and there struck up a friendship with Miss Denise Martayne, a lady whose gifts had put her in an exalted if not a happy position. It was a friendship that dispelled gloom and created happiness. 'Nance of Manchester' is a tribute to the omnipotence of love.

\section{HONOURS EASY}

\section{By Mrs. J. O. ARnold, Author of 'The Fiddler.' Crown 8vo, 6s.}

The interest of this story centres in the will of a Professor Clifford, in which a large sum of money is left to the scientist who shall within a specified time finish the testator's life research. Failing its completion the money is to revert to his stepdaughter. Humpbrey Wyatt undertakes the task, incidentally falling in love with the stepdaughter, of whose relationship to the Professor he is unaware. What happens before and after he discovers her identity makes a charming romantic ending to the book.

\section{THE OAKUM PIGKERS}

By L. S. Gibson, Author of 'The Ships of Desire.' Second Edition. Crown 8vo, 6s.

A story treating of modern social life, and incidentally of the hardships inflicted by certain phases of the Divorce Laws upon the innocent partner in an unhappy marriage. The two very dissimilar women are well delineated and contrasted. Cynthia and Elizabeth, each in her own way, are so human and sympathetic that the reader can hardly fail to endorse the quotation on the title-page, 'I do not blame such women, but for love they pick much oakum.' The men are drawn with no less strength and sincerity; while Lady Juliet-the brilliant, heartless, little mondaine who precipitates the tragedy of three lives-is a thumb-nail sketch of a fascinating, if worthless, type.

\section{HER SERENE HIGHNESS}

\section{By Philip laurence Oliphant. Crown 8vo, 6s.}

Disillusioned, and disgusted with Western civilization, the hero of this story, a man of remarkable force and quality, turns to the ideals of the East, becomes to all intents an Oriental, and makes for himself a great position as the white ruler of a black people in Central India. His wife deserted him in early life under a misunderstanding, goes in search of him, and finding him at last, throws in ber lot with his, and succeeds in winning him back; but not until through jealousy and other passions, he is forced to witness the sacrifice of his power and fly for very life.

\section{IT HAPPENED IN SMYRNA}

\section{By Thomas Edgelow. Crown 8vo, 6s.}

A vivid record of Eastern travel and adventure by a new author. The story opens on a German liner off the East African coast, and 
leads us via Port Said to Smyrna. There and in the interior of Turkey-in-Asia are laid the scenes of Tony Paynter's adventures. It is in the Smyrna bazaars that he and Sylvia Sayers first encounter the Turk who is destined to play so important a role in their two lives, and it is from Smyrna that, at last, they sail away when all has happily ended.

\section{BETTY HARRIS}

By Jennette Lee, Author of 'Uncle William' and 'Happy Island.' Crown 8vo, 3s. 6d.

Betty Harris, the only child of an American millionaire, strays one day into the shop of a Greek fruit-dealer, Achilles Alexandrakis, and watches the flight of a butterfly that the Greek liberates from its grey cocoon. The story is of the friendship that grew out of this meeting, and a rescue that grew out of the friendship. This blend of the spirit of the old world and the new, meeting in the grimy Chicago shop and finding out their need of each other, gives the book a piquancy.

\section{GHARLES THE GREAT}

By Mrs. H. H. Penrose, Author of 'The Sheltered Woman,' etc. Crown 8vo, 6s.

Charles the Great is a very light comedy, and it therefore counts as a new departure for Mrs. H. H. Penrose. Those who like their fiction to provide them with 'a good laugh' will doubtless prefer this book, which is packed from cover to cover with mirth-provoking material, to those other books by the same autbor, in which humour acts chiefly as train-bearer to tragedy. The determination of Charles to invent for himself a greatness which he is incapable of otherwise achieving, and its effect on his circle of intimates, are set forth in an exceedingly lively story, the plot of which it would be unfair to give away.

\section{THE AGE OF HEARTS}

By C. Thomas-Stanford. Crown 8vo, $6 \mathrm{~s}$.

An English Member of Parliament, spending a holiday in the Portuguese island of Madeira in January 1912, becomes unwittingly privy to a plot against the Republican Government. The conspirators, fearful that he will betray their secrets, make him prisoner; but he escapes to experience a series of adventures on the rugged coast, and amid the wild mountains of the island. Throngh the tangled web of plot and counterplot runs the thread of a love story.

\section{LYNETTE}

By John Overton. Crown 8vo, $6 s$.

Although Lynette, by a new writer, does not claim to be an historical novel, it is based on facts connected with the struggle between the Cavaliers and Roundheads, and is a wholesome story of love and adventure, of hard fighting and high ideals. 



\section{COLONIAL BOOK SERVICE 45 FOURTH AVE. \\ New York City 3. GRamercy 5-8354 \\ Wo Hunt Out-of-Print Books}




\section{Date Due}

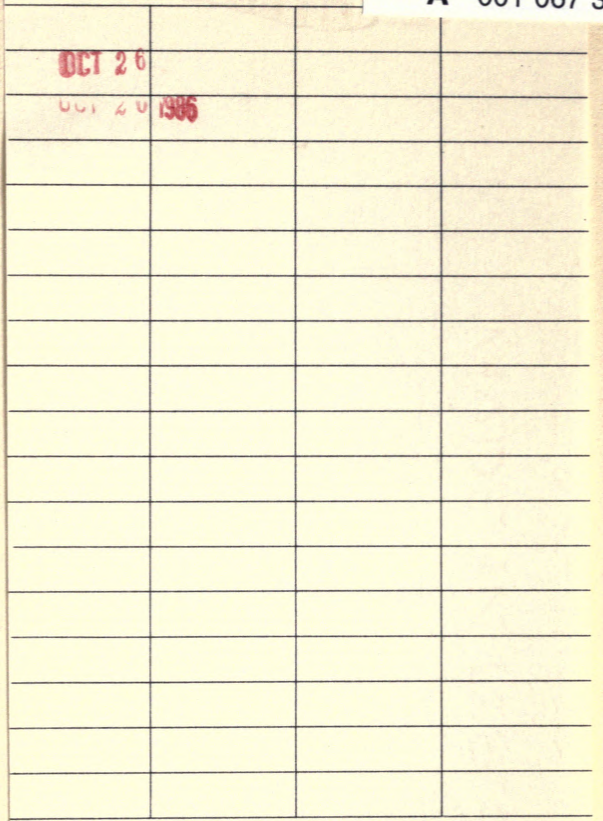


